436

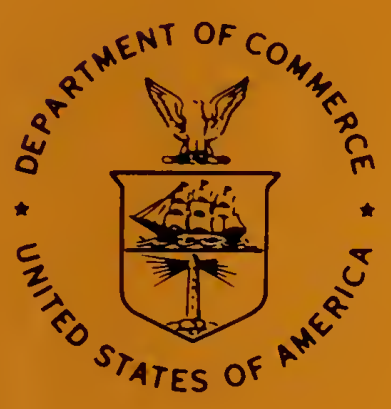

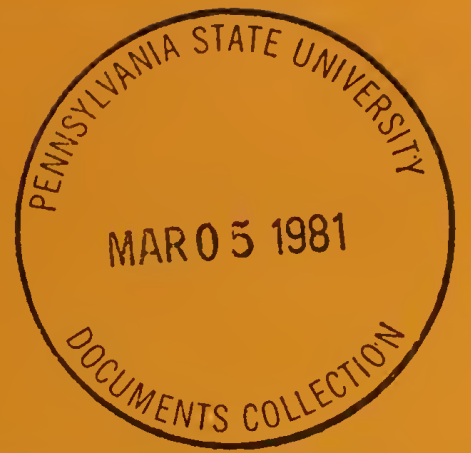

NOAA Technical Report NMFS Circular 436

\title{
Synopsis of Biological Data on Frigate Tuna, Auxis thazard, and Bullet Tuna, $A$. rochei
}

January 1981

FAO Fisheries

Synopsis No. 124

NMFS/S 124

SASTT - Auxis rochei: $1.75(01) 023.03$ Auxis thazard: $1,75(01) 023,01$

U.S. DEPARTMENT OF COMMERCE National Oceanic and Atmospheric Administration National Marine Fisheries Service 


\title{
NOAA TECHNICAL REPORTS
}

\section{National Marine Fisheries Service, Circulars}

\begin{abstract}
The major responsibilities of the National Marine Fisheries Service (NMFS) are to monitor and assess the abundance and geographic distribution of fishery resources, to understand and predict fluctuations in the quantity and distribution of these resources, and to establish levels for optimum use of the resources. NMFS is also charged with the development and implementation of policies for managing national fishing grounds, development and enforcement of domestic fisheries regulations, surveillance of foreign fishing off United States coastal waters, and the development and enforcement of international fishery agreements and policies. NMFS also assists the fishing industry through marketing service and economic analysis programs, and mortgage insurance and vessel construction subsidies. It collects, analyzes, and publishes statistics on various phases of the industry.

The NOAA Technical Report NMFS Circular series continues a series that has been in existence since 1941. The Circulars are technical publications of general interest intended to aid conservation and management. Publications that review in considerable detail and at a high technical level certain broad areas of research appear in this series. Technical papers originating in economics studies and from management investigations appear in the Circular series.

NOAA Technical Report NMFS Circulars are available free in limited numbers to governmental agencies, both Federal and State. They are also available in exchange for other scientific and technical publications in the marine sciences. Individual copies may be obtained (unless otherwise noted) from D822, User Services Branch, Environmental Science Information Center, NOAA, Rockville, MD 20852. Recent Circulars are:
\end{abstract}

\begin{abstract}
396. Whales, dolphins, and porpoises of the western North Atlantic. A guide to their identification. By Stephen Leatherwood, David K. Caldwell, and Howard E. Winn. August 1976, iv + 176 p., 168 figs., 1 table, 14 app. figs. For sale by the Superintendent of Documents, U.S. Government Printing Office, Washington, DC 20402; Stock No. 003-02000119-0.
\end{abstract}

397. Marine flora and fauna of the northeastern United States. Cnidaria: Scyphozoa. By Ronald J. Larson. August 1976, iii +18 p., 28 figs. For sale by the Superintendent of Documents, U.S. Government Printing Office, Washington, DC 20402; No. 003-01700387.

398. Marine flora and fauna of the northeastern United States. Higher fungi: Ascomycetes, Deuteromycetes, and Basidiomycetes. By A. R. Cavaliere. March 1977, iii +49 p., 24 figs. For sale by the Superintendent of Documents, U.S. Government Printing Office, Washington, DC 20402; Stock No. 003-020-00126-2.

399. Marine flora and fauna of the northeastern United States. Copepoda: Harpacticoida. By Bruce C. Coull. March 1977, iii +48 p., 100 figs. For sale by the Superintendent of Documents, U.S. Government Printing Office, Washington, DC 20402; Stock No. 003-020-00125 4

400. Fishery publication index, 1965-74. By Mary Ellen Engett and Lee C. Thorson. March 1977, iii +220 p. For sale by the Superintendent of Documents, U.S. Government Printing Office, Washington, DC 20402; Stock No. 003-020-00127-1.

401. Fisheries and fishery resources of New York Bight. By J. L. McHugh. March 1977, v +50 p., 43 figs., 49 tables. For sale by the Superintendent of Documents, U.S. Government Printing Office, Washington, DC 20402; Stock No. 003-020-00129-7.

402. Guide to the identification of scorpionfish larvae (Family Scorpaenidae) in the eastern Pacific with comparative notes on species of Sebastes and Helicolenus from other oceans. By H. Geoffrey Moser, Elbert H. Ahlstrom, and Elaine M. Sandknop. April 1977, v + 71 p., 40 figs., 38 tables. For sale by the Superintendent of Documents, U.S. Government Printing Office, Washington, DC 20402; Stock No. 003-02000128-9.

403. Marine flora and fauna of the northeastern United States. Sipuncula. By Edward B. Cutler. July 1977 , iii +7 p., 6 figs. For sale by the Superintendent of Documents, U.S. Government Printing Office, Washington, DC 20402; Stock No. 003-012-00404-0.

404. Revision of the sea basses of the genus Diplectrum (Pisces: Serranidae). By Stephen A. Bortone. September 1977, v + 49 p., 15 figs., 9 tables.

405. Marine flora and fauna of the northeastern United States. Echinodermata: Holothuroidea. By David L. Pawson. September 1977, iii + 15 p., 3 figs. For sale by the Superintendent of Documents, U.S. Gov- ernment Printing Office, Washington, DC 20402; Stock No. 003-0170040-4.

406. Marine flora and fauna of the northeastern United States. Copepoda: Lernaeopodidae and Sphyriidae. By Ju-Shey Ho. December 1977 , iii +14 p., 16 figs. For sale by the Superintendent of Documents, U.S. Government Printing Office, Washington, DC 20402; Stock No. 003-017-00412-1.

407. Distribution of decapod Crustacea off northeastern United States based on specimens at the Northeast Fisheries Center, Woods Hole, Massachusetts. By Austin B. Williams and Roland L. Wigley. December 1977 , iii +44 p., 2 figs., 1 table, 57 charts.

408. Collection of tuna baitfish papers. (20 papers.) By Richard S. Shomura (editor). December 1977, iii + $167 \mathrm{p}$.

409. Marine flora and fauna of the northeastern United States. Copepoda: Cyclopoids parasitic on fishes. By Ju-Shey Ho. February 1978, iii +12 p., 17 figs.

410. The 1976 Ceratium tripos blonm in the New York Bight: Causes and consequences. By Thomas C. Malone. May 1978, iv + 14 p., 17 figs., 1 table.

411. Systematics and biology of the tilefishes (Perciformes: Branchiostegidae and Malacanthidae), with descriptions of two new species. By James K. Dooley. April 1978, v + 78 p., 44 figs., 26 tables.

412. Synopsis of biological data on the red porgy, Pagrus pagrus (Linnaeus). By Charles S. Manooch III and William W. Hassler. May 1978, iii +19 p., 12 figs., 7 tables. For sale by the Superintendent of Documents, U.S. Government Printing Office, Washington, DC 20402; Stock No. 003-017-00418-0.

413. Marine flora and fauna of the northeastern United States. Crustacea: Branchiura. By Roger F. Cressey. May 1978, iii + 10 p., 15 figs. For sale by the Superintendent of Documents, U.S. Government Printing Office, Washington, DC 20402; Stock No. 003-017-00419-8.

414. Synopsis of biological data for the winter flounder, Pseudopleuronectes americanus (Walbaum). By Grace Klein-MacPhee. November 1978, iii +43 p., 21 figs., 28 tables.

415. A basis for classifying western Atlantic Sciaenidae (Teleastei: Perciformes). By Labbish Ning Chao. September 1978, v + 64 p., 41 figs., 1 table.

416. Ocean variability: Effects on U.S. marine fishery resources 1975. (20 papers.) By Julien R. Goulet, Jr. and Elizabeth D. Haynes, Editors. December 1978, iii $+350 \mathrm{p}$.

417. Guide to the identification of genera of the fish Order Ophidiiformes with a tentative classification of the order. By Daniel M. Cohen and Jørgen G. Nielsen. December 1978, vii +72 p., 103 figs., 2 tables. 
NOAA Technical Report NMFS Circular 436

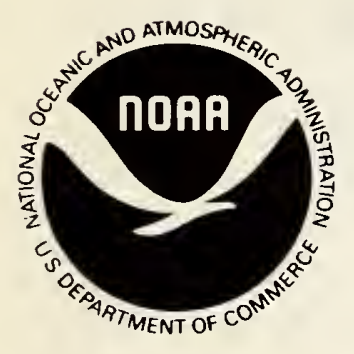

\author{
Synopsis of \\ Biological Data on \\ Frigate Tuna, Auxis thazard, \\ and Bullet Tuna, A. rochei
}

Richard N. Uchida

January 1981

FAO Fisheries Synopsis No. 124

U.S. DEPARTMENT OF COMMERCE

Philip M. Klutznick, Secretary

National Oceanic and Atmospheric Administration

Richard A. Frank, Administrator

National Marine Fisheries Service

Terry L. Leitzell, Assistant Administrator for Fisheries 
The National Marine Fisheries Service (NMFS) does not approve, recommend or endorse any proprietary product or proprietary material mentioned in this publication. No reference shall be made to NMFS, or to this publication furnished by NMFS, in any advertising or sales promotion which would indicate or imply that NMFS approves, recommends or endorses any proprietary product or proprietary material mentioned herein, or which has as its purpose an intent to cause directly or indirectly the advertised product to be used or purchased because of this NMFS publication. 


\section{CONTENTS}

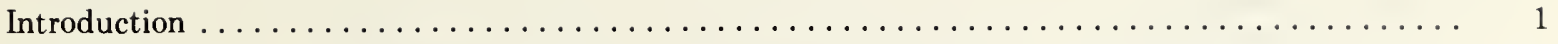

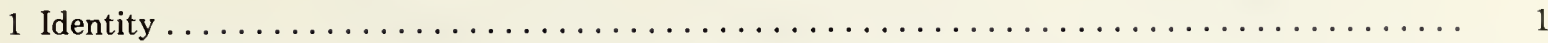

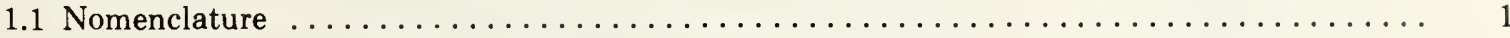

*1.11 Valid

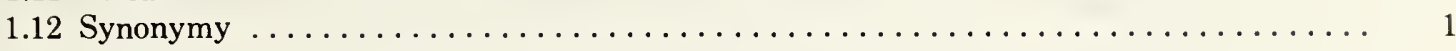

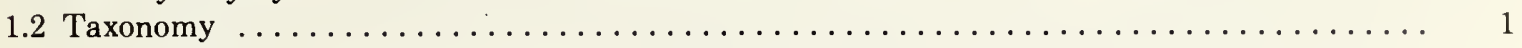

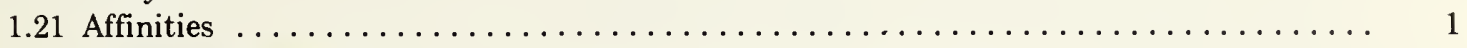

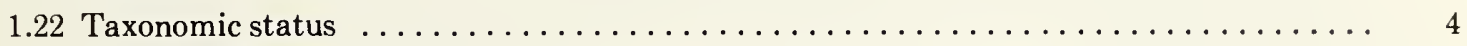

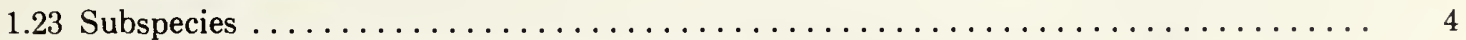

1.24 Standard common names, vernacular names $\ldots \ldots \ldots \ldots \ldots \ldots$

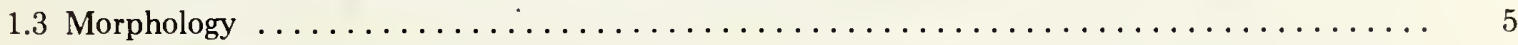

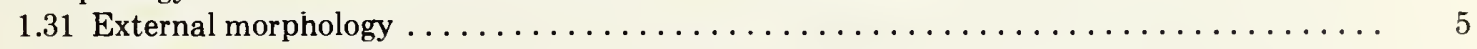

*1.32 Cytomorphology

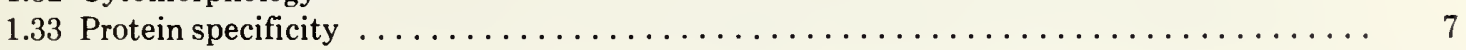

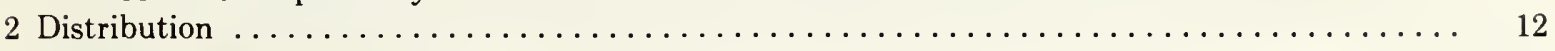

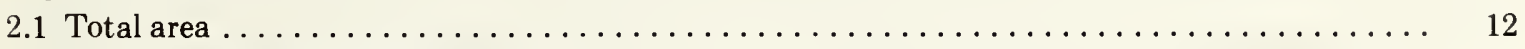

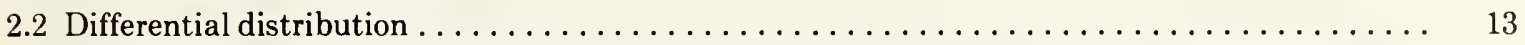

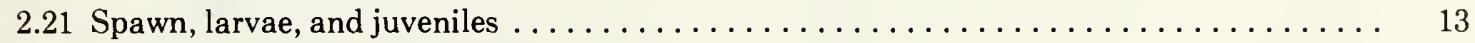

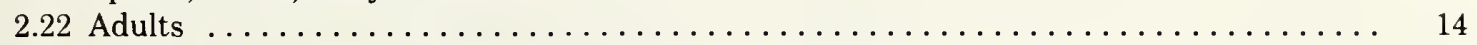

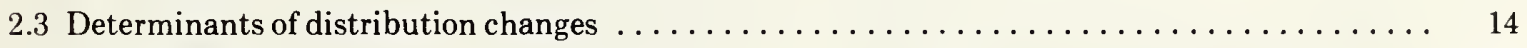

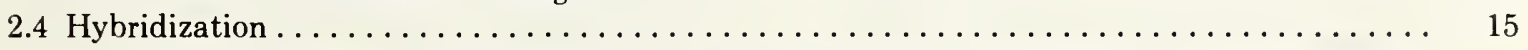

2.41 Hybrids; frequency of hybridization, species with which hybridization occurs; methods of hybridization

*2.42 Influence of natural hybridization in ecology and morphology

3 Bionomics and life history

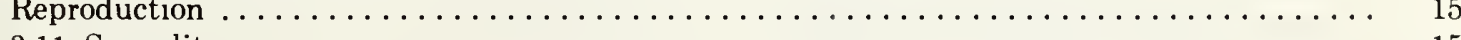

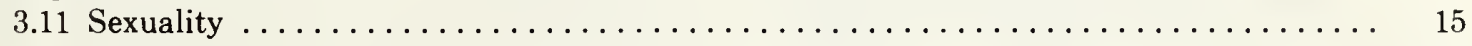

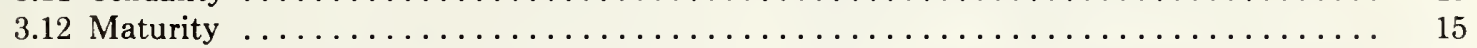

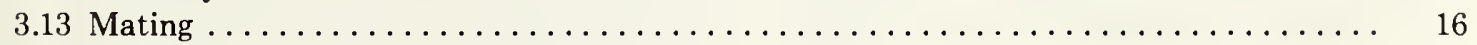

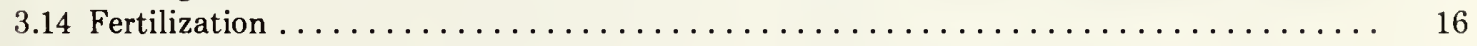

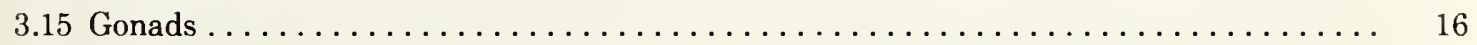

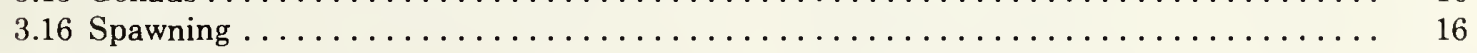

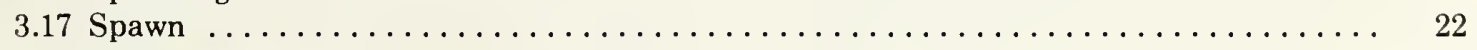

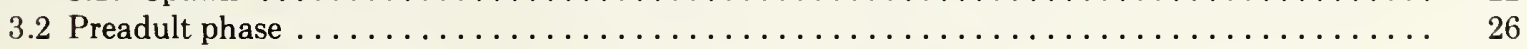

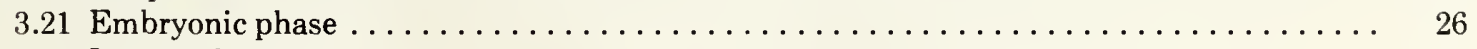

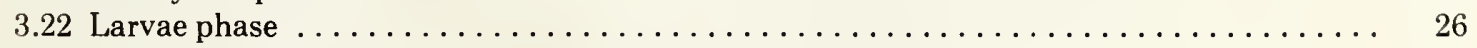

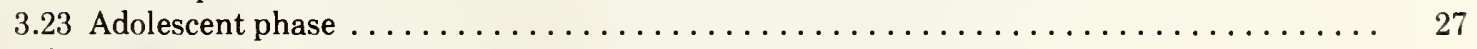

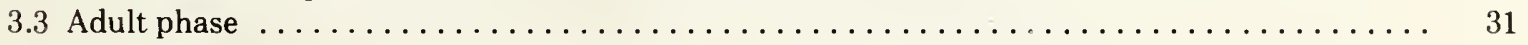

*3.31 Longevity

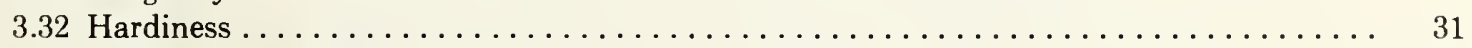

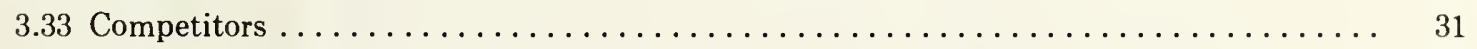

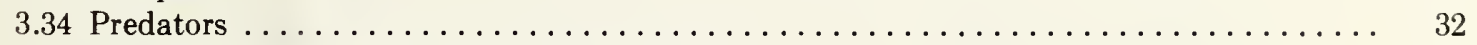

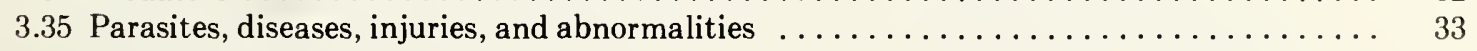

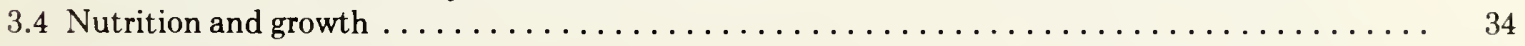

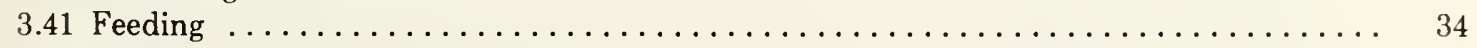

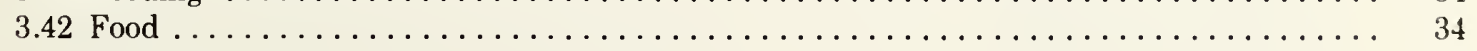

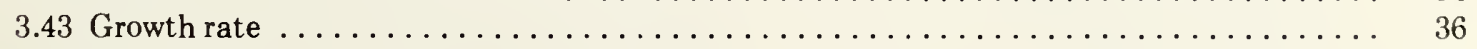

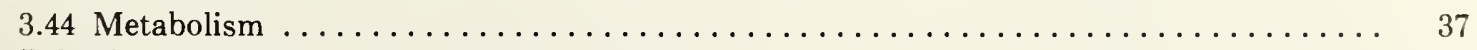

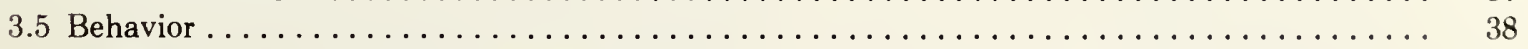

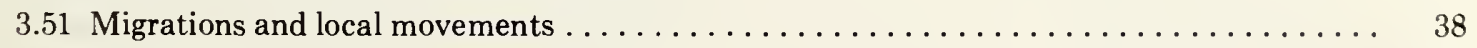

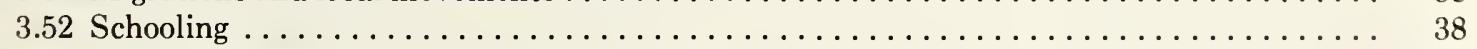

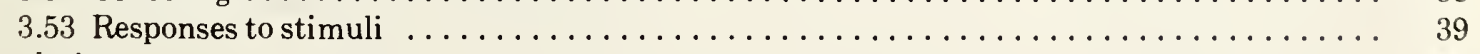

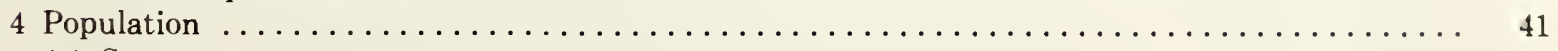

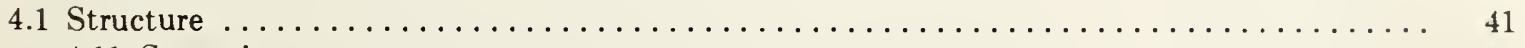

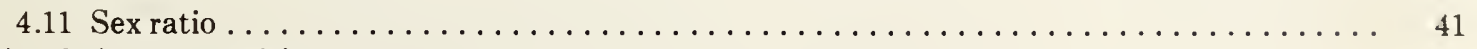

*4.12 Age composition

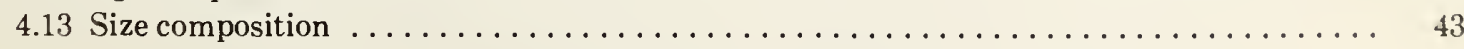




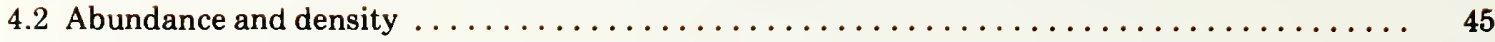

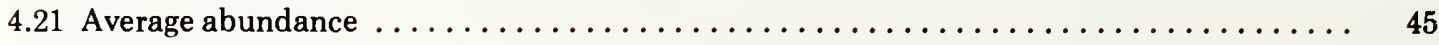

*4.22 Changes in abundance

*4.23 Average density

*4.24 Changes in density

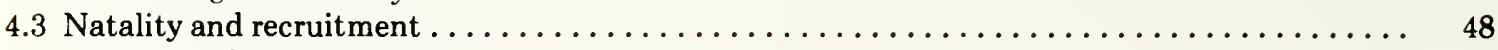

4.31 Reproduction rates $\ldots \ldots \ldots \ldots \ldots \ldots \ldots \ldots \ldots \ldots \ldots \ldots \ldots \ldots \ldots \ldots \ldots$

*4.32 Factors affecting reproduction

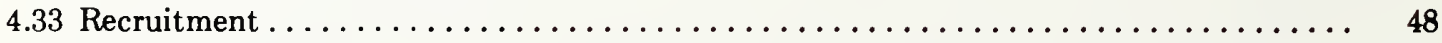

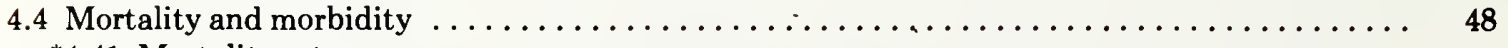

*4.41 Mortality rates

4.42 Factors causing or affecting mortality $\ldots \ldots \ldots \ldots \ldots \ldots \ldots \ldots \ldots \ldots \ldots \ldots \ldots$

*4.43 Factors affecting morbidity

*4.44 Relation of morbidity to mortality rates

*4.5 Dynamics of population

*4.6 The population in the community and the ecosystem

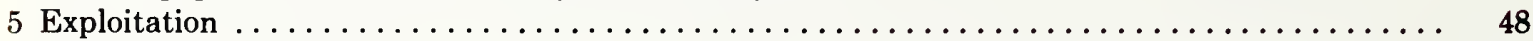

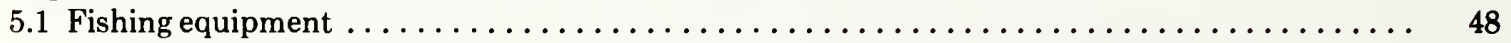

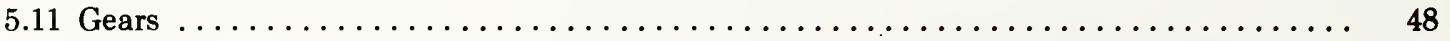

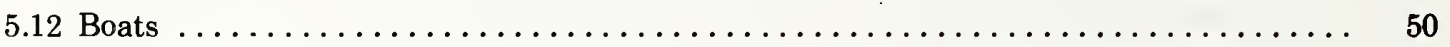

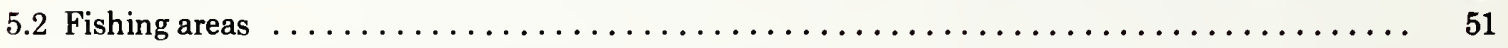

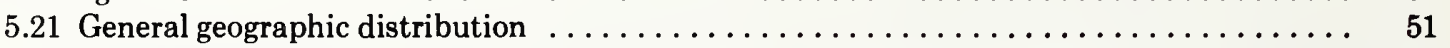

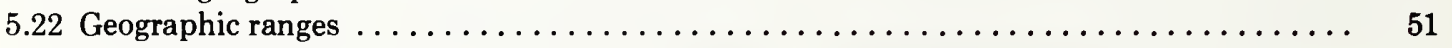

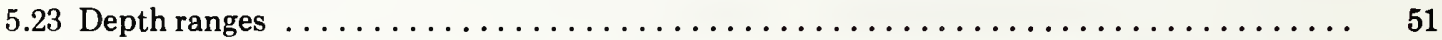

*5.24 Conditions of the grounds

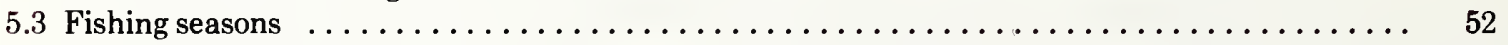

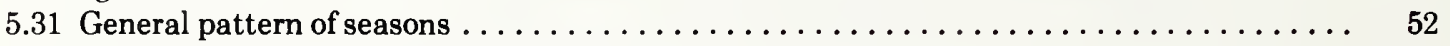

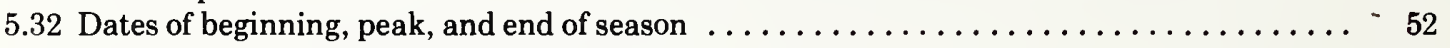

5.33 Variation in date or duration of season $\ldots \ldots \ldots \ldots \ldots \ldots \ldots \ldots \ldots \ldots \ldots \ldots \ldots \ldots \ldots \ldots \ldots$

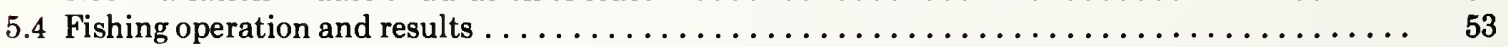

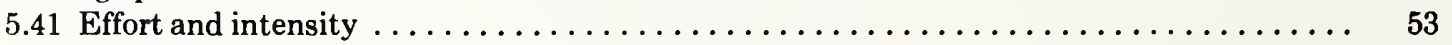

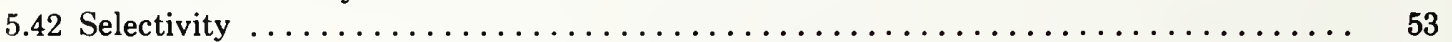

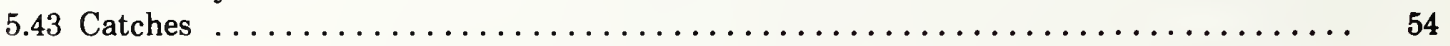

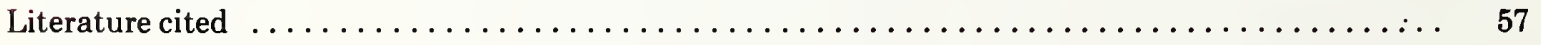

${ }^{*}$ No information available. 


\title{
Synopsis of Biological Data On Frigate Tuna, Auxis thazard, and Bullet Tuna, A. rochei
}

\author{
Richard N. Uchida ${ }^{1}$
}

\begin{abstract}
This synopsis of biological and technical data on frigate tuna, Auxis thazard, and bullet tuna, A. rochei, includes information on identity, distribution, bionomics, life history, population, and exploitation. Over 200 published and unpublished reports, up to and including those published in 1978 , are covered.
\end{abstract}

\section{INTRODUCTION}

Unlike a number of tuna species in the world's oceans which are heavily exploited and possibly are being harvested near the upper limit of rational utilization, frigate mackerels (or frigate and bullet tunas; see Klawe 1977), the most primitive genus of the higher tunas (tribe Thunnini), give every indication of being an underutilized fishery resource. In planning for the rational utilization of this resource, it is imperative to have on hand information concerning the biology of the species and estimates of present and potential catches. The purposes of this paper, therefore, are to update our current knowledge of the species by bringing together and abstracting all the available information on the biology and fisheries for frigate and bullet tunas and to review and evaluate in depth the results of past research, indicating in particular where conflicting evidence exists.

\section{IDENTITY}

\subsection{Nomenclature}

Auxis thazard (Lacepède) 1802

Auxis rochei (Risso) 1810

\subsection{Synonymy}

It it not possible at this time to assign all the various names that have appeared in the literature to either thazard or rochei. The following names are from Rosa (1950), de Beaufort and Chapman (1951), Collingnon $(1960),{ }^{2}$ Williams (1963), ${ }^{3}$ Idyll and de Sylva (1963), and Jones (1963) and are listed in chronological order.

'Southwest Fisheries Center, National Marine Fisheries Service, NOAA, P.O. Box 3830, Honolulu, HI 96812.

${ }^{2}$ Collingnon, J. 1960, Report on Auxis thazard in the eastern Atlantic. [In Fr.] CCTA Symposium on Thunnidae, Dakar, 12-27 December 1960, 5 p. (Mimeogr.) (Engl. transl. available Southwest Fish. Cent., Natl. Mar. Fish. Serv., NOAA, Honolulu, HI 96812.)

${ }^{3}$ Williams, F. 1960. A symposium of existing knowledge on the fishes on the genus Auxis Cuvier, 1829 in the Indian Ocean. CCTA
Scomber thazard Lacepède 1802 (original description; off coast of New Guinea)

Scomber bisus Rafinesque 1810 (original description; Palermo)

Thynnus rocheanus Risso 1826 (original description; Nice)

Auxis taso Cuvier and Valenciennes 1831 (original description; New Guinea)

Auxis vulgaris Cuvier and Valenciennes 1831 (original description; Mediterranean)

Auxis tapeinosoma Bleeker 1854 (original description; Japan)

Auxis thynnoides Bleeker 1855 (original description; Ternate)

Auxis rochei. Günther 1860

Auxis thazard. Jordan and Evermann 1896

Auxis hira Kishinouye 1915 (original description; Japan) Auxis maru Kishinouye 1915 (original description; Japan) Auxis bisus. Cadenat 1950

\subsection{Taxonomy}

1.21 Affinities

Kingdom Animalia

Phylum Chordata

Subphylum Vertebrata

Superclass Gnathostomata

Class Osteichthyes

Subclass Actinopterygii

Division Teleostei

Cohort Acanthopterygii

Order Perciformes

Suborder Scombroidei

Family Scombridae

Subfamily Scombrinae

Tribe Tunnini

(Thunnus, Katsuwonus,

Euthynnus, Auxis)

Symposium on Thunnidae, Dakar, 12-27 December 1960, $13 \mathrm{p}$. (Mimeogr.) 
Genus Auxis Cuvier 1829 (type-species: Scomber rochei Risso) by subsequent selection by Gill (1862).

The description of the genus Auxis under "Les Scombres" first appeared in Cuvier's Règne Animal in 1829. From the time of Cuvier's work to the present, however, the genus Auxis has had several reclassifications. For example, in classifying the genus Auxis, Kishinouye (1915) first included it in the family Thunnidae. However, in a later work (1917), he placed Thunnidae and Katsuwonidae in a new order called Plecostei and placed the families Scombridae and Cybiidae in the order Teleostei. The genus Thunnus fell under Thunnidae and the genera Katsuwonus, Euthynnus, and Auxis came under Katsuwonidae (Kishinouye 1923). The primary characteristic subcutaneous blood vessels; a secondary characteristic of Plecostei was the presence of well-developed subcutaneous blood vessels; a secondary characteristic was the development of dark red lateral tissues in relation to the subcutaneous blood vessels.

Many scientists disagreed with Kishinouye's new order and its subdivision. Takahashi (1924) argued that Plecostei was established only on partial differences in the highly variable vascular system and cannot exist on an equal status with the other four orders of Teleostomi. Jordan (1923) and Herre (1953) placed the scombroid fishes in two families-Scombridae and Thunnidae. Fraser-Brunner (1950), on the other hand, rejected any division of the family Scombridae arguing that attempts to subdivide this family "have resulted in arrangements which are artificial and have left the classification in an uneasy, shifting state." de Sylva (1955), Collette and Gibbs (1963b), and most other recent workers recognize a single family Scombridae with various subdivisions. Collette and Chao (1975) placed Auxis in the tribe Thunnini of the subfamily Scombrinae

The following description of the genus Auxis is from Jordan and Evermann (1905): "Body oblong, plump, most naked posteriorly, anteriorly covered with small scales, those of the pectoral region enlarged, forming a corselet; snout very short, conical, scarcely compressed; mouth rather small, the jaws equal; teeth very small, mostly in a single series, on the jaws only; tail very slender, depressed, with a rather large keel on each side; first dorsal short, separated from the second by a considerable interspace; second dorsal and anal small, each with 7 or 8 finlets; pectorals and ventrals small; no airbladder; branchiostegals 7 ; pyloric coeca dentritical; gillrakers very long and slender, numerous; vertebrae 39 in number, peculiarly modified ....."

Auxis is the most primitive genus among the higher tunas that have developed a prootic pit and a partial subcutaneous circulatory system (Collette and Gibbs 1963b). All the Thunnini, except Auxis, have a common cutaneous artery that divides into dorsal and ventral branches lateral to the aorta; in A uxis, however, the dorsal and ventral branches originate separately with the latter being very poorly developed (Collette 1978). The haemal spines of the thoracic vertebrae do not form a haemal arch and the first vertebra is not sutured to the cranium as in the higher members of Thunnini. Also, compared with Euthynnus, Katsuwonus, and Thunnus, Auxis lacks the frontoparietal fenestra, which is an additional pair of openings present in the cranium and has a lateral countercurrent system for heat exchange that is not as well developed phylogenetically (Collette 1978). All members of the tribe Thunnini have a swim bladder as juveniles; however, the bladder degenerate with growth in Auxis, Euthynnus, and Katsuwonus.

Several other characters distinguish members of the genus Auxis, the smallest of the higher tunas, from other scombrids (Collette and Gibbs 1963b; Fitch and Roedel 1963; Williams 1963). In Auxis, there is a single interpelvic process which is between and about as long as the pelvic fins. In other tunas, but not in other scombrids, the interpelvic process is bifurcate and much less than half the length of the pelvic fins (it is single but small in Grammatorcynus and Gymnosarda). The number of dorsal and anal finlets (seven or eight) distinguishes Auxis from Scomber, which has only five of each. Auxis can also be distinguished from Rastrelliger by the lack of a corselet and a body entirely covered with moderate-sized scales in the latter.

\section{Species - Auxis thazard (Lacepède) 1802}

The following description of $A$. thazard (Fig. 1, upper photo) is from Williams (1963). Major morphological features described under the genus are omitted from the account of the species.

"Depth 3.9 to 4.5 , head 3.2 to 3.8 in standard length. Eye 5.0 to 5.85 in head, 1.25 to 1.66 in snout and 1.25 to 1.7 in the flatly rounded interorbital space. Snout 3.62 to 4 in head. Maxilla reaches to a point under the anterior half of the eye and is 3 in head. Single row of small pointed teeth in each jaw, none on palate. Jaws almost equal. First and second dorsal spines subequal, equal to snout and eye; following spines rapidly decreasing in size, eighth usually shorter than the pupil. Second dorsal fin very low, about three times its base distant from first dorsal; first ray of second dorsal about 5 in head. Anal similar to second dorsal, first ray about 5.2 in head. Pectorals short, roughly triangular, about 2 in head and shorter than postorbital; origin of pectoral before that of first dorsal. Pelvics thoracic, about 2.5 in head, origin somewhat behind that of pectorals. Caudal lunate, upper lobe about 1.8 in head. Body naked except for the corselet of scales anteriorly. Rear margin of the corselet runs from base of second dorsal to above end of pectoral; thence there is a posterior prolongation of the corselet along the lateral line; below the pectoral tips the corselet margin curves to above the pelvic base from where it turns posteriorly and finishes well behind the tips of the pelvics. The prolongation of the corselet along the lateral line tapers abruptly between first and second dorsal fins, and under the origin of the second dorsal is not more than 4 irregular scale rows wide. Scales large and imbricated above pectoral base. Gill rakers about 1.75 in length of gill filaments." 


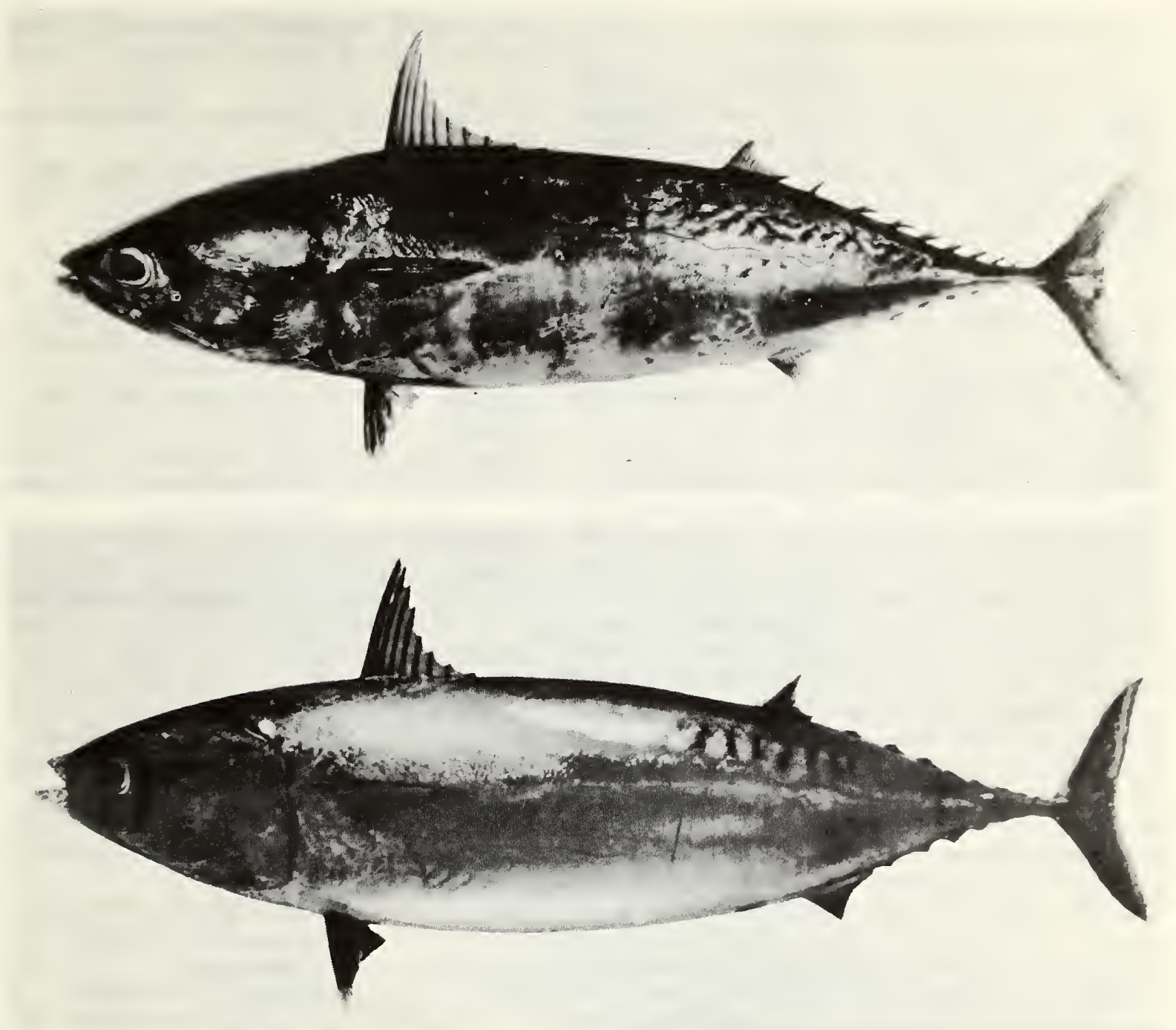

Figure 1.-Auxis thazard (upper photo) from the eastern Pacific, collected at Morgan Bank, Baja California, and A. rochei (lower photo) from near Santa Catalina Island, Calif. (Fitch and Roedel 1963)

\section{Species - Auxis rochei (Risso) 1810}

The description of $A$. rochei (Fig. 1, lower photo) is from Jones (1958), who originally referred to the specimen as $A$. tapeinosoma.

"Body robust, rounded, almost circular in crosssection. Dorsal outline moderately and evenly curved. Ventral outline evenly curved when fresh but slightly flattened abdominally after preservation in formalin.

"Height 5.38 in standard and 5.55 in furcal [= fork] length. Head 3.77 in standard and 3.88 in furcal length. Snout, pointed 3.9 in the head, longer than eye diameter. Eye 4.91 in the head, 1.27 in the snout, 1.27 in the almost flattened interorbital space. Mouth moderate, oblique, end of maxillary reaching vertical from anterior margin of eye. Jaws nearly equal, the lower jaw projecting almost imperceptibly beyond the upper. Teeth small, pointed in a single row on both jaws, none on palate. Branchiostegals 7. Gill rakers long and slender, 45 in first gill arch.

"Two dorsal fins separated by interspace slightly shorter than head length. First dorsal roughly triangular with 10 spines, anterior spine longest. Second dorsal small with 13 rays. Dorsal finlets 8 . Anal fin small, with 2 spines, 11 rays. Anal finlets 7 . Pectorals roughly triangular, reaching vertical from the base of first ray of first dorsal. Ventral thoracic, axillary scales equal in length to ventrals.

"Body naked except for the corselet of scales which taper gradually to 9-10 irregular scale rows at vertical through second dorsal and end as a narrow line at vertical below second dorsal finlet. Scales large and imbricated above pectoral base. Caudal peduncle slender with feebly developed lateral keels. Lateral line somewhat undulating and without a distinct arch." 


\subsection{Taxonomic status}

A specimen of frigate tuna, collected by Commerson off New Guinea in 1768, was first described by Lacepède in 1802 as Scomber thazard. In 1810, Risso and Rafinesque, working independently, named the Mediterranean form Scomber rochei and Scomber bisus, respectively. Gill (1862) subsequently designated rochei as the typespecies for Auxis Cuvier. Systematists generally followed Günther (1860) and Jordan and Gilbert (1882) in using Risso's rochei instead of Rafinesque's bisus, but no one has indicated which name was described first. Furthermore, the International Commission of Zoological Nomenclature has never ruled as to which name, rochei or bisus, is valid (Fitch and Roedel 1963).

Over the years, other names appeared in the literature. These include Thynnus rocheanus Risso, 1826 (Mediterranean), A. vulgaris Cuvier and Valenciennes, 1831 (Mediterranean), A. taso Cuvier and Valenciennes, 1831 (New Guinea), A. tapeinosoma Bleeker, 1854 (Japan), and $A$. thynnoides Bleeker, 1855 (Ternate). In 1915, Kishinouye described two additional names. The species he named hira had a short corselet which ended slightly posterior to the pectoral fin. The other he named maru had a long corselet which extended to the anal fin. Kishinouye stated that the maru is probably the same species as thazard, but could not say whether thazard corresponded to hira or maru. Furthermore, he believed that Bleeker's (1854) tapeinosoma could be maru, but the figure and description of this species were unclear and he was unable to make a positive identification. Therefore, Kishinouye described them as new species, hira and maru.

Fraser-Brunner (1950) disagreed with Kishinouye and recognized only a single, worldwide species, thazard, but others, such as Wade (1949), Cadenat (1950), and Jones (1958), recognized two species of Auxis. Wade (1949) used Bleeker's name tapeinosoma for a long-corseletted pacific form. Matsumoto (1959, 1960a), on the other hand, finding the nomenclature of the long-corseletted form confused, resurrected the name thynnoides. He argued that tapeinosoma of Wade (1949) and Herre and Herald (1951) appeared to be a misnomer because it is actually a short-corseletted form. Furthermore, Matsumoto regarded hira and maru of Kishinouye and tapeinosoma of Bleeker as synonyms of the short-corseletted, worldwide thazard.

\subsection{Subspecies}

None.

1.24 The standard common names, vernacular names

The standard common names and vernacular names of A. thazard were abstracted from the lists published in Fiedler (1945), Rosa (1950), Collingnon (1960 -see footnote 2), FAO (1960, 1976), Idyll and de Sylva (1963), Uchida (1963), Williams (1963), Instituto del mar del
Peru (19714), Miyake and Hayasi (1972), Klawe (1977), and Roberts et al. (1977).

\section{Country Common and vernacular names}

Algeria
Angola
Australia
Brazil
British Guiana
British West
$\quad$ Indies
Canada
Denmark
East Africa

Auxide, Scunno, Bisu, Melva, Melvara

Jedeu

Frigate mackerel, Leadenall

Bonito cachorro

Frigate mackerel, Blowgoat

Frigate mackerel, Blowgoat, Roundbelly bonito

Frigate mackerel, Thazard

Auxide

Frigate mackerel, Sehewa (Kiswahili) also refers to Euthynnus and Katsuwonus sp.

Ecuador
France

Botellita

French Morocco Melva

Auxide, Bonitou, Bounitou, Bounicou, Palamida, Auxide bise, Tazard, Bizet

French West Melva

Africa

Ghana

Gold Coast

Greece

Haiti

Hawaiian Islands

India

Israel

Italy

\section{Okpopu, Odaabi, Poku-poku}

Frigate mackerel

Kopáni

Maquereau

Frigate mackerel, Keokeo, Mexican skipjack

Frigate mackerel, Churai, Urulanchurai, Kutteli-churai (Tamil)

Tuna nanasit

Strumbo, Tambarello, Strombo, Scurmo, Tombarello, Tamburella, Tambarella, Sgionfetta, Tumbarel, Bisu, M'pisu, Pisantuni, Mazzita, Sangulu, Culariau, Sgamiru, Tunnacchiu, Biso

Ivory Coast Boku-boku, Poku-poku, Bongu

Japan

Auxis sp. Sodagatsuwo

A. thazard $=$ Hirasōda, Hirasōdakatusuo, HirameA. hira jika, Obosogatsuwo, Shibuwa, Soma, Suma, Oboso (Hirasohda, Hiragatsuo, and Hiramedika are variations in spelling of some of the above names)

Korea

Madeira

Mul-chi-da-rae, Mul-chi, Mu-tae-daraeng, Mog-man-dung-i

Malta Island

Mexico

Chapouto

Tombrell, Mazzita, Tombitombi, Zgamirru

Bonito

\footnotetext{
"Instituto del Mar del Peru. 1971. Report of the "Instituto del mer del Peru" and other institutes of fishery investigations from South America for the fourth session of the FAO panel of experts for the facilitation of tuna research. La Jolla, Calif., 8-13 November 1971, FIR:EPFTR/71/Inf. 12, 26 p. (Mimeogr.)
} 


\begin{tabular}{|c|c|}
\hline Morocco & Melva \\
\hline New Zealand & Frigate tuna \\
\hline Norway & Auxis \\
\hline $\begin{array}{l}\text { Papua New } \\
\text { Guinea }\end{array}$ & Deho \\
\hline Peru & Melva, Macarela \\
\hline $\begin{array}{l}\text { Phillipine Is- } \\
\text { lands }\end{array}$ & $\begin{array}{l}\text { Frigate mackerel, Tunungan, Man- } \\
\text { ko, Mangko (Marinao, Samal, Vis- } \\
\text { aya, and Tao Sug) }\end{array}$ \\
\hline Portugal & $\begin{array}{l}\text { Gayado, Judea, Serra, Cachorra, Bo- } \\
\text { nito }\end{array}$ \\
\hline Sarawak & Tongkol \\
\hline Seychelles & Bonite folle \\
\hline $\begin{array}{l}\text { Somalia (Mi- } \\
\text { jurtein coast) }\end{array}$ & Tubani (Somali) \\
\hline South Africa & Frigate mackerel \\
\hline Spain & $\begin{array}{l}\text { Melva, Visol, Melvara, Bis, Bonito } \\
\text { del Norte, Macaela }\end{array}$ \\
\hline $\begin{array}{l}\text { Spanish } \\
\text { Morocco }\end{array}$ & Melva \\
\hline $\begin{array}{l}\text { Sri Lanka } \\
\quad \text { (Ceylon) }\end{array}$ & $\begin{array}{l}\text { Frigate mackerel, Rogodwa } \\
\text { (Sinhalese), Alagoduwa }\end{array}$ \\
\hline Sweden & Auxide \\
\hline Taiwan & Chien yu \\
\hline Thailand & Pla $\mathrm{O}$ \\
\hline Turkey & Gobene \\
\hline $\begin{array}{l}\text { Union of South } \\
\text { Africa }\end{array}$ & Frigate mackerel, Boo hoo \\
\hline $\begin{array}{l}\text { Union of Soviet } \\
\text { Socialist Re- } \\
\text { public }\end{array}$ & Auksida, Makrelevyi tunets \\
\hline $\begin{array}{l}\text { United King- } \\
\text { dom }\end{array}$ & Plain bonito \\
\hline Unites States & $\begin{array}{l}\text { Frigate mackerel, Bullet mackerel, } \\
\text { Boo hoo, Frigate tuna }\end{array}$ \\
\hline Venezuela & Cabaña negra \\
\hline Yugoslāvia & Trupac, Tunjcic, Rumbac \\
\hline \multicolumn{2}{|l|}{$\begin{array}{l}\text { International } \\
\text { organization }\end{array}$} \\
\hline $\begin{array}{l}\text { Food and Agri- } \\
\text { culture Organi- } \\
\text { zation of the } \\
\text { United Nations }\end{array}$ & $\begin{array}{l}\text { Frigate tuna, Auxides, Melvas } \\
\text { s (FAO) }\end{array}$ \\
\hline $\begin{array}{l}\text { International } \\
\text { Commission } \\
\text { for the Conser } \\
\text { tion of Atlanti } \\
\text { Tunas (ICCAT }\end{array}$ & Frigate tuna, Auxide, Melva \\
\hline
\end{tabular}

Jones (1963), Uchida (1963), Instituto del Mar del Peru (see footnote 4), FAO (1976), and Klawe (1977) provided the following common and vernacular names of $A$. rochei $=A$. tapeinosoma $=A$. thynnoides $=A$. maru.

\section{Country Commonand vernacular names}

Australia Long corseletted frigate mackerel, Maru frigate mackerel
Ecuador Botellita

India:

Malayalam Kuttichoora (means small tuna and (North) generally applied to $A$. thazard and young of $E$. affinis)

Malayalam Urulan-choora (means rounded tuna (South) and applied to A. thazard also from which this species is not generally distinguished)

Tamil

Japan

Peru

Union of Soviet

Socialist Re-

public

United States

Eli-choorai (means ratlike tuna), Kutteli-choorai (means small ratlike tuna)

Marusōda, Marusōdakatsuo. Marugatsuwo, Marumejika, Magatsuwo, Manba, Mandara, Chiboh, Dainanpo, Nodoguro, Rohsoku, Subota, Uzawa, Maiika, Soku, Soda, Subo. (Marumedika, Marugatsuo, Magatsuo, and Dainanbo are variations in spelling of some of the above names.) Other names mentioned by Rosa (1950) are Kogatsuo, Kukarai, Kobukura

Melva, Fragata

Skumbrievyi tunets, Auksida

Bullet mackerel, Bullet tuna

International

organization

$\begin{array}{ll}\text { FAO } & \text { Bullet tuna } \\ \text { ICCAT } & \text { Bullet tuna }\end{array}$

To avoid confusion throughout the remainder of this paper, $A$. rochei will be used instead of $A$. tapeinosoma, $A$. thynnoides, or $A$. maru to describe the long-corseletted form. For the short-corseletted form, A. thazard will be used, but there is considerable confusion in the literature because several authors used thazard in the belief that there was only a single worldwide species of Auxis (Fraser-Brunner 1950; Rivas 1951). This usage must be translated into Auxis spp. where reference is made to the Pacific forms and into $A$. rochei in the Atlantic based on Fitch and Roedel's (1963) interpretation or Auxis spp. based on Richards and Randall's (1967) documentation of $A$. thazard in the Atlantic.

\subsection{Morphology}

\subsection{External morphology}

The fin ray counts, together with the gill raker and vertebral counts, are given for $A$. thazard and $A$. rochei in Tables 1 and 2, respectively. It should be noted that some investigators did not separate the two species of Auxis at the time the meristic counts were made and, therefore, their counts have not been included.

One of the sources of confusion in identifying Auxis to 
Table 1.-Meristic characters of the short-corseletted frigate tuna, Auxis thazard, by various investigators.

\begin{tabular}{|c|c|c|c|c|c|c|c|c|}
\hline & $\begin{array}{c}\text { First } \\
\text { dorsal fin }\end{array}$ & $\begin{array}{c}\text { Second } \\
\text { dorsal fin }\end{array}$ & $\begin{array}{l}\text { Dorsal } \\
\text { finlets }\end{array}$ & $\begin{array}{l}\text { Anal } \\
\text { fin }\end{array}$ & $\begin{array}{c}\text { Anal } \\
\text { finlets }\end{array}$ & Gill rakers & $\begin{array}{l}\text { Verte- } \\
\text { brae }\end{array}$ & $\begin{array}{l}\text { Branchi- } \\
\text { ostegals }\end{array}$ \\
\hline \multicolumn{9}{|l|}{ Hawaii: } \\
\hline Matsumoto (1960a) & XI & $10-12$ & 8 & 13 & 7 & $(9-10)+1+(28-31)=39-42$ & $20+19$ & - \\
\hline Yoshida and Nakamura & & & & & & & & \\
\hline$(1965)$ & - & - & - & - & - & $(9-10)+1+(29-31)=39-42$ & - & - \\
\hline \multicolumn{9}{|l|}{ Japan: } \\
\hline Kishinouye (1923) & $\mathrm{X}-\mathrm{XI}$ & 12 & 8 & 13 & 7 & $9+30$ & $20+19$ & - \\
\hline \multicolumn{9}{|l|}{ Philippines: } \\
\hline Wade (1949) & X-XII & $10-12$ & 8 & II, 8-11 & 7 & $(9-10)+1+(27-32)=37-43$ & - & 7 \\
\hline \multicolumn{9}{|l|}{ India: } \\
\hline Jones (1958) & $\mathrm{X}$ & 13 & 8 & ii, 11 & 7 & 40 & - & - \\
\hline
\end{tabular}

Table 2.-Meristic characters of the long-corseletted bullet tuna, Auxis rochei, by various investigators.

\begin{tabular}{|c|c|c|c|c|c|c|c|}
\hline & $\begin{array}{c}\text { First } \\
\text { dorsal fin }\end{array}$ & $\begin{array}{c}\text { Second } \\
\text { dorsal fin }\end{array}$ & $\begin{array}{l}\text { Dorsal } \\
\text { finlets }\end{array}$ & $\begin{array}{c}\text { Anal } \\
\text { fin }\end{array}$ & $\begin{array}{l}\text { Anal } \\
\text { finlets }\end{array}$ & Gill rakers & $\begin{array}{l}\text { Verte- } \\
\text { brae }\end{array}$ \\
\hline \multicolumn{8}{|l|}{ Hawaii: } \\
\hline Matsumoto (1960a) & $\mathrm{X}-\mathrm{XI}$ & $10-11$ & 8 & $12-13$ & 7 & $(10-11)+1+(32-36)=43-48$ & $20+19$ \\
\hline $\begin{array}{l}\text { Yoshida and Nakamura } \\
\text { (1965) }\end{array}$ & - & - & - & - & - & $(10-11)+1+(33-37)=44-49$ & - \\
\hline $\begin{array}{l}\text { Japan: } \\
\text { Kishinouye (1923) }\end{array}$ & IX-X & $10-12$ & 8 & 13 & 7 & $10+36$ & $20+19$ \\
\hline $\begin{array}{l}\text { Philippines: } \\
\text { Wade (1949) }\end{array}$ & $\mathrm{X}-\mathrm{XI}$ & $10-12$ & $7-8$ & II, $10-12$ & 7 & $(10-12)+1+(31-35)=44-48$ & - \\
\hline Indonesia: & & & & & & & \\
\hline $\begin{array}{l}\text { De Beaufort and } \\
\text { Chapman (1951) }\end{array}$ & $\mathrm{X}$ & 11 & $6-9$ & 14 & $6-8$ & - & - \\
\hline South Africa: & & & & & & & \\
\hline Talbot (1964) & $\mathrm{X}-\mathrm{XII}$ & 11 & 8 & 14 & $6-7$ & $(9-10)+(32-34)$ & - \\
\hline $\begin{array}{l}\text { India: } \\
\text { Jones (1963) }\end{array}$ & $x-7>-2+2$ & 13 & 8 & 13 & 7 & $(8-12)+(31-36)$ & \\
\hline
\end{tabular}

species stems from an overlap in the width of the corselet. Klawe (1963), lacking evidence to substantiate the presence of two distinct species of Auxis in the eastern Pacific, noted that there were intermediate forms of the short- and long-corseletted forms. Provisionally, he used A. thazard for frigate tuna from this region, but emphasized the possibility that as samples accumulate, there may be sufficient evidence to substantiate the presence of two separate species. From the Indian Ocean, a few large adults of $A$. thazard from the southwest coast of India were recognized as having a corselet that narrowed gradually somewhat as in $A$. rochei instead of one which tapered abruptly (Fig. 2) (Jones 1963).

In an attempt to unravel the confusion involving this genus, Fitch and Roedel (1963) examined numerous adult Auxis, mostly from the Pacific, but failed to find any significant morphometric differences among $A$. thazard from the western, central, and eastern Pacific (Table 3). Based on gill raker counts, they concluded that the eastern Pacific population seems to be separable from those in the central and western Pacific (Table 4 ). For adult $A$. rochei, Fitch and Roedel found apparent differences in body measurements among areas (Table 5) and in the average number of scale rows in the corselet. In an earlier study, Matsumoto (1960a) observed that the number of scale rows in the corselet increased with fish length. But Fitch and Roedel showed that in addition to the positive relationship between these two variables, there was also an increase in the average number of scale
Table 3.-Selected measurements of Auxis thazard from three geographical localities (Fitch and Roedel 1963).

\begin{tabular}{lccc}
\hline & $\begin{array}{c}\text { Western } \\
\text { Pacific }\end{array}$ & $\begin{array}{c}\text { Central } \\
\text { Pacific }\end{array}$ & $\begin{array}{c}\text { Eastern } \\
\text { Pacific }\end{array}$ \\
\hline $\begin{array}{l}\text { Number of specimens } \\
\text { Ranges in standard length } \\
\text { (mm) }\end{array}$ & 10 & 14 & 60 \\
Ranges in percent of & $200-402$ & $248-384$ & $263-392$ \\
$\quad$ standard length: & & & \\
$\quad$ Head & $26.5-28.9$ & $27.5-29.4$ & $27.4-29.5$ \\
$\quad$ Eye & $4.7-5.5$ & $4.8-5.5$ & $4.2-5.1$ \\
$\quad$ Snout & $6.3-7.5$ & $6.4-7.4$ & $5.7-6.8$ \\
$\quad$ Pectoral length & $12.2-14.2$ & $13.1-14.9$ & $12.7-14.6$ \\
$\quad$ Snout to first dorsal & $30.6-33.2$ & $32.3-33.6$ & $31.8-34.5$ \\
$\quad$ Snout to second dorsal & $61.5-66.2$ & $62.6-66.9$ & $64.6-69.0$ \\
$\quad$ Snout to anal & $67.8-72.2$ & $68.3-72.1$ & $68.3-74.2$ \\
$\quad$ Depth & $21.5-25.2$ & $20.6-25.3$ & $22.4-26.4$ \\
$\quad$ Width & $14.6-17.2$ & $15.1-19.5$ & $16.7-20.2$ \\
\hline
\end{tabular}

rows for similar-sized fish from west to east. Auxis rochei in the western Atlantic had the fewest scale rows whereas those in the eastern Pacific had the most. And for $A$. thazard, Tortonese (1965) added that the Mediterranean forms have characters that are not entirely identical to those of the Indo-Pacific forms and suggested that geographical variations may be involved.

As a result of their study, Fitch and Roedel (1963) tentatively recognized two valid species- $A$. thazard and A. rochei. A summary of external and internal characters used by several investigators to differentiate the two species of Auxis is given in Table 6. 

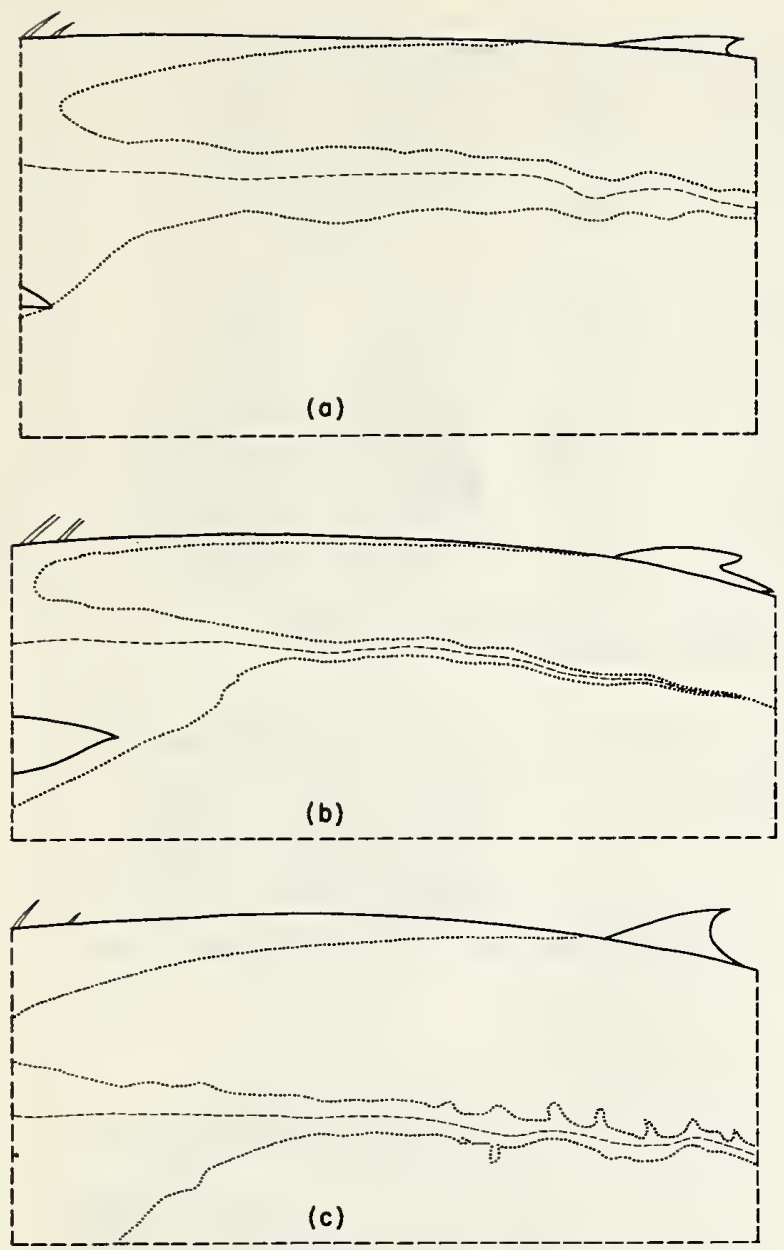

Figure 2.-Outlines of corselets drawn from actual specimens (Jones 1963). (a) Auxis rochei; (b) A. thazard - typical shortcorseletted condition; (c) A. thazard - intermediate condition.

Among internal characters that have been a source of confusion is the gill raker count. Wade (1949) and Herre and Herald (1951) pointed out that $A$. thazard in the western Pacific normally have fewer gill rakers than $A$. rochei. And A. thazard taken in the eastern Pacific and the Indian Ocean also have counts that are definitely lower (Mead 1951; Jones 1963). Godsil (1954), on the other hand, reported that all the $A$. thazard taken off Baja California and the Galapagos Islands have high gill raker counts similar to those reported for $A$. rochei by Wade (1949) and Herre and Herald (1951). Matsumoto (1959), however, believed that the number of gill rakers, by itself, is not a reliable character in identifying the two species of Auxis. But Jones and Silas (1964) suggested that the gill raker counts could be useful; in case of doubtful identification from external characters, a combination of gill raker counts and corselet width should facilitate specific identity.

Jones and Silas (1964) have used body cross section as an aid to identification but Collette and Gibbs (1963a) have warned that this character is difficult to use (Fig. 3 ). Also suggested by Jones and Silas was the position of the visceral organs (Fig. 4). Godsil (1954) and Yoshida and Nakamura (1965) noted that other prominant differences between the two species occur in the skeletal structure. In $A$. thazard, the temporal crests diverge anteriorly so that they are not parallel to one another (Fig. 5 ) and the width of the skull is wider in relation to body length (Fig. 6). Yoshida and Nakamura also noted that the length of the anterior branch of the haemal processes was longer and touching on the preceding arch of the 24 th to the 28th vertebrae in A. thazard (Fig. 7).

\subsection{Protein specificity}

Taniguchi and Nakamura (1970) examined muscle protein of $A$. thazard and $A$. rochei by the cellulose acetate electrophoretic method to determine whether specific divergence occurred between species. They found five components in the electropherograms of both species, but some components were not common to both. The genus Auxis, they concluded, contains two distinct species based on external and internal morphological characters although they are closely related.

To analyze muscle protein polymorphism in Auxis collected from the coastal region of Kochi Prefecture, Japan, Taniguchi and Konishi (1971) used starch-gel electrophoresis and detected differences in protein specificity between $A$. thazard and A. rochei. They concluded that whereas no individual variation could be recognized in electropherograms of 11 specimens of $A$.

Table 4.-Comparison of gill raker counts for 84 Auxis thazard from three geographical localities (Fitch and Roedel 1963).

\begin{tabular}{|c|c|c|c|c|c|c|c|c|c|c|c|c|c|c|c|}
\hline \multirow[b]{3}{*}{ Area } & \multicolumn{15}{|c|}{ Number of rakers on first arch } \\
\hline & \multicolumn{5}{|c|}{ Upper limb } & \multirow{2}{*}{$\frac{\text { Center }^{1}}{1}$} & \multicolumn{9}{|c|}{ Lower limb } \\
\hline & 8 & 9 & 10 & 11 & 12 & & 28 & 29 & 30 & 31 & 32 & 33 & 34 & 35 & 36 \\
\hline Western Pacific & 1 & 7 & 1 & 1 & 一 & 10 & 1 & 1 & 5 & 2 & 1 & - & - & - & - \\
\hline Central Pacific & 一 & 6 & 8 & - & - & 14 & - & 3 & 6 & 5 & - & - & - & - & - \\
\hline \multirow[t]{2}{*}{ Eastern Pacific } & - & 4 & 31 & 24 & 1 & 60 & - & - & 1 & 5 & 11 & 14 & 19 & 9 & 1 \\
\hline & & & & & \multicolumn{11}{|c|}{ Total number of rakers } \\
\hline Area & & & & & 38 & 39 & 40 & 41 & 42 & 43 & 44 & 45 & 15 & 46 & 47 \\
\hline Western Pacific & & & & & 2 & - & 4 & 2 & 1 & 1 & - & - & - & - & - \\
\hline Central Pacific & & & & & - & 3 & 2 & 5 & 4 & 一 & - & - & - & - & - \\
\hline Eastern Pacific & & & & & - & - & - & 1 & 5 & 8 & 13 & 15 & 15 & 11 & 7 \\
\hline
\end{tabular}

${ }^{1}$ On all specimens the center raker has roots extending into both limbs. 
Table 5.-Selected measurements of Auxis rochei from five geographic localities (Fitch and Roedel 1963).

\begin{tabular}{|c|c|c|c|c|c|}
\hline & $\begin{array}{l}\text { Western } \\
\text { Atlantic }\end{array}$ & $\begin{array}{l}\text { Eastern } \\
\text { Atlantic }\end{array}$ & $\begin{array}{l}\text { Western } \\
\text { Pacific }\end{array}$ & $\begin{array}{l}\text { Central } \\
\text { Pacific }\end{array}$ & $\begin{array}{l}\text { Eastern } \\
\text { Pacific }\end{array}$ \\
\hline Number of specimens & 24 & 3 & 6 & 2 & 28 \\
\hline Ranges in standard length ( $\mathrm{mm}$ ) & $277-347$ & $368-398$ & $206-250$ & $272-277$ & $253-352$ \\
\hline \multicolumn{6}{|l|}{$\begin{array}{l}\text { Ranges in percent of standard } \\
\text { length: }\end{array}$} \\
\hline Head & $26.3-28.0$ & $26.1-26.9$ & $26.0-27.8$ & $27.4-27.8$ & $26.4-28.1$ \\
\hline Eye & $4.5-5.1$ & 4.6 & $4.8-5.4$ & 5.1 & 4.5-5.3 \\
\hline Snout & $6.0-7.3$ & $6.3-6.6$ & $5.8-6.8$ & $6.6-7.2$ & b.0-6.6 \\
\hline Pectoral length & $12.0-14.0$ & $12.2-12.7$ & $11.7-13.2$ & $13.1-13.7$ & $12.2-13.9$ \\
\hline Snout to first dorsal & $30.7-33.3$ & $30.7-31.9$ & $30.4-32.5$ & $31.3-32.5$ & $30.7-33.0$ \\
\hline Snout to second dorsal & $63.3-67.8$ & $66.4-68.6$ & $64.0-65.8$ & $65.1-66.8$ & $65.4-68.3$ \\
\hline Snout to anal & $68.2-73.9$ & $71.1-72.4$ & $68.8-72.8$ & $71.3-71.5$ & $68.0-74.0$ \\
\hline Depth & $20.5-24.2$ & $23.2-23.6$ & $19.8-21.4$ & $20.6-21.0$ & $22.1-24.3$ \\
\hline Width & $14.7-18.1$ & $17.9-20.6$ & $13.3-16.1$ & $14.7-15.2$ & $16.4-18.9$ \\
\hline Ranges in scale rows & $6-9$ & $7-10$ & '9-13 & ${ }^{1} 11-15$ & $13-28$ \\
\hline
\end{tabular}

'Matsumoto (1960a) gives 9-15 for 9 western Pacific specimens and 16-18 for 20 from the central Pacific. Fitch and Roedel's (1963) two central Pacific specimens were from Matsumoto's lot of 20.

Table 6.-Characters used by several investıgators to differentiate Auxis thazard from A. rochei (Godsil 1954; Fitch and Roedel 1963; Jones and Silas 1964; Yoshida and Nakamura 1965).

Auxis thazard

1. Fifteen or more oblique to nearly horizontal dark wavy lines in bare area on each side of back.

2. Corselet of scales running along lateral line is, at most, three rows wide where it passes beneath second dorsal.

3. Pectoral fins extend beyond a vertical from anterior margin of patterned bare area on back.

4. Body compressed from side to side (Fig. 3).

5. Shape of abdominal cavity more oval.

6. Right lobe of liver makes a complete loop crossing over midventral longitudinal axis (Fig. 4).

7. Stomach extends to slightly behind anal opening as does right lobe of liver.

8. Caecal mass occupies less space, spleen is smaller, and left lobe of liver relatively long.

9. Temporal crests diverge anteriorly and not parallel with each other (Fig. 5).

10. Skull wide relative to its length (Fig. 6).

11. Anterior branch of haemal processes long and touching preceding haemal arches on 24 th to 28 th vertebrae (Fig. 7 ).
Auxis rochei

Fifteen or more broad, nearly vertical dark bars on bare area on each side of back.

Corselet with more than six rows of scales where it passes beneath second dorsal.

Pectoral fins fail to reach vertical beneath the anterior end of the dorsal bare area.

Body more rounded and robust.

Shape of abdominal cavity dorsally compressed.

Right lobe of liver shows no looping and hepatic vein not in line with midventral longitudinal axis.

Stomach is short with distal end not reaching anal opening and right lobe of liver extends backward but does not surpass a line drawn from origin of anal fin.

Caecal mass occupies more space, spleen is larger, and left lobe of liver relatively short.

Temporal crests of skull parallel with each other and supraoccipital crest.

Skull narrow relative to its length.

Anterior branch of haemal processes short, fragile, and separated from preceding haemal arches. thazard, all 170 specimens of $A$. rochei fitted into one of three phenotypic protein patterns. They hypothesized that these three phenotypes are controlled by two codominant alleles. Furthermore, the distribution of the three phenotypes was independent of age and sex.

Almost all proteinases found in animal meat exhibit $\mathrm{pH}$ optima in the acid range; however, Makinodan and Ikeda (1969), studying fish muscle protease, concluded that there are actually two types of proteinases in fish muscle-one acting in the acid $\mathrm{pH}$ range and the other in the slightly alkaline range. They found that the former occurred in all fish tested whereas the latter was only in fishes with white flesh except the cod, Gadus macrocephalus. For red or slightly red-flesh fish such as albacore, Thunnus alalunga; bullet tuna, $A$. rochei; common mackerel, Scomber japonicus; sardine, Sardinops melanosticta; yellowtail, Seriola quinqueradiata; and horse mackerel, Trachurus japonicus, proteinase activity was either low or not present.

In attempts to find an easier and faster method of identifying larval and postlarval tunas, Matsumoto (1960b) experimented with paper chromatography, an important technique used to identify chemical compounds. On the assumption that the free amino acids in the muscle tissues of fishes are hereditary, Matsumoto attempted to separate adult $A$. thazard from $A$. rochei but encountered difficulty in distinguishing them; however, he was able to separate the two species from other tunas.

Sharp and Pirages (1978) inferred the phylogeny of several species in the four tribes of the subfamily Scombrinae, based on comparison of electrophoretic mobilities of several proteins. Calculating the percentage of protein bands that are shared and that show similarity between species pairs, they concluded that Euthynnus lineatus is more primitive than $A$. thazard. Placement of $A$. thazard above $E$. lineatus in the phylogeny is supported by the higher affinity of Auxis to both Thunnus albacares and $E$. lineatus than $E$. lineatus exhibits to any of the other Thunnini. 






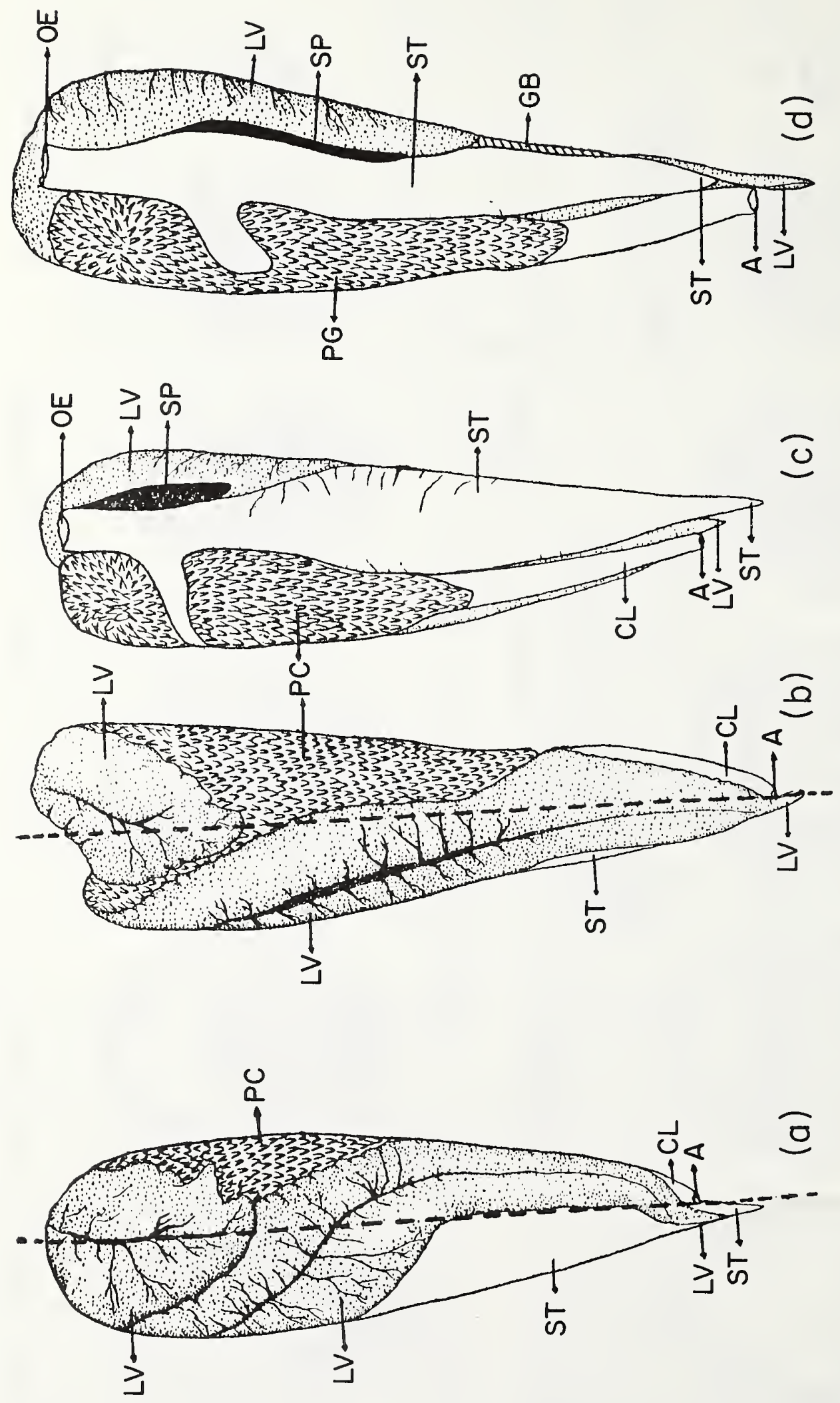

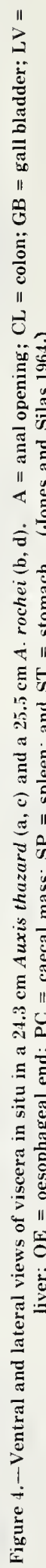




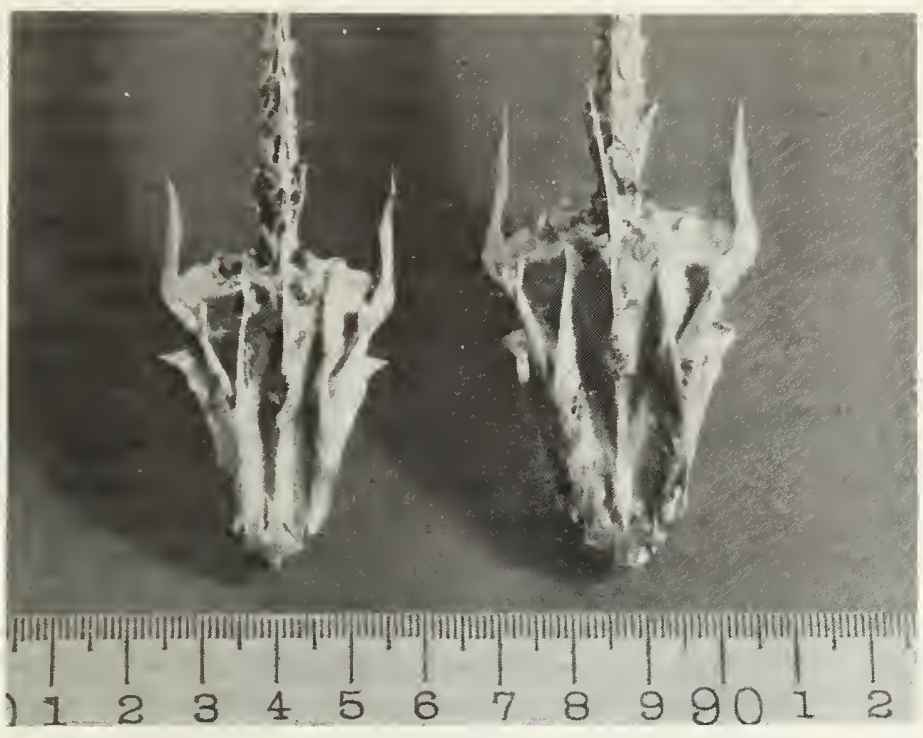

Figure 5.-Dorsal view of skull of $A$ uxis rochei (ca. $27 \mathrm{~cm} \mathrm{SL}$ ) on the left and $A$. thazard (ca. $30 \mathrm{~cm} \mathrm{SL}$ ) on the right. Note that the temporal crests of the $A$. rochei skull are parallel with each other and with the supraoccipital crest, whereas in A. thazard the temporal crests diverge anteriorly so that the three crests are not distinctly parallel (Yoshida and Nakamura 1965).

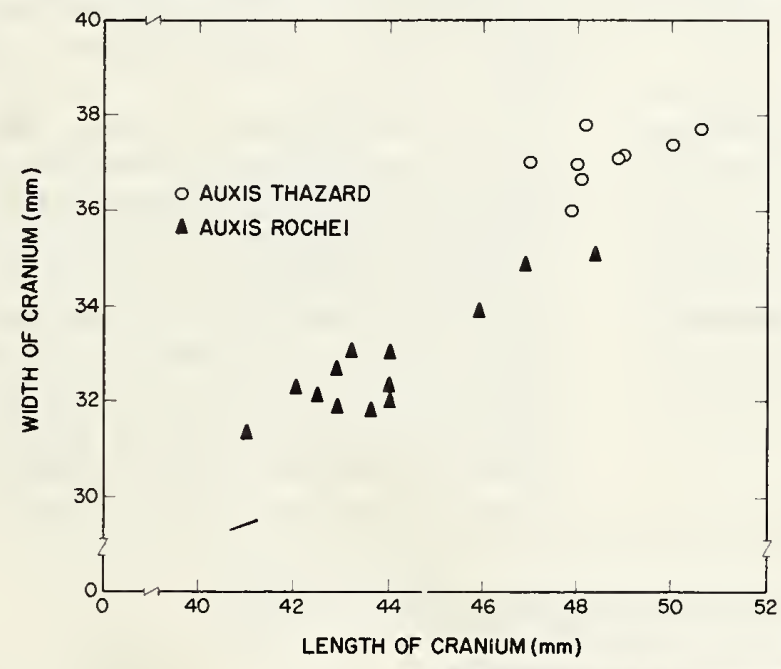

Figure 6.-Relation between the width and length of the cranium of $A$ uxis thazard and $A$. rochei. Width: distance between widest points of pterotic processes; length: distance from anterior margin of vomer to concave ventral tip of aperature of myodome. (Yoshida and Nakamura 1965.)

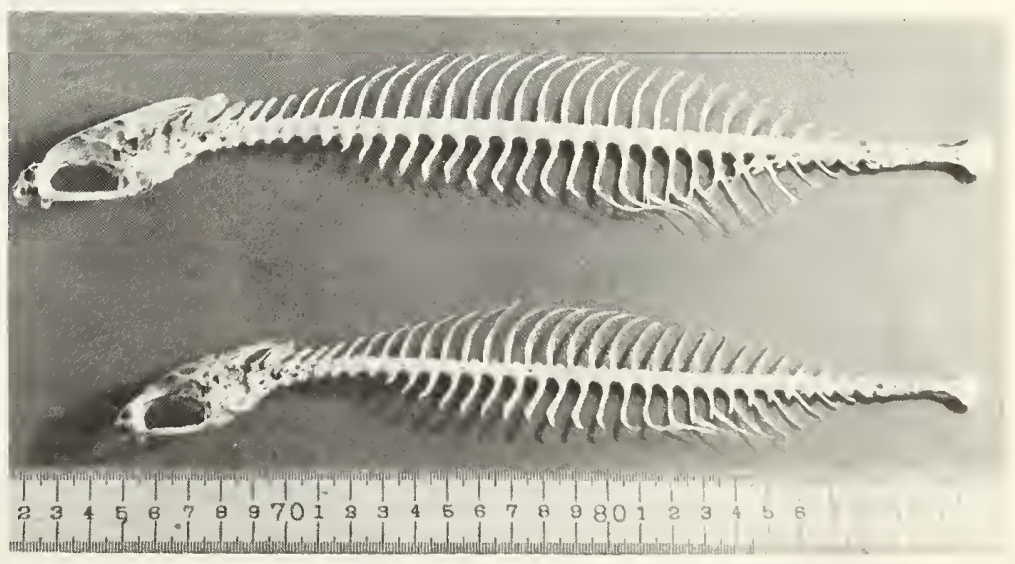

Figure 7.-Lateral view of skleton of Auxis thazard (top) and A. rochei (bottom). Note that in $A$. thazard, the anterior branch of the haemal processes are much longer than in $A$. rochei and that they are in contact with the preceding haemal arches on the 24 th to the 28th vertebrae (Yoshida and Nakamura 1965). 


\section{DISTRIBUTION}

\subsection{Total area}

The genus Auxis is distributed worldwide in tropical and subtropical waters.. The confusion surrounding the identification of the two species of Auxis is reflected in their reported distribution in the world's oceans. Fitch and Roedel (1963) concluded from their study that $A$. rochei was cosmopolitan in distribution whereas $A$. thazard was restricted to the Pacific. Collette and Gibbs (1963a) expressed uncertainty about the presence of both species of Auxis in the Atlantic but stated that both probably do occur there. Richards and Randall (1967) independently confirmed that adult $A$. thazard do occur in the Atlantic.

The distribution of $A$. thazard cannot be separated from that of $A$. rochei at the present time because of difficulties in the past in distinguishing one species from the other (Yabe et al. 1963). Therefore, the reported distribution in the literature for either $A$. thazard or $A$. rochei is questionable and needs to be critically reexamined. The following discussion takes into account the distribution of both species. Figure 8 shows the distribution of Auxis adults in relation to water and land areas.

In the Pacific Ocean, Auxis occur off the coast of the United States between Santa Catalina Island and San Clemente Island off California southward into the eastern tropical Pacific extending as far south as lat. $18^{\circ} \mathrm{S}$ (Radovich 1961; A. Ch. de Vildoso ${ }^{5}$ ). They have also been reported from the Hawaiian (Matsumoto 1960a) and Marquesas Islands (Nakamura and Matsumoto 1967). In the western Pacific, they occur off the coast of Japan as far north as Hokkaido, off Korea, off the coast

A. Ch. de Vildoso, Instituto del Mar. Callao, Peru, pers. commun. December 1975 . of China mainland near southern Manchuria and Ningpo, around Formosa, and in waters surrounding the Ryukyu and Bonin Islands (Rosa 1950). Southward, Auxis have been reported from Samoa Islands and Papua New Guinea (Jordan and Seale 1906), the Philippine Islands (Herre 1953), along the eastern and southern coasts of Australia (Scott 1962; Laevastu and Rosa 1963; Whitley 1964), Tasmania (Lord 1927), and New Zealand (Roberts et al. 1977).

The usual latitudinal range reported for Auxis in the tropical and subtropical waters of the Atlantic Ocean is from lat. $45^{\circ} \mathrm{N}$ to $35^{\circ} \mathrm{S}$ (Collignon see footnote 2; Miyake and Hayasi 1972). In the eastern Atlantic, they occur infrequently as far north as Bergen, Norway, and the canal of Oslo Harbor (Rosa 1950) and in waters around the British Isles (Went 1955, 1956, 1958, 1967; Rae 1963; Went and Kennedy 1969; Wheeler and Blacker 1969). Auxis also occur in the Mediterranean and Black Seas. Southward, they are found in waters off the Republic of South Africa and offshore around Ascension and St. Helena Islands. In the western Atlantic, the northernmost occurrence of Auxis is off Barnstable, Mass., in the Gulf of Maine (Mather and Gibbs 1957). Southward in the western Atlantic, Auxis have been reported from the Gulf of Mexico, the Caribbean Sea, and the Atlan tic as far south as Mar del Plata, Argentina (López 1961).

In the eastern Indian Ocean, Auxis have been reported from the east coast of India and southward along the Indonesian Archipelago to Cape Leeuwin near the southern tip of Western Australia (Rosa 1950; Jones and Silas 1964; Nair et al. 1970). The western Indian Ocean distribution of Auxis extends from the west coast of India offshore to the Maldive and Laccadive Islands, the coast of Iraq in the Persian Gulf (Mahdi 1971), the Red Sea (Ben-Tuvia 1968), and from the Gulf of Aden southward to the coast of Natal in the Republic of South Africa (Williams 1963; Nair et al. 1970).

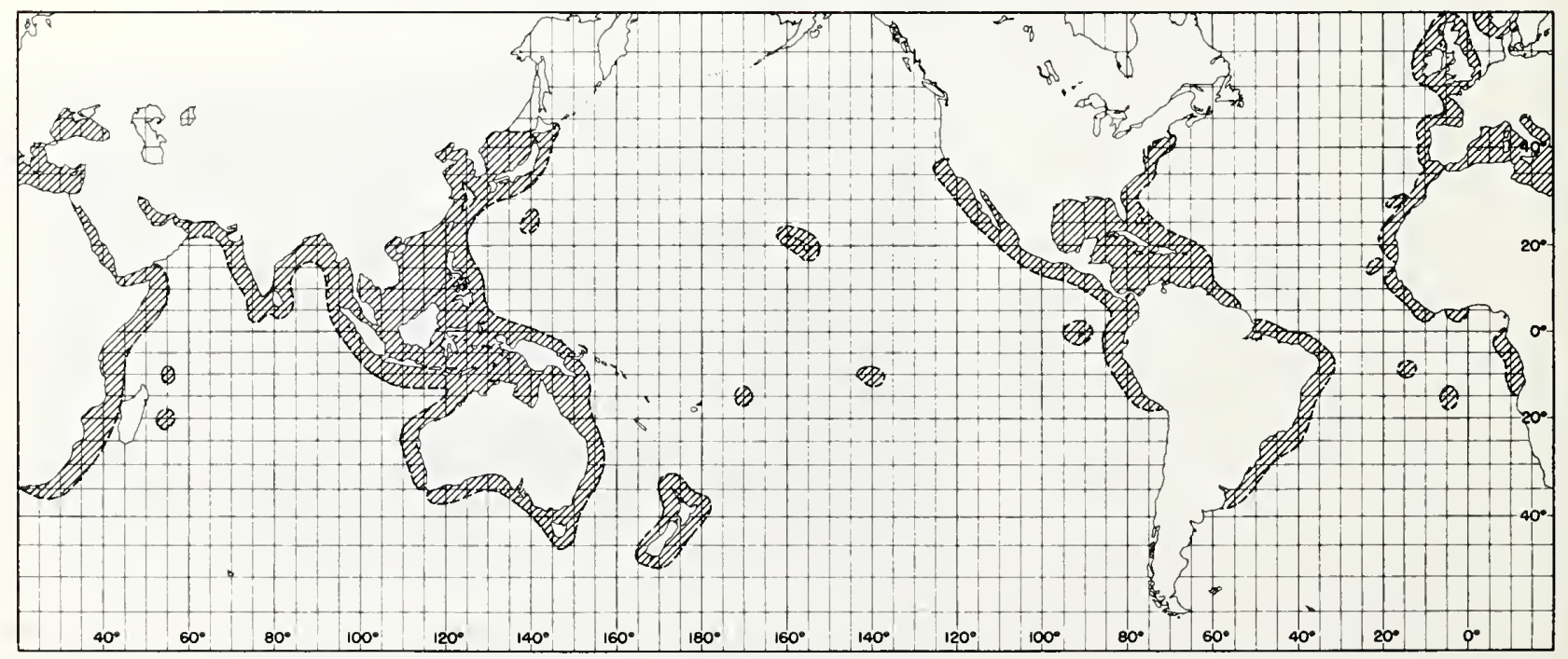

Figure 8.-The distribution of Auxis spp. adults in relation to water and land areas in the world's ocean. 


\subsection{Differential distribution}

\subsection{Spawn, larvae, and juveniles}

The larvae of Auxis, like the eggs which precede them, are displaced from the area of spawning due to drift of the ocean currents (Matsumoto 1958, 1959). Except in a few areas where currents are swift, the actual displacement of eggs and larvae appears to be relatively insignificant.

Whereas the distribution of adult Auxis is usually associated with land masses, that of the larvae has been described as not only coastal but also oceanic. Figure 9 shows the localities of capture of Auxis larvae in the world's oceans. The actual differences in larval and adult distributions, however, may not be real. The adults are usually reported to occur in coastal waters because most of the fishing is done there. But plankton hauls conducted in waters far from land masses have shown that larval Auxis occur in oceanic as well as coastal waters. Matsumoto $(1958,1959)$ suggested that the localities where larvae of about $3 \mathrm{~mm}$ occur probably represent actual spawning sites; therefore, it can be expected that adult Auxis also occur in the oceanic regions of the world's oceans. Watanabe (1964), on the other hand, studying tuna and billfish stomach contents, concluded that Auxis are coastal dwellers.

The distribution of juvenile Auxis, $10-20 \mathrm{~cm}$ SL (standard length), agrees well with that of the larvae, especially near land masses, but in the oceanic regions the presence of juveniles have not been well documented (Fig. 10). Yabe et al. (1963) pointed out that the usual method of using a midwater trawl to collect juveniles has not been successful quantitatively; rather, more information can be obtained through examination of stomach contents of large tunas and billfishes.

That juvenile Auxis occur mostly in waters close to land masses is brought out in Table 7 which shows the number of juvenile Auxis taken by midwater trawl in Hawaiian waters. Higgins (1970) observed that in JulySeptember 1967, the catch rate of juvenile Auxis reached 3.5 individuals/tow, the highest among all the

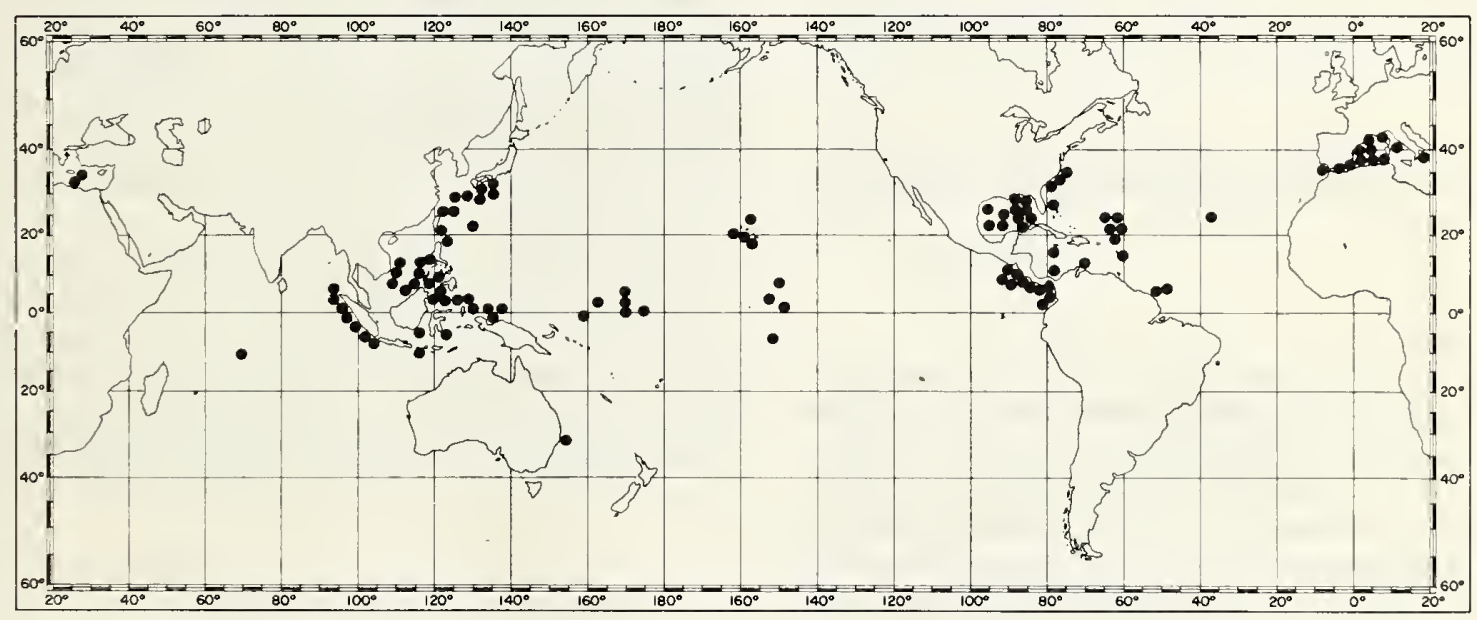

Figure 9.-Localities of capture of larval Auxis (Yabe et al. 1963).

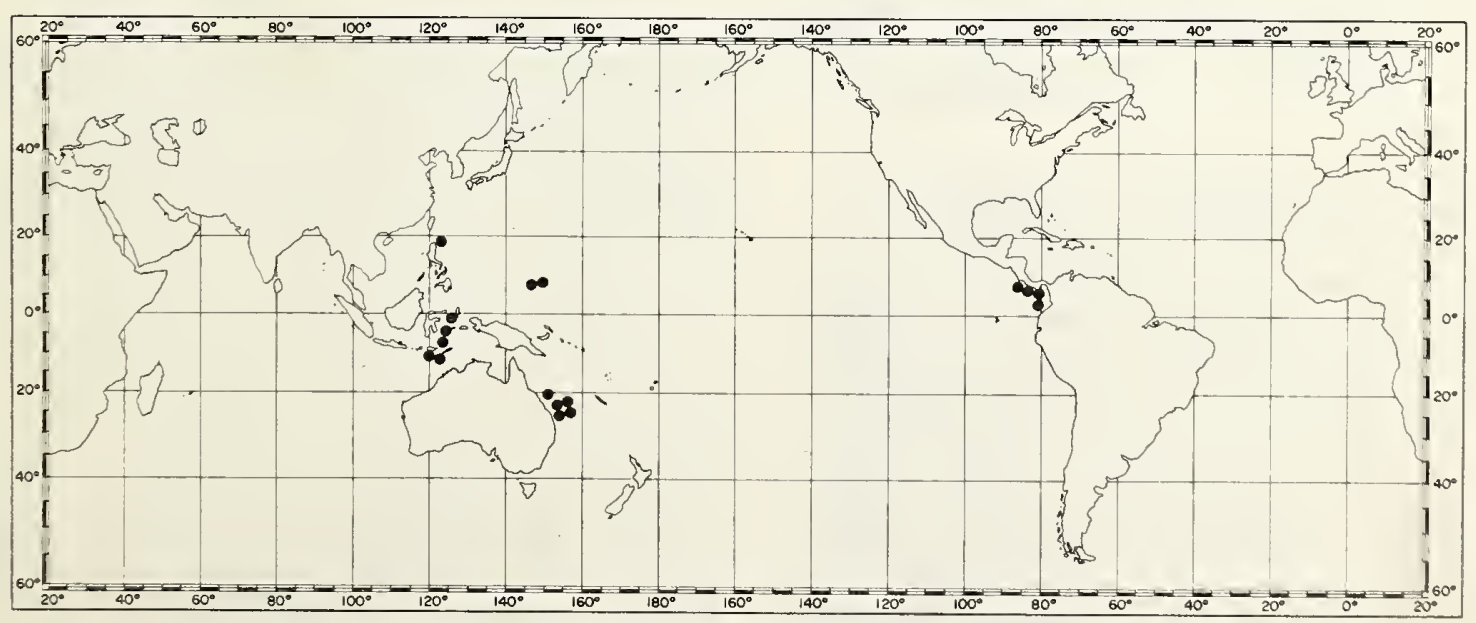

Figure 10.-Localities of capture of juvenile (10-20 cm SL) Auxis (Yabe et al. 1963). 
Table 7.-Total number of juvenile Auxis and (in parentheses) the average number per tow collected by a $12 \mathrm{~m}$ wide by $8 \mathrm{~m}$ high midwater trawl during the day (1200-1800), night (2000-0200), and morning (0400-1000), RV Townsend Cromwell cruise 32, 12 July-25 September 1967. The trawl, fished at a depth of $100 \mathrm{~m}$ during deep hauls and $20 \mathrm{~m}$ during shallow hauls, was towed at a speed of 1.5 $\mathrm{m} / \mathrm{s}$ (Higgins 1970).

\begin{tabular}{|c|c|c|c|c|c|}
\hline \multirow{2}{*}{$\begin{array}{c}\begin{array}{c}\text { Area and } \\
\text { month }\end{array} \\
\text { Inshore Oahu: }\end{array}$} & \multirow[t]{2}{*}{$\begin{array}{c}\text { Number } \\
\text { of tows }\end{array}$} & \multicolumn{2}{|c|}{ Frigate tuna } & \multicolumn{2}{|c|}{ Total tunas } \\
\hline & & & & & \\
\hline July & 18 & 7 & $(0.4)$ & 55 & $(3.0)$ \\
\hline August & 10 & 9 & $(0.9)$ & 28 & $(2.8)$ \\
\hline September & 8 & 111 & $(13.9)$ & 174 & $(21.8)$ \\
\hline Total & 36 & 127 & $(3.5)$ & 257 & $(7.1)$ \\
\hline \multicolumn{6}{|l|}{ Offshore Oahu: } \\
\hline July & 11 & 6 & $(0.5)$ & 155 & $(14.1)$ \\
\hline August & 18 & $\underline{0}$ & & 380 & $(21.2)$ \\
\hline Total & 29 & 6 & $(0.2)$ & 535 & (18.4) \\
\hline \multicolumn{6}{|l|}{ Molokai': } \\
\hline August & 2 & 0 & & 1 & $(0.5)$ \\
\hline \multicolumn{6}{|l|}{ Lanai ${ }^{1}:$} \\
\hline September & 4 & 0 & & 0 & \\
\hline \multicolumn{6}{|l|}{ Hawaii: } \\
\hline September & 12 & 0 & & 202 & $(16.8)$ \\
\hline Grand total & 83 & 133 & (1.6) & 995 & $(12.0)$ \\
\hline
\end{tabular}

'The duration of these tows was $<6 \mathrm{~h}$.

young tunas collected in inshore waters off the island of Oahu. Offshore, the catch rate dropped to 0.2 juvenile/ tow.

\subsection{Adults}

Despite the argument that the distribution of $A$. thazard cannot be separated from that of $A$. rochei because of difficulties in distinguishing the two species, a study of stomach contents of tunas and billfishes indicated that there are conspicuous differences between the pattern of occurrence of these two species. Watanabe (1964) found that in the Banda Sea, specimens of $A$. rochei were found in the stomach contents more frequently than those of $A$. thazard, although both species occurred there. This pattern of occurrence reflected the difference in abundance of the two species in the Banda Sea. Off the Queensland coast in Australia, all the specimens collected from tuna and billfish stomachs were $A$. rochei.

\subsection{Determinants of distribution changes}

The extreme southern boundary of the distribution of Auxis in the Indian Ocean lies at about lat. $36^{\circ} \mathrm{S}$ which is extremely close to the position of the $20^{\circ} \mathrm{C}$ isotherm for the greater part of the year, including the southern summer (Williams 1963). Off South Africa and Australia, the occurrence of Auxis coincides with the time of maximum water temperature. Likewise, off East Africa and the Seychelles, Auxis occur in the months of the northwest monsoon when the temperature is maximal at about $29^{\circ}-30^{\circ} \mathrm{C}$. The appearance of Auxis in East African inshore waters also coincides with the time of greatest fertility of the surface waters.
Temperature, it has been shown, is clearly a highly important variable in explaining the distribution of Auxis larvae. Klawe et al. (1970) observed that the optimum temperature of surface waters under which larval Auxis are found is between $27.0^{\circ}$ and $27.9^{\circ} \mathrm{C}$ (Fig. 11). Their tolerance for temperature, however, is very wide. Richards and Simmons (1971) determined that Auxis larvae occur in waters with surface temperatures as low as $21.6^{\circ} \mathrm{C}$ and as high as $30.5^{\circ} \mathrm{C}$, the widest range among any of the tuna larvae they studied.

The vertical distribution of larval Auxis has been reported to be limited to the layer above the thermocline. Comparing average catches of tuna (including Auxis) larvae for two types of plankton tows made in the eastern Pacific, Klawe (1963) found that the surface tows usually caught 9.2 times as many larvae as the deep tows. But comparison of catches made by surface and by $140 \mathrm{~m}$ oblique tows showed that the former caught an average of only 3.2 times as many larvae as the latter. In fact, the numbers of larvae caught in the simultaneous surface and oblique tows were significantly correlated. Klawe found that the relative number of tuna larvae taken in surface and oblique hauls approximates the ratio obtained from the depth of the oblique tow to the depth of the layer above the thermocline thus substantiating the conclusion earlier reached by others that larvae are limited to the layer above the thermocline.

Among other determinants of larval distribution that have been examined are salinity, plankton, and light conditions. Klawe et al. (1970) found no relationship between zooplankton volumes and larval catches; therefore, their findings are in agreement with those of Strasburg (1960) and Nakamura and Matsumoto (1967) who observed this phenomenon for tuna larvae in

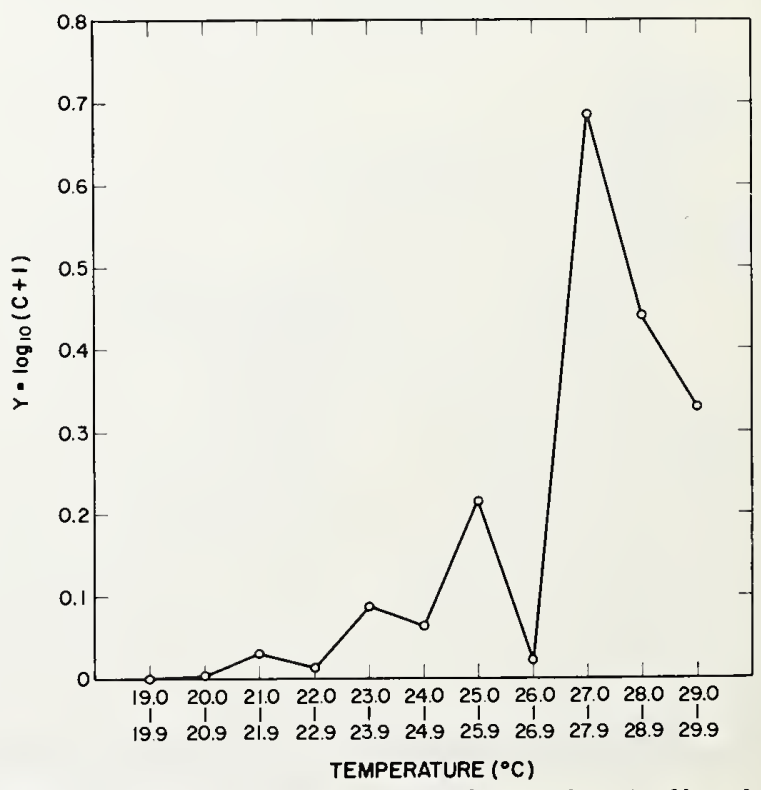

Figure 11.-Average catches, $\log ^{10}$ (number caught +1 ), of larval A uxis grouped according to surface temperatures at the time of capture (Klawe et al. 1970). 
general. Salinity, likewise, showed no relationship with catches of larval Auxis, but Klawe et al. (1970) reasoned that this lack of relationship may be due to the narrow range of salinity encountered during the period that the study was made. Salinity, therefore, cannot be discounted as a factor affecting distribution. In fact, Richards and Simmons (1971) determined that larval Auxis were found in a relatively narrow salinity range from $33.2 \%$ to $35.4 \%$ compared to that of other tunas, with the exception of little tunny, Euthynnus alletteratus.

Concerning the effects of light intensity, Higgins (1970) observed that juvenile Auxis were more vulnerable to the midwater trawl at night than during daylight hours. Furthermore, they were more readily caught in shallower than in deeper tows, although the data suggested that they may occur as deep as $100 \mathrm{~m}$. Strasburg (1960) reported that larval Auxis occur at the surface very infrequently during daylight hours but are often found there in large numbers at night. Noting that this pattern of an increase in catch at night could result from either net avoidance or vertical migration, Strasburg reasoned that if net avoidance only were involved, one would expect the catch to be essentially constant at night. The results of his study proved otherwise; therefore, he concluded that vertical migration appears to be the major factor causing the increase in surface catch at night. Contrarily, in a later study by Klawe et al. (1970), it was observed that larval Auxis show no significant diel movement in the water column. From a statistical test they conducted for time of day as well as for interaction between time of day and type of tow, Klawe et al. (1970) found no interaction between type of tow and time of day; therefore, they concluded that no vertical movement had occurred. They reasoned that any ability larval Auxis may have had to avoid the sampling gear was independent of time of day.

\subsection{Hybridization}

2.41 Hybrids; frequency of hybridication; species with which hybridization occurs; methods of hybridization

There has been considerable progress in studies on egg and larval development of tuna and tunalike fishes in recent years. Most impressive are the experiments by Japanese scientists on artificial fertilization of eggs and the subsequent rearing of the larvae. Among the tuna species that have been used in these experiments were yellowfin, skipjack, frigate, and bullet. In 1970, the Japan Fisheries Agency coordinated a 3-yr cooperative program to artificially fertilize and rear tunas (Ueyanagi et al. 1973). The experiments were conducted through the cooperative efforts of Tokai University, Kinki University, Shizuoka Prefectural Fisheries Experimental Station, Mie Prefectural Owase Fisheries Experimental Station, Nagasaki Prefectural Fisheries Experimental Station, and the Far Seas Fisheries Research Laboratory of the Japan Fisheries Agency.

Experiments conducted at Kinki University Fish- eries Experimental Station (1974) involved crossfertilization of $A$. thazard and $A$. rochei. The ripe eggs taken from $A$. thazard caught by set net at Kashino, Oshima, on 17 July 1973 at 0530 were fertilized and transported to the experimental station at Shirahama. At 1350 on the same day, there were about 35,120 viable eggs which averaged $0.86 \mathrm{~mm}$ in diameter and about 7,000 dead eggs. Twenty-five thousand viable eggs were placed in a 3 -ton (3,000 liter) tank and 10,000 in a 1 -ton (1,000 liter) tank. Water temperature in the tanks was about $26^{\circ} \mathrm{C}$. Larvae started to emerge the next day, approximately $30 \mathrm{~h}$ after fertilization and all hatching was completed during the day. The larvae were kept in seawater with Chlorella which had a density of $400,000 /$ cc. Aeration was also provided. Rotifers were added to the tank 2 days after hatching and marine plankton was added the next day. All the larvae in the 3 ton tank died after 6 days. In the 1-ton tank, although mortality was heavy, there were some survivors. At 14 days, the water was circulated, and at 18 days after hatching, artemia and eggs of frozen yellowtail, Seriola quinqueradiata, were used to supplement the marine plankton. Mortality continued and the last survivor, which attained a length of $4.8 \mathrm{~cm}$ and a weight of $0.907 \mathrm{~g}$ died after 31 days.

\section{BIONOMICS AND LIFE HISTORY}

\subsection{Reproduction}

\subsection{Sexuality}

Like all other scombrids, Auxis are heterosexual. There are no externally visible characters that aid in distinguishing males from females. Internally, the paired and elongated gonads are nearly symmetrical and are suspended by mesenteries extending almost the entire length along the roof of the abdominal cavity. At the posterior end of the abdominal cavity, the gonads extend along both sides of the anal fin. This posterior extension, according to Kishinouye (1923), is due to the narrowness of the abdominal cavity.

\subsection{Maturity}

Studies of gonads of troll-caught fish from waters of Kaneohe Bay, Oahu, in the Hawaiian Islands indicate that frigate tuna are nearly mature at a size of about 35 cm (Tester and Nakamura 1957), but in Japanese waters, they have been reported to reach maturity at about $29 \mathrm{~cm}$. Yasui (1975) investigated the use of liver weight as a possible index of sexual maturity. He plotted liver weight against body length of frigate tuna caught off the Izu Islands and off Mera, Shizuoka Prefecture, and observed a point of discontinuity at a body length of $29 \mathrm{~cm}$. His data also showed that $97 \%$ of the fish $<29 \mathrm{~cm}$ were caught after September whereas $95 \%$ of those larger than that were caught before August. The reproductive index, according to Yasui, was highest in July. 
Observing that almost all fish $>29 \mathrm{~cm}$ had high reproductive indices, Yasui hypothesized that liver weight is related to oogenesis and that it can be used as an indicator of sexual maturity.

In the Spanish trap net fishery located in and around the Strait of Gibraltar, the size of $A$. rochei at first spawning is $35 \mathrm{~cm}$ for the females and $36.5 \mathrm{~cm}$ for the males (Rodríguez-Roda 1966). Rodríguez-Roda classified the testes and ovaries according to the developmental stages as follows:

$\begin{aligned} \text { I } & \text { Immature } & \text { IV } & \text { Prespawning } \\ \text { II } & \text { Maturing } & \text { V } & \text { Spawning } \\ \text { III } & \text { Ripening } & \text { VI } & \text { Spent }\end{aligned}$

Rodríguez-Roda noted that in May, a large proportion of the males and females were in stage III. In JuneAugust some showed development in stage IV, but by September about one-third of the males and one-fourth of the females sampled had gonads that appeared to be spent (Table 8). Rodríguez-Roda noted that gonad classification based on gross characteristics such as he used could lead to misleading conclusions; however, he indicated that the relative gonad weight (gonad weight in relation to body weight) tended to confirm his conclusions.
$125 \mathrm{~g}$, respectively. According to Rao, the smaller of the two fish may "have been captured while in the act of spawning since most of the ripe ova were already lost by the time it was examined."

\subsection{Spawning}

Earlier, it was pointed out that although the planktonic eggs and larvae of Auxis become displaced from the area of spawning due to ocean currents, the displacement is insignificant. Therefore, localities where larvae of $3 \mathrm{~mm}$ or less occur probably represent actual spawning sites.

In the eastern tropical Pacific, Auxis larvae are the most abundant among all the scombrid larvae collected. Ahlstrom (1971) identified 1,563 out of 1,919 scombrid larvae in the EASTROPAC collection as Auxis spp. Based on this information and the distribution of the catches of larval Auxis, Klawe (1963) observed that off Baja California, spawning occurred in coastal waters whereas to the south it appeared to be in more oceanic waters away from continents or islands. The most northerly area of spawning appeared to be near Cedros Island and at the head of the Gulf of California. To the south, Klawe found the limit of spawning to be off Point Santa Elena in Ecuador. He delimited the general area of

Table 8.-Percentages of male and female Auxis rochei from the Spanish trap net fishery classified as I immature, II - maturing, III - ripening, IV - prespawning, V - spawning, and VI - spent in May-September in 1958, 1961, 1963, and 1964 combined (Rodriguez-Roda 1966).

\begin{tabular}{|c|c|c|c|c|c|c|c|c|c|c|c|c|c|c|}
\hline \multirow[b]{2}{*}{ Month } & \multicolumn{7}{|c|}{ Males } & \multicolumn{7}{|c|}{ Females } \\
\hline & $\mathrm{I}$ & II & III & IV & $\mathrm{V}$ & VI & $N$ & $\mathrm{I}$ & II & III & IV & $\mathrm{V}$ & VI & $N$ \\
\hline May & - & 8.57 & 88.57 & 1.43 & - & 1.43 & 70 & - & 12.86 & 75.71 & - & - & 11.43 & 62 \\
\hline June & - & 2.94 & 79.41 & 17.65 & - & - & 34 & - & 6.06 & 69.70 & 24.24 & - & - & 33 \\
\hline July & - & - & 90.00 & 10.00 & - & - & 30 & - & 20.00 & 80.00 & - & - & - & 20 \\
\hline August & - & 2.74 & 97.26 & - & - & - & 73 & - & 1.35 & 94.59 & 2.70 & - & 1.35 & 74 \\
\hline \multirow[t]{2}{*}{ September } & 20.00 & 14.29 & 25.71 & 5.71 & 1.48 & 32.86 & 70 & 32.61 & 17.89 & 15.22 & 8.70 & - & 26.09 & 46 \\
\hline & & & & & & & 277 & & & & & & & 235 \\
\hline
\end{tabular}

\subsection{Mating}

No information is available on the mating habits of Auxis but, in general, it is believed that scombrids release their sexual products directly into the water without pairing of the male and female. The mechanism which triggers the reproductive activity, i.e., spawning and fertilization, is still unknown.

\subsection{Fertilization}

Fertilization is external.

\subsection{Gonads}

The gonads of Auxis are paired, elongate organs suspended from the dorsal wall of the body cavity by lengthwise mesenteries. Rao (1964) described the ovaries of $A$. thazard in "spawn-ripe" condition as pinkish-pale yellow organs. Two samples of ovaries coming from fish measuring 41.6 and $44.2 \mathrm{~cm}$ weighed 52 and occurrence by drawing a straight line from Point Santa Elena to the intersection of lat. $10^{\circ} \mathrm{N}$ and long. $116^{\circ} \mathrm{W}$ and from there to Cedros Island off Baja California.

In the extreme eastern Pacific, $A$. thazard spawn throughout the year, although in the northern region, it may be restricted (Figs. 12, 13). This phenomenon of seasonal spawning in the northern region of the eastern Pacific may be similarly reflected in the most southern region, but data are inadequate to confirm this. Data from collections made off Cape Blanco indicated that Auxis spawn off Costa Rica throughout the year but peak spawning occurs in December-April (Table 9). Klawe et al. (1970), however, observed that the period of peak spawning of $A$. thazard may vary, because their data suggested that larvae were more abundant in August-November with a peak in October (Fig. 14). They suggested that differences in spawning peak between their samples and those examined earlier by Klawe (1963) may be due to differences in sampling locations within the general area, to environmental changes, or other unknown causes. 


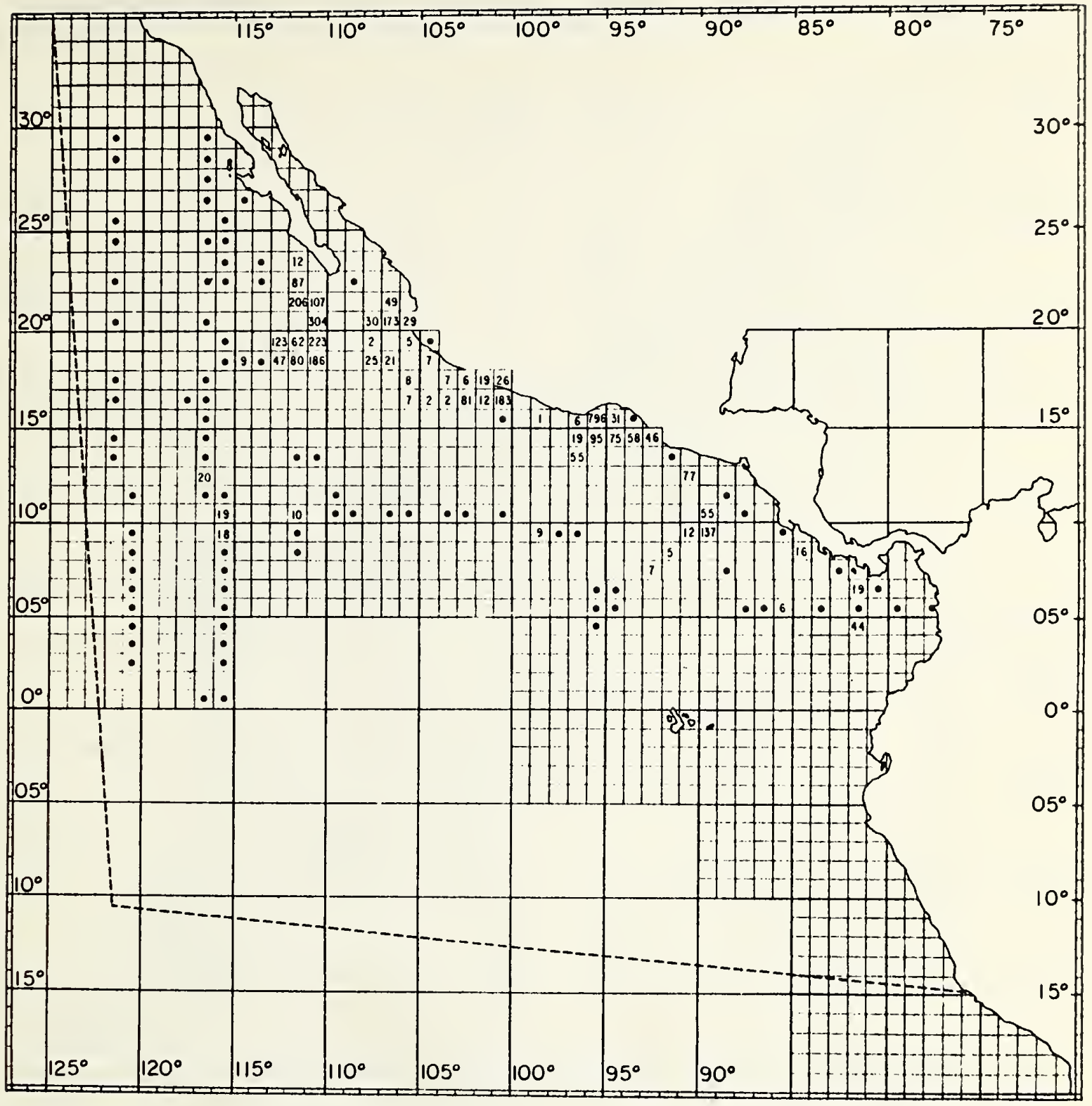

Figure 12.-Relative abundance (number of larvae per 1,000 $\mathrm{m}^{3}$ of water strained at the surface) of Auxis in May-October, based on plankton collections made in the eastern tropical Pacific. Dashed lines enclose area under investigation by Inter-American Tropical Tuna Commission in 1952-59; black dots indicate positions of plankton hauls with zero catches. (Klawe 1963.)

Table 9.-Average number of Auxis larvae caught per hour during different months off Cape Blanco, Costa Rica, with a $1 \mathrm{~m}$ (silk or nylon) net towed at $1.0 \mathrm{~m} / \mathrm{x}$ (Klawe 1963).

\begin{tabular}{lc|lc}
\hline $\begin{array}{c}\text { Month } \\
\text { capture }\end{array}$ & $\begin{array}{c}\text { Number of } \\
\text { larvae }\end{array}$ & $\begin{array}{c}\text { Month of } \\
\text { capture }\end{array}$ & $\begin{array}{c}\text { Number of } \\
\text { larvae }\end{array}$ \\
\hline January & 7.6 & July & 0.2 \\
February & 1.0 & August & 0.9 \\
March & 21.7 & September & 3.5 \\
April & 18.3 & October & 0.1 \\
May & 3.8 & November & 1.3 \\
June & 0.5 & December & 6.0 \\
\hline
\end{tabular}

From the central Pacific, there is evidence that Auxis spawn not only in waters around the Hawaiian Islands but also to the west and south of these islands. The pres- ence of small larvae of $3 \mathrm{~mm}$ or less in plankton samples indicated that spawning probably occurred in these waters just a few days prior to sampling (Table 10) (Matsumoto 1958; Strasburg 1959). Further evidence of spawning has been reported by Yoshida and Nakamura (1965), who observed that among the fish landed from schools of $A$. thazard and $A$. rochei fished by pole and line off Kaena Point, Oahu, milt was flowing from the vent of males of both species. The females, however, showed no signs of free-flowing eggs even after pressure was applied to the abdomen externally. Subsequent examination revealed that the females had ovaries that were flaccid, translucent, and grayish such as those usually seen in spent females of yellowfin tuna (June 1953). 


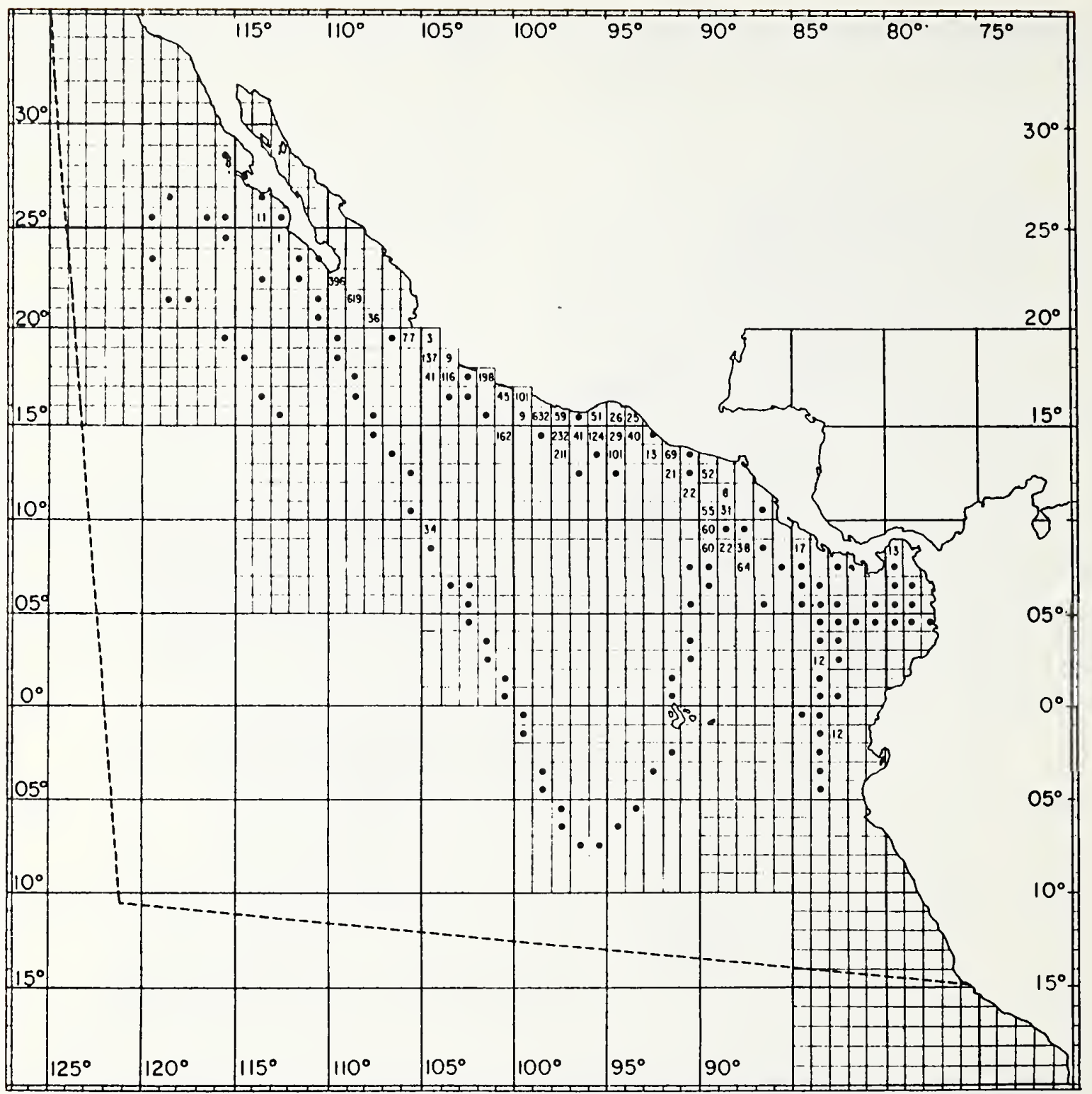

Figure 13. - Relative abundance (number of larvae per $1,000 \mathrm{~m}^{3}$ of water strained at the surface) of Auxis in November-April, based on plankton collections made in the eastern tropical Pacific. Dashed lines enclose area under investigation by Inter-American Tropical Tuna Commission in 1952-59; black dots indicate positions of plankton hauls with zero catches. (Klawe 1963.)

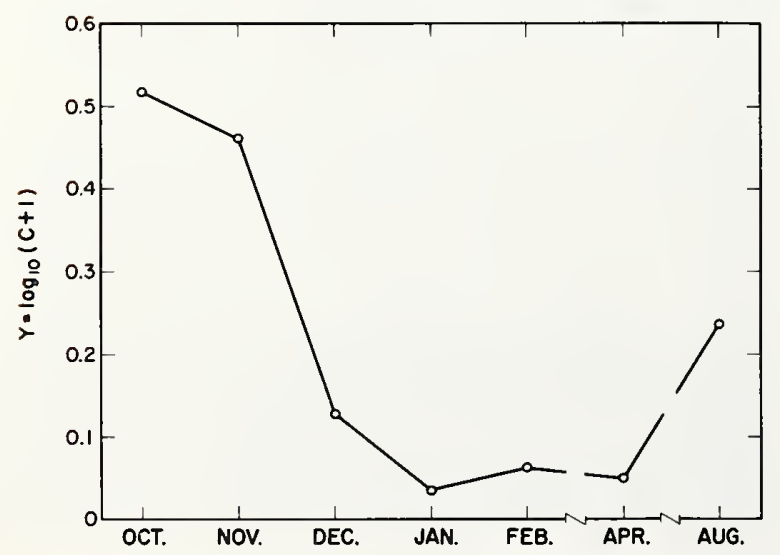

Figure 14.-Average monthly catches, $\log _{10}$ (number caught $=1$ ), of larva Auxis during cruises in October-February, April, and August to the entrance of the Gulf of California (Klawe et al. 1970).

Auxis have also been reported to spawn in waters around the Marquesas Islands (Nakamura and Matsumoto 1967). From samples of tuna larvae collected at the diel variability station (station occupied for 24-h periods), Nakamura and Matsumoto found that skipjack tuna, Katsuwonus pelamis, larvae were most numerous followed by Auxis larvae. Because currents around the Marquesas Islands are suspected to be weak, Auxis larvae as well as those of other tunas could not have drifted very far from the spawning site; therefore, 
Table 10.-Number and size range of larval Auxis thazard ( $3 \mathrm{~mm}$ or less) collected in l-h horizontal hauls (three $1 \mathrm{~m}$ nets towed simultaneously at different depths) and 30 -min oblique hauls (surface to $200 \mathrm{~m}$ ) by the RV Hugh M. Smith in Hawaiian and equatorial waters (Matsumoto I958).

\begin{tabular}{|c|c|c|c|c|c|}
\hline $\begin{array}{c}\text { Cruise and } \\
\text { station number }\end{array}$ & Date & $\begin{array}{l}\text { Time tow } \\
\text { started }\end{array}$ & $\begin{array}{l}\text { Depth of } \\
\text { haul }(\mathrm{m})\end{array}$ & $\begin{array}{c}\text { Number of } \\
\text { larvae }\end{array}$ & $\begin{array}{l}\text { Size range } \\
(\mathrm{mm})\end{array}$ \\
\hline \multirow{2}{*}{\multicolumn{6}{|c|}{$\begin{array}{l}\text { Hawaiian waters: } \\
\text { Cruise } 6 \text { : }\end{array}$}} \\
\hline & & & & & \\
\hline No. $1 \mathrm{~A}$ & 25 Aug. 1950 & 1405 & $0,50,150$ & 1 & 3.6 \\
\hline No. 7 & 27 Aug. 1950 & 1853 & $0,50,150$ & 1 & 6.2 \\
\hline No. 8 & 28 Aug. 1950 & 0507 & $0,100,200$ & 4 & $2.5-8.2$ \\
\hline No. 10 & 24 Aug. 1950 & 2239 & $0,150,300$ & 10 & $2.7-3.7$ \\
\hline No. 11 & 25 Aug. 1950 & 0500 & $0,50,150$ & 2 & $7.02,8.1$ \\
\hline No. 13 & 24 Aug. 1950 & 0528 & $0,50,150$ & 12 & $3.0-5.2$ \\
\hline Total & & & & 30 & $2.5-8.2$ \\
\hline \multirow{2}{*}{\multicolumn{6}{|c|}{$\begin{array}{l}\text { Equatorial waters: } \\
\text { Cruise } 5 \text { : }\end{array}$}} \\
\hline & & & & & \\
\hline No. 21 & 9.July 1950 & 0143 & $0-200$ & 2 & 2.6 \\
\hline No. 51 & 5 Aug. 1950 & 2300 & $0-200$ & 2 & $4.2,5.5$ \\
\hline \multicolumn{6}{|l|}{ Cruise 14: } \\
\hline No. 26 & 1 Feb. 1952 & 1920 & $0-200$ & 1 & 3.6 \\
\hline No. 29 & 19 Feb. 1952 & 2008 & $0-200$ & 1 & 3.1 \\
\hline \multicolumn{6}{|l|}{ Cruise 15: } \\
\hline No. 3 & 29 May 1952 & 0315 & $0-200$ & 1 & 7.2 \\
\hline \multicolumn{6}{|l|}{ Cruise 18: } \\
\hline No. 31 & 9 Nov. 1952 & 2329 & $0-200$ & 1 & 4.0 \\
\hline Total & & & & 8 & $2.6-7.2$ \\
\hline
\end{tabular}

Figure 15.-Localities of capture of larval and postlarval Auxis in Philippine waters (wade 1951).

it is reasonable to assume that Auxis spawning occurs throughout Marquesan waters.

The western Pacific also has a number of probable spawning areas. Figure 15 shows the locations where larval and postlarval Auxis (4.2-11.6 mm) were captured in plankton tows in Philippine waters. Wade (1951) noted that Auxis larvae were most abundant in JanuaryMarch whereas they were scarce the remainder of the year. Furthermore, by examining the time of capture of juvenile Auxis in fish traps and nets close to shore, Wade determined that small juveniles first appear on the market in late November, become abundant in January-February, then become scarce so that after May there were none. From these observations, he concluded that adult Auxis spawn in protected, more or less shallow areas, fairly close to land, that the main spawning season is during the winter months, and that scattered spawning takes place the remainder of the year.

Other western Pacific spawning sites include waters around Australia and Japan and the Celebes and South China Seas. The Tasman Sea off Sydney, Australia, where larval Auxis (sizes not given) have been captured, is reported to be a possible spawning site (Fig. 16). Spawning also appears to be of significant intensity in the Gulf of Tonkin (Gorbunova 1965b). Whitley (1964) reported that larval and juvenile Auxis are common in the Tasman Sea. Two types of Auxis larvae were identified from the collection made by the Dana Expedition in 1929 (Matsumoto 1959, append. table 2); these specimens probably represent $A$. thazard and $A$. rochei. According to Whitley (1964), similar specimens were washed up on Collaroy Beach in August-September

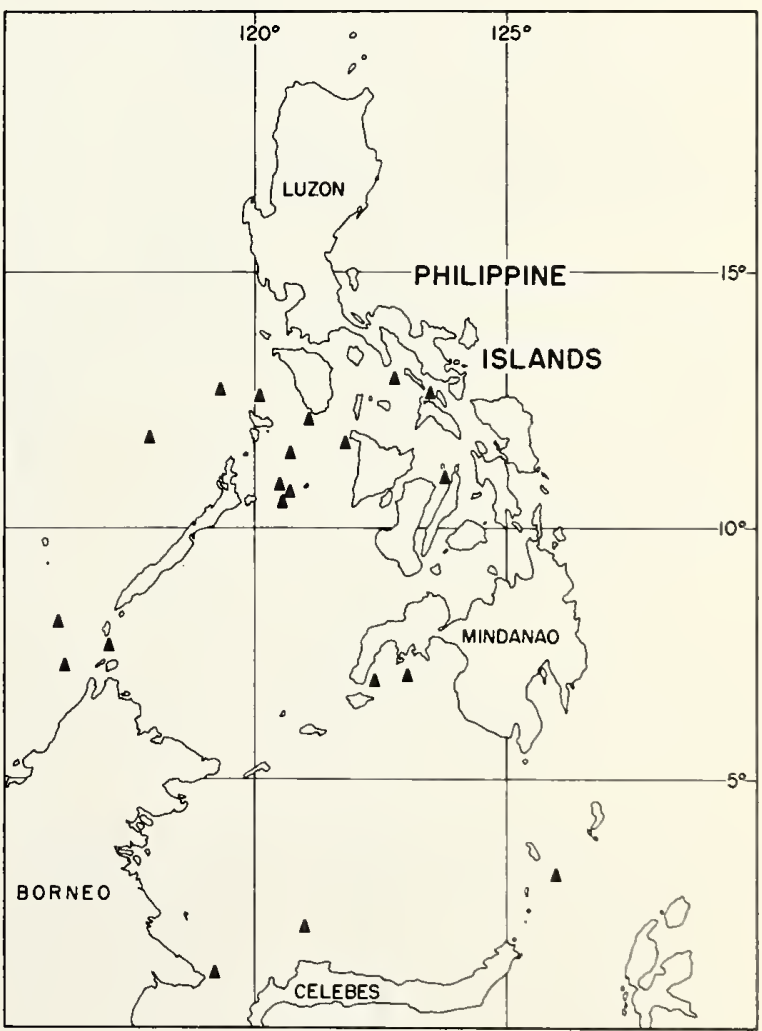

1958. The presence of larval and juvenile $A$ uxis in waters of the Tasman Sea would indicate that adult Auxis also spawn in this region of the Pacific.

In Japanese waters, $A$. rochei with ripening gonads are caught in April-June, whereas those with ripe and 


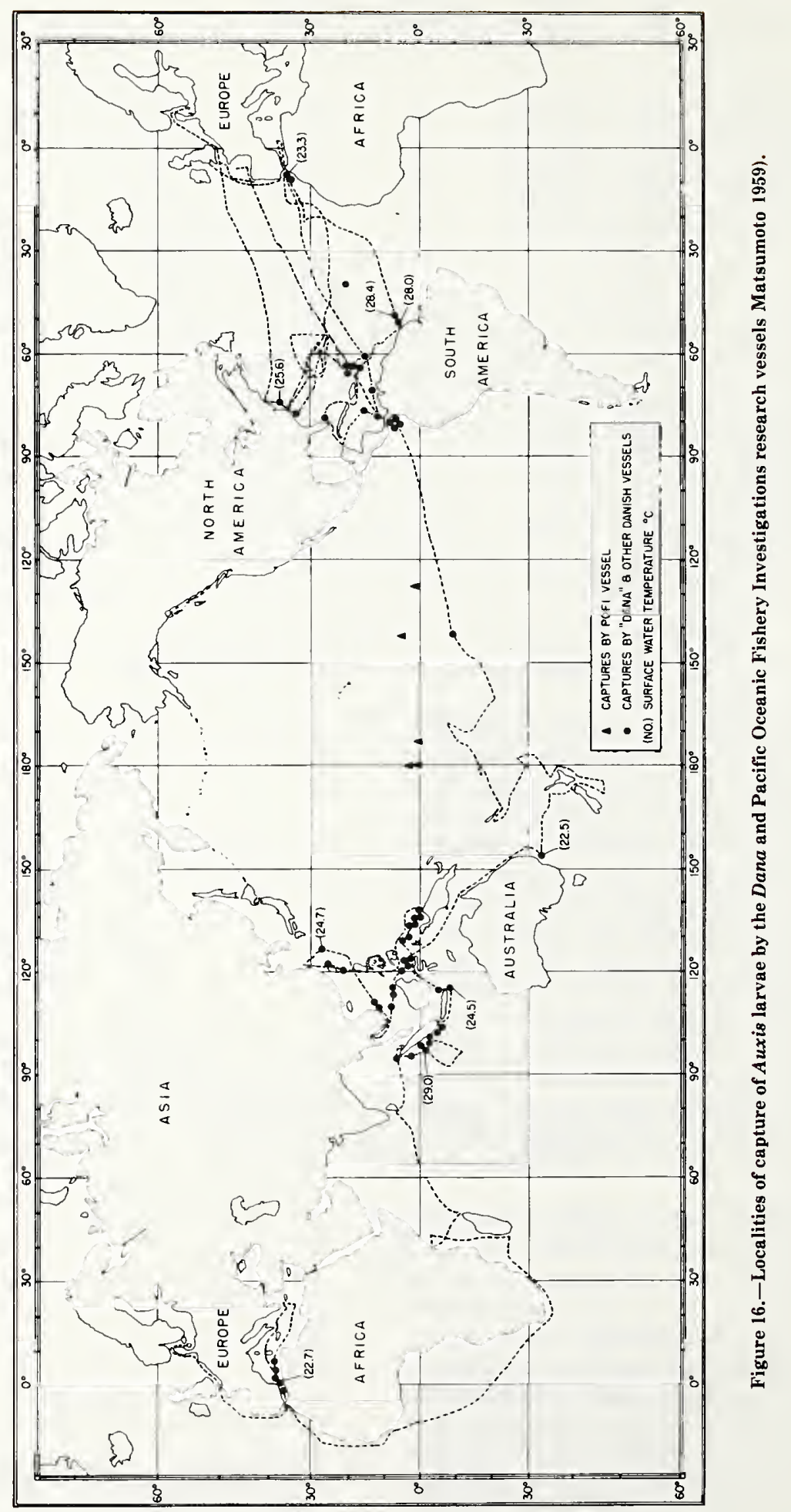


spent gonads were taken in June-July and July-August, respectively (Suzuki and Morio 1957). This was confirmed by Hamada, Morita, Ishida, and Takezawa (1973), who examined the gonad condition factors of $A$. rochei caught in waters off Kochi Prefecture and sug. gested that spawning took place in late June. They also examined the gonad condition of $A$. rochei taken off Taiwan in June-July and found that the gonad index was very high indicating perhaps that spawning was imminent. Concerning the larvae, Yabe and Ueyanagi (1962) collected those of $A$. rochei from May through July near Japan whereas Yokota et al. (1961) obtained larval $A$. rochei, measuring 3-5 mm TL (total length), from south of Shikoku and Kyushu in June-August but most were taken in July. Farther south, however, in the Celebes and South China Seas, larval $A$. rochei were collected predominantly during January and February (Yabe and Ueyanagi 1962).

It has also been established that Auxis spawn in the Indian Ocean (Bogorov and Rass 1961) and that spawning extends for at least 8 months from August to April; however, there is no information on their spawning activity for the rest of the year. Among the tuna larvae collected by the Dana Expedition from south of the equator between lat. $3^{\circ}$ and $24^{\circ} \mathrm{S}$ at long. $50^{\circ} \mathrm{E}$, Jones and Kumaran (1963) found 131 larval $A$. thazard, indicating that this species spawned in this area in DecemberJanuary. North of the equator in the Laccadive Sea, they also found larval $A$. thazard in the samples indicating a spawning period in January-April, slightly later in the year than in the south. Rao (1964) added that among samples of $A$. thazard he collected from commercial landings, the percentage of maturing and mature ovaries was highest in March. In August and September, the majority of the fishes examined were actually in spawning condition and some individuals completely spent. Samples obtained subsequently in November contained only spent fish.

Although evidence indicates that $A$. thazard spawn in the Indian Ocean, present data concerning spawning of $A$. rochei are still too meager to draw definite conclusions. Jones and Kumaran (1963) found 20 larval $A$. roche $i$ in the Dana collection from the Indian Ocean. All were collected in December-January from three locations between Madagascar and the African coast. Matsumoto (1959), who examined the collection made by the Dana from the eastern Indian Ocean southwest of the Sunda Archipelago in August-November, recognized the presence of two types of Auxis larvae. Gorbunova (1963) confirmed Matsumoto's observations, reporting that two types of Auxis larvae were distinguished in the Soviet collection made in the Indian Ocean. From the information available, Jones and Kumaran (1963) hypothesized that low latitudinal areas of the eastern Indian Ocean southwest of the Sunda Archipelago and the western Indian Ocean between Madagascar and the coast of Africa are possible spawning grounds of $A$. rochei. Gorbunova $(1965 \mathrm{a}, 1965 \mathrm{c}) \mathrm{col}-$ lected $A$. thazard larvae of $5-11 \mathrm{~mm}$ in February and March in the Bay of Bengal.
In the Atlantic Ocean, tuna larvae have been collected off the west coast of Africa, mainly in the region of Dakar at the western tip of Africa, and off Takoradi in the Gulf of Guinea (Kazanova 1962; Richards 1969). Among the various species of larval tuna and tunalike fishes collected, those identified as Auxis were most numerous. Kazanova had at his disposal a series of Auxis larvae some as small as $3 \mathrm{~mm}$. Furthermore, in addition to larvae identified as $A$. thazard, there were others which were similar to $A$. thazard but differing in some characteristics. Kazanova referred to them as the second of the two groups (Type II of Matsumoto 1959) of Auxis larvae. Therefore, it can be inferred that these regions of the Atlantic are also spawning grounds of the two species of Auxis.

Certain areas in the Mediterranean Sea have also been suggested as possible spawning sites of Auxis sp. Ehrenbaum (1924) reported Auxis spawning from July to September in the Mediterranean. Off Greece, spawning of Auxis was also reported to occur from June to September and in the Gulf of Catania (Sicily) in June and July (Belloc 1954). Declerc et al. (1973) reported capturing recently hatched larvae of Auxis in waters surrounding the Balearic Islands, located off the Mediterranean Spanish coast. In August-September 1971, 140 larval Auxis were captured by the RV Ichthys and in June-July 1972, an additional 52 Auxis larvae were taken. According to the authors, larval Auxis was the most abundant among the tuna larvae captured which included Thunnus thynnus, $T$. alalunga, and Sarda sp. The presence of the planktonic stages of all these tuna species in the plankton-net catches provided evidence that these species spawned in waters near the Balearic Islands.

The waters around Tunisia have yielded Auxis in a mature state, and this bit of evidence has led Postel (1964) to believe that spawning probably takes place in Tunisian waters. Postel examined the gonads of Auxis caught in madragues (traps) off Tunisia, found them mature, and concluded that spawning occurs in JuneAugust. For Auxis that were taken off Algeria, Postel also determined that they spawn there probably in August. Off the northwestern coast of Africa, Cape Verde Islands and Dakar have been mentioned as spawning sites of Auxis (Frade and Postel 1955; Kazanova 1962). Gorbunova (1965c) reported capturing about 600 Auxis larvae at one station in the Gulf of Aden.

In the western Atlantic, the Gulf of Mexico appears to be a large spawning ground for Auxis. Hayasi (1972) reported collecting tuna larvae identified as yellowfin, bigeye, skipjack, and Auxis in gulf waters (Fig. 17). Klawe and Shimada (1959), who collected juvenile Auxis in March-April and in June-August from a large number of stations spread widely over the Gulf of Mexico, stated that the north central gulf region is definitely a spawning locality for this species. The area southeast of the Mississippi River Delta is another possible spawning site because most of the larvae were captured there, but Klawe and Shimada pointed out that the collection 


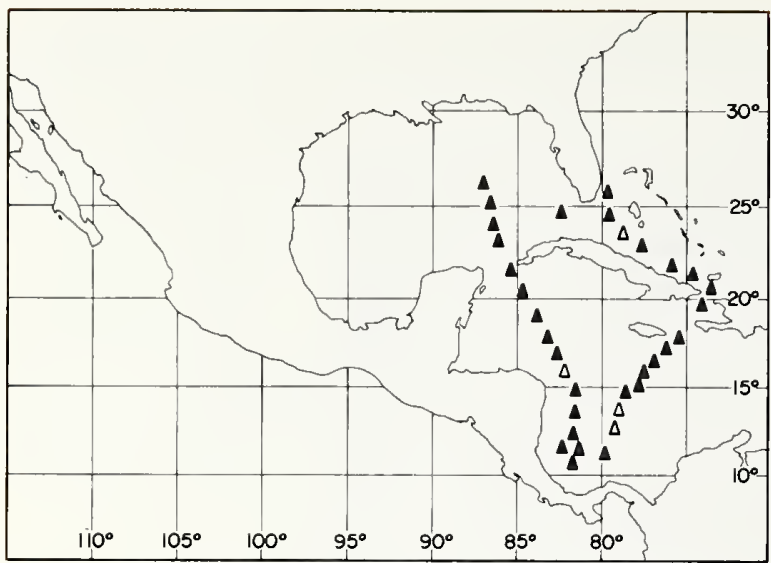

Figure 17.-Plankton stations occupied during cruises of the RV Shoyo Maru in 1969-70. Solid triangles represent stations at which Auxis larvae were collected. (Hayasi 1972.)

may reflect sampling intensity rather than actual distribution of young Auxis. In waters adjacent to the gulf extending from Cape Hatteras to Cuba and particularly in the Strait of Florida, larval Auxis have shown up in collections made in February-March (Tibbo and Beckett 1972) and in May-June and in August (Klawe 1961) indicating the possibility that spawning occurred during these months in this region.

\subsection{Spawn}

The eggs of Auxis are pelagic. Rao (1964), who examined ovaries of $A$. thazard from the Indian Ocean, observed that ripe eggs flowed freely out of the ovaries when slight pressure was applied on the abdomen. Fresh ripe eggs were perfectly spherical, had a colorless homogeneous yolk mass, and had an average diameter of $0.97 \mathrm{~mm}$ (range of 0.88-1.09 $\mathrm{mm}$ ). Preserved eggs were somewhat translucent and had an average diameter of $0.86 \mathrm{~mm}$ (range 0.78-0.98 $\mathrm{mm}$ ). Each ripe egg contained a fairly large, spherical, single oil globule which averaged $0.22 \mathrm{~mm}$ (range $0.21-0.22 \mathrm{~mm}$ ) in diameter.

Like other scombrids, female Auxis do not extrude all their ripe eggs during spawning. Microscopic examination by Yoshida and Nakamura (1965) of ovaries from eight $A$. thazard and five $A$. rochei caught in Hawaiian waters revealed that both species had eggs in various stages of resorption. One specimen of $A$. thazard still contained residual eggs in the lumen; their diameters varied between 0.75 and $1.30 \mathrm{~mm}$ and averaged 1.08 $\mathrm{mm}$. No free residual eggs were found in $A$. rochei. Concerning primordial eggs, two size groups-one ranging from 0.07 to $0.10 \mathrm{~mm}$ and the other from 0.17 to 0.22 $\mathrm{mm}$ in diameter-were noted in ovaries of $A$. thazard. In $A$. rochei, there was only one group of primordial eggs ranging from 0.07 to $0.08 \mathrm{~mm}$ in diameter.

The development of eggs and larvae of Auxis has been described for the two species from the Atlantic and Pacific Oceans. Mayo (1973) successfully hatched eggs of two species of Auxis collected from the Straits of
Florida and described the growth, behavior, ecology, and development of the larvae. In the Pacific, artificial fertilization of eggs and subsequent rearing of larvae were conducted by Japanese scientists and their results have been briefly discussed in section 2.41. Harada, Murata, and Miyashita (1973) and Ueyanagi et al. (1973) published the results of these tuna-rearing experiments in which fish in advanced stages of sexual maturity were used. Of three conventional fishing methods attempted, only purse seining proved effective in capturing mature yellowfin and skipjack tunas and set nets for collecting mature Auxis.

The "dry method" was used to obtain mature eggs and sperm. Mature eggs from ripe female Auxis generally oozed out when pressure was applied to the abdomen; therefore, no incision was necessary (Ueyanagi et al. 1973). The investigators then obtained mature males and applied pressure on the abdomen to force the sperm-bearing milt over the eggs. The mixture was gently stirred before any water was added.

Collected and fertilized at sea, the eggs were then transported to various laboratories to be hatched (Ueyanagi et al. 1973). Fertilized eggs of Auxis were transported to laboratories in $2-4 \mathrm{~h}$ on eight different occasions. The mortality of the eggs, which were transported in plastic bags filled with oxygen-saturated seawater, was negligible. The details of the success obtained in fertilizing and rearing both $A$. thazard and A. rochei follow.

\section{Auxis thazard}

Mature eggs of $A$. thazard caught at Mera, Shizuoka Prefecture, were collected, fertilized, and successfully hatched on five occasions between 15 July and 15 August 1971 (Ueyanagi et al. 1973). Larval rearing was most successful on the first trial when survival lasted up to 10 days. Newly hatched larvae emerged $25 \mathrm{~h}$ after fertilization and measured $2.59 \mathrm{~mm}$ TL. Heavy mortality usually occurred 4-5 days after hatching.

At Kushimoto, Wakayama Prefecture, mature eggs were collected, fertilized, and transported to the Marine Laboratory of Kinki University on three occasions in 1972 (Harada, Murata, and Miyashita 1973; Ueyanagi et al. 1973). The spherical, fertilized eggs were buoyant and varied from 0.93 to $0.98 \mathrm{~mm}$ in diameter (Fig. 18). Emerging 34-62 h after fertilization at temperature ranging between $21.4^{\circ}$ and $23.5^{\circ} \mathrm{C}$, the newly hatched larvae measured from 3.26 to $3.60 \mathrm{~mm}$ TL. On the third day after hatching, the larvae were fed rotifers, which were replaced by marine plankton, mainly copepods, on the seventh day. Twenty days after hatching, the larvae were fed several types of fish flesh. The larvae were placed in various-sized aquaria to determine the effects of tank capacity on growth and survival; the investigators found that growth was rapid in the 0.5 -ton $(500$ liter) aquarium during the first 30 days after which time the rate slowed appreciably (Table 11, Fig. 19). Maximum survival was 36 days. Larvae reared in aquaria which had capacities of 3 tons (3,000 liters) and 70 tons 
Fertilized ege of fuxis thazard (birasôda) in morula stage, $0.95 \mathrm{~mm}$ in diameter.

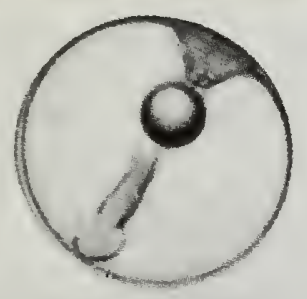

20 hours atter firtilization.

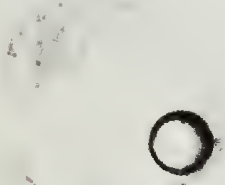

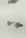

Just before hatching, 40 hours

f.rra about I diy old, $3 .+m m$ in total length.

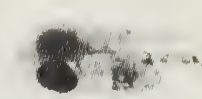

Postlarva about 5 days old.

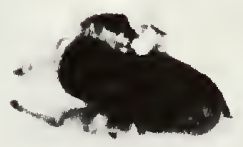

Posilarva about 10 daysold.

$$
\begin{aligned}
& \text { ヒランーダ } \\
& \text { 小化待17日 }
\end{aligned}
$$

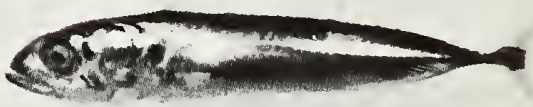

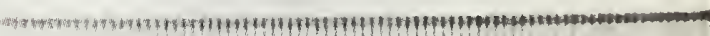

$\begin{array}{lllllll}2 & 3 & 1 & 5 & 0\end{array}$

Young lixh about 17 day's old, $6+4 m$ in total length. TL12.0. Q B Tro.6g
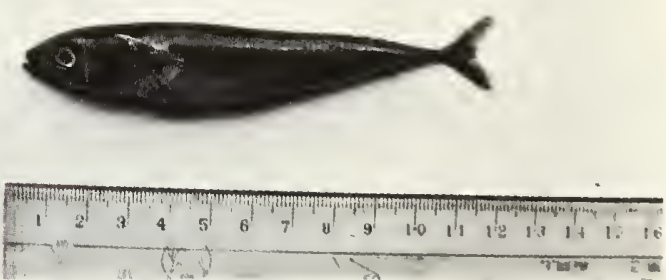

Yound hish about to days old, $12010 \mathrm{~m}$ in total length.

Figure 18.-Various stages of development of egg and larvae of Auxis thazard (Harada, Murata, and Miyashita 1973).

(70,000 liters) grew faster than those reared in the 0.5ton aquarium, reaching a length of $12 \mathrm{~cm}$ in 33 days (Table 12, Fig. 19). Growth decreased significantly after that and the last larvae died on the 41st day.
Auxis rochei

In 1972, the collection and fertilization of eggs from mature $A$. rochei succeeded in seven trials at Mera, 
Table 11.-Measurements on Auxis thazard larvae reared in a small (500 liter) aquarium (Marada, Murata, and Miyashita 1973)

\begin{tabular}{ccccc}
$\begin{array}{c}\text { Days } \\
\text { after } \\
\text { hatching }\end{array}$ & $\begin{array}{c}\text { Total } \\
\text { length } \\
(\mathrm{mm})\end{array}$ & $\begin{array}{c}\text { Fork } \\
\text { length } \\
(\mathrm{mm})\end{array}$ & $\begin{array}{c}\text { Body } \\
\text { depth } \\
(\mathrm{mm})\end{array}$ & $\begin{array}{c}\text { Body } \\
\text { weight } \\
(\mathrm{g})\end{array}$ \\
\hline 10 & 5.95 & - & 0.97 & - \\
10 & 4.90 & - & 1.10 & - \\
15 & 11.4 & - & 2.6 & - \\
20 & 29.0 & 25.0 & 5.0 & - \\
28 & 55.0 & 52.0 & 9.5 & - \\
28 & 53.5 & 50.0 & 9.0 & - \\
30 & 56.0 & 53.0 & 10.0 & - \\
30 & 47.0 & 43.0 & 9.0 & - \\
31 & 63.0 & 59.5 & 10.5 & 1.1 \\
31 & 46.0 & 43.0 & 8.5 & 1.1 \\
33 & 55.0 & 51.0 & 10.0 & 1.8 \\
33 & 55.5 & 52.0 & 9.5 & -10.0 \\
36 & 60.0 & 56.5 & & -
\end{tabular}

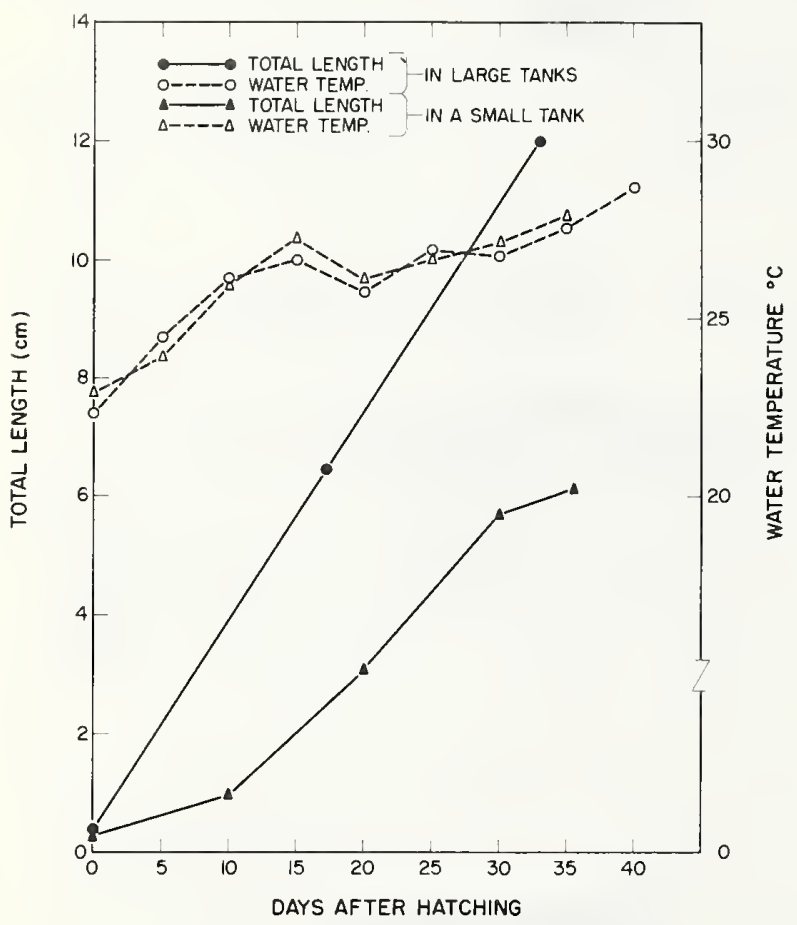

Figure 19.-Growth curves of Auxis thazard larvae reared in two large (3,000 and 70,000 liter) and one small (500 liter) aquaria. Length measurements are based on a single fish. (Harada, Murata, and Miyashita 1973.)

Table 12.-Measurements on Auxis thazard larvae reared in two large (3,000 and 70,000 liter) aquaria (Harada, Murata, and Miyashita 1973).

\begin{tabular}{ccccc}
\hline $\begin{array}{c}\text { Days } \\
\text { after } \\
\text { hatching }\end{array}$ & $\begin{array}{r}\text { Total } \\
\text { length } \\
(\mathrm{mm})\end{array}$ & $\begin{array}{c}\text { Fork } \\
\text { length } \\
(\mathrm{mm})\end{array}$ & $\begin{array}{c}\text { Body } \\
\text { depth } \\
(\mathrm{mm})\end{array}$ & $\begin{array}{r}\text { Body } \\
\text { weight } \\
(\mathrm{g})\end{array}$ \\
\hline 0 & 3.47 & - & 0.66 & - \\
2 & 3.8 & - & 0.78 & - \\
17 & 64.0 & - & 7.5 & 1.8 \\
33 & 120.0 & 112.0 & 18.0 & 10.6 \\
33 & 89.0 & 84.0 & 14.0 & 5.5 \\
33 & 120.0 & 115.0 & 18.0 & 10.6 \\
\hline
\end{tabular}

Shizuoka Prefecture (Ueyanagi et al. 1973). In one experiment, the larvae, which were fed rotifers, copepods, larvae of sea bream and goby, chopped bivalve meat, and chopped fish flesh, survived up to 67 days after fertilization.

In other rearing trials of $A$. rochei conducted at the Shirahama Fisheries Laboratory of Kinki University, Wakayama Prefecture, in June 1972, about 40,000 eggs were collected from mature females caught in a trap net near Oshima Island by Cape Shionomisaki, fertilized, and transported to the laboratory (Harada, Murata, and Furutani 1973). The buoyant, spherical fertilized eggs, which measured between 0.97 and $0.99 \mathrm{~mm}$ in diameter (Fig. 20), hatched 38-52 $\mathrm{h}$ later at temperatures ranging from $21.4^{\circ}$ to $23.5^{\circ} \mathrm{C}$. The newly hatched larvae ranged from 3.3 to $3.6 \mathrm{~mm}$ TL. Fed the same diet as that given larvae of $A$. thazard as previously described and confined in one small 0.5-ton aquarium and two large aquaria of 3 - and 30 -ton $(30,000$ liter) capacities, the larvae of $A$. rochei, like those of $A$. thazard, grew faster in the large aquaria than in the small aquarium (Tables 13, 14; Fig. 21).

Table 13.-Measurements on Auxis rochei larvae reared in a small (500 liter) aquarium (Harada, Murata, and Furutani 1973).

\begin{tabular}{rrrrr}
\hline $\begin{array}{c}\text { Days } \\
\text { after } \\
\text { hatching }\end{array}$ & $\begin{array}{r}\text { Total } \\
\text { length } \\
(\mathrm{mm})\end{array}$ & $\begin{array}{c}\text { Fork } \\
\text { length } \\
(\mathrm{mm})\end{array}$ & $\begin{array}{r}\text { Body } \\
\text { depth } \\
(\mathrm{mm})\end{array}$ & $\begin{array}{r}\text { Body } \\
\text { weight } \\
(\mathrm{g})\end{array}$ \\
\hline 0 & 3.49 & - & 0.62 & - \\
2 & 3.58 & - & 0.70 & - \\
10 & 5.18 & - & 1.05 & - \\
15 & 7.10 & - & 1.70 & - \\
15 & 6.65 & - & 1.15 & - \\
15 & 8.50 & - & 1.95 & - \\
15 & 9.10 & - & 2.25 & - \\
20 & 11.00 & - & 2.70 & - \\
20 & 9.95 & - & 2.50 & - \\
20 & 8.50 & - & 2.35 & - \\
20 & 9.50 & - & 2.60 & 7.0 \\
43 & 95.00 & 89.00 & 14.00 & 6.2 \\
43 & 89.00 & 85.00 & 15.00 & \\
\hline
\end{tabular}

Table 14.-Measurements on Auxis rochei larvae reared in two large (3,000 and 30,000 liter) aquaria (Harada, Murata, and Furutani $1973)$.

\begin{tabular}{rrrrr}
\hline $\begin{array}{c}\text { Days } \\
\text { after } \\
\text { hatching }\end{array}$ & $\begin{array}{c}\text { Total } \\
\text { length } \\
(\mathrm{mm})\end{array}$ & $\begin{array}{c}\text { Fork } \\
\text { length } \\
(\mathrm{mm})\end{array}$ & $\begin{array}{c}\text { Body } \\
\text { depth } \\
(\mathrm{mm})\end{array}$ & $\begin{array}{c}\text { Body } \\
\text { weight } \\
(\mathrm{g})\end{array}$ \\
\hline 0 & 3.49 & - & 0.62 & - \\
2 & 3.58 & - & 0.73 & - \\
18 & 49.00 & - & 7.70 & 0.8 \\
36 & 88.00 & 82.0 & 18.00 & 4.2 \\
40 & 140.00 & 120.0 & 30.00 & 25.0 \\
51 & 152.00 & 142.0 & 32.00 & 32.5 \\
51 & 144.00 & 138.0 & 24.00 & 21.9 \\
51 & 152.00 & 143.0 & 28.00 & 28.2 \\
52 & 145.00 & 136.0 & 26.00 & 24.0 \\
52 & 157.00 & 152.0 & 28.00 & 37.0 \\
52 & 155.00 & 145.0 & 26.00 & 31.7 \\
58 & 120.00 & 112.0 & 18.00 & - \\
58 & 155.00 & 145.0 & 30.00 & - \\
\hline
\end{tabular}




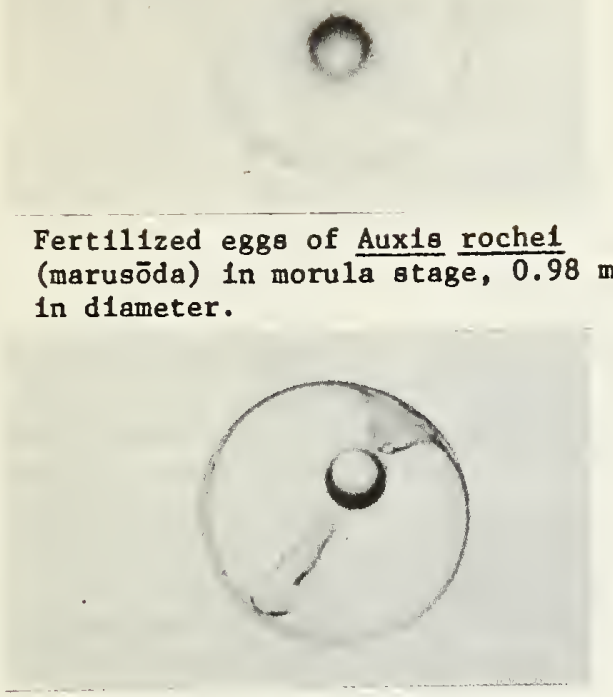

20 hours after fertilization.

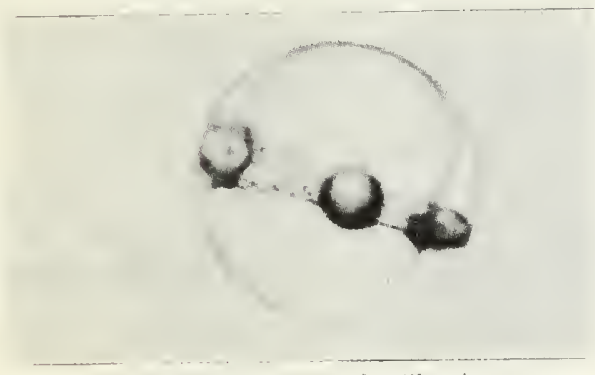

28 hoursater fertilization.

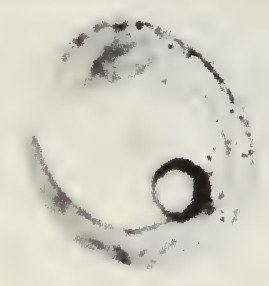

Just before hatching, 38 hours.

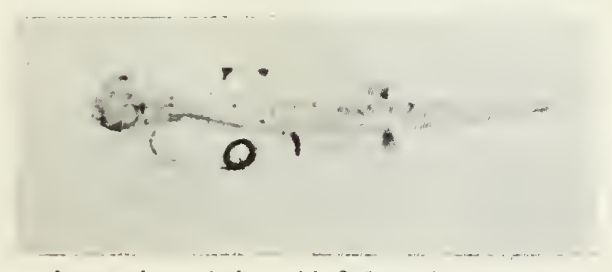

Larva about 1 day old, $3.5 \mathrm{~mm}$ in total lengtlt.

\section{s}

Postlarva about 5 daysold.

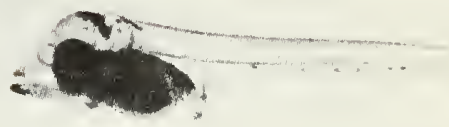

Postlarva ibsut lo days old.

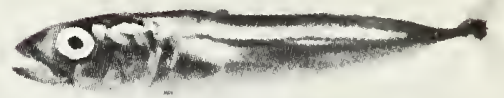

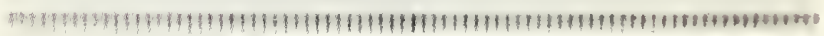

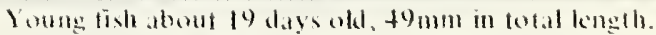

$$
\text { situmition }
$$
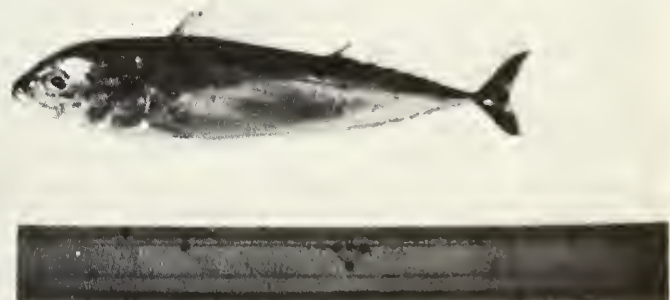

lmm.ature fish about 52 days ohd. $157 \mathrm{~mm}$ in tol.al lengll

Figure 20.-Various stages of development of egg and larva of Auxis rochei (Harada, Murata, and Furutani 1973).

Experiments on artificial fertilization were continued in 1973 . On 15 July 1973 , at 0500 , ripe eggs were collected from $A$. rochei caught in a set net off Kashino, Oshima (Kushimoto, Wakayama Prefecture), and artificially fertilized (Kinki University Fisheries Experi- mental Station 1974). The water temperature at the time of fertilization was $25^{\circ} \mathrm{C}$. The fertilized eggs, which averaged $0.903 \mathrm{~mm}$ in diameter, were transported to the experimental station at Shirahama. The following day, an estimated 7,000 newly hatched larvae were placed in 


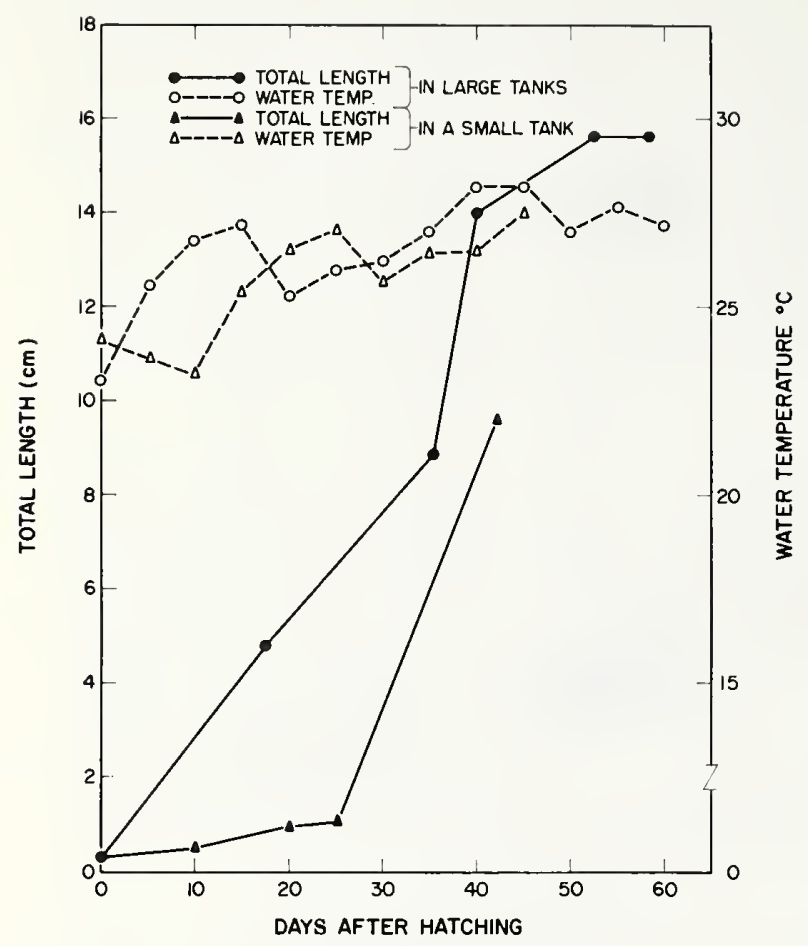

Figure 21.-Growth curves of Auxis rochei larvae reared in two large (3,000 and 30,000 liter) and one small (500 liter) aquaria. Length measurements are based on a single fish. (Harada, Murata, and Furutani 1973.)

a 3-ton aquarium and at age 2 days were fed rotifers and marine plankton. By age 18 days, the larvae were $3 \mathrm{~cm}$ long. From the 24 th day, the larvae were fed minced fish flesh, and they grew rapidly, reaching $5-6 \mathrm{~cm}$ by the $27 \mathrm{th}$ day; however, heavy mortality reduced the number of larvae to 36 . By the 35 th day, the survivors were 7.7-7.9 $\mathrm{cm}$ long. Only one larva survived for 50 days. The Japanese investigators observed that this rate of growth was slower than in previous experiments and believed that it was due to lack of fish larvae as food. They emphasized, however, that the experiments succeeded in artificially producing "seedlings" of $A$. rochei which were several centimeters in length.

In general, then, these experiments on frigate and bullet tunas have shown that:

1. the eggs are buoyant, spherical, and measure between 0.93 and $0.99 \mathrm{~mm}$ in diameter;

2 . the eggs hatch from 34 to $62 \mathrm{~h}$ after fertilization in water temperatures ranging between $21.4^{\circ}$ and $23.5^{\circ} \mathrm{C}$;

3. the newly hatched larvae measure 3.26 and $3.60 \mathrm{~mm}$ TL;

4. the larvae can be fed rotifers, copepods, and minced fish flesh, in that order, after hatching;

5. the growth and survival rates of larvae are better in large rather than in small aquaria; and that

6. under the best conditions, $A$. thazard larvae grew 120 $\mathrm{mm}$ in 33 days whereas $A$. roche $i$ larvae grew $157 \mathrm{~mm}$ in 52 days.

\subsection{Preadult phase}

\subsection{Embryonic phase}

See section 3.17 above.

\subsection{Larval phase}

Studies of anatomical development of larval Auxis show that gross nucleation of the central nervous system of young Auxis (3.6-23.0 mm SL) is similar to young Thunnus albacares but heavier than in Katsuwonus pelamis, $T$. obesus, $T$. thynnus, $T$. alalunga, $T$. atlanticus, and Euthynnus alletteratus (Richards and Dove 1971). Using sectioned organs and tissues, Richards and Dove determined that the swim bladder in katsuwonus and Auxis, which, among scombrids is similar in the very early stages of development, starts to degenerate when the larvae reach the size of $9 \mathrm{~mm}$, and is nearly completely degenerated in specimens $24 \mathrm{~mm}$ long at which time only the gas gland remains. Richards and Dove also determined that in Auxis the kidney is short until the larvae reach $11 \mathrm{~mm}$ after which it lengthens significantly and that the postcardinal vein is larger in Auxis and Euthynnus than in other species.

The criteria for specific identification and separation of Auxis larvae from those of other tuna and tunalike fishes appear to be quite well established. Ueyanagi (1964) has provided a key to identifying tuna larvae and this is given below:

\section{Key to the larvae of tunas from the western Pacific ${ }^{6}$}

a Melanophores visible on the forebrain

$b_{1}$ One conspicuous melanophore present on the caudal peduncle. No chromatophores on the isthmus or directly anterior to the anus.

.... skipjack tuna, Katsuwonus pelamis

$b_{2}$ There is a dotted line of melanophores along the midlateral line on the posterior part of the body. Chromatophores appear on the isthmus and directly anterior to the anus.

........ kawakawa, Euthynnus affinis

$a_{2}$ No melanophores visible on the forebrain.

c Melanophores appear on the sides of the body.

$d_{1}$ Chromatophores appear on the isthmus and directly anterior to the anus. Melanophores appear as dotted lines along the middorsal, midlateral, and midventral lines of the caudal region (usually in three lines).

.... frigate and bullet tunas, Auxis spp.

$\mathrm{d}_{2}$ Chromatophores do not appear on the

${ }^{6}$ Applicable to larvae under about $8 \mathrm{~mm}$ TL. 
isthmus nor directly anterior to the anus.

$f_{1}$ One or several melanophores appear along the dorsal and ventral sides of the body.

$\mathrm{g}_{1}$ The most anterior of the chromatophores on the dorsal side is located posterior to the origin of the second dorsal fin.

.......bluefin tuna, Thunnus thynnus

$\mathrm{g}_{2}$ The most anterior of the chromatophores on the dorsal side is located anterior to the origin of the second dorsal fin.

..... long-tailed tuna, Thunnus tonggol

$f_{2}$ One of several melanophores appear along the ventral side of the body.

.........bigeye tuna, Thunnus obesus

$c_{2}$ No melanophores appear on the sides of the body.

$h_{1}$ Chromatophores appear at tip of lower jaw. In the profile of the head, the center of the eye is clearly located higher than the tip of the snout. ..... yellowfin tuna, Thunnus albacares

$h_{2}$ No chromatophores appear on tip of lower jaw. In the profile of the head, the center of the eye is about on the same level as the tip of the snout or slightly higher.

........ albacore, Thunnus alalunga

Briefly, larval Auxis can be distinguished from other larvae of tuna and tunalike fishes by the presence of a dotted line of melanophores along the dorsal, lateral, and ventral center lines of the caudal peduncle (Ueyanagi 1964). The standard pattern is three lines, but sometimes only two-the dorsal and ventral-are seen. In small specimens, however, the line on the ventral side is not confined to the vicinity of the caudal peduncle but extends farther forward. Other characteristics include the appearance of melanophores on the isthmus and just anterior to the anus, late appearance of chromatophores on the forebrain (they do not appear until the fish attains a body length of about $8 \mathrm{~mm}$ ), and poorly developed chromatophores on the first dorsal fin (they do not appear until the fish becomes about $10 \mathrm{~mm}$ long). The outline of the anterior surface of the head gives an impression of roundness and the separation betweeen the first and second dorsal fins becomes quite apparant at lengths of $10 \mathrm{~mm}$ or greater.

Additional observations on the morphology of larval Auxis showed that the snout is shorter than in other tuna and tunalike larvae of comparable size (Jones 1963). Jones also noted that larval Auxis has 39 myotomes, a large chromatophore at the symphysis of the pectoral girdle, and that fin ray development is later than in other tuna and tunalike larvae. Jones and Kumaran (1964) added that compared with larval Euthynnus affinis, larval Auxis exhibits later development of the first dorsal fin and has relatively few chromatophores on the first dorsal fin membrane, and its fin membrane is relatively narrow.

The variations in pigmentation among larval Auxis has been used as a basis for separating the larvae into two possible types. Matsumoto (1959), who described the morphology of larval and postlarval Auxis on a worldwide basis, pointed out the possibility that this variation may well be due to the presence of two species of frigate tuna; therefore, he provided two separate descriptions calling them Type I and Type II, as shown in Figure 22.

Type I and Type II larvae show only minor differences and the most obvious one is the variation in pigmentation near the caudal peduncle (Matsumoto 1959). Type I, which resembles the form described as $A$. thazard (Matsumoto 1958), has three equally developed rows of pigment whereas in Type II the middorsal edge of the caudal peduncle usually contains only one or two chromatophores and the midlateral line has none.

Subsequently, Type I larvae, which are stouter than Type II, were provisionally identified as $A$. thazard and Type II, which are relatively elongate, were identified as $A$. rochei (Jones 1963). Further observations revealed that compared to $A$. thazard, larval $A$. rochei has a relatively shallow body, shows later development of the spinous dorsal, and has less intense pigmentation on the caudal peduncle (Jones 1963; Gorbunova 1969). A later study confirmed Jones' observation; Yabe and Ueyanagi (1962) published the results of a study on larval tuna in which they positively identified specimens of $A$. rochei.

A controversy over the identification of larval Auxis erupted in 1963 when Jones (1963) questioned the results obtained by Mito (1961), who described the egg and larval development of Auxis (Fig. 23). Jones pointed out that because $A$. rochei is the most common frigate mackerel in Japanese waters, the eggs and larval stages described by Mito may be this species; but he also noted that there were striking differences between larvae described by Mito and those described by Matsumoto (1959) and Jones (1961). These differences, he believed, should be explained by Mito. The breakthrough in artificial rearing accomplished by the Japanese should make it possible to compare specimens of artificially reared larvae and those obtaind from net tows and night lighting to obtain positive identification.

\subsection{Adolescent phase}

Juvenile Auxis can be distinguished from other tunas by certain morphological features (Schaefer and Marr 1948; Wade 1949; Mead 1951; Matsumoto 1962). They can be distinguished from other tunas by the wide gap between the first and second dorsal fins and the virtually colorless appearance of the first dorsal. Compared to Katsuwonus, however, the first dorsals are somewhat similar, both having a lightly pigmented or colorless fin. 

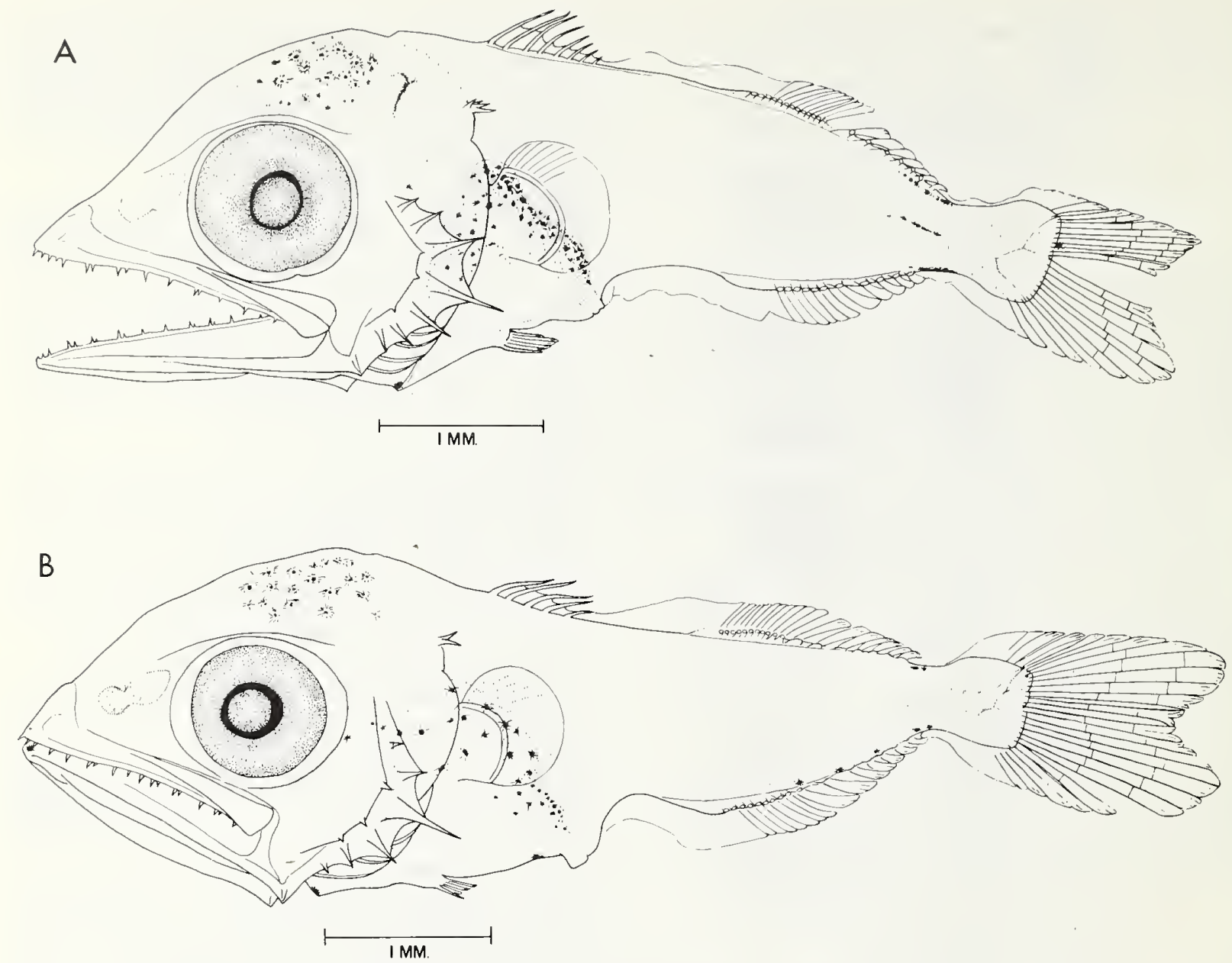

Figure 22.-Auxis larvae Type I, $7.05 \mathrm{~mm}$ (A) and Type II, $7.2 \mathrm{~mm}$ (B) (Matsumoto 1959).

Katsuwonus, nevertheless, possess more pigment in the first dorsal, which is also more or less brown or tan distally, whereas in Auxis, a few scattered chromatophores are found along several of the anterior rays in the distal portion of the first dorsal. Compared with Euthynnus, Auxis are rounder in cross section, relatively less compressed laterally, and the length of the head and the caudal region shorter in comparison to total length. Juvenile Auxis also possess a black spot at the isthmus which is seen only in one other genus, Euthynnus. In young Euthynnus, however, the first and second dorsals are continuous. The large interspace between the dorsals, the low ray count of the first dorsal, and the absence of an elaborate "trellis" of the vertebrae also help to separate Auxis from Euthynnus and Katsuwonus.

The pattern of pigmentation is also a good identifying character. Schaefer and Marr (1948) wrote "In the smaller specimens the prominent areas of pigmentation are on the upper and lower jaws, above the snout, around the postero-ventral margin of the orbit, on the upper operculum, between the orbits, along the mid-line of the body, along the bases of the dorsal and anal fins including the finlets, and around the posterior end of the urostyle. Large chromatophores in the peritoneum show through the body wall along the upper half of the body cavity. None of the fins or finlets bears pigment spots, with the exception of the first dorsal. The first dorsal bears a few scattered chromatophores, largely distributed along the spines."

Several features of the axial skeleton also are useful in separating the juveniles of partially digested tunas. Potthoff and Richards (1970), who studied regurgitated food of terns and noddies from the Dry Tortugas, Fla., observed that damaged or partly digested Auxis and those $<30 \mathrm{~mm}$ could easily be separated from Euthynnus if judged on fin position and gill raker counts. Potthoff and Richards revealed that extreme care must be used to examine Auxis specimens because the spines of the first dorsal in some juveniles are subcutaneous and come to the surface in the fin interspace. Furthermore, they noted that the number of gill rakers is evenly distributed over the range for Auxis whereas they are more normally distributed in other species. Counts were as follows: 19 in $38 \%$ of the ceratobranchials, 20 in $25 \%, 21$ in $25 \%$, and 22 in $12 \%$. Potthoff and Richards suggested that this kind of distribution may be attributable to the presence of two types of Auxis and their intermediates. 

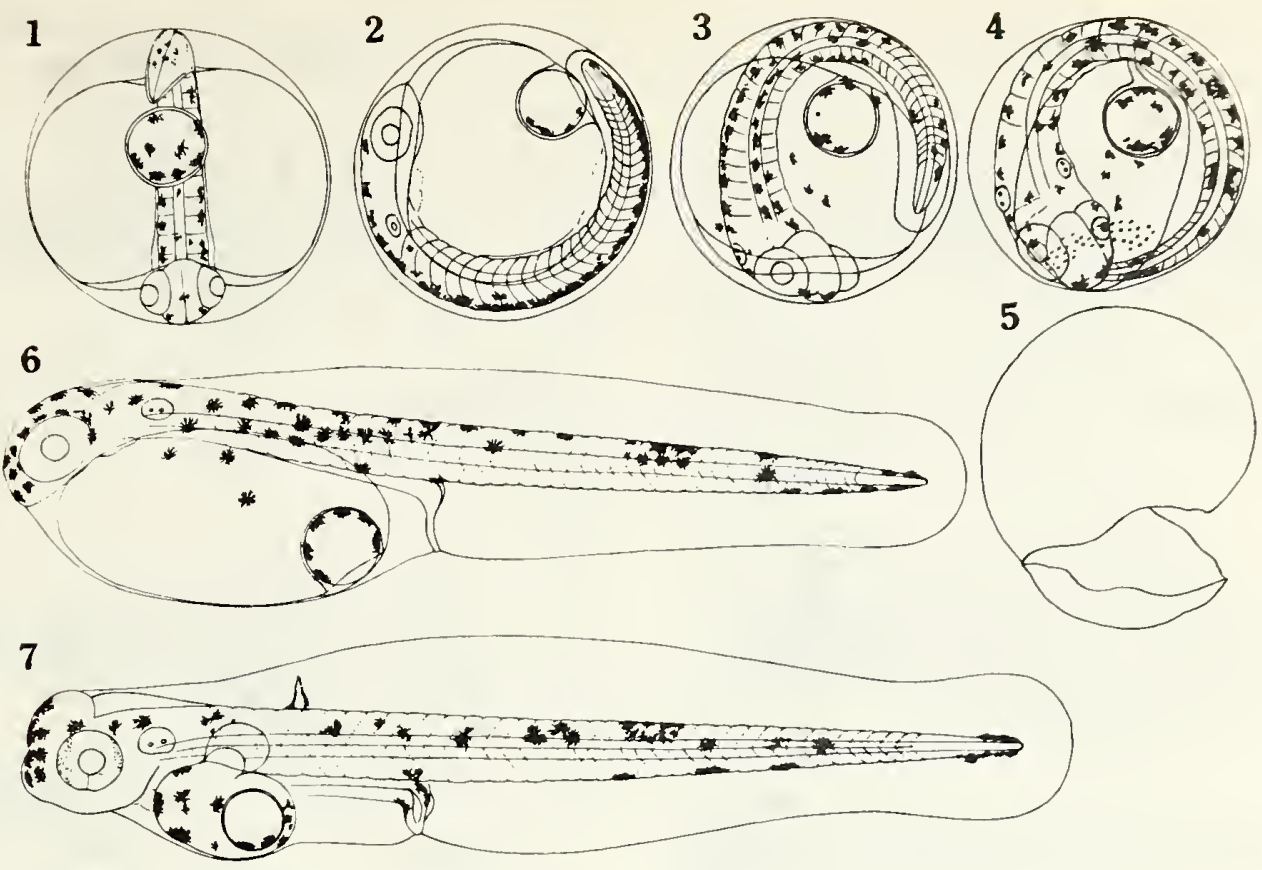

8
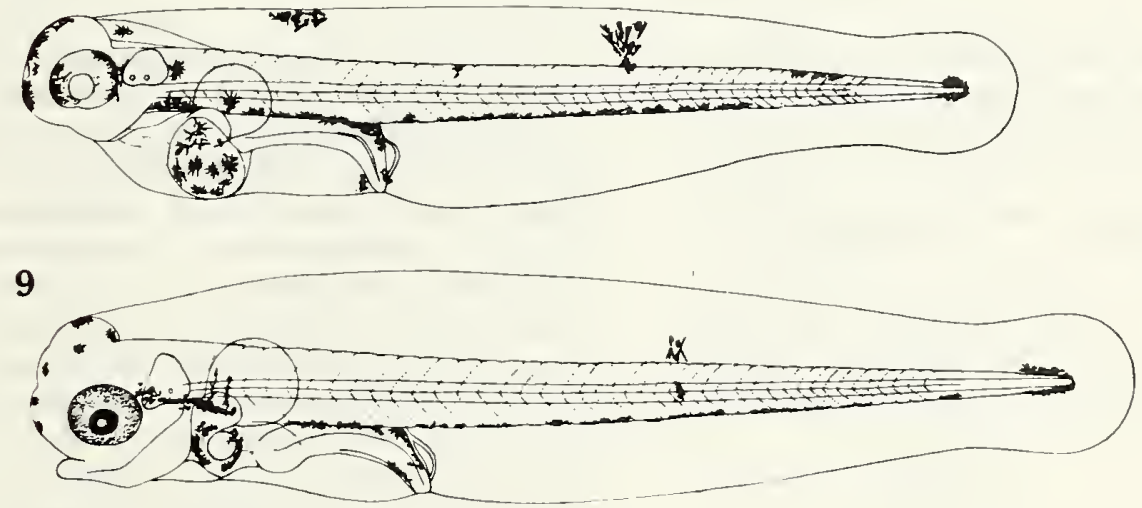

10

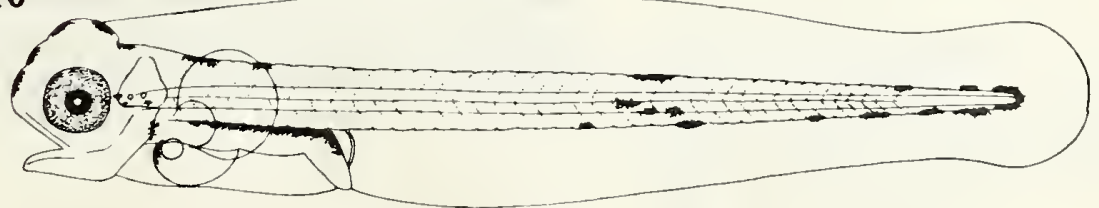

Figure 23. - Various stages of development of egg and larvae of Auxis (Mito 1961); 1 ) Pelagic egg, $7^{1 / 2} \mathrm{~h}$ after collecting, $1.04 \mathrm{~mm}$ in diameter, oil lobule $0.26 \mathrm{~mm}$; 2) 29 -myotome stage, $91 / 2 \mathrm{~h}$ after; 3) $10^{1 / 2} \mathrm{~h}$ after; 4) $14^{1 / 2} \mathrm{hr}$ after, shortly before hatching $\left.\left(24^{\circ}-27^{\circ} \mathrm{C}\right) ; 5\right)$ empty egg capsule; 6) larva just hatched, $2.70 \mathrm{~mm} \mathrm{TL}$, myotomes $11+32=43 ; 7$ ) larva $16^{1 / 2}$ h after hatching, $3.68 \mathrm{~mm}$ TL, myotomes $9+31=40 ; 8$ ) larva $30 \mathrm{~h}$ after, $3.58 \mathrm{~mm}$ TL, myotomes $9+31=40 ; 9$ ) larva $42^{1 / 2} \mathrm{~h}$ after, $3.92 \mathrm{~mm} \mathrm{TL}$, myotomes $9+32=41 ; 10$ ) larva $55 \mathrm{~h}$ after, $3.75 \mathrm{~mm}$ TL, myotomes $8+31=39$.

In addition to the gill raker counts (38-43 for $A$. thazard and 43-49 for $A$. rochei), the form of the free parapophyses is a useful feature of the axial skeleton for separating Auxis to species. Watanabe (1964) determined that in $A$. thazard, the free parapophyses are long, extend downward and almost touch the haemal spine of the preceding vertebra whereas in $A$. rochei they are short. This difference in length of the parapophyses is particularly evident on specimens of $111 \mathrm{~mm}$ or more (Figs. 24, 25).

Four other characters used by Watanabe (1964) include: 1) the number of the vertebra on which the first free parapophysis occurs, 2) the number of the vertebra on which the first inferior foramen occurs, 3 ) the ratio of the length of the caudal to the precaudal vertebra, and 4) the ratio of the body height at the origin of the anal 


\section{Auxis thazard}

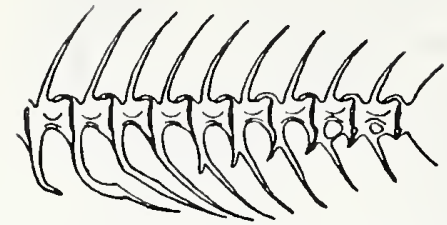

Specimen No. 7 Standard length $88.5 \mathrm{~mm}$.

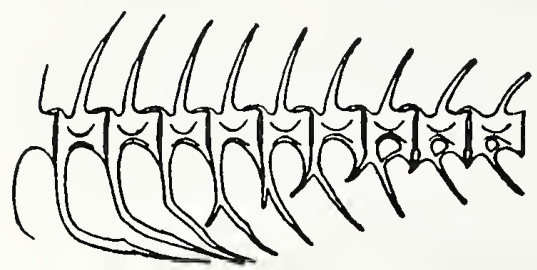

Specimen No. 23 Standard length $124.6 \mathrm{~mm}$.
Auxis rochei

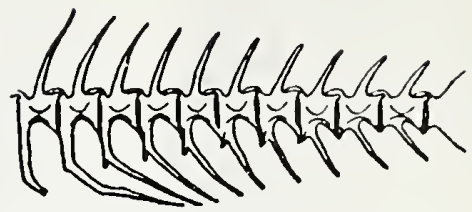

Specimen No. 28 Standard length $94.0 \mathrm{~mm}$.

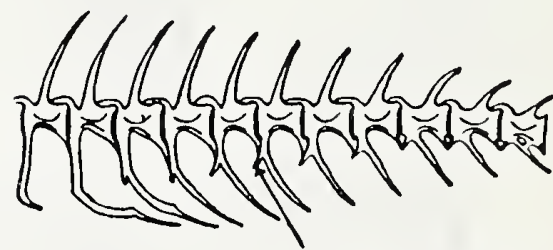

(free parapophysis)

Specimen No. 37 Standard length $123.6 \mathrm{~mm}$.

Figure 24.-Caudal vertebrae of Auxis thazard (left) and A. rochei (Watanabe 1964).

fin to the distance between the origin of the first and second dorsal fins. Watanabe found that in A. thazard, the first free parapophysis occurred most frequently on the

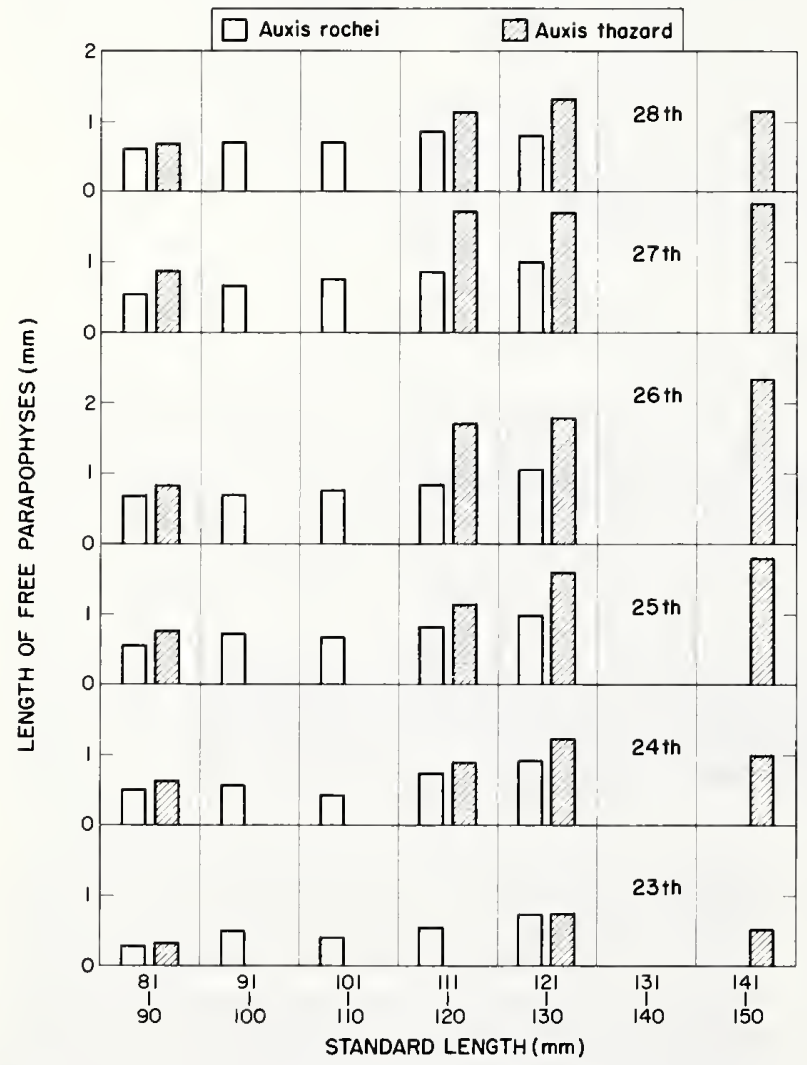

Figure 25.-Comparison of the length of the free parapophyses of the caudal vertebrae between Auxis thazard and $A$. rochei (Watanabe 1964).
$23 \mathrm{~d}$ vertebra, whereas in $A$. rochei, it was on the 21 st or $22 \mathrm{~d}$ vertebra on $80 \%$ of the specimens; however, there were some in which it occurred on the $23 \mathrm{~d}$ vertebra. Furthermore, the inferior foramen in young specimens occurs on the 27 th or 28 th vertebra in A. thazard and usually on the 29 th and 30 th vertebra in $A$. rochei. Watanabe also observed that the ratio of the length of the caudal to the precaudal vertebra for young specimens was 0.973 or less in $A$. rochei and 0.985 or more for $A$. thazard. This character also changes as growth occurs; therefore, the stage of growth needs to be considered in making a diagnosis. Figure 26 shows a plot of the ratios-body height at the origin of the anal fin to the distance between the origins of the first and second dorsal fins - on standard lengths and except for a single specimen which showed an intermediate value, those for $A$. thazard tend to be higher than for $A$. rochei.

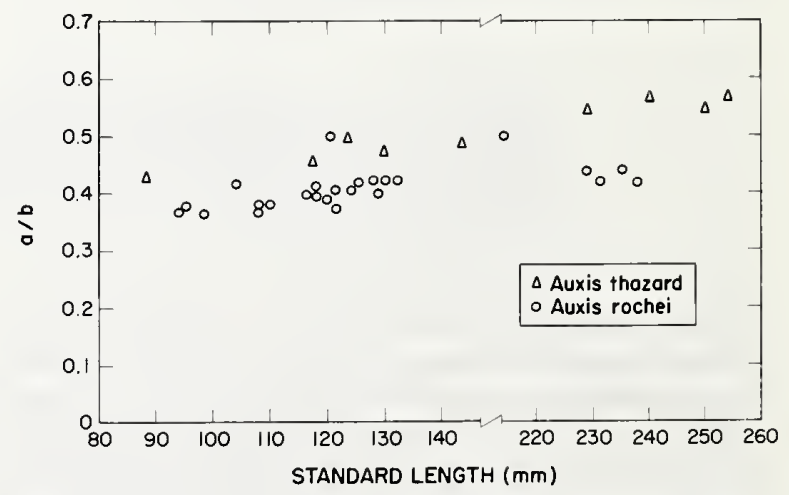

Figure 26. - Comparison of the value $(\mathrm{a} / \mathrm{b})$ between individuals of Auxis thazard and $A$. rochei (Watanabe 1964). (a = Body height at anal origin; $b=$ length of first dorsal to second dorsal origin.) 
Table 15. - Standard length and gill raker counts of juvenile $A$ uxis thazard and A. rochei (Wade 1949).

\begin{tabular}{ccr}
\hline Species & Standard length $(\mathrm{mm})$ & Gill raker count \\
\hline Auxis thazard & 21.8 & $14+1+18=23$ \\
22.6 & $10+1+30=41$ \\
26.0 & $7+1+29=37$ \\
26.0 & $10+1+31=42$ \\
43.5 & $10+1+29=40$ \\
44.0 & $8+1+29=38$ \\
46.0 & $8+1+30=39$ \\
47.0 & $9+1+29=39$ \\
47.0 & $9+1+29=39$ \\
48.0 & $9+1+29=39$ \\
49.0 & $8+1+30=39$ \\
55.0 & $9+1+29=39$ \\
32.0 & $10+1+35=46$ \\
Auxis rochei & 42.0 & $11+1+34=46$ \\
& $10+1+34=45$ \\
& 51.5 & $10+1+35=46$ \\
& $10+1+34=45$ \\
& 61.0 & $10+1+34=45$ \\
& $10+1+36=47$ \\
\hline
\end{tabular}

${ }^{1}$ Low count possibly due to the small size of the specimen and the undeveloped gill rakers.

Some investigators believe that the separation of juvenile Auxis into either $A$. thazard or $A$. rochei could be accomplished by gill raker counts alone (Table 15). In small specimens, errors in gill raker counts are possible, but in specimens $25-30 \mathrm{~mm}$ SL, no difficulty should be experienced (Wade 1949). Schaefer and Marr (1948), however, observed that in a $21 \mathrm{~mm}$ specimen, the gill rakers are very tiny projections and are difficult to count. The rakers are first apparent near the angle of the arch, but as the fish increases in size, those that are near the angle of the arch increase in length and new rakers are added distally on each arm. Schaefer and Marr judged by counts on specimens of various sizes that the full complement of rakers on A. thazard is attained at about $50 \mathrm{~mm}$ TL, but Klawe and Shimada (1959), who plotted the total gill raker counts against corresponding total lengths, found that the full complement is attained at sizes $40 \mathrm{~mm}$ or larger (Fig. 27). And Wade (1949) reported that in $A$. rochei, the full complement of gill rakers can be found in juveniles as small as $32 \mathrm{~mm}$.

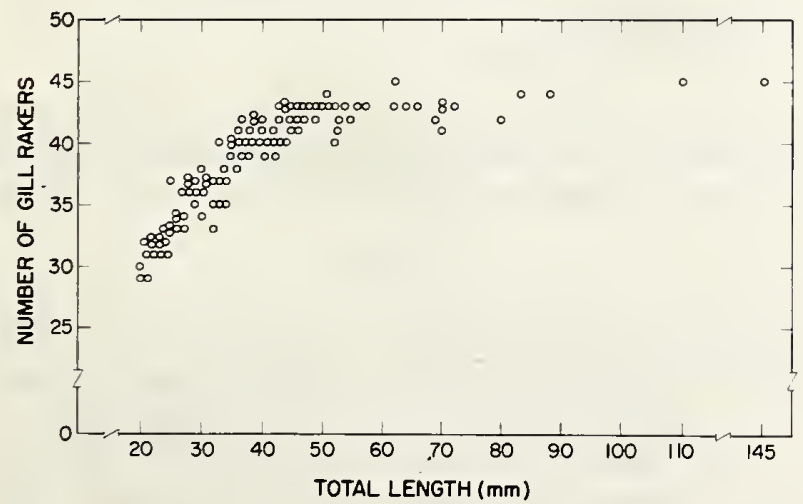

Figure 27.-Gil raker counts of young Auxis thazard plotted against total length (Klawe and Shimada 1959).
Noting that their specimens differed in sorne respects from observations made by Starks (1910) and Kishinouye (1923), Schaefer and Marr (1948) suggested that some of the specimens they examined may be juveniles of an undescribed species. Wade (1949), on the other hand, suggested that Schaefer and Marr examined juveniles of two species of Auxis. Schaefer and Marr's specimens, 42,48 , and $68 \mathrm{~mm} \mathrm{TL}$, had gill raker count3 of 39,41 , and 42 , respectively; these counts fall within the limits for A. thazard. Two other specimens-52 and $54 \mathrm{~mm}$-had gill raker counts of 48 and 47 , respectively, well within the limits of the gill raker counts for $A$. rochei.

Juveniles of $A$. thazard collected in Indian waters have also been misidentified as those of $A$. rochei. Originally, Jones (1961) examined 26 juvenile specimens collected from Vizhingam on the west coast of India and called them $A$. rochei (Table 16 ). In a later paper, Jones (1963) pointed out that on reexamining the material, specimens measuring $44.0-132.0 \mathrm{~mm}$ in length cannot be definitely assigned to $A$. rochei; rather, they could more correctly be assigned to $A$. thazard. He concluded that the remaining juveniles, from 181.0 to $209.8 \mathrm{~mm}$ were most likely $A$. rochei.

Juvenile Auxis are presumed to be relatively abundant in the world's oceans. One published report, based on the examination of juvenile tunas collected by midwater trawling in Hawaiian waters, indicated that the relative abundance of juvenile tunas is highest for skipjack tuna, reaching 7.0 juveniles/tow durirg the summer followed by yellowfin tuna, which was estimated at 2.2 individuals/tow (Higgins 1970). The catch rates were 1.6 individuals/tow for Auxis and below 1.0 individuals/tow for bigeye tuna, Thunnus obesus; albacore; and kawakawa, Euthynnus affinis.

\subsection{Adult phase}

\subsection{Hardiness}

The literature contains no direct evidence in reference to the hardiness of Auxis. Kishinouye (1923) observed that the salinity preference of scombroid fishes differs widely for different species. Auxis are sometimes seen in littoral waters of low density and apparently show no ill effect.

\subsection{Competitors}

Auxis compete against other tunas and tunalike fishes during all stages of their lives. Food studies indicate that most of the organisms consumed by Auxis also constitute part of the diet of other tuna and tunalike fishes; therefore, many species compete with them for food.

Species that have been mentioned specifically as possible competitors of Auxis in Japanese waters are given, by type of gear, in Table 17. In Hawaiian waters, Gosline and Brock (1960) observed that sometimes Auxis and kawakawa are caught in the pole-and-line fishery from mixed schools indicating that these two species are com- 
Table 16.-Measurements of Indian Ocean juvenile Auxis thazard (specimen Nos. 1-12, 14) and A. rochei (specimen Nos. 17, 19-26) in millimeters and the gill raker counts in the upper and lower limbs (Jones 1961).

\begin{tabular}{|c|c|c|c|c|c|c|c|c|c|c|c|}
\hline $\begin{array}{l}\text { Specimen } \\
\text { No. }\end{array}$ & Date & $\begin{array}{l}\text { Standard } \\
\text { length }\end{array}$ & Head & Snout & Eye & Maxilla & $\begin{array}{c}\text { Maximum } \\
\text { depth }\end{array}$ & $\begin{array}{c}\text { Snout } \\
\text { to } \\
\text { dorsal }\end{array}$ & $\begin{array}{c}\text { Snout } \\
\text { to } \\
\text { anal }\end{array}$ & $\begin{array}{l}\text { Longest } \\
\text { dorsal spine } \\
\text { length }\end{array}$ & $\begin{array}{c}\text { Gill } \\
\text { raker } \\
\text { count }\end{array}$ \\
\hline 1 & $?$ & 44.0 & 13.0 & 4.0 & 3.5 & 5.4 & 8.5 & 15.0 & 30.0 & 4.6 & - \\
\hline 2 & 29 May 1958 & 46.7 & 13.8 & 4.4 & 3.4 & 5.7 & 8.2 & 16.2 & 33.2 & 5.8 & $7+20$ \\
\hline 3 & 29 May 1958 & 46.8 & 14.0 & 4.1 & 3.2 & 5.5 & 8.6 & 16.3 & 33.9 & 5.0 & $7+20$ \\
\hline 4 & $?$ & 48.0 & 13.9 & 4.4 & 3.5 & 5.8 & 8.4 & 16.2 & 33.6 & 5.8 & $8+22$ \\
\hline 5 & 26 March 1959 & 49.2 & 15.1 & 4.4 & 3.3 & 6.1 & 8.9 & 17.3 & 35.7 & 5.2 & $8+21$ \\
\hline 6 & 26 March 1959 & 61.7 & 17.4 & 5.7 & 3.9 & 7.0 & 11.2 & 21.0 & 42.3 & 6.2 & $8+22$ \\
\hline 7 & 26 March 1959 & 67.0 & 19.2 & 6.2 & 4.0 & 8.0 & 12.0 & 23.0 & 46.2 & 7.5 & $8+23$ \\
\hline 8 & $?$ & 69.2 & 18.8 & 5.9 & 4.1 & 7.5 & 12.8 & 22.5 & 47.2 & 7.3 & $8+26$ \\
\hline 9 & 26 March 1959 & 79.5 & 22.0 & 6.3 & 4.5 & 8.1 & 14.7 & 26.1 & 55.0 & 8.0 & $9+31$ \\
\hline 10 & 30 Sept. 1958 & 125.0 & 33.0 & 9.8 & 6.1 & 12.0 & 22.0 & 38.5 & 85.0 & 12.6 & $9+31$ \\
\hline 11 & $?$ & 126.1 & 33.7 & 10.1 & 7.0 & 13.0 & 21.8 & 38.8 & 87.0 & 14.0 & - \\
\hline 12 & 30 Sept. 1958 & 128.5 & 33.8 & 10.2 & 6.3 & 12.8 & 23.0 & 41.0 & 89.2 & 13.7 & $10+31$ \\
\hline 14 & 30 Sept. 1958 & 132.0 & 35.0 & 10.4 & 6.4 & -12.9 & 23.3 & 41.0 & 89.4 & 14.8 & $10+30$ \\
\hline 17 & 30 Sept. 1958 & 181.0 & 48.0 & 13.5 & 9.0 & 15.7 & 34.0 & 55.3 & 131.1 & 16.5 & $10+36$ \\
\hline 19 & 30 Sept. 1958 & 183.0 & 49.0 & 11.8 & 11.0 & 16.5 & 36.0 & 51.2 & 128.0 & 20.0 & $11+35$ \\
\hline 20 & 30 Sept. 1958 & 185.3 & 46.7 & 11.9 & 9.0 & 15.3 & 33.8 & 57.0 & 131.5 & 16.8 & $11+35$ \\
\hline 21 & 30 Sept. 1958 & 187.5 & 49.0 & 12.0 & 10.0 & 16.5 & 36.9 & 59.5 & 131.9 & 19.9 & $10+34$ \\
\hline 22 & 3 Oct. 1958 & 189.0 & 49.0 & 12.4 & 9.0 & 15.5 & 36.9 & 59.7 & 134.0 & 18.7 & $11+34$ \\
\hline 23 & 3 Oct. 1958 & 191.0 & 50.1 & 12.8 & 9.2 & 16.0 & 36.2 & 59.5 & 134.5 & 19.5 & $10+35$ \\
\hline 24 & 3 Oct. 1958 & 196.0 & 51.5 & 13.2 & 10.2 & 17.2 & 36.0 & 62.5 & 142.0 & 19.2 & $10+36$ \\
\hline 25 & 3 Oct. 1958 & 205.2 & 51.5 & 12.5 & 9.2 & 16.0 & 38.0 & 61.0 & 139.5 & 20.2 & $11+34$ \\
\hline 26 & 3 Oct. 1958 & 209.8 & 55.8 & 14.0 & 10.5 & 17.2 & 41.0 & 65.6 & 150.2 & 22.2 & $10+36$ \\
\hline
\end{tabular}

Table 17.-Various fish species usually taken with frigate and bullet tunas and presumably in competition with them, by type of gear (Yokota et al. 1961).

\begin{tabular}{|c|c|c|c|c|}
\hline & $\begin{array}{l}\text { Pole } \\
\text { and } \\
\text { line }\end{array}$ & Troll & $\begin{array}{c}\text { Long } \\
\text { line }\end{array}$ & $\begin{array}{c}\text { Set or } \\
\text { fixed } \\
\text { net }\end{array}$ \\
\hline Albacore, Thunnus alalunga & $\mathbf{x}$ & & & \\
\hline Bigeye tuna, Thunnus obesus & $\mathbf{x}$ & $\mathbf{x}$ & & $\mathrm{x}$ \\
\hline Bluefin tuna, Thunnus thynnus & $\mathbf{x}$ & $\mathbf{x}$ & $\mathbf{x}$ & $\mathbf{x}$ \\
\hline Indo-Pacific bonito, Sarda orientalis & & $\mathrm{x}$ & & $\mathrm{x}$ \\
\hline Kawakawa, Euthynnus affinis & & $\mathbf{x}$ & & $\mathbf{x}$ \\
\hline Mahimahi, Coryphaena hippurus & & $\mathbf{x}$ & & \\
\hline Sailfish, Istiophorus orientalis & & $\mathbf{x}$ & $\mathbf{x}$ & \\
\hline Scad, Decapterus maruadsi & & & & $\mathrm{x}$ \\
\hline Skipjack tuna, Katsuwonus pelamis & $\mathrm{x}$ & $\mathrm{x}$ & $\mathbf{x}$ & $\mathrm{x}$ \\
\hline \multicolumn{5}{|l|}{ Japanese Spanish mackerel, } \\
\hline Spotted mackerel, Scomber australasicus & $\mathrm{x}$ & $\mathbf{x}$ & $\mathbf{x}$ & $\mathrm{x}$ \\
\hline Striped marlin, Makaira mitsukurii & & & $\mathrm{x}$ & \\
\hline Swordfish, Xiphias gladius & & $\mathbf{x}$ & $\mathbf{x}$ & \\
\hline Yellowfin tuna, Thunnus albacares & $\mathrm{x}$ & $\mathrm{x}$ & $\mathrm{x}$ & \\
\hline \multicolumn{5}{|l|}{ Yellowtail, Seriola aureovittata and } \\
\hline S. purpurascens & & & & $\mathbf{x}$ \\
\hline
\end{tabular}

peting for available food. Competitors of Auxis in African waters include yellowfin tuna, bluefin tuna, albacore, and bigeye tuna (de Jager et al. 1963). Other possible competitors mentioned by de Jager et al. are listed below.

Blue shark, Prionace glauca Mako shark, Isurus oxyrinchus Brown shark, Carcharhinus obscurus Thresher shark, Alopias vulpinus Moonfish, Lampris regius Angelfish, Brama raii Mackerel, Scomber japonicus Lancetfish, Alepisaurus ferox
Stockfish, Merluccius capensis

Snoek, Thyrsites atun

Yellowtail, Seriola lalandii

Skipjack tuna, Katsuwonus pelamis

Gannet, Morus capensis

Cormorant, Phalacrocorax capensis

Cape penguin, Spheniscus demersus

Wandering albatross, Diomedia exulans

Cape fur seal, Arctocephalus pusillus

Sperm whale, Physeter catodon

Sei whale, Balaenoptera borealis

In Indian waters, $A$. rochei and $A$. thazard, and other competitors such as Megalaspos cordyla, Stromateus niger, and $E$. affinis are frequently caught together in gill nets (Jones 1963). In the hook-and-line fishery, Jones observed that $A$. rochei, carangids, seerfishes, thunnids, and perches (includes lethrinids, lutjanids, and serranids) all appear in the catches.

\subsection{Predators}

Auxis, according to several studies, constitute a significant part of the food of adult tunas and billfishes. Predators listed by several investigators are as follows:

\section{Tunas}

Albacore, Thunnus alalunga (Kishinouye 1917, Japan; de Jager et al. 1963, South Africa; Dragovich 1968, Atlantic; Matthews et al. 1977, North Atlantic)

Bigeye tuna, T. obesus (Kishinouye 1917; King and Ikehara 1956, central Pacific; Yokota et al. 1961, Japan; de Jager et al. 1963; Watanabe 1964, Japan) 
Bluefin tuna, $T$. thynnus (Yokota et al. 1961; de Jager et al. 1963; Matthews et al. 1977)

Kawakawa, Euthynnus affinis (Ronquillo 1954; Philippine Islands)

Little tunny, E. alletteratus (Dragovich 1969)

Skipjack tuna, Katsuwonus pelamis (Kishinouye 1917, 1923, Japan; Ronquillo 1954; Yokota et al. 1961; Batts 1972, North Carolina)

Yellowfin tuna, T. albacares (Kishinouye 1917; Nakamura 1936, Celebes Sea; Mead 1951, eastern tropical Pacific; Ronquillo 1954; King and Ikehara 1956; Yokota et al. 1961; Alverson 1963, eastern tropical Pacific; de Jager et al. 1963; Watanabe 1964; Dragovich 1969; Matthews et al. 1977)

\section{Billfishes}

Black marlin, Makaira indica (Nakamura 1942, Taiwan; Watanabe 1964)

Atlantic blue marlin, $M$. nigricans (Krumholz and de Sylva 1958, Bahamas; Erdmian 1962, Puerto Rico)
Perhaps because of their abundance, Auxis are considered forage elements which occupy an important position in the food chain. In the eastern Pacific, $A$. thazard are of no commercial importance but they contribute to the tropical skipjack and yellowfin tuna fishery indirectly, because they constitute a significant part of the food of adult yellowfin tuna. In the western Pacific, Auxis, because of their distribution and abundance close to land masses, form a relatively high proportion of the forage of tunas and billfishes that are similarly distributed (Watanable 1964).

The size of Auxis consumed by large predators varies considerably. Klawe (1963) noted that specimens of $A$. thazard found in the stomachs of skipjack tuna, yellowfin tuna, and kawakawa varied from 60 to $125 \mathrm{~mm}$, but Watanabe (1964) has shown that Auxis up to $320 \mathrm{~mm}$ may fall prey to large tunas and billfishes (Table 18). In the Atlantic, Krumholz and de Sylva (1958) reported that Auxis ranging in size from 200 to $250 \mathrm{~mm}$ have been recovered from stomachs of blue marlin caught near Bimini in the Bahamas.

Table 18.-Size-frequency distribution of Auxis found in the stomachs of tunas and marlins (Watanabe 1964).

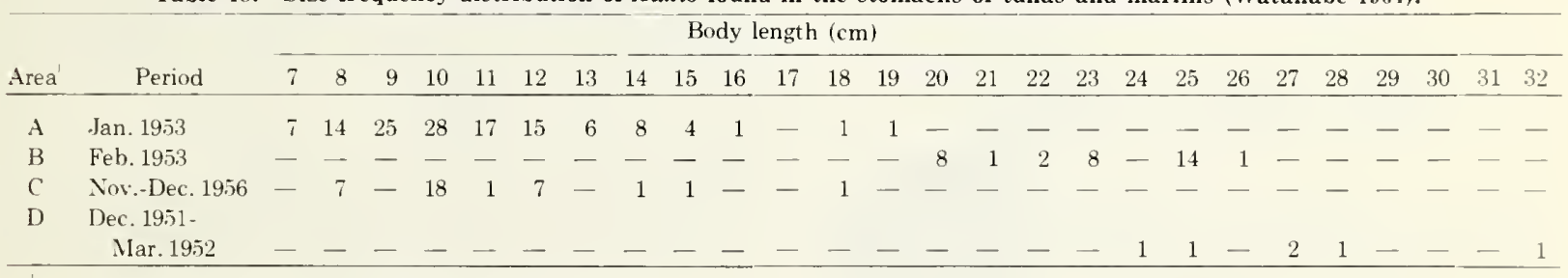

A - Banda Sea, north of Timor Island, Indonesia.

B - Sawu [Saru] Sea, south of Flores Island, Indonesia.

C - Off the coast of Queensland. Australia.

D - Off the southern coast of Shikoku, Japan.

Indo-Pacific sailfish, Istiophorus platypterus (Jones 1958, India; Idyll and de Sylva 1963, western Atlantic)

Striped marlin, Tetrapturus audax (Royce 1957, central Pacific)

White marlin, T. albidus (Idyll and de Sylva 1963; Davies and Bortone 1976, northeast Gulf of Mexico)

\section{Other Species}

Barracuda, Sphyraena sp. (Idyll and de Sylva 1963)

Lancetfish, Alepisaurus sp. (Matthews et al. 1977)

Mahimahi, Coryphaena hippurus (Ronquillo 1954; Idyll and de Sylva 1963; Rose and Hassler 1974, North Carolina)

Porpoise, Stenella sp. (Perrin et al. 1973, eastern tropical Pacific)

Thresher shark, Alopias yulpinus (Whitley 1964, Australia)

Tiger flathead, Neoplatycephalus richardsoni (Whitley 1964)

Wahoo, Acanthocybium solandri (Idyll and de Sylva 1963)
3.35 Parasites, diseases, injuries, and abnormalities

Table 19, extracted from MacCallum and MacCallum (1916), Linton (1940), Manter (1940, 1947, 1954), Vervoort (1965), Lewis (1967), Pillai (1967), Silas (1967a), Silas and Ummerkutty (1967), and Mamaev (1968), lists the monogenetic and digenetic trematodes, cestodes, and copepods that are parasitic on Auxis.

Table 19.-Monogenetic and digenetic trematodes, cestodes, and parasitic copepods on Auxis (MacCallum and MacCallum 1916; Linton 1940; Manter 1940, 1947, 1954; Vervoort 1965; Lewis 1967; Pillai 1967; Silas 1967a; Silas and Ummerkutty 1967; Mamaev 1968).
Type of parasite

Monogenetic trematode Digenetic trematode

Cestode

Parasitic copepod
Family

Hexostomatidae Bucephalidae Fellodistomidae Didymozoidae

Gorgoderidae Dasyrhynchidae

raligidae
Sproies

Hexostoma auxidi Rhipidocotyle capitatum Didymozoon auxis Ihacelotrema claciforme Opepherotrema planum Colocintotrema auxis Phyllodistomum lancea

Callitetrarhunchus gracilis Caligus macarovi C. productus C. auxisi

Bomolochidae
Tergestia laticollis 


\subsection{Nutrition and growth}

\subsection{Feeding}

Observations on the feeding habits of larval $A$. rochei indicate that they are particulate feeders. Yokota et al. (1961) observed that larval $A$. rochei between 3.0 and 5.4 $\mathrm{mm}$ in length consumed nauplii ranging in size from 0.10 to $10.30 \mathrm{~mm}$ and copepodites of about $0.55 \mathrm{~mm}$.

Auxis have been observed to use their caudal fin to hold their position in swift currents to capture drifting food and to migrate away from swift currents in search for food. They seek food not only by sight but also by using their lateral line sensory system (Imamura 1949; Uchihashi 1953).

The maximum size of fish eaten and also the total weight of food consumed by different sizes of $A$. rochei caught in the pole-and-line and set net fisheries have been discussed by Morita (1972). For the relationship between length of prey and body length of the predator, he calculated the following formula:

$$
Y=-0.015 X^{2}+0.358 X+9.075
$$

where $X=$ length of predator in centimeters

$Y=$ length of prey in centimeters.

The curvilinear relationship can be seen in Figure 28 .

The linear regression describing the relationship between weight of stomach contents and body length is shown in Figure 29. The equation is as follows:

$$
Y=2.33 X-40.78
$$

where $X=$ length of $A$. rochei

$Y=$ weight of the stomach contents in grams.

The selection of food organisms above a minimum size apparently is determined by the magnitude of gill raker gaps among mackerels, tunas, and dolphins. Magnuson and Heitz (1971), who calculated mean gill raker gaps of $0.74 \mathrm{~mm}$ for $A$. thazard and $0.51 \mathrm{~mm}$ for $A$. rochei, concluded that among scombrids Auxis and Katsuwonus have small gill raker gaps. The filtering areas of the two species of Auxis, which measured $570 \mathrm{~mm}^{2}$ for $A$. thazard and $55 \mathrm{~mm}^{2}$ for $A$. rochei, were intermediate when compared to other scombrids. Magnuson and Heitz suggested that gill raker gap and the maximum distensibility of the esophagus would set limits on the size of food eaten. Usually, however, selectivity in feeding among scombrids is masked because of the diversity of food organisms in the size range consumed by them.

Competition for food appears to be of fundamental importance in inducing young scombrids to feed (Clemens 1956). In the eastern Pacific, juvenile Auxis kept in shipboard aquaria learned to eat unnatural food that was offered them by watching other speciesmahimahi, Coryphaena sp.; jacks, Caranx sp.; pompano, Trachinotus sp.; threadfins, Polydactylus sp.; and pomacentrids, Chromis sp.-splashing and moving

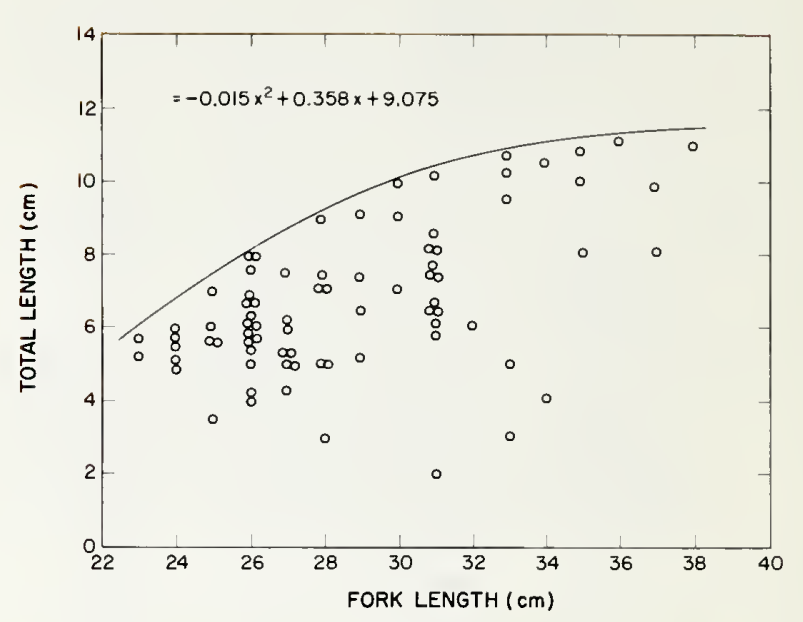

Figure 28.-Relationship between fork length of Auxis rochei and total length of prey consumed, off Japan (Morita 1972).

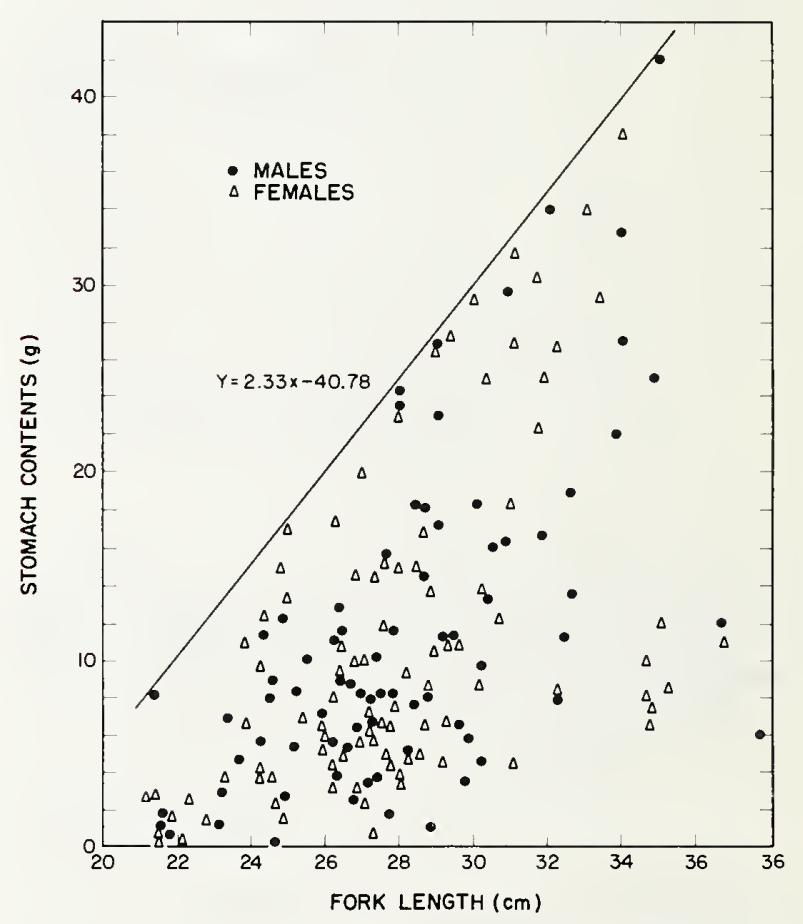

Figure 29.-Relationship between fork length of Auxis rochei and weight of stomach contents, off Japan (Morita 1972).

about the tank swiftly and striking voraciously at everything in sight (Clemens 1956). The food offered included live planktonic organisms, ground flesh of anchoveta, Cetengralis mysticetus, yellowfin tuna, skipjack tuna, and mahimahi, particles of coagulated fish blood, and mahimahi eggs.

\subsection{Food}

Planktonic crustaceans and fishes constitute a large part of the diet of juvenile Auxis. In Japanese waters, juvenile $A$. rochei, which were recovered from the 
stomachs of yellowfin and skipjack tunas, had larval copepods and decapods in their stomachs (Kishinouye 1924).

Auxis feed on a large variety of fishes, crustaceans, and molluscs. In Auxis captured in Hawaiian waters, fishes comprised the greatest volume with crustaceans next in rank (Tester and Nakamura 1957). Those captured in Japanese waters fed on plankton as well as a wide variety of herringlike fishes such as silverside, Atherina sp.; anchovy, Stolephorus sp.; small round herring, Spratelloides sp.; and immature Engraulis sp. (Kishinouye 1923). Okada (1955) observed that $A$. rochei fed on small pelagic organisms, anchovies, silversides, and other small fishes. Of $A$. rochei taken in Australian waters, Whitley (1964) found the stomach crammed with anchovies and young mullet.

Auxis also feed on their own young. Yokota et al. (1961) examined $A$. thazard caught by trolling in Japanese waters in June 1959 and discovered that their diet included young Auxis as well as skipjack tuna. Other items in their diet included jack mackerel, Trachurus japonicus; flyingfishes, Exocoetidae; filefishes, Monacanthidae; Mene maculata; round herring, Spratelloides japonicus; anchovy; and squids (Table 20).

Troll-caught $A$. rochei consumed anchovy as the principal food and other items only infrequently whereas those taken in set nets fed predominantly on jack mackerel with anchovy next in importance (Yokota et al, 1961). Spotted mackerel, Scomber australasicus, and

Table 20.-The number of identifiable orgamisms found in stomachs of 30 Auxis thazard caught by trolling gear in Japanese waters (Tokara fishing ground), June 1959 (Yokota et al. 1961).

\begin{tabular}{lc|lcrrr}
\hline \multicolumn{1}{c}{ Prey } & No. & \multicolumn{1}{c}{ Prey } & No. & Prey & No. \\
\hline Skipjack tuna & 9 & Flyingfishes & 1 & Kibinago & 8 \\
Frigate tuna & 1 & Filefishes & 1 & Squid & 6 \\
Jack mackerel & 2 & Ginkagami $^{2}$ & 1 & Anchovy & 147 \\
\hline
\end{tabular}

${ }^{1}$ Kibinago - Spratelloides japonicus (Houttuyn).

${ }^{2}$ Ginkagami - Mene maculata (Bloch). lizardfish, Saurida undosquamis, were also found in fair numbers in stomachs of fish caught by set net but were usually absent in stomachs of fish taken by trolling (Table 21).

In Indian waters, Thomas and Kumaran (1963) and Kumaran (1964), reporting on the stomach contents of 11 juvenile $A$. thazard $(49-132 \mathrm{~mm})$, observed that in small individuals $<75 \mathrm{~mm}$, fishes constituted $88 \%$ and crustaceans $12 \%$ by volume with squids entirely absent (Fig. 30). In individuals $>75 \mathrm{~mm}$, fishes formed $39 \%$ and Crustacea $42 \%$ by volume. Squids occurred very infrequently. Anchoviella sp. and Leiognathus sp. were the
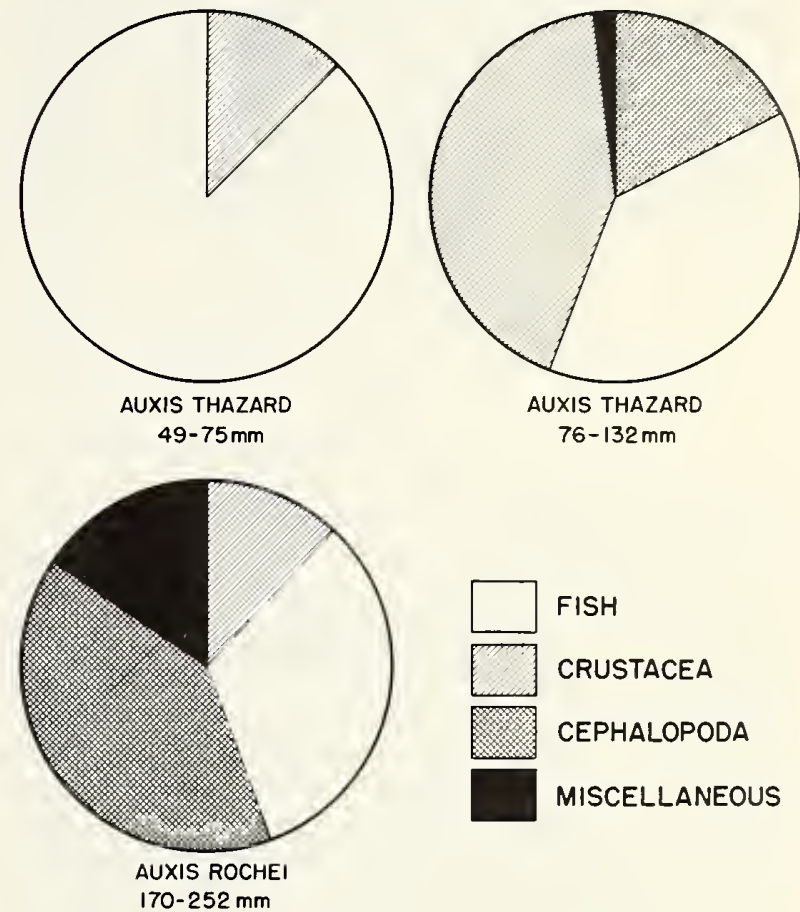

FISH

CRUSTACEA

CEPHALOPODA

MISCELLANEOUS

Figure 30.-Diagrams illustrating the composition, by volume, of the stomach contents of Auxis thazard and $A$. Rochei caught in the Indian Ocean (Thomas and Kumaran 1963).

Table 21.-The stomach contents of Auxis rochei caught by trolling gear and set net in Japanese waters. 1958-61 (Yokota et al. 1961).

\begin{tabular}{|c|c|c|c|c|c|c|c|c|c|c|c|c|c|c|}
\hline Date & $\begin{array}{l}\text { Fishing } \\
\text { ground }\end{array}$ & $\begin{array}{c}\text { Num- } \\
\text { ber }\end{array}$ & $\begin{array}{c}\text { Spotted } \\
\text { mackerel }\end{array}$ & $\begin{array}{c}\text { Jack } \\
\text { mackerel }\end{array}$ & Saury & $\begin{array}{l}\text { Nezumi } \\
\text { gisu }^{1}\end{array}$ & $\begin{array}{l}\text { Kurotachi } \\
\text { kamasu }^{2}\end{array}$ & $\begin{array}{l}\text { Sagi- } \\
\text { fue }^{3}\end{array}$ & $\begin{array}{c}\text { Lizard- } \\
\text { fish }\end{array}$ & $\begin{array}{c}\text { Hata- } \\
\text { aj1 }{ }^{4}\end{array}$ & $\begin{array}{l}\text { Matouishi- } \\
\text { mochi }^{5}\end{array}$ & $\begin{array}{c}\text { Mishima- } \\
\text { okoze }^{6}\end{array}$ & Squid & Anchory \\
\hline \multicolumn{15}{|l|}{ Trolling line: } \\
\hline Dec. 1958 & Kumanonada & 187 & & & & 2 & 2 & & & & 1 & & & 4 \\
\hline Feb. 1959 & Kumanonada & 175 & & & & & & & & 1 & & 2 & & 38 \\
\hline Mar. 1959 & Kumanonada & 105 & 4 & & 1 & & 2 & & 1 & & & & & 1 \\
\hline Dec. 1960 & Kumanonada & 30 & & & & & & & & & & & & 243 \\
\hline Apr. 1961 & Kumanonada & 17 & & 6 & & & & & & & & & 3 & 25 \\
\hline \multicolumn{15}{|c|}{ Set or fixed net: } \\
\hline Apr. 1961 & Tanegashima & 30 & 37 & 995 & & & & & 26 & & & & & 459 \\
\hline
\end{tabular}

${ }^{1}$ Nezumi gisu - Gonorhynchus abbreviatus Temminck and Schlegel.

${ }^{2}$ Kurotachi kamasu - Acinacea notha Bory and St. Vincent.

${ }^{3}$ Sagifue - Macrorhamphosus scolopax (Linné).

${ }^{4}$ Hataji - Elephenor macropus (Bellotti).

${ }^{5}$ Matouishimochi - Apogonichthys carinatus (Cuvier and Valenciennes).

${ }^{6}$ Mishimaokoze - Gnathagnus elongatus (Temminck and Schlegel). 
most common among the fish species consumed. Among 31 preadult $A$. rochei $(170-252 \mathrm{~mm})$, fishes constituted $42 \%$ by volume and were found in $80 \%$ of the samples (Fig. 31). Those that were important were Sardinella spp., Anchoviella sp., Leiognathus sp., and carangids (Table 22). Crustaceans were next in importance accounting for $24 \%$ by volume and found in $77 \%$ of the samples. Rabindra Nath (1962) reported that among the most common crustaceans consumed by Auxis in Indian waters were Rhopolophthalmus sp., Hyperia bengalensis, Oxycephalus clausi, Pseudophausia latifrons, Acetes erythreus, and Squilla larvae. Cephalopods formed $22 \%$ of the food consumed (Kumaran 1964), but pteropods were relatively unimportant in the diet (Rabindra Nath 1962). Kumaran (1964) also noted that larval stomatopods and Lucifer constituted a major portion of the diet of some specimens captured near Quilandy on the west coast of India. Other items of food occasionally seen were chaetognaths, Halobates, and polychaetes.

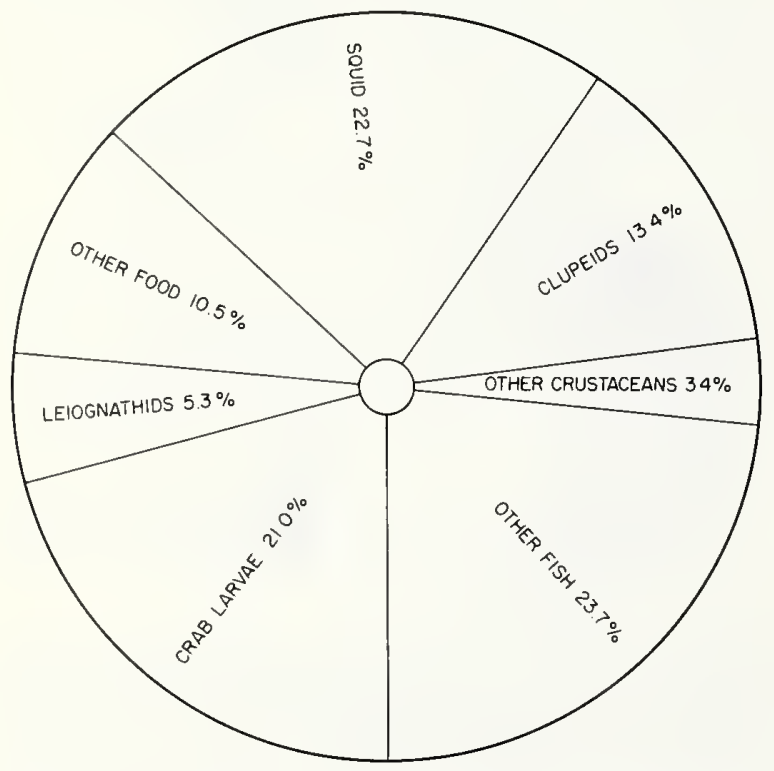

Figure 31.-Percentages, by volume, of the types of food consumed by preadult specimens of Auxis rochei in the Indian Ocean (Kumaran 1964).

\subsection{Growth rate}

Observations on postlarval growth indicate that captive Auxis grow faster than Euthynnus lineatus (Clemens 1956). Of five postlarval Auxis placed in an aquarium for observation, three died several hours later from injuries received in handling. Of the two remaining Auxis, one measuring $20 \mathrm{~mm}$ TL grew to $40 \mathrm{~mm}$ in 6 days; the larger $30 \mathrm{~mm}$ specimen reached $46 \mathrm{~mm}$ during the same period.

The rate of growth of $A$. rochei estimated from modal progression of length-frequency data appears to be rather slow compared to that observed in larvae that were hatched from artificially fertilized eggs. Hotta
Table 22.-List of food items of preadult specimens of Auxis rochei from the Indian Ocean (Kumaran 1964).

\begin{tabular}{lccc}
\hline \multicolumn{1}{c}{ Food items } & $\begin{array}{c}\text { Number of } \\
\text { food } \\
\text { organisms }\end{array}$ & $\begin{array}{c}\text { Percentage } \\
\text { of } \\
\text { prevalence }\end{array}$ & $\begin{array}{c}\text { Percentage } \\
\text { by volume }\end{array}$ \\
\hline Polychaeta & 14 & 3.2 & 1.2 \\
Crustacea: & $(142)$ & $(77.4)$ & $(24.4)$ \\
$\quad$ Amphipods & 8 & 16.1 & 0.9 \\
Mysis stage of prawn & 8 & 12.9 & 0.9 \\
Megalopa larvae & 118 & 38.7 & 21.0 \\
Alima larvae & 5 & 12.9 & 0.9 \\
Unidentified crustaceans & 3 & 6.4 & 0.6 \\
Insecta: & & & \\
Halobates & 2 & 3.2 & 0.6 \\
Chaetognatha: & & & \\
Sagitta spp. & 580 & 3.2 & 8.7 \\
Cephalopoda: & & & \\
$\quad$ Sepioteuthis sp. & 7 & 16.1 & 22.7 \\
Vertebrata (Pisces): & $(78)$ & $(80.6)$ & $(42.3)$ \\
Sardinella spp. & 5 & 9.7 & 3.5 \\
Clupeid larvae & 8 & 6.4 & 2.9 \\
Anchoviella commersonii & 3 & 6.4 & 2.3 \\
Anchoviella tri & 7 & 12.9 & 4.7 \\
Hemirhamphus sp. & 3 & 6.4 & 2.7 \\
Sphyraena sp. & 2 & 3.2 & 2.3 \\
Caranx sp. & 3 & 9.7 & 1.8 \\
Carangid larvae & 22 & 9.7 & 2.1 \\
Leiognathus sp. & 8 & 16.1 & 5.3 \\
Unidentified fish and larvae & 17 & 25.5 & 14.5 \\
\hline
\end{tabular}

(1955), who used monthly length-frequency histograms to estimate the growth of $A$. rochei caught in the northeastern sea off the Pacific coast of Japan, constructed a growth curve depicting body lengths at ages $0-I V$. From the curve, shown in Figure 32, it appears that $A$. rochei reach about $17 \mathrm{~cm} 1 \mathrm{yr}$ after hatching. But Harada, Murata, and Furutani (1973) observed that larvae of $A$. rochei under the best condition grew to $15.7 \mathrm{~cm}$ in 52 days (Fig. 21).

In addition to growth rates, the condition factor has been calculated for $A$. thazard. The condition factor $(\mathrm{K})$, which expresses the relative well-being of the fish,

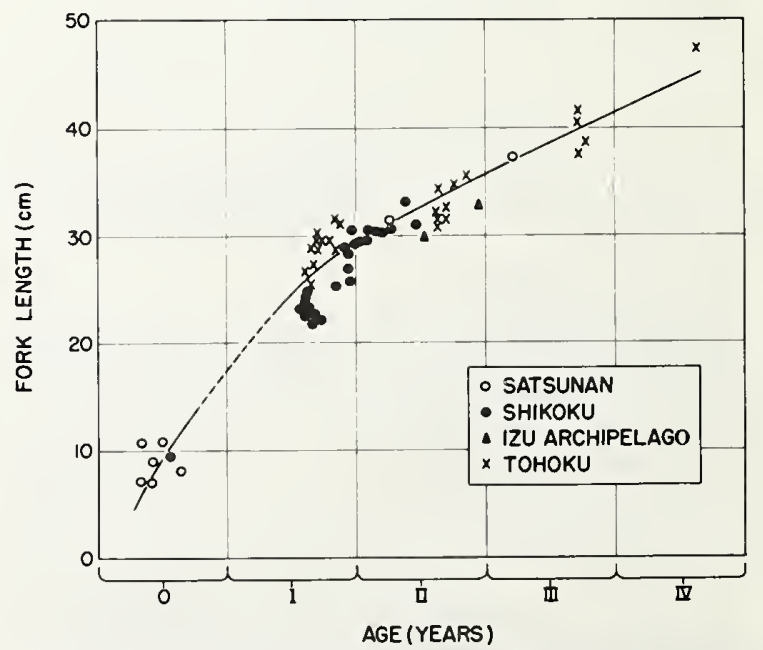

Figure 32.-Growth curve of Auxis rochei based on specimens from four localities in Japan (Hotta 1955). 
increases with age because older fish tend to gain proportionately more in weight than in length. The formula for $K$ is

$$
K=\frac{a W}{L^{3}}
$$

in which $a=$ constant

$W=$ weight in grams

$L=$ standard length in millimeters (Rounsefell and Everhart 1953).

At La Linea, Spain, the average values of the condition factor for each length group of $A$. rochei were usually larger for males than for females (Rodríguez-Roda 1966). Furthermore, the values of $K$ decreased from May to August, but increased in September which coincided with the spawning period. Comparison of $K$ among the size groups showed no significant differences.

Ishida (1971), who also calculated condition factor of Auxis caught off Japan, found that of the two species, $A$. thazard caught at Mikomoto and Shionomisaki had higher indices than $A$. rochei. Between areas, however, there appeared to be no appreciable difference.

The length-weight relationship has been described for $A$. thazard and $A$. rochei caught in the world's oceans. The expression for the relationship is

$$
W=a L^{b}
$$

in which $W=$ weight in grams

$$
\begin{aligned}
L & =\text { length in centimeters } \\
a \text { and } b & =\text { constants. }
\end{aligned}
$$

Table 23 gives the constant for the expression of the predictive length-weight relationship calculated by Ishida (1971) for both species of Auxis and by Yasui (1975) for A. rochei caught in Japanese waters, by Lenarz (1974) for $A$. rochei captured in the Atlantic Ocean, by Rodríguez-Roda (1966) for $A$. rochei caught in Spanish waters near the Strait of Gibraltar, and by Sivasubramaniam (1966) for both species caught around Sri Lanka in the Indian Ocean. Figure 33 depicts the length-weight curves constructed by Rodríguez-Roda (1966) and Yasui (1975). For A rochei caught in Spanish waters, Rodríguez-Roda has also provided the average and calculated weights for the length groups studied (Table 24).

The maximum size reported is $66 \mathrm{~cm}$ for $A$. rochei in the eastern Atlantic Ocean (Collignon see footnote 2).

Table 24.-Length groups, average weights, and calculated average weights of Auxis rochei caught at Barbate, Tarifa, and La Linea, Spain, in 1958, 1961, 1963, and 1974 combined (Rodriguez-Roda 1966).

\begin{tabular}{crcc}
$\begin{array}{c}\text { Size } \\
\text { intervals } \\
(\mathrm{cm})\end{array}$ & $N$ & $\begin{array}{c}\text { Average } \\
\text { weight } \\
(\mathrm{kg})\end{array}$ & $\begin{array}{c}\text { Calculated } \\
\text { average weight } \\
(\mathrm{kg})\end{array}$ \\
\hline $34-34.5$ & 2 & 0.635 & 0.654 \\
$35-35.5$ & 10 & 0.709 & 0.715 \\
$36-36.5$ & 26 & 0.782 & 0.780 \\
$37-37.5$ & 58 & 0.864 & 0.849 \\
$38-38.5$ & 97 & 0.947 & 0.922 \\
$39-39.5$ & 115 & 1.010 & 0.999 \\
$40-40.5$ & 117 & 1.089 & 1.080 \\
$41-41.5$ & 88 & 1.169 & 1.166 \\
$42-42.5$ & 89 & 1.250 & 1.256 \\
$43-43.5$ & 97 & 1.339 & 1.351 \\
$44-44.5$ & 34 & 1.428 & 1.450 \\
$45-45.5$ & 11 & 1.551 & 1.555 \\
Total & 744 & & \\
\hline
\end{tabular}

\subsection{Metabolism}

In $A$. rochei, a correlation has been found between sexual maturity and the amount of iron, copper, and zinc in various body tissues (Suzuki and Morio 1957). Suzuki and Morio showed that in the liver, the iron content decreases progressively with maturation, is at a minimum when the gonads become ripe and then increases significantly when the gonads are spent (Fig. $34 a$ ). The contents of copper and zinc show a similar tendency to decrease with maturation but minimums are reached at a stage when egg formation is still continuing in the ovaries (Fig. 34b, c). Suzuki and Morio also observed a negative correlation between the fat content of the liver and the amount of iron and copper (Fig. $34 \mathrm{~d})$. The relationship, however, is not consistent; it tends to break down in fish that have gonads approaching the ripe stage. Concerning molybdenum and nickel in the tissues of $A$. rochei, Morio and Suzuki (1959) determined that the former occurs in highest concentration in the liver whereas the latter shows up highest

\begin{tabular}{|c|c|c|c|c|c|c|c|}
\hline \multirow[b]{2}{*}{ Area } & \multirow[b]{2}{*}{ Investigators } & \multicolumn{3}{|c|}{ Auxis thazard } & \multicolumn{3}{|c|}{ Auxis rochei } \\
\hline & & $N$ & $a$ & $b$ & $N$ & $a$ & $b$ \\
\hline \multicolumn{8}{|l|}{ Japan: } \\
\hline & Yasui (1975) & - & - & - & $\mathrm{NA}^{1}$ & $1.549 \times 10^{-3}$ & 3.65705 \\
\hline Mikomoto & Ishida (1971) & $\mathrm{NA}^{\prime}$ & $6.05 \times 10^{-3}$ & 3.300 & $\mathrm{NA}^{1}$ & $4.13 \times 10^{-3}$ & 3.384 \\
\hline Shionomisaki & Ishida (1971) & $\mathrm{NA}^{\prime}$ & $7.70 \times 10^{-2}$ & 2.509 & $\mathrm{NA}^{\prime}$ & $4.64 \times 10^{-3}$ & 3.362 \\
\hline Atlantic & Lenarz (1974) & - & - & - & 50 & $2.80 \times 10^{-7}$ & 4.13514 \\
\hline Spain & Rodríguez-Roda (1966) & - & - & - & 744 & $1.00538 \times 10^{-5}$ & 3.129871 \\
\hline Sri Lanka & Sivasubramaniam (1966) & 160 & $1.780 \times 10^{-4}$ & 3.3338 & 28 & $2.598 \times 10^{-6}$ & 4.6315 \\
\hline
\end{tabular}
in the pyloric caeca. Further analysis indicated that the

Table 23.-Constants calculated by various investigators for the expression of the predictive length-weight relationship of Auxis thazard and A. rochei.

${ }^{1}$ Not available in the paper. 

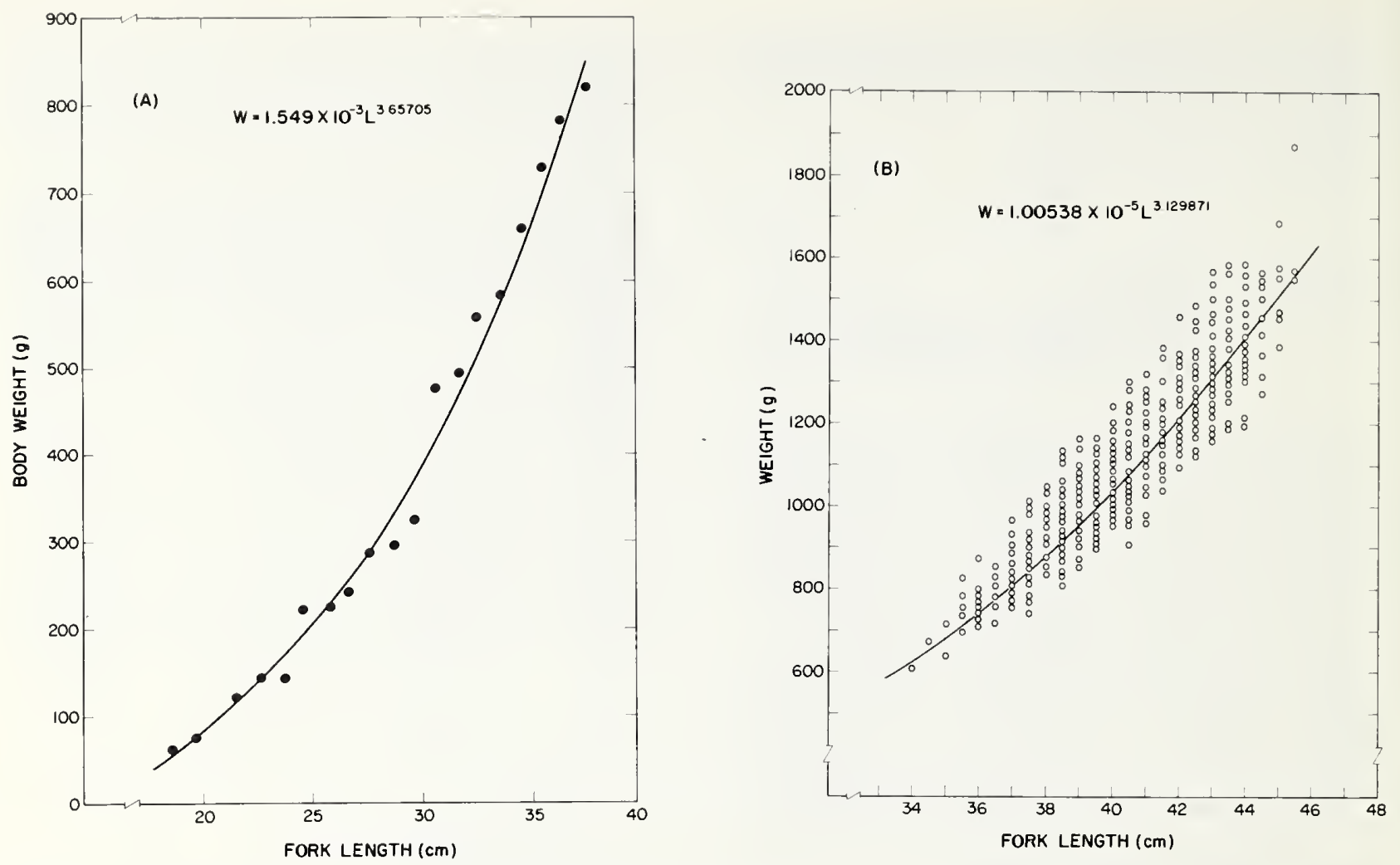

Figure 33.-Length-weight relationship of Auxis rochei caught in (A) Japanese waters (Yasui 1975) and in (B) Mediterranean waters (Rodríguez-Roda 1966).

contents of molybdenum and nickel in the liver show no relationship to sexual maturity, rate of growth, and area of catch.

The blood of Pacific $A$. rochei has been tested and found to be relatively high in hemoglobin concentration (Klawe et al. 1963). Barrett and Williams (1965) showed that compared with other scombrids, the mean level found for $A$. roche $i$ was among the highest, reaching 19.2 $\mathrm{g} / 100 \mathrm{ml}$ and varying from 16.5 to $22.8 \mathrm{~g} / 100 \mathrm{ml}$. Blood smears of $A$. thazard caught in Puerto Rican waters showed a blood count of 1 large hemoblast, 1 small hemoblast, 1 large lymphocyte, 30 small lymphocytes, 45 thrombocytes, and 22 granulocytes (neutrophils) (Saunders 1966). Mature erythrocytes from A. thazard blood averaged $10 \mu$ in length and $7.5 \mu$ in width.

\subsection{Behavior}

\subsection{Migrations and local movements}

Not much is known about the migration of Auxis in the world's oceans. Most of what is known comes from results of studies conducted in Japanese waters. Hotta (1955), after examining the fluctuations in landings of A. rochei along the coast of Japan in 1952, determined their seasonal movement up and down the coast of Japan. He observed that they occur in the Satsunan Sea region and off Shikoku early in the year, but as the year progresses, larger catches are made farther north and by
June they are landed in the Izu Archipelago region (Fig. 35 ). The schools reach their most northern point around Hokkaido in September, then move southward until in December they appear to be concentrated mostly off the Izu Archipelago and Shikoku.

Detailed studies of long-distance movement of $A$. rochei in Japanese waters showed that fish caught, tagged, and released in August, September, and November had a general tendency to move southward (Table 25, Fig. 36). Yamashige (1974) determined from his tagging studies that within the population of $A$. rochei off Japan, differential migration occurs according to size. The large influx of small fish into the fishery, as shown by the length-frequency distribution (Fig. 37), is the consequence of small fish moving south before the movement of large fish begins.

Short-distance movement of tagged $A$. rochei in Japanese waters shows that they tend to move southward late in the year although some northward movement is also seen, but early in the year there is a definite northward movement (Table 25) (Morita 1972; Hamada, Ishida, Morita, Takezawa, Okabayashi, and Ishii 1973; Hamada et al. 1974).

\subsection{Schooling}

The schooling instinct, according to a number of sources, is very strong and orderly in Auxis. Jones (1963) noted that the tendency of $A$. rochei to form large 
(a)

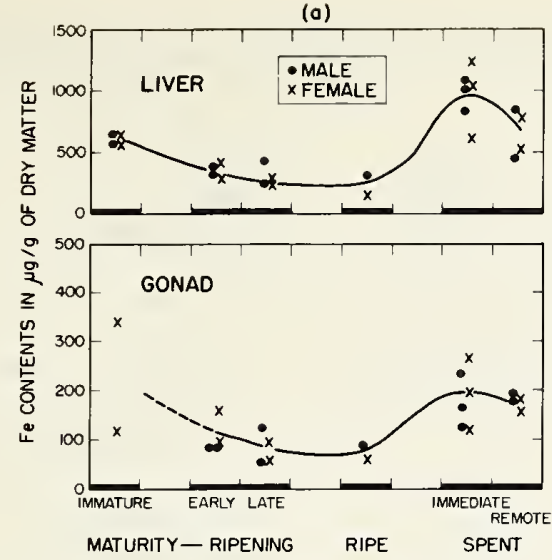

(c)

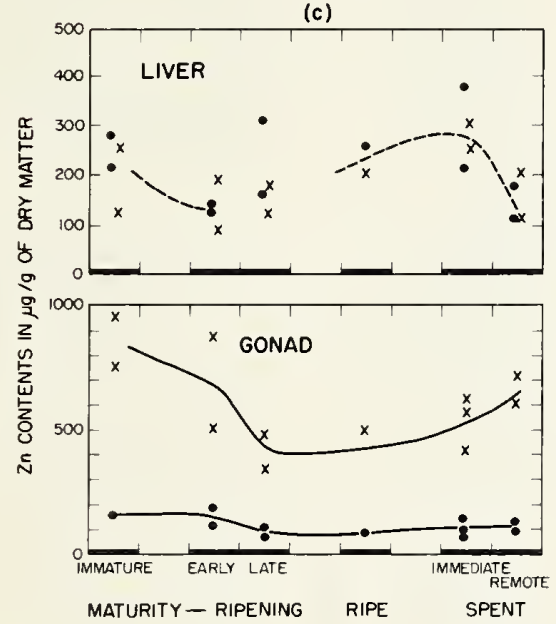

(b)

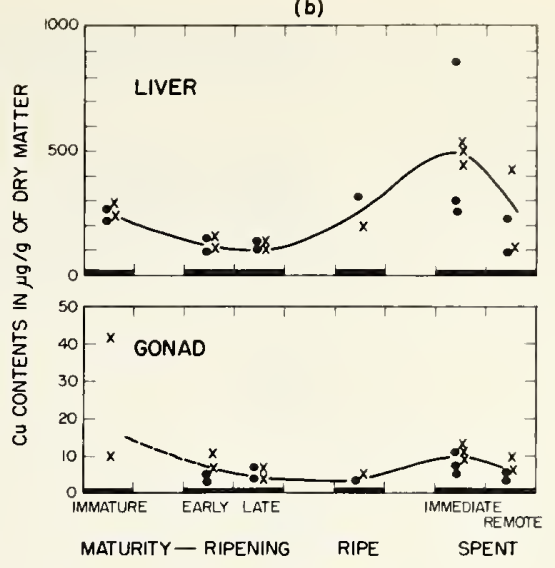

(d)

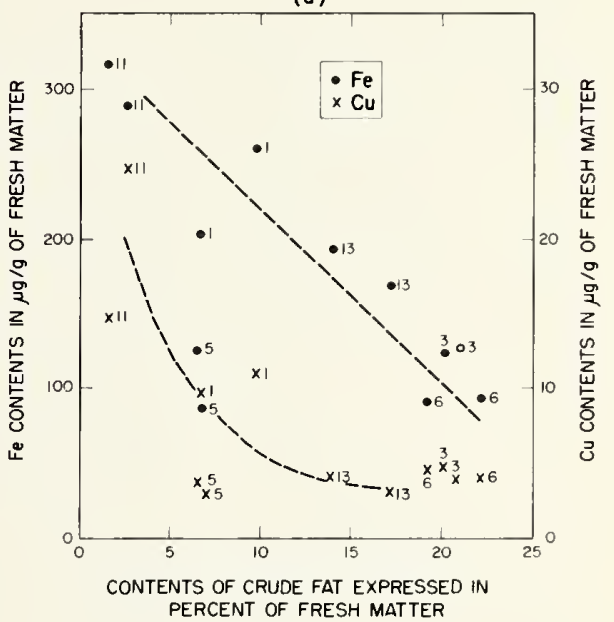

Figure 34.-Correlation between stage of maturation and contents of: (a) iron, (b) copper, (c) zinc in the liver and gonad, and (d) the relationship between the amounts of crude fat and of iron and copper in the liver, Auxis rochei (Suzuki and Morio 1947).

schools is strong not only among the adults but also among juveniles. Data collected during fishing operations suggest that individuals tend to school by size because those caught are more or less of the same length. The fish scatter when disturbed but soon school again. In Japanese waters, $A$. thazard, which usually school near the surface during morning and evening and also during periods of cloudy weather, do not form large schools (Imamura 1949). But the formation of dense schools appears to be quite common in other areas; for example, Nakamura (1938) reported that dense schools of Auxis migrate into coastal waters of Taiwan during certain times of the year and Serventy (1941) observed schools composed of hundreds of Auxis in southwestern Australia in the summer. In East African waters, Wheeler and Ommanney (1953) observed schools composed of 100 to 1,000 fish whereas Serventy described those around the Seychelles as "large" but gave no estimate of the numbers involved.

Schools of $A$. thazard are known to mix with those of $A$. rochei, other tunas, and tunalike fishes. In Hawaiian waters, Auxis are occasionally found mixed with schools of kawakawa (Gosline and Brock 1960), and both $A$. thazard and $A$ rochei have been reported captured from one school (Matsumoto 1960a). Similar observations were made by Kishinouye (1915) of Auxis in Japanese waters and by Jones (pers. commun. with Matsumoto in 1959) of those that occur in Indian waters. Imamura (1949) observed that $A$. thazard in Japanese waters are also found occasionally mixed with skipjack tuna.

There also appears to be some evidence that $A$. rochei schools distribute themselves throughout the water column by size. Morita (1972), who studied the movement of tagged $A$. rochei off Japan, indicated that small fish usually school near the surface and move faster than schools of large fish, which usually occupy the middle and deeper layers of the water column.

\subsection{Responses to stimuli}

The importance of light in relation to the diurnal activity of tunas has been discussed by Whitney (1969). Experimental work on the activity of various tunas in captivity showed that captive $A$. roche $i$ is negatively 
Table 25.-Partial data on release and recovery of Auxis rochei in the 1965 and 1970-72 fishing Hamada et al.

\begin{tabular}{|c|c|c|c|c|c|c|}
\hline $\begin{array}{l}\text { Date } \\
\text { of } \\
\text { release }\end{array}$ & $\begin{array}{l}\text { Area } \\
\text { of } \\
\text { release }\end{array}$ & $\begin{array}{l}\text { Location of } \\
\text { release }\end{array}$ & $\begin{array}{l}\text { Number } \\
\text { of fish } \\
\text { released }\end{array}$ & $\begin{array}{l}\text { Fork } \\
\text { length at } \\
\text { release } \\
(\mathrm{cm})\end{array}$ & $\begin{array}{c}\text { Tag } \\
\text { numbers }\end{array}$ & $\begin{array}{l}\text { Number } \\
\text { recap- } \\
\text { tured }\end{array}$ \\
\hline \multicolumn{7}{|l|}{1965} \\
\hline 26 Aug. & & $36^{\circ} 02^{\prime} \mathrm{N}, 141^{\circ} 02^{\prime} \mathrm{E}$ & & & & \\
\hline 15 Sept. & & $34^{\circ} 38^{\prime} \mathrm{N}, 138^{\circ} 58^{\prime} \mathrm{E}$ & & & & \\
\hline 22 Sept. & & $34^{\circ} 41^{\prime} \mathrm{N}, 139^{\circ} 27^{\prime} \mathrm{E}$ & & & & \\
\hline 25 Sept. & & $33^{\circ} 29^{\prime} \mathrm{N}, 135^{\circ} 58^{\prime} \mathrm{E}$ & & & & \\
\hline 7 Nov. & & $33^{\circ} 25^{\prime} \mathrm{N}, 135^{\circ} 49^{\prime} \mathrm{E}$ & & & & \\
\hline \multicolumn{7}{|l|}{1970} \\
\hline 5 Sept. & Tosa-wan & Off Yatabezaki & 299 & $19-21$ & & 1 \\
\hline \multirow[t]{2}{*}{ 13-15 Sept. } & - & Off Ito & 691 & $20-23$ & & 1 \\
\hline & & & & $28-29$ & & $\begin{array}{l}2 \\
3 \\
1 \\
2\end{array}$ \\
\hline 16-17 Sept. & & Off Shimada & 2,327 & $21-31$ & & 7 \\
\hline 19 Sept. & Kumanonada & Hamashima & 207 & 21 & & \\
\hline 20 Sept. & Kumanonada & Off Owase & 319 & 27 & & 1 \\
\hline $\begin{array}{l}29 \text { Sept. } \\
25 \text { Nov. }\end{array}$ & Tosa-wan & Off Susaki & 4 & 25.4 & & 2 \\
\hline & & & & & & 3 \\
\hline \multicolumn{7}{|l|}{1971} \\
\hline 21 Mar. & Ashizuri & $\begin{array}{l}\text { Ashizurimisaki SW, } \\
10 \mathrm{nmi}\end{array}$ & 60 & $23-28$ & & 1 \\
\hline 9 Nov. & Ashizuri & $\begin{array}{l}\text { Ashizurimisaki SSE, } \\
10 \mathrm{nmi}\end{array}$ & 307 & 24 & & $\begin{array}{l}1 \\
2\end{array}$ \\
\hline \multicolumn{7}{|l|}{1972} \\
\hline 26-27 Mar. & Satsunan & $\begin{array}{l}\text { Yukushima S, } \\
10-15 \mathrm{nmi}\end{array}$ & 409 & 25.8 & & 11 \\
\hline \multirow[t]{5}{*}{11 June } & Off Ashizuri & $\begin{array}{c}32^{\circ} 36.7^{\prime} \mathrm{N}, 132^{\circ} 54.9^{\prime} \mathrm{E} \\
\text { to }\end{array}$ & 89 & 29 & $1-100$ & 0 \\
\hline & & $32^{\circ} 36.7^{\prime} \mathrm{N}, 132^{\circ} 49.4^{\prime} \mathrm{E}$ & 99 & 29 & $101-200$ & \\
\hline & & & 100 & 29 & $201-300$ & \\
\hline & & & 100 & 29 & $401-500$ & \\
\hline & & & 16 & 29 & $801-820$ & \\
\hline \multirow[t]{2}{*}{31 Aug. } & Tosa-wan & Susaki, $0.5 \mathrm{nmi}$ & 400 & 21 & $1401-1800$ & 3 \\
\hline & & & 30 & 21 & 106-209 & \\
\hline 3 Sept. & & $34^{\circ} 59^{\prime} \mathrm{N}, 139^{\circ} 09^{\prime} \mathrm{E}$ & & & & \\
\hline 15 Sept. & $\begin{array}{l}\text { Satsunan off } \\
\text { southern } \\
\text { Kyushu }\end{array}$ & $\begin{array}{l}\text { Katamisaki, } \\
0.5 \mathrm{nmi}\end{array}$ & 5 & 23 & $1901-2000$ & 0 \\
\hline \multirow[t]{3}{*}{18 Sept. } & $\begin{array}{l}\text { Koshiki } \\
\text { Islands }\end{array}$ & Kami-Koshikishima & 53 & 24 & $1340-1360$ & 0 \\
\hline & & & & & $1600-1620$ & \\
\hline & & & & & $1901-2000$ & \\
\hline 19 Sept. & Satsunan & Bono-misaki & 2 & 24 & $1955-1956$ & 0 \\
\hline
\end{tabular}

phototactic (Inoue et al. 1970). Experiments on spectral sensitivity and color vision have determined that $A$. thazard is probably color blind (Tamura et al. 1972). Niwa et al. (1975) also determined that $A$. thazard, together with skipjack tuna, seem to have only one cone pigment with its maximum wave length at around 497 $\mathrm{nmi}$ in the classical position for rod sensitivity. They concluded that the position of the sensitivity maximum at such a short wave length undoubtedly is due to adaptation to oceanic behavioral life, because wave lengths which most effectively penetrate clear oceanic water varies between 480 and $500 \mathrm{nmi}$.

Nakamura and Magnuson (1965) observed opercular and orbital black spots on live $A$. thazard and $A$. rochei that were maintained in captivity in shoreside tanks.

They concluded that although the function of the opercular spots, if any, is not obvious, the orbital spot may reduce the amount of light reflected up into the eye from the ventral rim of the orbit. 
seasons off Japan (adapted from Morita 1972; Hamada, Ishida, Morita, Takezawa, Okabayashi, and Ishii 1973; 1974; Yamashige 1974).

\begin{tabular}{|c|c|c|c|c|c|c|c|}
\hline \multirow[b]{2}{*}{$\begin{array}{c}\text { Date of } \\
\text { recapture }\end{array}$} & \multirow[b]{2}{*}{ Location of recapture } & \multirow[b]{2}{*}{$\begin{array}{l}\text { Fishing } \\
\text { method }\end{array}$} & \multirow[b]{2}{*}{$\begin{array}{c}\text { Tag } \\
\text { number }\end{array}$} & \multicolumn{2}{|c|}{ Recapture } & \multicolumn{2}{|c|}{$\begin{array}{c}\text { Release } \\
\text { and recapture }\end{array}$} \\
\hline & & & & $\begin{array}{l}\text { Length } \\
\text { (cm) }\end{array}$ & $\begin{array}{c}\text { Weight } \\
(\mathrm{g})\end{array}$ & Days & $\begin{array}{c}\text { Distance } \\
(\mathrm{km})\end{array}$ \\
\hline \multicolumn{8}{|l|}{1965} \\
\hline 20 Sept. & $\begin{array}{l}\text { Uchiura-wan, Numazu, Shizuoka } \\
\text { Pref. }\end{array}$ & & & & & 25 & \\
\hline 18 Sept. & Katsuura, Chiba Pref. & & & & & 3 & \\
\hline 28 Nov. & Asagawa, $5 \mathrm{nmi}$, Tokushima Pref. & & & & & 67 & \\
\hline 17 Oct. & Off Susaki, Kochi Pref. & & & & & 22 & \\
\hline 3 Dec. & Ashizuri SW, $12 \mathrm{nmi}$ & & & & & 26 & \\
\hline \multicolumn{8}{|c|}{ 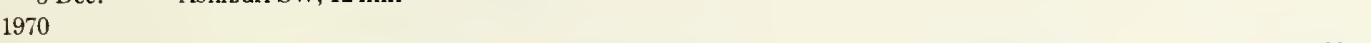 } \\
\hline 14 Sept. & Off Hiraiwa, Hyuga-shi & & & & 20.7 & 9 & 408 \\
\hline 15 Sept. & Uchiura-wan, Shizuoka Pref. & Purse seine & & & & 2 & 130 \\
\hline 26 Oct. & Ashizurimisaki NE, $1.5 \mathrm{nmi}$ & Pole and line & & & & i3 & 704 \\
\hline 9 Nov. & Ashizurimisaki SSW, $4.5 \mathrm{nmi}$ & Pole and line & & & & 26 & 704 \\
\hline $18 \mathrm{Sept}$. & Off Shimoda & Purse seine & & & & 2 & \\
\hline 23 Sept. & Off Tateyama, Chiba Pref. & Purse seine & & & & 7 & 93 \\
\hline 2 Oct. & Off Ose, Numazu-shi & Purse seine & & & & 16 & 83 \\
\hline 4 Oct. & Uchiura-wan, Shizuoka Pref. & Purse seine & & & & 18 & 93 \\
\hline $\begin{array}{l}\text { Not avail- } \\
\text { able }\end{array}$ & Off Shimoda-machi & & & & & & \\
\hline 2 Oct. & Off Mie Pref. & Purse seine & & & & 12 & 6 \\
\hline 26 Oct. & Off Shimoda, Shizuoka Pref. & & & & & 27 & \\
\hline 4 Dec. & Off Ashizurimisaki & Pole and line & & & & 9 & 89 \\
\hline $18 \mathrm{Dec}$. & Off Ashizurimisaki & Pole and line & & 25 & 160 & 23 & 89 \\
\hline \multicolumn{8}{|l|}{1971} \\
\hline 22 Mar. & Ashizurimisaki SSE, $6 \mathrm{nmi}$ & Pole and line & & & & 1 & \\
\hline 22 Nov. & Ashizurimisaki S, $18 \mathrm{nmi}$ & Pole and line & & & & 11 & \\
\hline 23 Nov. & Ashizurimisaki SSE, $8.5 \mathrm{nmi}$ & Pole and line & & & & 12 & \\
\hline 30 Nov. & Off Ashizurimisaki, $8 \mathrm{nmi}$ & Pole and line & & & & 21 & \\
\hline \multicolumn{8}{|l|}{1972} \\
\hline 10.11 Apr. & Off southern Yakushima & Pole and line & & & & 15 & \\
\hline
\end{tabular}

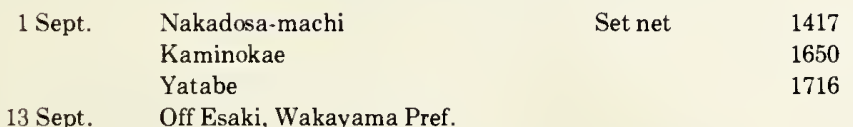

1417

1716

\section{POPULATION}

\subsection{Structure}

\subsection{Sex ratio}

The analysis of catches of $A$. rochei in April-December 1971 from waters off Kochi and Tohoku Prefectures, Japan, and off Taiwan indicates an inequality in sex ratio. Individual samples show significant deviation from a 1:1 ratio, e.g., the set net catches from Shiina, Japan, on 13 December had a ratio of two males to nine females. On the other extreme, the pole-and-line catch made off Taiwan on 19 June had a male to female ratio of 7:5 (Hamada, Morita, Ishida, and Takezawa 1973).

Off Sri Lanka, the number of males and females in the catches of $A$. thazard showed no noticeable difference from a 1:1 ratio except in one area (Sivasubramanium 1973). Along the southwest coast of the island, the 


\begin{tabular}{|cr|}
\hline KAN (8.27 POUNDS) & METRIC TONS \\
\hline$x \quad<1,000$ & $<3.75$ \\
$2-1,000-3,000$ & $3.75-11.25$ \\
$3-3,000-10,000$ & $11.25-37.51$ \\
$4-10,000-35,000$ & $37.51-131.29$ \\
$5 \_35,000-105,000$ & $131.29-393.88$ \\
$6,105,000-350,000$ & $393.88-1,312.94$ \\
7 & $>1,312.95$ \\
\hline
\end{tabular}
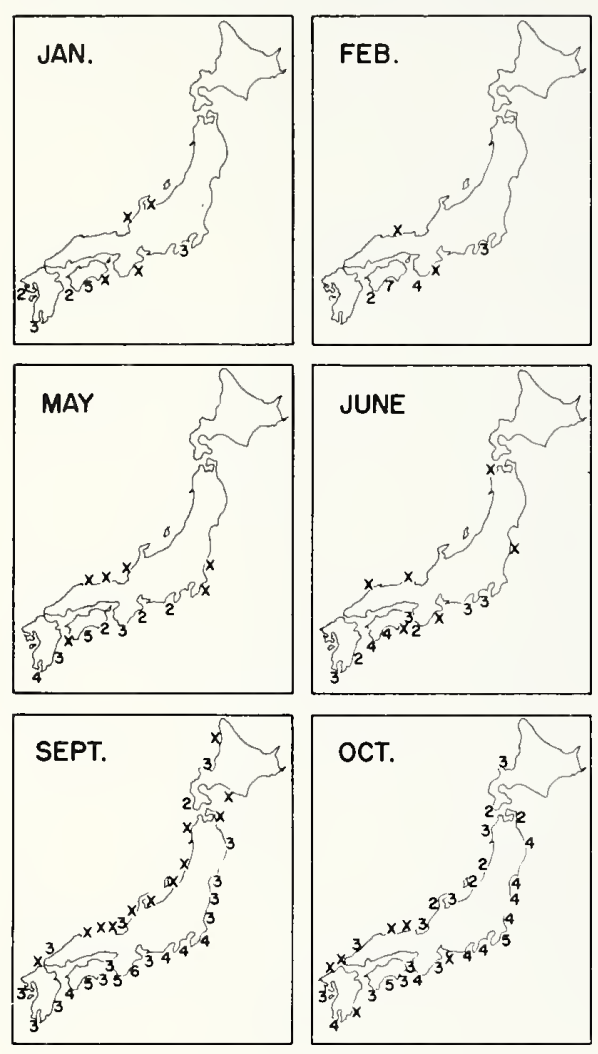

Figure 35.-Landings of Auxis rochei off Japan, by month, in 1952 (Hotta 1955).
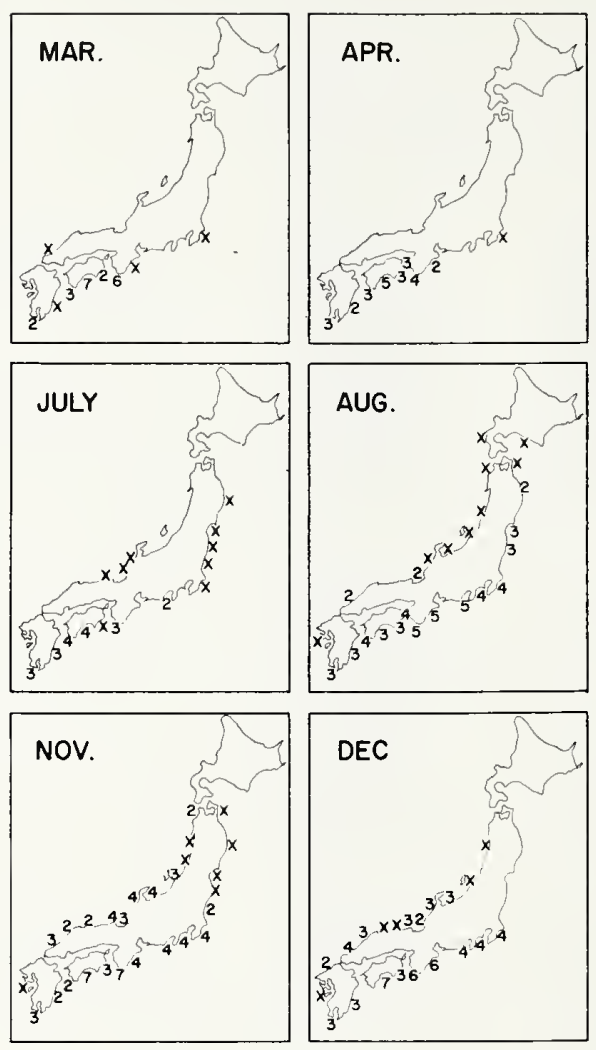

Figure 36.-Long distance movement of Auxis rochei tagged in August, September, and November (Yamashige 1974).

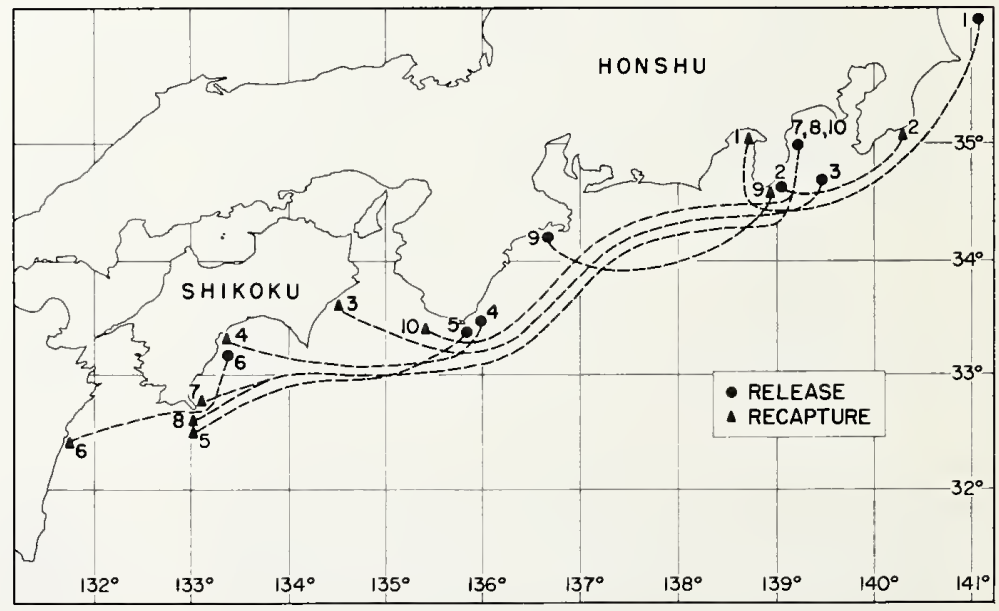

catches showed a slight predominance of females during periods of southwest monsoons; the male to female ratio reached 1:1.5 during this period.

For $A$. rochei caught in Spanish waters, RodriguezRoda (1966) also tested the ratios of males to females in the catches at Barbate, Tarifa, and La Linea, particularly for those months where a ratio of $1: 1$ was in doubt. The results showed no significant departures from a 1:1 ratio except at La Linea where in September 1961, significantly more males were taken in the traps. 


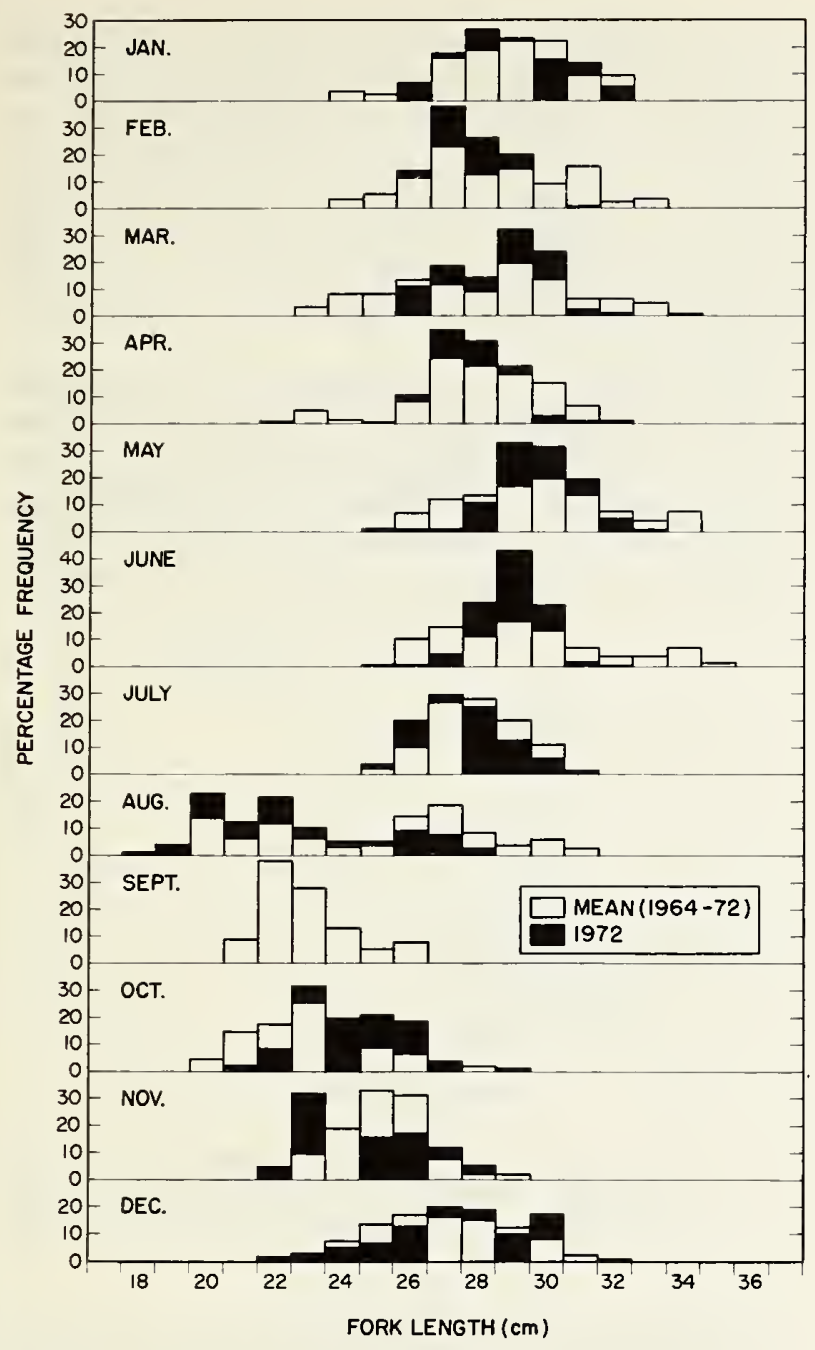

Figure 37.-Percentage length-frequency distributions, by month, of Auxis spp. taken in Japanese waters (Yamashige 1974).

\subsection{Size composition}

Although the size of $A$. rochei in the Japanese commercial catch varies widely from 4 to $50 \mathrm{~cm}$, the bulk of the catch usually falls between 20 and $35 \mathrm{~cm}$ (Fig. 38)

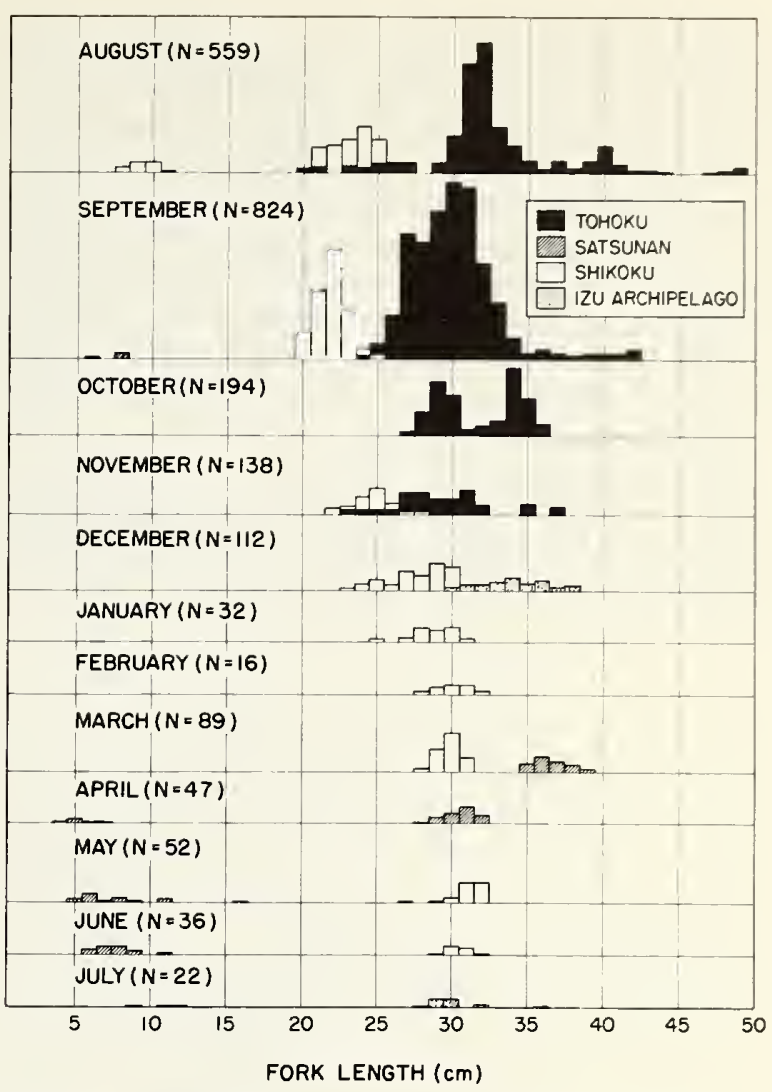

Figure 38.-Length-frequency distribution of Auxis rochei caught near Japan (Hotta 1955).

(Hotta 1955; Yokota et al. 1961). Furthermore, the average size of the fish varies considerably from month to month. Hotta (1955), Ishida (1972a), and Morita (1972) observed that the average size was usually smallest in August or September after which it increased gradually until early June of the following year then decreased sharply (Fig. 39).

In addition to the monthly variation in average size, there is also a large variation in the size range from month to month. Hamada, Morita, Ishida, and Takezawa (1973), who examined lengths of $A$. rochei caught in waters off Kochi Prefecture in Shikoku (north-
Figure 39.-Mean and range of fork lengths, by months, of Auxis rochei caught off Kochi Prefecture, Japan (Morita 1972).

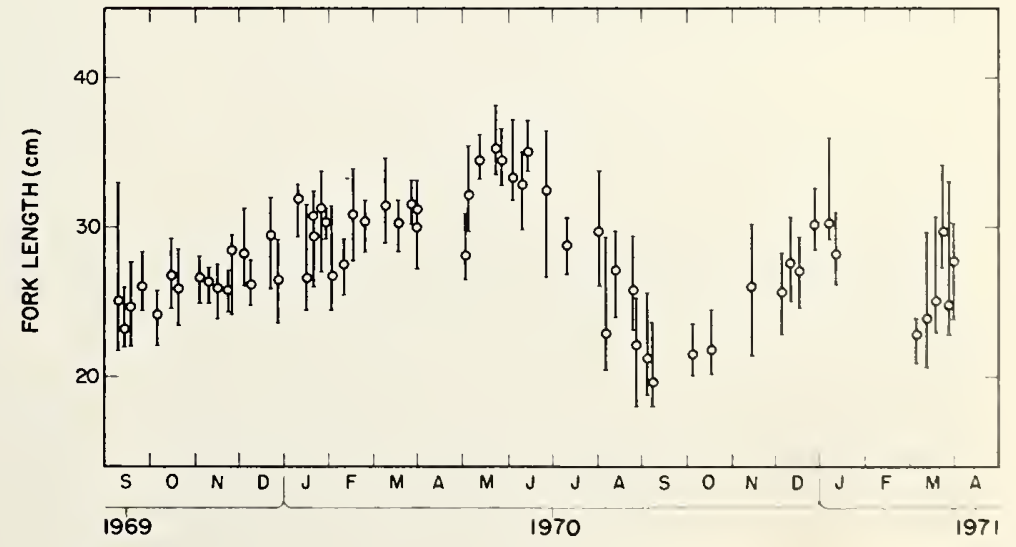


eastern), off Tohoku Prefecture, and off Taiwan, determined that the size range was usually narrowest among fish caught in October-November whereas it varied widely among the fish caught in May-June (Fig. 40).

Comparison of size data collected in Japan with those from the Philippines shows that the former's commercial catch constitutes smaller fish than the latter's. The size of Auxis taken by the purse seiners Royal Venture and Southward Ho in the Philippines, shown in Figure 41 , ranged from about 25 to $55 \mathrm{~cm}$ with the majority of the fish in the $40-45 \mathrm{~cm}$ range.

Data from the Indian Ocean show that the size of Auxis in the commercial catch also varies widely. Silas (1969) showed that $A$. thazard taken by drift net ranged from about 20 to $51 \mathrm{~cm}$, but a large proportion of the catch fell between 38 and $43 \mathrm{~cm}$ (Fig. 42). Silas also showed that compared with $A$. thazard, $A$. rochei are much smaller, ranging from about 19 to $29 \mathrm{~cm}$ and the mode at about 20 to $21 \mathrm{~cm}$. The purse seine apparently catches Auxis of more uniform sizes. Figure 43 shows that $A$. thazard caught by purse seine in Indian waters had a relatively wide range from about 32 to $46 \mathrm{~cm}$, but a large proportion of the fish fell between 40 and $42 \mathrm{~cm}$ (Silas 1969).

Off Sri Lanka, $A$. rochei appearing in the commercial catch are relatively small and their sizes vary from 16 to $34 \mathrm{~cm}$; however, most are between 22 and $30 \mathrm{~cm}$. Auxis thazard, on the other hand, are much larger and range from 20 to $58 \mathrm{~cm}$, but a large proportion of them falls between 22 and $40 \mathrm{~cm}$ (Sivasubramaniam 1968). Separat-

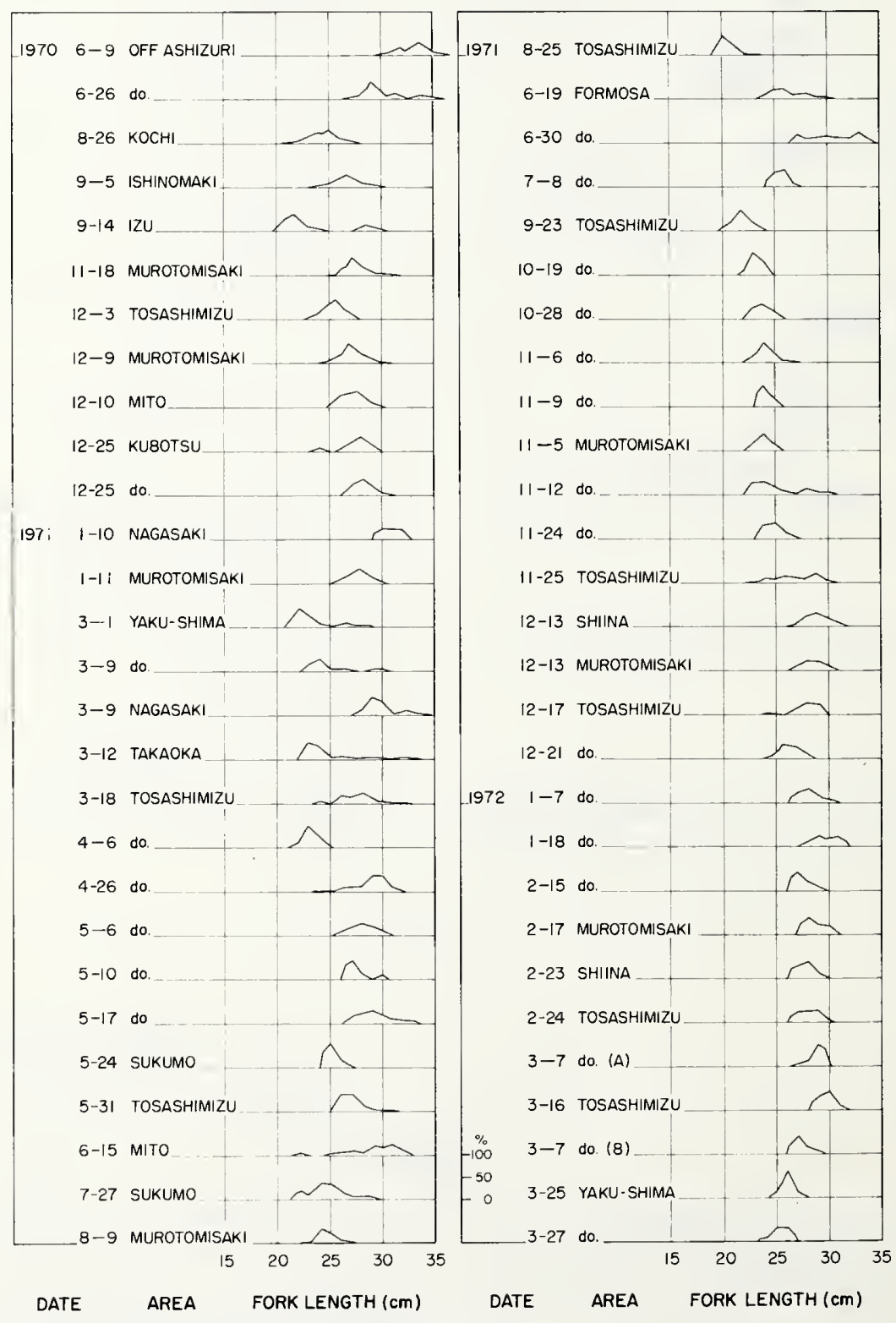

Figure 40.-Percentage frequency distribution of lengths of Auxis rochei, by date and area of capture, Japan (Hamada, Morita, Ishida, and Takezawa 1973). 

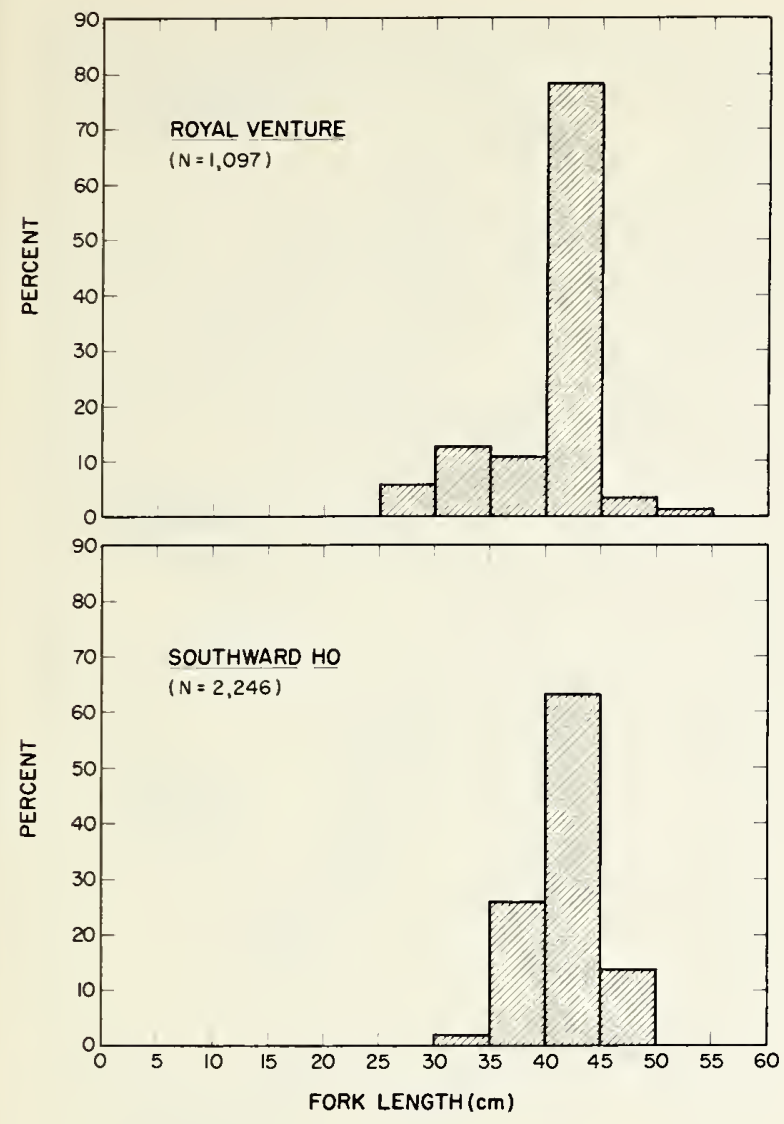

Figure 41.-Length-frequency distribution of Auxis sp. caught by the Royal Venture and Southward Ho, in Philippine waters, April-May 1975 (Rosenberg et al. see text footnote 9).

ing catches of $A$. thazard by type of gear, Sivasubramaniam also discovered that the size data from fish caught by beach seine were biased. Because large $A$. thazard present in the population were usually caught by other gear, the size of fish taken by the beach seines was not representative of the population of $A$. thazard in the area (Fig. 44). Most often, medium-sized fish, varying from about 28 to $44 \mathrm{~cm}$ were taken by this gear. The bulk of the catch, however, consisted of fish in the $32-36 \mathrm{~cm}$ length group.

Trolling gear is effective in taking small tunas such as Auxis as well as larger ones. Sivasubramaniam (1973) observed that although trolling gear samples a very wide size range of fish, it is particularly effective for $A$. rochei in the 28-32 cm length group, a group for which none of the other gears used has been effective. The smallest bullet tuna were usually taken in waters around Beruwala or further south (Sivasubramaniam 1965). Compared with size groups in the pole-and-line fishery, which captured mainly fish in the $44-46 \mathrm{~cm}$ and $48-50$ $\mathrm{cm}$ size groups, Sri Lanka's troll fishery exploited the smaller ones-26-28 cm, $32-34 \mathrm{~cm}$, and $36-38 \mathrm{~cm}$.

The sizes of Atlantic Auxis do not depart appreciably from those in the Pacific and Indian Oceans. Figures 45 and 46 show the percentage frequency distribution of lengths of $A$. rochei caught in various years at the Bar-

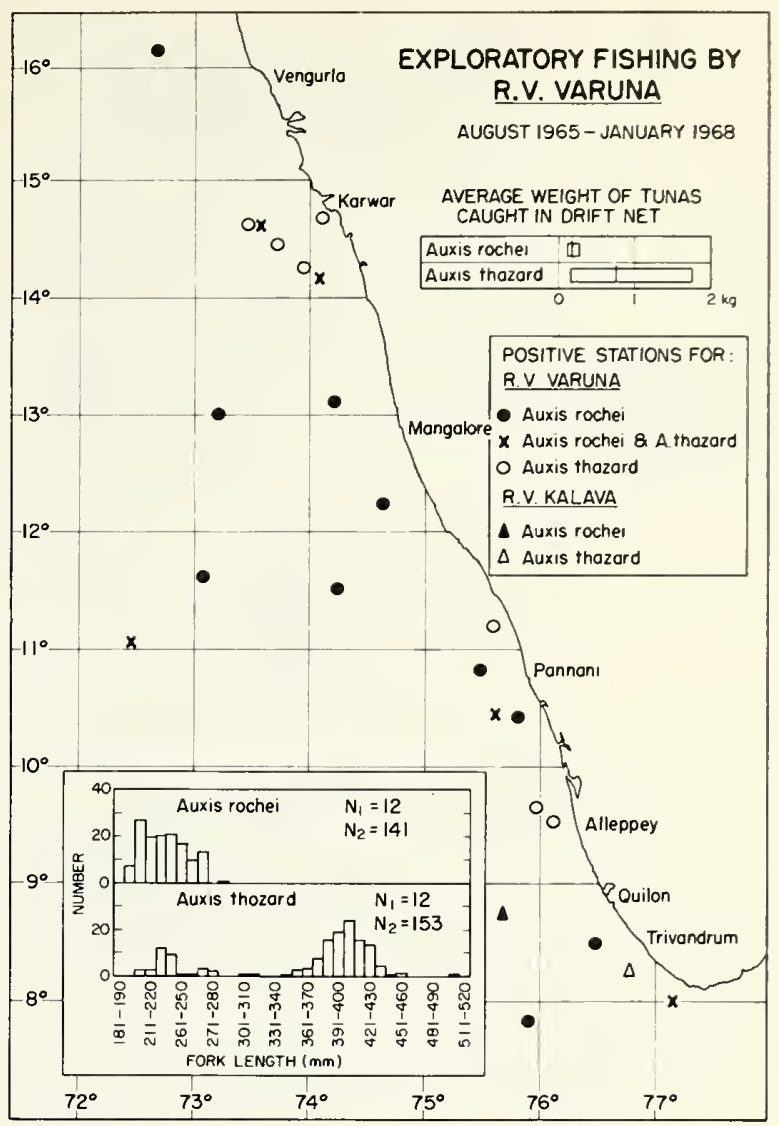

Figure 42.-Location of exploratory drift-net catches by the RV Varuna off southwestern India, and the length-frequency distribution and average weights of $A u x i s$ thazard and $A$. rochei in the catches (Silas 1969). $\left(N_{1}=\right.$ number of fishing operations; $N_{2}=$ number of specimens.)

bate, La Linea, and Tarifa trap net operations in Spain. Rodríguez-Roda (1966) reported finding two size groups in the Barbate and Tarifa samples-one around 38.5$39.5 \mathrm{~cm}$-and the other at about $45 \mathrm{~cm}$-and hypothesized that these two groups may possibly correspond to two age groups. Furthermore, he noted that at La Linea, the smaller group was at $40.5 \mathrm{~cm}$ and the larger at 42.5 $\mathrm{cm}$. This led him to suspect that two distinct populations of $A$. rochei may be involved in the catches at these localities. Rodrigues-Roda found no significant sexrelated differences in the length-frequency distributions.

\subsection{Abundance and density}

\subsection{Average abundance}

The relative abundance of Auxis in Japanese waters off Ashizurimisaki and Tosashimizu was discussed by Ishida (1972a). Using data collected in the Auxis poleand-line fishery from October 1964 to June 1967, Ishida found two peaks in the average number of vessels operating per day each month. The first peak occurred in March and the other in October, and during these months about 200 vessels/day participated in the fishery for Auxis. 


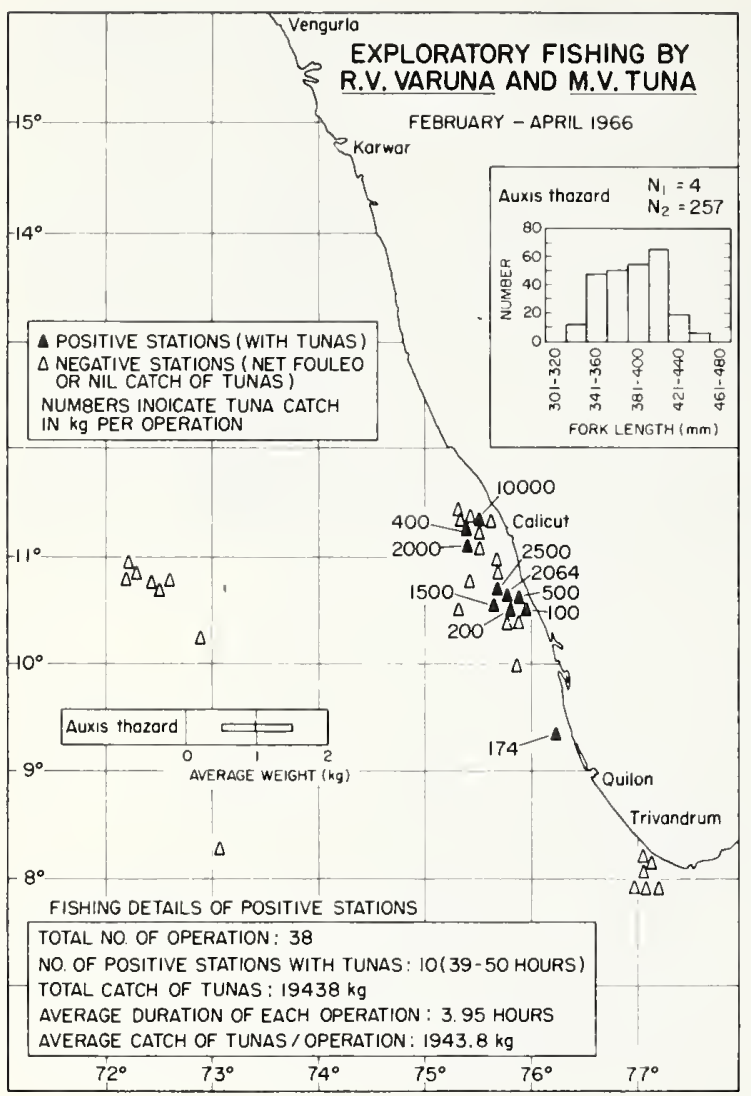

Figure 43.-Location of exploratory purse seine sets and catches for tunas by the RV Varuna and MV Tuna off southwestern India and the Laccadive Sea, and the length-frequency distribution and average weight of Auxis thazard in the catches (Silas 1969). ( $N_{1}=$ number of fishing operations; $N_{2}=$ number of specimens.

Figure 44.-The percentage frequencies of the number of Auxis thazard caught per operation, by type of gear, and of the fork lengths of the catches made off the southern and eastern coasts of Sri Lanka (Sivasubramaniam 1968).

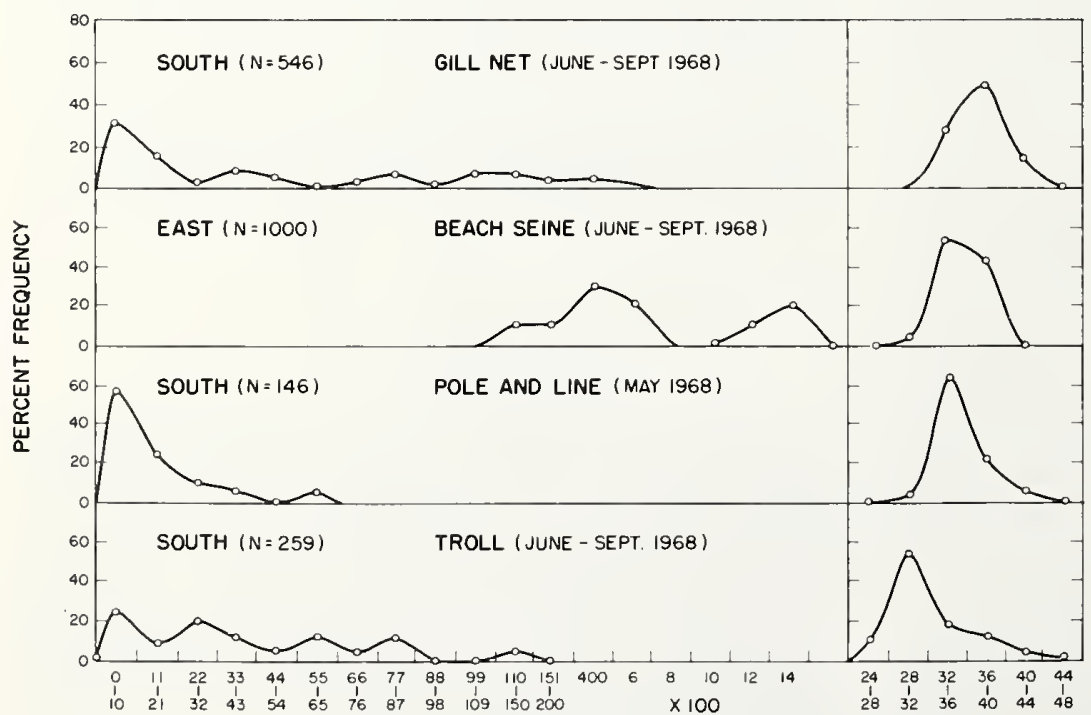

CATCH NUMBER PER OPERATION
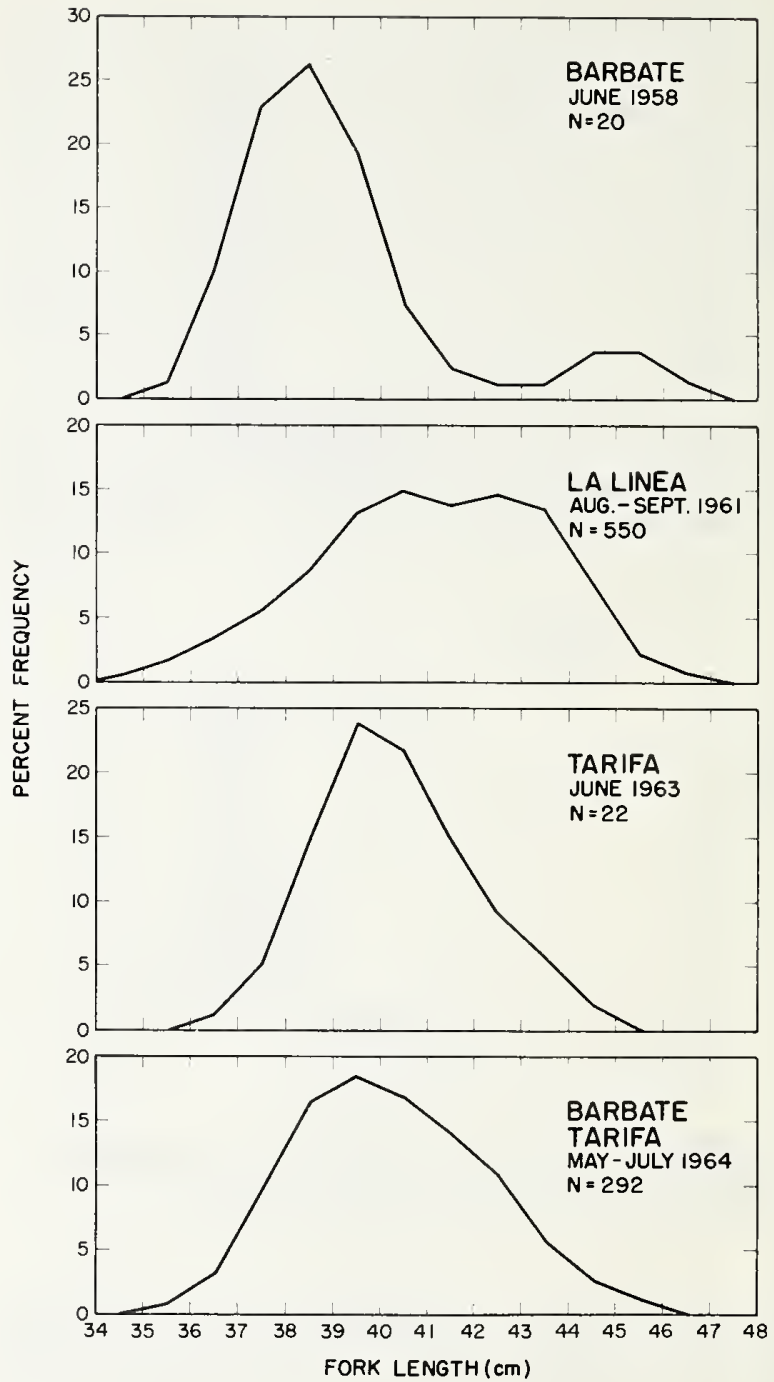

Figure 45-Length-frequency distributions of Auxis rochei caught by traps at Barbate, Tarifa, and La Linea, by month and year (1961, 1963, 1964) (Rodríguez-Roda 1966). 


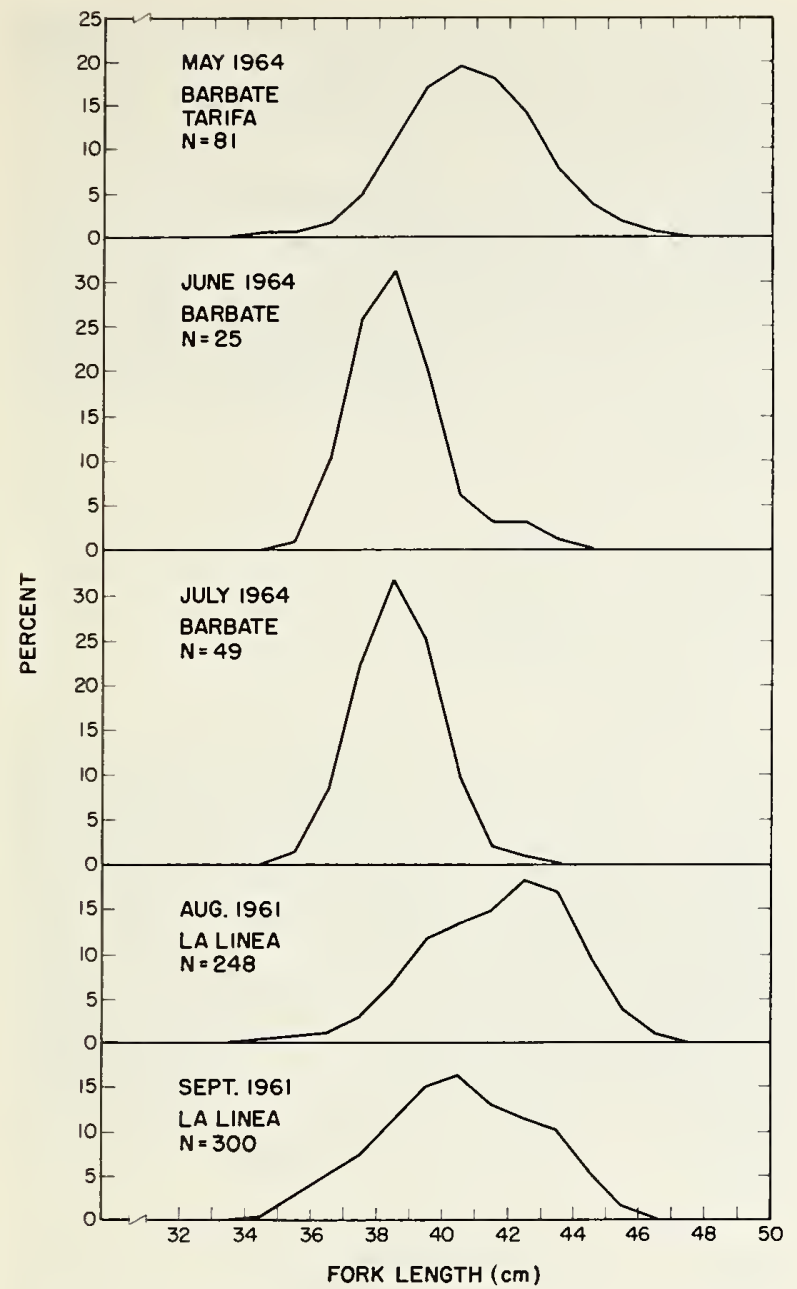

Figure 46.-Length-frequency distribution of Auxis rochei caught by traps at Barbate, Tarifa, and La Linea, by month and year (1961, 1964) (Rodríguez-Roda 1966).

Taking a vessel-day as a unit of fishing effort, Ishida (1972a) calculated the monthly landings per day and found that this index fluctuated in a similar fashion as the number of vessels in operation per day (Fig. 47). Ishida also constructed a frequency distribution of the landings per day and found that the primary mode fell at $30 \mathrm{t} /$ day ( $\mathrm{t}=$ metric tons) (Fig. 48). The annual mean was $52.4 \mathrm{t}$ /day but the seasonal mean, presumably calculated from selected data on landings per day for the peak months, reached $56.5 \mathrm{t} /$ day. A plot of landings per day on number of vessels operating per day showed that an increase in fishing intensity was usually accompanied by a similar increase in catch per day.

Off the coasts of Sri Lanka, Auxis are distributed in all waters surrounding the island but their densities vary widely (Sivasubramaniam 1973). Using the number of fish caught per standard trolling unit (a vessel with a fixed number of lines) per day, Sivasubramaniam found that $A$. thazard was most abundant along the southwest coast as catch rates reached 21.7 fish/boat-day. Almost equally high were the catch rates

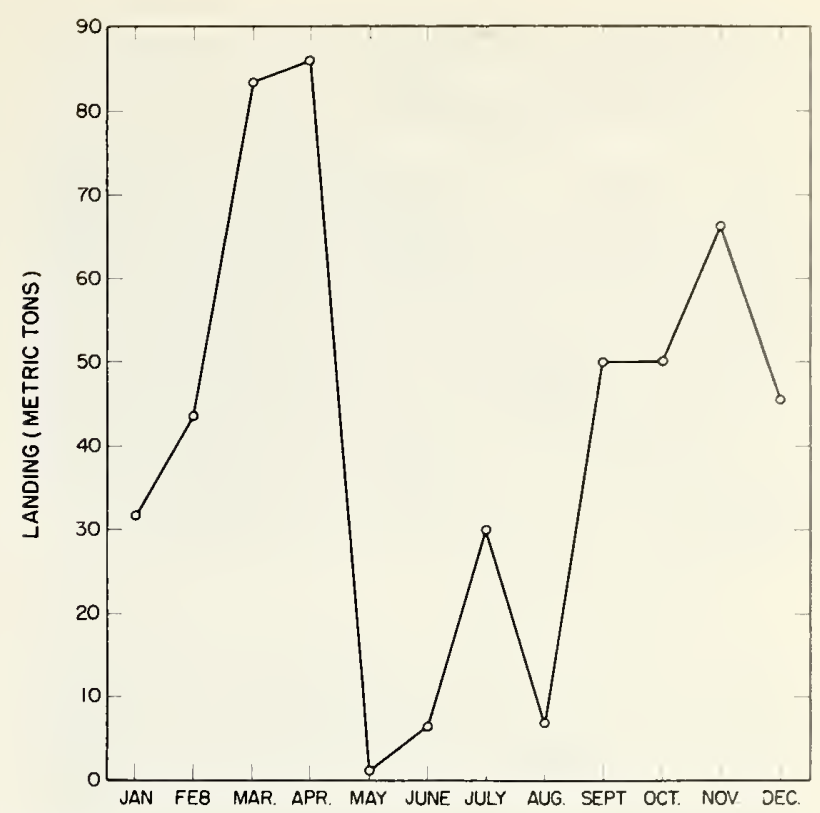

Figure 47.-Landings of Auxis spp. per day in the fishery off Ashizurimisaki, Japan, calculated from data collected from October 1964 to June 1967 and combined by months (Ishida 1972a).

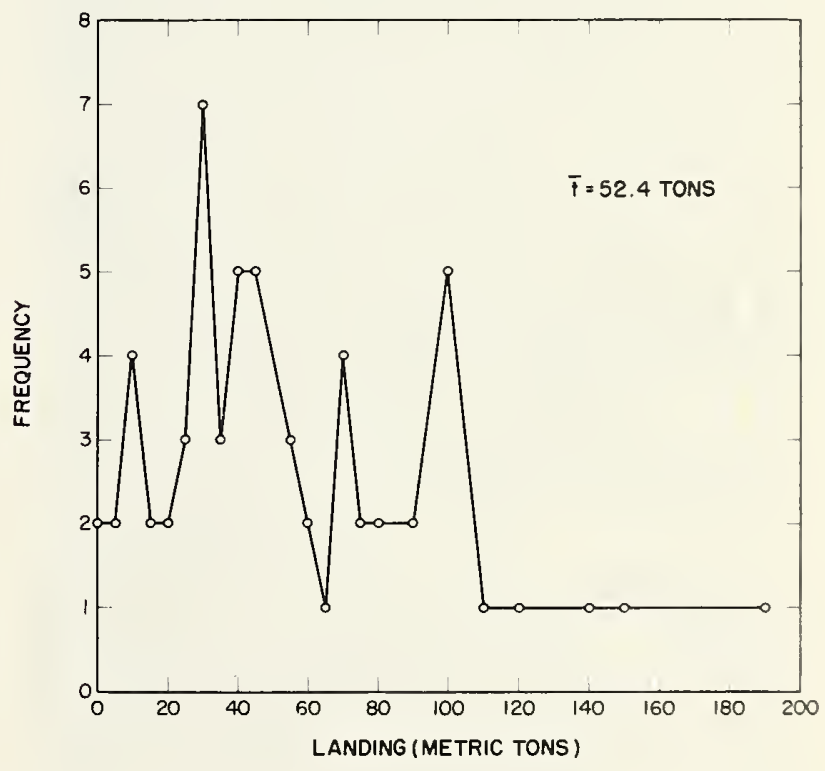

Figure 48.-Frequency distribution of landings per day in the fishery for Auxis spp. off Ashizurimisaki, Japan (Ishida 1972a).

along the southern coast which peaked at $21.3 \mathrm{fish} /$ boatday. Fish appeared to be fewer along the east and west coasts with catch rates of 18.9 and 14.3 fish/boat-day, respectively. The lowest catch rate occurred off the north coast with only 4.2 fish/boat-day. For $A$. rochei, the variation in catch rates followed a similar pattern. $\mathrm{Si}$ vasubramaniam (1973) estimated that usually a fishing vessel will encounter two to three mixed schools per day in waters around Sri Lanka. 


\subsection{Natality and recruitment}

\subsection{Reproduction rates}

An $A$. thazard of moderate size $(44.2 \mathrm{~cm})$ produces about 280,000 eggs/spawning and about 1.37 million eggs are extruded over the entire spawning season (Rao 1964). From Auxis caught in drift nets in Indian waters, Silas (1969) also estimated their fecundity and concluded that $A$. thazard $(n=9)$ spawn from 197,000 to 1,056 million eggs and average 601,000 eggs/spawning; for $A$. rochei $(n=4)$, he found fewer eggs per spawning. Silas estimated that females spawn from 31,000 to 103,000 eggs and average 52,000 eggs/spawning.

\subsection{Recruitment}

Off Sri Lanka, major recruitment to the exploitable stock of $A$. thazard occurs annually along the south and southwest coasts between March and August (Sivasubramaniam 1973). There is also evidence that sporadic recruitment occurs during the rest of the year. Off the east coast, recruitment has been observed in July-September, but no clear trend in recruitment has been found in catches along the north coast. For $A$. rochei, Sivasubramaniam conjectured that recruitment probably takes place at about the same time as that for $A$. thazard. Therefore, the exploitation of new recruits starts around the middle of the year then shifts to large size classes until the following year's recruitment.

The time of recruitment influences the annual production of Auxis in Sri Lanka (Sivasubramaniam 1973). When recruitment occurs during the southwest monsoon, the schools that enter the fishery are available at a time when the relative abundance of skipjack tuna, yellowfin tuna, and kawakawa is low and frigate and bullet tunas are fished until the beginning of the northeast monsoon. But when recruitment occurs late in the year, the fishing effort expended on these two species is less intense because of the presence of more desirable species such as skipjack and yellowfin tunas. Thus, fishing emphasis shifts from trolling to pole and line, longline, and drift netting. November-March marks the peak fishing season for the skipjack tuna pole-and-line fishery in the south and southwest coasts of Sri Lanka. It is at this time that large Auxis $(40-50 \mathrm{~cm})$, usually mixed with skipjack and yellowfin tunas, show up frequently in the catch.

\subsection{Mortality and morbidity}

\subsection{Factors causing or affecting mortalty}

An instance of natural mass mortality of larval Auxis in Hawaiian waters has been reported by Strasburg (1959). Noting the presence of two distinct conditions of larval Auxis in the preserved plankton samples collected in the vicinity of Lanai (an island in the Hawaiian chain), Strasburg hypothesized that these conditions represented fish that were alive and dead just prior to capture. In a simple experiment, he placed several fresh, dead specimens in dishes of seawater and allowed them to decompose. Other fresh, dead specimens were preserved in Formalin. The results showed that fresh preserved specimens were clean cut and normal in appearance whereas dead, deteriorated specimens were imperfect. Strasburg concluded that large numbers of larval Auxis in the samples were dead before capture, but no cause of death could be isolated. One possible cause of death is the passage of the larvae through an area of marked temperature discontinuity in the surface layer.

\section{EXPLOITATION}

\subsection{Fishing equipment}

\subsection{Gears}

Pole and line is the most commonly used gear to catch Auxis. In Japan, pole-and-line gear designed exclusively for fishing $A$. rochei differs from that used for skipjack tuna fishing. According to Yasui ${ }^{7}$ the pole-andline gear for bullet tuna consists of a bamboo pole, nylon monofilament, trolling board, and jig, and is attached at the butt end of a tag line to the vessel so that the entire gear is "trolled" at a speed of $2-3 \mathrm{nmi} / \mathrm{h}$ while searching for bullet tuna schools (Fig. 49). Two to three fishermen manage the "trolled" poles at the stern. When a fish

${ }^{7}$ M. Yasui, Shizuoka Prefectural Fisheries Experimental Station, Shizuoka, Japan, pers. commun. December 1975.
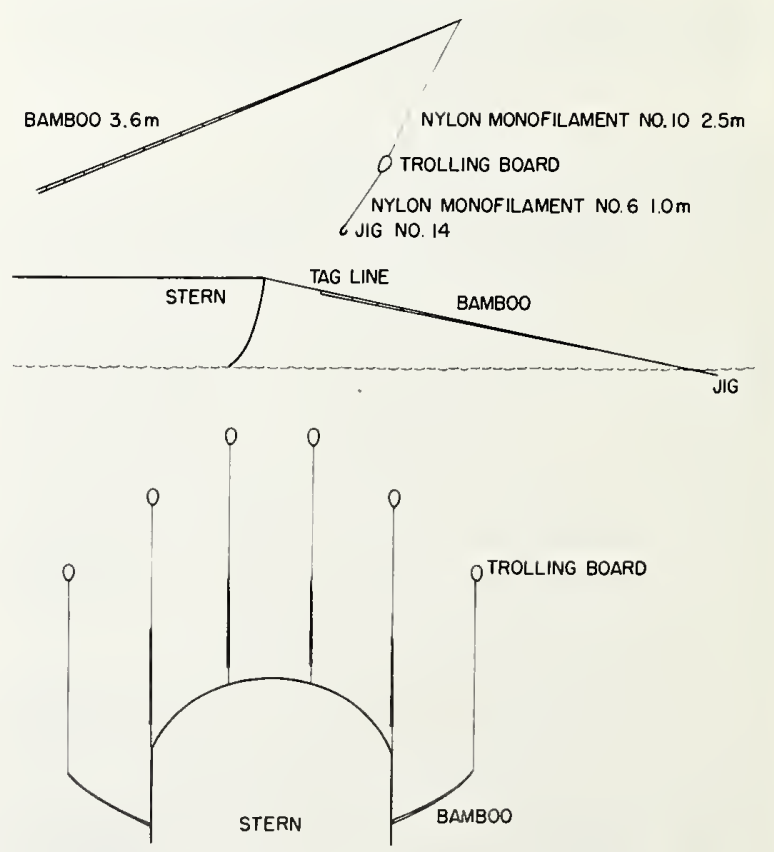

Figure 49.-Diagram of the pole-and-line gear used and the method of fishing in the fishery for Auxis spp. in Japanese water (Ishida 1971). 
strikes the lure, the fisherman pulls on the tag line, retrieves the pole, and flips the hooked fish aboard. A mixture of dead, salted "shirasu" (larval fish) and boiled noodles (somen) is chummed over the side while the boat circles the school counterclockwise, thus keeping the boat close to the dead shirasu and boiled noodles which are pushed toward the school by the rotation of the propeller. When biting is fast, the poles are no longer "trolled"; rather, each fisherman grasps one pole and flips the hooked fish aboard.

The use of other commercial gear depends on availability of Auxis and the efficiency of the gear. Among them are trolling line, handline, small-scale longline, and a wide assortment of nets including traps (set net, pound net), gill or drift nets, bag net, ring net, beach seine, otter trawl, and purse seine. In some countries where these gears are in use, Auxis are not the principal species sought by the fishermen; rather, they are caught when other species of tuna such as yellowfin, bluefin, and skipjack tunas either become unavailable or are relatively low in abundance. Some of these gears are discussed in the section that follows.

In the Philippines, purse seines appear to be effective in taking Auxis. To accelerate commercial development of pelagic fisheries, chartered commercial purse seiners, and research and survey boats under the South China Sea Fisheries Development and Coordinating Programme have been doing exploratory fishing including the detection and estimation of the abundance of the pelagic resources. Rosenberg and Simpson, ${ }^{8}$ reporting on voyage 3 of the purse seiners Royal Venture and Southward $\mathrm{Ho}$, stated that during the period when both worked the southeasterly portion of Moro Gulf, some of the floating logs seen had good signs of tuna. About 26,0$00 \mathrm{~kg}$ of "Tulingan" (probably Auxis) and kawakawa were landed, composing roughly $21 \%$ of the landings of the two seiners. Rosenberg and Simpson noted that large quantities of kawakawa and Auxis are consumed fresh in the Philippines, but there is no market for them when frozen.

The total landings of tuna by the two seiners after voyage 4 reached $31,000 \mathrm{~kg}$ of which Auxis represented about $11 \%$. Southward Ho usually caught less Auxis than the Royal Venture because the former used a slightly larger mesh in the bunt section of the seine (Rosenberg et al. ${ }^{9}$ ). The result was that $A$ uxis, which are smaller than either skipjack or yellowfin tunas, tended to gill and had to be discarded.

In Indian waters, $A$. rochei occasionally occur in very large schools close to shore and large quantities are usually taken by beach seines (Jones and Silas 1964).

\footnotetext{
${ }^{8}$ Rosenberg, K. J., and A. C. Simpson. 1975. Pelagic fisheries development-Trip reports, chartered purse seine vessels. (Trip reports of chartered purse seine vessels Royal Venture and Southward Ho, covering Voyage 3, 9 February to 26 March 1975.) South China Sea Fish. Dev. Coord. Programme, Manila, June 1975. SCS/75/WP/10, 28 p.

${ }^{9}$ Rosenberg, K. J., A. C. Simpson, and C. M. Renwick. 1975. Pelagic fisheries development-Trip reports, chartered purse seine vessels. (Trip reports of chartered purse seine vessels Royal Venture and Southward $\mathrm{Ho}$, covering Voyage 4, 9 April to 24 May 1975.) South China
} Dev. Coord. Programme, Manila, June 1975. SCS/75/WP12, 36 p.
Silas (1967b) reported that Auxis are very rare in the multiple troll catches made along the Tinnevelly coast in the Gulf of Mannar but are caught in small numbers together with skipjack tuna on pole-and-line and troll gear in the Laccadive Islands.

India, like the Philippines, has also been active in upgrading her tuna fishing capability. In January 1962, the Indo-Norwegian Project made the RV Varuna available to the Central Marine Fisheries Research Institute of India for exploratory fishing and oceanographic surveys in the Indian Ocean (Silas 1969). Two types of gear-drift net and purse seine-were used. Each unit of nylon drift net was $25.85 \mathrm{~m}$ long and $6.10 \mathrm{~m}$ wide. Five mesh sizes were used-2.5, 5.5, 10.0, 12.5 , and $17.0 \mathrm{~cm}$. The smaller mesh sizes captured juvenile pelagic fishes whereas the larger meshes captured $A$. thazard and $A$. rochei in both the continental shelf and oceanic areas. Figure 42 shows the number of drift net sets, the number of specimens collected, the average weight, and the length-frequency distribution of Auxis in the tuna catch.

Initial attempts at exploratory purse seining in the Laccadive Sea by the RV Varuna were unsuccessful, but subsequent attempts by the MV Tuna were reasonably successful (Silas 1969). The purse seine used in the exploratory work was $540 \mathrm{~m}$ long and $67 \mathrm{~m}$ wide with a mesh size of $10 \mathrm{~cm}$. Out of 38 purse seine sets, made with a net $540 \mathrm{~m}$ long, $67 \mathrm{~m}$ wide, and mesh size of $10 \mathrm{~cm}, 10$ were successful and the maximum catch exceeded $10 \mathrm{t}$ in one instance. The catch was composed mainly of schools of $E$. affinis and $A$. thazard. Figure 43 shows the locations of the purse seine sets, catch per set, and sizes caught. Silas noted that the average weight of $A$. roche $i$ was only $0.168 \mathrm{~kg}$ compared with an average of $0.750 \mathrm{~kg}$ for $A$. thazard. Of these early attempts at tuna purse seining in Indian waters, Silas remarked that they were not highly successful because the sinking rate of the net was too slow thus allowing the schools to escape. Also, he noted that the crew lacked experience in purse seining, but the failures, he felt, should not deter further attempts at purse seining.

In Sri Lanka, five types of gear are used to exploit tuna-longline, pole and line, trolling line, drift net, and beach seine. The longline is used for large, deepswimming tunas and will not be discussed here. The remaining four are used in varying degrees to catch Auxis.

The beach seine is not a selective gear for Auxis; therefore, the catch by this gear is insignificant (Sivasubramaniam 1965, 1973). Beach seining, requiring about 30 men to conduct successfully, is possible in places like Tangalle, Udapu, and Trincomalee, because schools of Auxis occasionally migrate close (within 0.9 $\mathrm{km}$ ) to shore.

The most important method of capturing Auxis off Sri Lanka, however, is by trolling. The gear is adapted from salmon trolling gear and is unlike the standard tuna trolling gear used extensively by Japanese and United States fishermen (Sivasubramaniam 1965). Consisting of three mainlines each with 30 branch lines which end in jigs, the trolling gear is well suited for Sri Lanka's waters because of the denseness of the schools of Auxis 
and kawakawa (Sivasubramaniam 1973). Trolling, usually limited to $3-5 \mathrm{~h}$ in the morning when Auxis schools are at the surface, is effective during periods of monsoon when the water is turbid. The gear was formerly operated from "orus" (outrigger canoes with sail), but catches were poor because of difficulty in maneuvering the vessel. Nowadays, 3.5-gross ton motorized boats, manned by crews of at least three fishermen, are used and their efficiency have made them popular for fishing the various species of tunas. Trolling contributes over $50 \%$ of the total Auxis production.

Pole-and-line fishing boats in Sri Lanka concentrate primarily on skipjack tuna but also catch significant quantities of other tunas including kawakawa, yellowfin tuna, and Auxis (Fig. 50). Sivasubramaniam (1965) pointed out that Sri Lanka's pole-and-line boats operate gear similar to that used by fishermen of Minicoy, Laccadive, and Maldive Islands. The boats, manned by at least five fishermen, carry live bait in cane baskets that are partially submerged alongside the craft. Wooden spades are used for spraying water. Originally, pole-and-line fishing was restricted to waters off the southwest coast of the island, but mechanization of the boats has expanded this type of fishing to the east coast. Like other pole-and-line fisheries operating in the Indian Ocean, however, the availability of live bait has limited the popularity of this fishing method.

Although pole-and-line fishing is effective for skip-

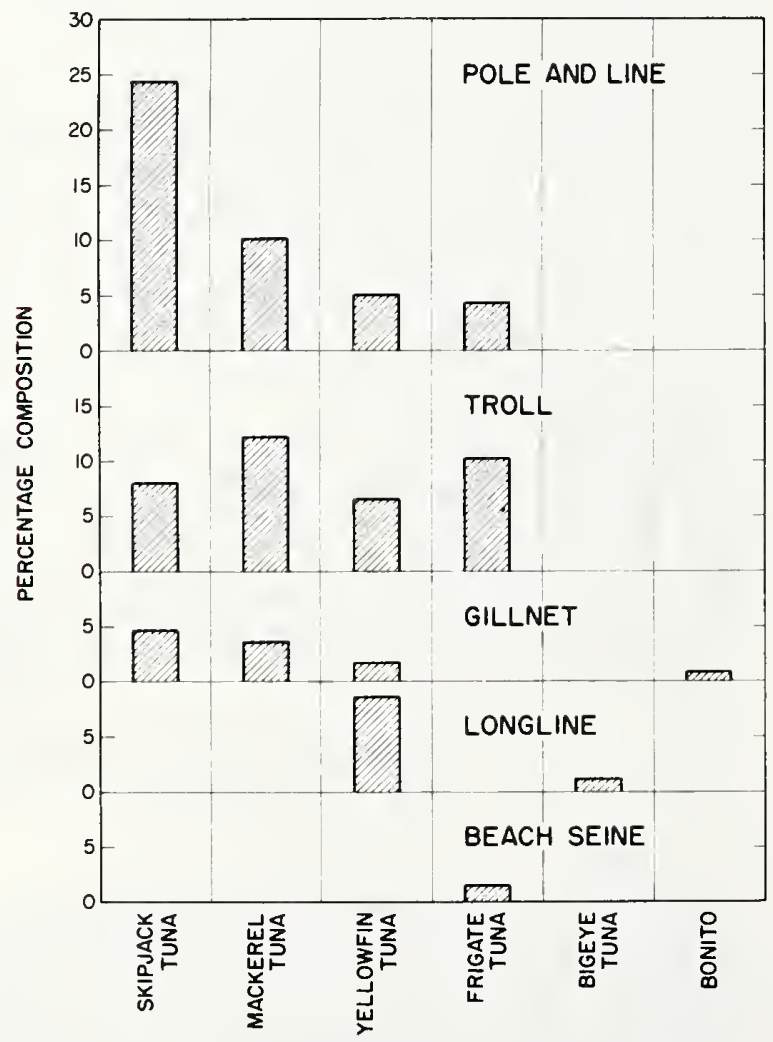

Figure 50.-Percentage composition of tuna species caught by various types of gear from the coastal waters of Sri Lanka (Sivasubramaniam 1965). jack tuna, it is not equally effective for Auxis (Sivasubramaniam 1973). The reason is that Auxis respond poorly to chumming probably because the live bait used are usually larger than the most common food items in their stomachs. Furthermore, this type of fishing is not effective during periods of southwest monsoon, because water turbidity makes baiting difficult.

The best season for pole-and-line fishing is in November-March off the southwest coast and in July-September off the east coast. Tuna production depends heavily on the availability of bait during these periods.

Drift nets are operated around the entire island of Sri Lanka (Sivasubramaniam 1973). A 3.5-gross ton boat usually carried 15 pieces of netting whereas as 11 -gross ton boat carried 60 pieces. With mesh sizes varying from 10.2 to $14.0 \mathrm{~cm}$, the synthetic drift net has proven effective for skipjack and large kawakawa. For Auxis, however, fish $<30 \mathrm{~cm}$ in length are too small to be enmeshed. The catch of Auxis, therefore, amounts to only about $18 \mathrm{~kg} /$ day for a 3.5 -gross ton boat and about $54 \mathrm{~kg} /$ day for an 11-gross ton boat. Auxis rochei, being smaller, are very rare in drift net catches. Auxis are usually taken by drift net from about September to March.

\subsection{Boats}

As with gear, a wide variety of fishing boats, ranging from modern high-seas purse seiners and pole-and-line boats to primitive sailing crafts, is used in fishing for Auxis.

In Japanese waters, the pole-and-line boats that are engaged in the Auxis fishery are small, usually $<15$ gross tons (Ishida 1972a). These boats are smaller than the usual pole-and-line boats of $>30$ gross tons which fish in the coastal waters and high seas for surface schools of tunas such as skipjack tuna, yellowfin tuna, and albacore. Japanese pole-and-line boats that fish in the Atlantic for yellowfin and skipjack tunas and occasionally for Auxis and bigeye tuna vary from 151 to 239 gross tons, whereas the seiners, both single and double boats, range from 50 up to $>400$ gross tons (Borgstrom 1964; Hayasi 1973, 1974).

Among the more primitive types of crafts used in Auxis fishing are dugout canoes and catamarans (Silas 1967b). In the Maldive Islands, for example, sailing boats called vadu dhony, which are about $6.1 \mathrm{~m}$ long and $1.8 \mathrm{~m}$ wide, and fish three to four baited trolling lines, are used as trollers (Sivasubramaniam ${ }^{10}$ ). Slightly larger sailing crafts, called the mas dhony, are used in pole-and-line fishing; they vary in length from 10.7 to $12.2 \mathrm{~m}$, have a beam of about $3.4 \mathrm{~m}$ and a draft of nearly $0.8 \mathrm{~m}$. The Maldivian boats are constructed of coconut wood, beautifully streamlined, and keeled for windward sailing. Compartments for carrying live bait have continuous water circulation through holes along the bottom. The fishermen fish at the stern atop a U-shaped removable wooden platform.

\footnotetext{
${ }^{10}$ K. Sivasubramaniam, UNDP-Sri Lanka Skipjack Fishery Development Project, FAO, Colombo, Sri Lanka, pers. commun. August 1975.
} 
In 1972, the Maldivian fishing fleet had an estimated 5,100 fishing boats which included 2,980 trollers and 2,100 pole-and-line tuna boats operating within a $46 \mathrm{~km}$ radius of the islands. Skipjack tuna, yellowfin tuna, kawakawa, and Auxis are the main species caught by the pole-and-line boats. Hiebert and Alverson (1971) pointed out that one of the factors hindering the development of the Maldivian tuna fishery is the limited access of the boats to more distant fishing grounds. Lack of refrigeration also precludes long trips; therefore, the tuna boats leave port for the fishing grounds at about 0300 and return late in the evening. The introduction of motorized, refrigerated boats can probably increase the present fish catch 3-4 times.

In waters around Sri Lanka, trolling gear was formerly operated from "orus" or outrigger canoes with sails. Nowadays, however, 3 - to 5 -gross ton motorized boats, manned by a crew of at least three fishermen, are used (Sivasubramaniam 1973). In the Canary Islands where Auxis are landed along with other species of tuna, there are large boats (average $\mathbf{4 0 0}$ gross tons), which have refrigerated holds and carry about 20 men, and smaller, artisanal fishing boats (average 10 gross tons), which are crewed by $4-5$ fishermen, are about $12 \mathrm{~m}$ long and have open decks and bait tanks. Propelled by engines that vary in size from 50 to $120 \mathrm{hp}$, these small boats usually engage in pole-and-line and occasionally purse seine fishing.

Off Angola, yellowfin and skipjack tunas are the principal species caught by the small, pole-and-line boats, but Auxis are also landed in smaller quantities (De Campos Rosado 1972). These boats, which operate within a narrow strip about $75 \mathrm{~km}$ wide and $370 \mathrm{~km}$ long along the coast, vary in size from 12 to $20 \mathrm{~m}$ long. The Cuban pole-and-line fishery, which lands small amounts of Auxis, operates motorized sailing boats, which have been described as modified sloops with a gaff-rigged mainsail and usually with a flying jib (Rawlings 1953; Wise and Jones 1971).

\subsection{Fishing areas}

\subsection{General geographic distribution}

Almost all the Auxis caught in the Japan Sea are $A$. rochei (Okachi 1958). Percentagewise, Okachi determined that of the fishing areas established for Auxis in Japanese waters, the South Pacific region had $62 \%$ of the catch, the middle Pacific region $22 \%$, and the Japan Sea and East China Sea regions combined only $12 \%$. Catches from west Japan Sea and East China Sea regions were usually similar whereas catches from the north Japan Sea region were smaller than either one.

In other areas of the world, Auxis are usually caught as incidental species. In the Pacific, for example, Auxis are caught incidentally in waters around Taiwan, the Philippines, Thailand, West Malaysia, Hawaii, and Australia (Serventy 1941; Gosline and Brock 1960; Kume 1973; Philippine Bureau of Fisheries 1973). Small numbers of Auxis are also taken in the Indian Ocean.
Jones (1967) reported that Auxis are captured along the coasts of India and in waters surrounding the Maldive Islands (Sivasubramaniam footnote 10). According to Sivasubramaniam (1973), Auxis are caught in waters around Sri Lanka on a commercial scale throughout the year in the south and southwest coast of Sri Lanka.

In the Mediterranean region, the waters around Cyprus, Greece, Italy, Malta, Morocco, Spain, and Yugoslavia are fishing grounds for Auxis. Spanish trapnet fishermen land commercial quantities of Auxis at Barbate on the Atlantic Spanish coast near the Strait of Gibralter, at Tarifa in the middle of the Strait, and at La Linea on the Mediterranean Spanish coast near the entrance of the Strait. Some fishing is also carried on around the Canary Islands (Bas 1967; Cendrero and Garcia-Cabrera 1972).

Auxis are taken in Moroccan waters mostly by trap fishermen. Traps located at Larache and at Cape Spartel are set primarily to catch bluefin tuna that make their spawning migration toward the Mediterranean Sea along the Moroccan coast in April-July. Traps at M'diq in the Mediterranean also capture tuna as they exit after spawning. In traps located along the Atlantic Moroccan coast, Auxis account for only $3 \%$ of the tuna landed, but in those situated along the Mediterranean Moroccan coast, they represent $98 \%$ of the tuna catch (Lamboeuf 1972).

Around Portugal, the tuna fishing grounds are along the north and west coasts where small pole-and-line vessels operate. Other grounds fished by Portuguese fishermen are located off the islands of Azores and Madeira where small- to medium-sized pole-and-line vessels operate, and off Angola (De Campos Rosado 1972; Dias and Barraca 1972). Catches of little tunny, bonito, and Auxis represent roughly $60 \%$ of the total tuna landings from Angola.

Off Ghana, in the Gulf of Guinea, there is another fishing ground for Auxis. Although most of the tuna landings at Tema are made by foreign longline, poleand-line, and purse seine vessels, Ghana's canoes and motorized fishing crafts also account for some of the landings of tuna and tunalike fishes (Di Palma 1968).

In the western Atlantic, Auxis were previously taken along the east coast of the United States. Pound nets fished along the Middle Atlantic States during the 1940's and early 1950's frequently caught Auxis along with bluefin tuna, little tunny, and bonito (Anderson et al. 1953). Southward, the waters around Cuba, off Venezuela, and off Brazil also yield small quantities of Auxis.

\subsection{Geographic ranges}

See section 5.21 .

\subsection{Depth ranges}

Adult $A$. thazard has been reported to distribute themselves vertically from the surface down to a depth of about $45 \mathrm{~m}$ (Kiskinouye 1923). 


\subsection{Fishing seasons}

\subsection{General pattern of seasons}

The average monthly landings of Auxis at Tosashimizu (Kochi Prefecture), at Hachijo (Izu Archipelago), and at Mera (Shizuoka Prefecture) are shown in Figure 51. At Tosashimizu, where a pole-andline fishery operates, Auxis are caught throughout the year, but peak fishing usually extends from October through May (Yasui 1975). During the remainder of the year (June-September), some of the pole-and-line boats concentrate on other species; therefore, there is a reduction in fishing effort for Auxis.

In the region of the South China Sea, the fishing season for Auxis varies considerably. For example, in the Philippines, the fishing season varies for different parts of the island group beginning at any time between November and January and extending into May (Philippine Bureau of Fisheries 1973). In Thailand and West Malaysia, however, the landings of Auxis, Euthynnus affinis, and Thunnus tonggol are usually better during the latter half of the year (Kume 1973).

Fishing for $A$. thazard in Indian waters begins about August and extends to about December (Nair et al. 1970). Sivasubramaniam (1973), who examined the
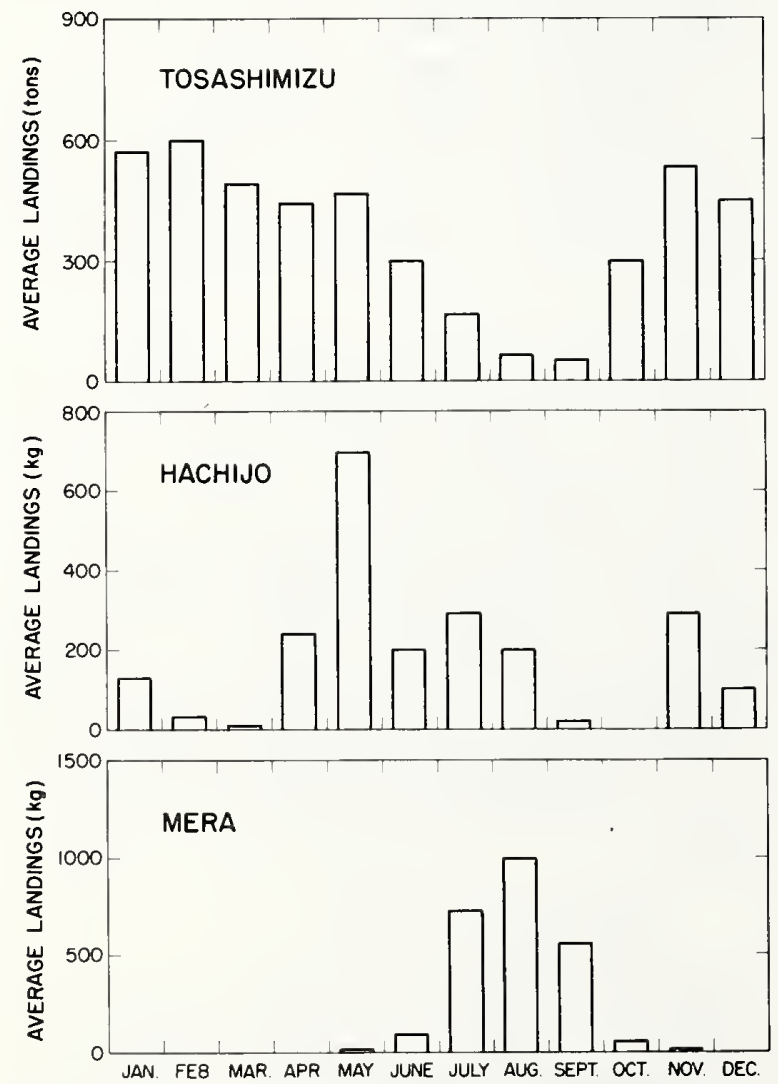

Figure 51.-Landings of Auxis spp. average by month from catches made between January 1969 to December 1976 at Tosashimizu, between January 1969 and October 1974 at Hachijo, and between January 1967 and December 1974 at Mera, Japan (Yasui 1975). seasonal and annual variations in the catches of frigate tuna from waters surrounding Sri Lanka, observed that in the south and southwest coasts, $A$. thazard are caught throughout the year but in the east and north coasts, they are caught primarily in June-September and lesser amounts in March-April.

In the Maldives, catches of Auxis, combined with that of kawakawa, peak at least twice a year (Hiebert and Alverson 1971). In 1965, for example, combined catches of Auxis and kawakawa in the Maldives peaked in January at 1.2 million fish, declined sharply in February-May to $<0.6$ million, then fluctuated irregularly until September after which the catch rose to a second minor peak in November before declining again in December.

At Barbate, Spain, A. rochei appear in the trap catches in May-July with the heaviest catches occurring in the first 2 months. About $53 \%$ of the catch is composed of $A$. rochei and the remainder consists of little tunny and bonito (Rodriguez-Roda 1966). At Tarifa, bullet tuna constitute $95 \%$ of the trap catches and average $67.1 \mathrm{t}$ annually. Here, the trap fishery is active in May-June. The traps at La Linea make the largest catches of small tunas with $A$. rochei accounting for $97 \%$ of the catches. The fishing season extends from August to October but most of the catches are made in the first 2 months.

\subsection{Dates of beginning, peak, and end of season}

See section 5.31.

\subsection{Variation in date or duration of season}

At Tosashimizu, Japan, where a pole-and-line fishery for $A$. rochei operates, severe fluctuations in the monthly landings usually occur in October-December whereas landings are stable in January-March (Yasui 1975). Yasui examined the relationship between seasurface temperature and monthly landings and found that in years of good fishing, there was a complex distribution of surface temperature with $28^{\circ} \mathrm{C}$ water very close to shore (Fig. 52A), whereas in years of poor fishing the warm water was displaced farther offshore (Fig. $52 \mathrm{~B})$. He concluded that the location of the $28^{\circ} \mathrm{C}$ isotherm in July-September significantly influenced fishing conditions in subsequent months. Temperature, it appeared, affects the concentration of bullet tuna schools, i.e., their availability to the boats and the length of their stay on the fishing grounds.

Monthly landings at Mera, where the fish are taken by nets, show that peak fishing occurs in July-September (Fig. 51). Yasui (1975) noted that in this fishery, the large, mature fish with high reproductive index are usually taken in June and that progressively smaller fish are taken in subsequent months. The proportion of immature fish in the catch increased in July-August and by September all fish were immature. Yasui concluded from these findings that the catch of Auxis at Mera is in- 


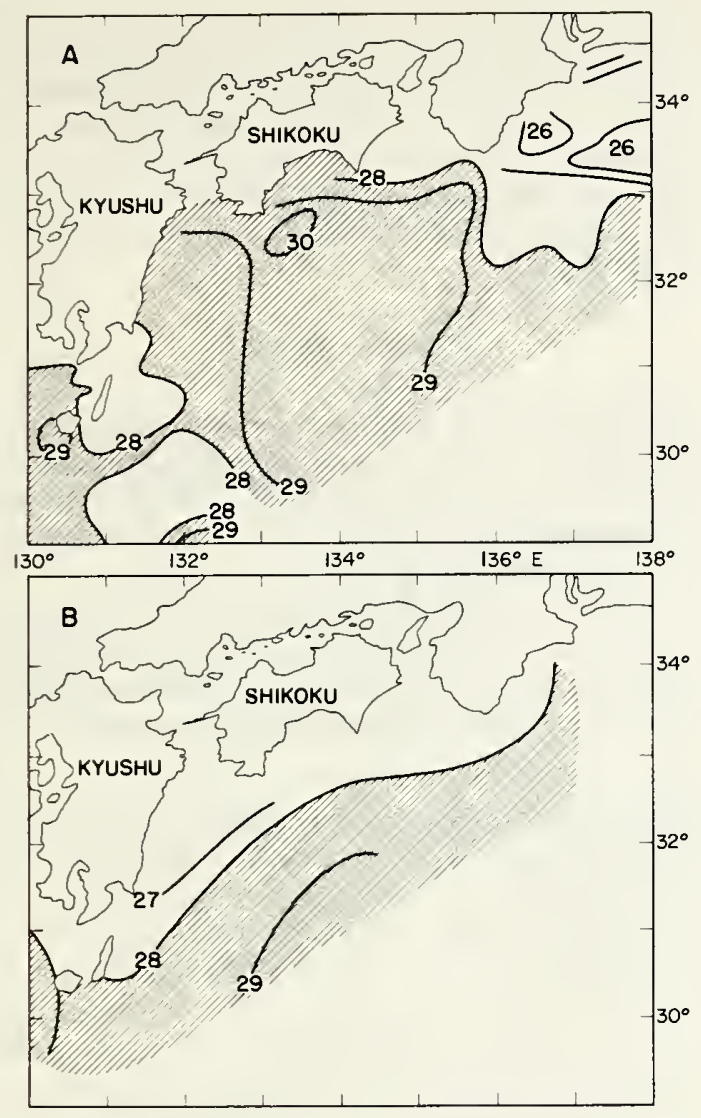

Figure 52.-Distribution of surface temperatures in JulySeptember in years of good (A) and poor (B) fishing for Auxis rochei at Tosashimizu, Kochi Prefecture, Japan (Yasui 1975).

fluenced to a large extent by a seasonal in-migration of fish from the west and south.

At Hachijo, where Auxis are landed by surface trollers, catches are made throughout the year except in October (Fig. 51). Yasui (1975) observed that there are two seasons for Auxis at Hachijo-one in April-August and another in November-January. The appearance of Auxis in April-May at Hachijo coincides with the end of the gill net fishery for flyingfish, which are preyed on by Auxis. Yasui also noted that sexually mature fish appear in the catches in April-May followed by larger, older fish in July.

At Ashizurimisaki in Kochi Prefecture, Ishida (1972b) noted considerable fluctuations in landings of Auxis. To determine the possibility of predicting the degree of success of a fishing season, Ishida, using data for 1952-67., obtained the following:

$$
\begin{aligned}
C_{\mathrm{J}} & =\text { catch in October-March in year } j \\
C_{\mathrm{J}+1} & =\text { catch in October-March in year } j+1 \\
\Delta C_{\mathrm{J}+1} & =\text { difference between } C_{\mathrm{J}} \text { and } C_{\mathrm{J}+1} .
\end{aligned}
$$

Plotting $C_{\mathrm{j}}$ against $\Delta C_{\mathrm{j}+1}$, Ishida found that when $C_{\mathrm{j}}$ was small, $\Delta C_{\mathrm{J}+1}$ tended to be positive and vice versa. Ishida also noted that larger catches of Auxis tended to be associated with cooler temperatures. Yamashige
(1974), on the other hand, found a positive relatonship between catches of $A$. rochei in August-July and the difference in the mean surface temperature between August and October of a given year, and he described the relationship between these two variables as follows:

$$
Y=1.42+1.15\left(t_{8}-t_{10}\right)
$$

where $Y=$ catch, in $1,000 \mathrm{t}$, from August ( $n$ year) to July $(n+1$ year $)$

$t_{8}=$ mean surface temperature in August at Ashizurimisaki $\left({ }^{\circ} \mathrm{C}\right)$.

$t_{10}=$ mean surface temperature in October at Ashizurimisaki $\left({ }^{\circ} \mathrm{C}\right)$.

In Sri Lanka, the mechanization of fishing boats made fishing possible even during periods of monsoons and has been primarily responsible for a shift in the fishing season. Originally, Williams (1963) reported that the main fishing season for Auxis in Sri Lanka extended from October or November to May. Sivasubramaniam (1973), however, found that Williams defined the fishing season by examining catches made during the north. east and intermonsoons when beach seines are usually in operation. Excellent fishing occurs in all fishing areas around Sri Lanka particularly during the end of the southwest monsoon. Sivasubramaniam observed that this period is associated with heavy recruitment and vulnerability of the recruits to trolling gear. The result is that the number of fish caught per day rises abruptly, but the net tonnage landed. does not rise proportionately.

\subsection{Fishing operation and results}

\subsection{Effort and intensity}

In the Auxis fishery off Ashizurimisaki in Kochi Prefecture, Japan, fishing intensity (the number of small, 3 -gross ton pole-and-line boats operating per day) varies widely from as few as 10 to as many as 260 boats/day (Ishida 1972a). Fishing intensity usually peaks once in March and again in November to about 200 boats/day. During the balance of the fishing season, which extends usually from October to May, however, the average number operating is about 170 boats/day.

\subsection{Selectivity}

Although pole-and-line fishing is effective for skipjack and yellowfin tunas, it is not equally effective for Auxis. Sivasubramaniam (1973) observed that in Sri Lanka, Auxis respond poorly to chumming probably because the live bait used is larger than the most common food items in their stomachs.

The drift net, which is in operation around the entire island of Sri Lanka, is also ineffective at times particularly for Auxis $<30 \mathrm{~cm}$. It is, however, effective for skipjack and large kawakawa. Catches of Auxis by drift nets, therefore, amount to only about $18 \mathrm{~kg} /$ day for a 3.5 - 
gross ton boat and about $54 \mathrm{~kg} /$ day for an 11-gross ton boat. Auxis rochei, being smaller, are very rare in drift net catches.

\subsection{Catches}

Total catches of frigate and bullet tunas by various countries in the Atlantic (including the Mediterranean Sea), Pacific, and Indian Oceans in 1953-76 are given in Table 26. By far, the total catch in the Pacific was the largest among the three oceans, averaging $40,700 \mathrm{t}$ annually. The Atlantic and Indian Ocean catches, on the other hand, averaged about $13.8 \mathrm{t}$ in each ocean or about a third of the Pacific catch.

In the Report of the Ad Hoc Committee Meeting of Specialists to Review the Biology and Status of Stocks of Small Tunas, it was pointed out that the catches of Auxis reported by the various countries do not truly reflect the abundance of the two species in the world's ocean. For example, purse seine fishermen avoid catching Auxis because they are a nuisance as many become gilled in the net and require considerable time and manpower to remove. Furthermore, the catches of Auxis by tuna seiners are often discarded at sea. Other difficulties noted with Auxis catch statistics are that artisanal catches are usually not fully reported and that there is confusion and inclusion of Auxis with other species.

\section{Pacifc Ocean}

Japan lands, by far, more Auxis than any other country and is, in fact, the only country that has a wellestablished commercial fishery. In 1953-76, the catch of Auxis averaged $24,300 \mathrm{t}$, varying from $14,900 \mathrm{t}$ in 1975 to $48,300 \mathrm{t}$ in 1963 (Table 26).

In Taiwan, the catches of frigate and bullet tunas in 1961-73 varied between 600 and 1,200 $\mathrm{t}$ and averaged $1,000 \mathrm{t}$ (Table 26). Perhaps it should be pointed out that there is a discrepancy in the catch statistics for frigate

Table 26.-Estimated catches of Auxis sp. by countries, 1953-76 (in units of 1,000 metric tons). (Data compiled from FAO 1959, 1964, 1969, 1974, 1977; Lamboeuf 1972; Miyake and Tibbo ${ }^{1}$; Miyake et al. ${ }^{2}$; Sivasubramaniam ${ }^{3}$; Hagborg. ${ }^{4}$ - $=$ data not available; $0.0=$ magnitude negligible or insignificant.

\begin{tabular}{|c|c|c|c|c|c|c|c|c|c|c|c|c|c|c|c|c|c|c|c|c|c|c|c|}
\hline \multirow[b]{2}{*}{ 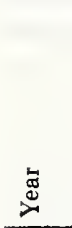 } & \multicolumn{12}{|c|}{ Atlantic Ocean (including Mediterranean Sea) } & \multicolumn{4}{|c|}{ Pacific Ocean } & \multicolumn{7}{|c|}{ Indian Ocean } \\
\hline & $\begin{array}{l}\frac{\pi}{8} \\
8 \\
\frac{8}{4}\end{array}$ & 号 & $\frac{\text { 罵 }}{\text { 胥 }}$ & 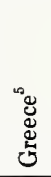 & 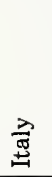 & 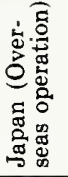 & 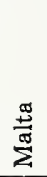 & $\begin{array}{l}\stackrel{\circ}{8} \\
0 \\
0 \\
\vdots \\
\Sigma\end{array}$ & 路 & 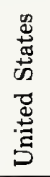 & 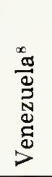 & 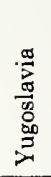 & 茎 & 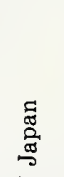 & 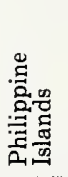 & $\underset{\infty}{\mathbb{D}}$ & 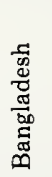 & $\stackrel{\infty}{\mathscr{D}}$ & 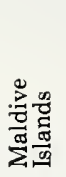 & 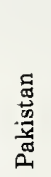 & 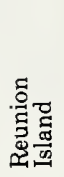 & 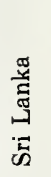 & 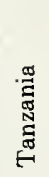 \\
\hline 1953 & 6.4 & - & - & 0.8 & - & - & 一 & 4.0 & 2.0 & - & 1.2 & - & - & 15.6 & - & - & - & - & - & - & - & - & - \\
\hline 1954 & 7.3 & - & - & 0.6 & - & - & - & 1.4 & 4.0 & - & 1.3 & 0.1 & - & 20.6 & - & - & - & - & - & - & - & - & - \\
\hline 1955 & 5.2 & - & - & 1.2 & - & - & - & 4.0 & 4.8 & - & 1.3 & 0.2 & - & 23.4 & - & - & - & - & - & - & - & - & - \\
\hline 1956 & 1.8 & - & - & 0.9 & - & - & - & 2.4 & 3.4 & - & 1.1 & 0.1 & - & 25.9 & - & - & - & - & - & - & - & - & - \\
\hline 1957 & 1.1 & - & - & 0.5 & - & - & - & 2.5 & 5.4 & - & 1.0 & - & - & 20.4 & - & - & - & - & - & - & - & - & - \\
\hline 1958 & 2.5 & - & - & 0.7 & 0.4 & - & - & 3.0 & 10.0 & - & 1.2 & 0.1 & - & 23.3 & - & - & - & - & - & - & - & - & - \\
\hline 1959 & 1.9 & - & - & 0.7 & 0.7 & - & - & 1.0 & 3.8 & - & 1.7 & 0.1 & - & 19.9 & - & - & - & - & - & - & - & - & - \\
\hline 1960 & 1.9 & - & - & - & 0.6 & - & - & 1.8 & 5.2 & - & 1.3 & 0.0 & - & 15.8 & - & - & - & - & - & - & - & - & - \\
\hline 1961 & 2.7 & - & - & - & 1.0 & - & - & 0.2 & 3.4 & - & 0.8 & 0.0 & - & 18.2 & - & 0.7 & - & - & - & - & - & - & - \\
\hline 1962 & 1.6 & - & - & - & 0.7 & - & - & 0.6 & 4.4 & - & 1.0 & 0.0 & - & 21.1 & - & 0.8 & - & - & - & - & - & - & - \\
\hline 1963 & 1.3 & - & - & - & 0.8 & - & - & 1.6 & 3.1 & - & 1.0 & 0.0 & - & 48.3 & - & 0.6 & - & - & - & - & - & - & - \\
\hline 1964 & 0.9 & - & - & 0.6 & 0.5 & - & - & 1.5 & 2.5 & - & 1.4 & 0.0 & 5.3 & 26.9 & 9.1 & 1.1 & 0.8 & 2.4 & 1.5 & 1.1 & - & 4.0 & - \\
\hline 1965 & 1.7 & 0.0 & 2.0 & 0.7 & 0.7 & 0.9 & 0.0 & 1.8 & 2.5 & - & 1.8 & 0.0 & 4.8 & 29.8 & 12.4 & 0.8 & 0.4 & 2.0 & 2.5 & 1.2 & - & 4.5 & - \\
\hline 1966 & 1.4 & 0.0 & 2.0 & 0.5 & 0.9 & 0.4 & 0.0 & & 2.3 & - & 1.4 & 0.0 & 4.0 & 29.3 & 16.4 & 1.2 & 0.3 & 2.0 & 3.0 & 1.5 & - & 4.5 & - \\
\hline 1967 & 1.2 & 0.0 & 2.0 & 0.6 & 1.2 & 0.6 & 0.0 & 1.2 & 3.5 & - & 1.1 & 0.0 & 4.4 & 28.7 & 10.5 & 0.8 & 0.1 & 1.7 & 3.0 & 1.3 & - & 5.0 & - \\
\hline 1968 & 0.6 & 0.0 & 1.8 & 0.5 & 1.2 & 1.6 & 0.0 & 0.9 & 1.7 & - & 0.4 & 0.0 & 3.2 & 21.0 & 19.5 & 0.4 & 0.1 & 2.3 & 3.0 & 1.3 & - & 5.0 & - \\
\hline 1969 & 0.8 & 0.0 & 3.0 & - & 1.1 & 3.2 & 0.0 & 0.6 & 2.0 & - & 0.4 & 0.1 & 3.2 & 24.1 & 14.8 & 0.4 & 0.2 & 1.9 & 3.0 & 1.0 & - & 5.5 & - \\
\hline 1970 & 0.5 & 0.0 & 3.0 & - & 1.1 & 3.1 & 0.0 & 1.0 & 2.2 & - & 0.7 & 0.0 & 2.4 & 25.9 & 9.6 & 0.7 & 0.7 & 7.9 & 1.7 & 5.5 & 0.1 & 5.0 & - \\
\hline 1971 & 1.1 & 0.0 & 2.7 & - & 1.6 & - & 0.0 & 0.3 & 3.8 & - & 0.5 & 0.0 & 2.6 & 20.1 & 9.9 & 0.5 & 0.7 & 0.2 & 1.8 & 5.6 & 0.2 & 3.2 & 0.4 \\
\hline 1972 & 1.6 & 0.0 & 5.3 & - & 1.7 & 0.0 & 0.0 & 0.5 & 1.9 & - & 0.6 & 0.0 & - & 31.1 & 10.6 & 0.6 & 0.5 & 0.2 & 3.1 & 4.9 & 0.2 & 4.1 & 0.6 \\
\hline 1973 & 1.1 & 0.0 & 2.3 & - & 1.2 & 1.2 & 0.0 & 1.6 & 1.9 & - & 0.7 & 0.0 & - & 33.5 & 13.0 & 0.7 & - & 0.2 & 6.2 & 5.4 & - & 3.8 & - \\
\hline 1974 & 1.5 & 0.0 & 6.3 & - & 1.3 & 0.5 & 0.0 & 0.5 & 0.6 & 0.0 & 0.9 & 0.0 & - & 26.2 & 5.0 & - & - & - & 5.9 & - & - & - & - \\
\hline 1975 & 0.5 & 0.0 & 6.0 & - & 0.9 & 0.0 & 0.0 & 0.1 & 0.5 & 0.0 & 1.0 & 0.0 & - & 14.9 & 7.6 & - & - & - & 3.9 & - & - & - & - \\
\hline 1976 & 0.5 & 0.0 & 4.3 & - & 0.9 & 0.0 & 0.0 & 0.4 & 0.5 & 0.0 & 1.2 & 0.0 & - & 20.2 & 14.0 & - & - & - & 2.7 & - & - & - & - \\
\hline Mean & 2.0 & 0.0 & 3.4 & 0.7 & 1.0 & 1.2 & 0.0 & 1.4 & 3.1 & 0.0 & 1.0 & 0.0 & 3.7 & 24.3 & 11.7 & 1.0 & 0.4 & 2.1 & 3.2 & 2.9 & 0.2 & 4.5 & 0.5 \\
\hline
\end{tabular}

${ }^{1}$ Miyake, M. P., and C. G. Tibbo (compilers. 1972. Statistical bulletin.

International Commission for the Conservation of Atlantic Tuna ST/Total/72/2-10-11. [No pagination.]

${ }^{z}$ See text footnote 12

${ }^{3}$ See text footnote 11 .

${ }^{4}$ D. W. Hagborg, Fishery Resources \& Environment Division, Food and Agriculture Organization of the United Nations, Rome, Italy, pers. commun. February 1975 .

${ }^{5}$ Includes bluefin tuna.

${ }^{6}$ Includes Atlantic bonito.

${ }^{7}$ Includes catches from Ceuta in 1954-58.

${ }^{8}$ Includes Atlantic bonito in 1965-67.

${ }^{9}$ Probably includes several other species of tuna and tunalike fishes in 1964-70. 
and bullet tunas from Taiwan for 1961-68. Examination of the catch statistics from Taiwan for 1958-63 (FAO 1964) showed catches to be rather high. In 1961-63, for example, they were as follows:

$\begin{array}{cc}\text { Year } & \text { Catch (1,000 metric tons) } \\ & \\ 1961 & 11.9 \\ 1962 & 18.2 \\ 1963 & 15.1\end{array}$

But in FAO (1967), the frigate and bullet tuna catches in 1961-63 were given as follows:

$\begin{array}{cc}\text { Year } & \text { Catch (1,000 metric tons) } \\ & \\ 1961 & 0.7 \\ 1962 & 0.8 \\ 1963 & 0.6\end{array}$

Further research into the method of compiling catch statistics indicated that data from FAO (1964) included other species under frigate and bullet tunas. Kume (1973) revealed that Taiwan uses a categroy called "bonito" in which are included Auxis as well as kawakawa and perhaps other small tunas. Kume gave the "bonito" catch for 1970 as $15,500 \mathrm{t}$ but estimated that of this total, only $778 \mathrm{t}$ or roughly $5 \%$ were Auxis. Furthermore, the frigate and bullet tuna catches in 1961-63, as given in FAO (1967), amounts to only $4-6 \%$ of the catches as given in FAO (1964). Therefore, it can be presumed that roughly $5 \%$ of the catches of frigate and bullet tunas in Taiwan, as given in FAO (1964), are actually of this species with the remainder constituting catches of other small tunas.

Southward, in the South China Sea region, the Philippines, Sabah, Sarawak, Thailand, and West Malaysia also harvest Auxis. In the Philippines, catches of Auxis in 1964-76 varied from 5,000 $\mathrm{t}$ in 1974 to $19,500 \mathrm{t}$ in 1968 and averaged $11,700 \mathrm{t}$ (Table 26). The Thailand landings of Auxis, Euthynnus affinis, and Thunnus tonggol are combined and called "bonito" or "pla o" locally in the catch statistics (Kume 1973). In 1971, Thai and Chinese seiners landed $5,090 \mathrm{t}$ or $78 \%$ of the $6,548 \mathrm{t}$ of "bonito" reportedly caught in Thailand. In West Malaysia, landings of Auxis are also combined with those of $E$. affinis and $T$. tonggol. The 1958-71 production of these three species combined varied between 789 $\mathrm{t}$ in 1959 and 5,578 $\mathrm{t}$ in 1967 and averaged 3,131 $\mathrm{t}$ annually. Table 26 shows that the catches of Auxis from China mainland varied from 2,400 to $5,300 \mathrm{t}$ in 1964-71 and averaged $3,700 \mathrm{t}$.

\section{Indian Ocean}

In addition to $E$. affinis and $T$. Tonggol, which are the two most common tuna species landed from Indian waters, small numbers of Auxis are also captured in the tuna fishery along the coast of India (Jones 1967). Of the two species, $A$. thazard are more common whereas $A$. rochei are rarely seen in the commercial catch. Thomas (1967) reported that Auxis are taken in the Laccadive Islands, but catches are usually recorded in the category, "other fishes," which includes $E$. affinis, Acanthocybium solandri, Istiophorus gladius, Elagatis bipinnulatus, Caranx sp., Chorinemus sp., and sharks. Sivasubramaniam ${ }^{11}$ estimated that Auxis catches in India account for about $5 \%$ of the tuna and tunalike catches. It is also apparent from the data that the west coast of India usually yields Auxis catches that are about 5 times more than those from the east coast. In 1964-73, India's Auxis catches varied between 200 and $7,900 \mathrm{t}$ and averaged 2,100 $\mathrm{t}$ annually (Table 26).

The tuna fishery in the Maldives is carried out by sailing boats; therefore, fluctuations in the catches are associated with various environmental conditions such as wind direction and velocity and ocean surface currents. In 1964-76, the catches of Auxis from the Maldives fluctuated between $1,500 \mathrm{t}$ in 1964 and 6,200 $\mathrm{t}$ in 1973 and averaged $3,200 \mathrm{t}$ annually (Table 26 .) There are, however, serious discrepancies in the catch statistics. For 1970 and 1971, for example, Sivasubramaniam (see footnote 11) gave the catch of Auxis from the Maldives as 1,700 and $1,800 \mathrm{t}$, respectively. Data from a tuna canning plant project, however, indicate catches of 3,094 t in 1970 and 26,871 $t$ in 1971. Based on landings in 196569 and in 1972-73, it appears that the 1971 catch of $26,871 \mathrm{t}$ is unreasonably high. Furthermore, FAO (1974) estimated the 1970 frigate and bullet tuna catch to be $20,000 \mathrm{t}$ and the 1971 catch as $26,900 \mathrm{t}$, also unreasonably high; therefore, until these discrepancies can be resolved, data from Sivasubramaniam (see footnote 11) will be accepted provisionally.

In waters around Sri Lanka, Auxis are caught on a commercial scale from all the main fishing grounds (Sivasubramaniam 1973). Being the smallest member of the tuna and tunalike fishes, Auxis contribute only 15$20 \%$ to the total catch, by weight, but are the most abundant of all the tuna varieties in the waters around Sri Lanka. Sivasubramaniam reported that although both species appear in the commercial catches, $A$. thazard contributes $92 \%$ and $A$. rochei $8 \%$ to the total annual production. In 1964-73, Sri Lanka's production of frigate and bullet tunas ranged between 3,200 and $5,500 \mathrm{t}$ and averaged $4,500 \mathrm{t}$ annually (Table 26). Percentagewise, they constituted more than a third of the catch of tuna and tunalike fishes from Sri Lanka in 1964-67. The proportion fell to about a fourth in 1968-69, one fifth in 1970, and has been about one-sixth of the total production since 1971 .

Other countries that harvest Auxis in the Indian Ocean include Bangladesh, Pakistan, Reunion Island, and Tanzania. Table 26 shows that in 1964-72, Auxis catches in Bangladesh fluctuated between 100 and $800 t$ and averaged $400 \mathrm{t}$. In Pakistan, catches in 1964-73

\footnotetext{
"Sivasubramaniam, K. 1974. More recent information on the tuna fishery in Sri Lanka, India and the Maldive Islands. Indo-Pacific Fishery Council/Indian Ocean Fishery Commission Ad Hoc Working Group. Nantes, France, 16-18 September 1974. (IPFC/IOFC/WPU4/12, 4 p.
} 
varied from 1,000 to 5,600 $\mathrm{t}$ and averaged 2,900 $\mathrm{t}$ annually. Catches from the Reunion Island, recorded for 197072 , are relatively small, varying between 100 and $200 \mathrm{t}$ and an annual average of about $200 \mathrm{t}$. Tanzania landed $400 \mathrm{t}$ in 1971 and $600 \mathrm{t}$ in 1972 and averaged $500 \mathrm{t}$ for these 2 years.

\section{Atlantic Ocean}

In the Atlantic, Spain, which annually lands about 3,500 t of Auxis, exploits mackerel, Scomber scombrus; bluefin tuna; bonito, Sarda sarda; and occasionally albacore along the Mediterranian Spanish coast (Bas 1967). Mackerel are caught by ring net and trawl; bluefin tuna, bonito, and Auxis are caught occasionally by very large ring nets. The annual production of Auxis by large ring nets is small, ranging between 274 and 2,500 $\mathrm{t}$. The most important gear is the trap. At Barbate, $A$. rochei appear in the traps in May-July and catches average $15.6 \mathrm{t}$ but larger catches usually occur in MayJune (Rodríguez-Roda 1966). Little tunny and bonito are also taken at Barbate, but $A$. rochei predominate, accounting for about $53 \%$ of the production. The traps at La Linea make the largest catches of these small tunas with $A$. rochei constituting about $97 \%$ of the catches $(216 \mathrm{t})$. At Tarifa, $95 \%$ of the catch is $A$. rochei and production averages about $67.1 \mathrm{t}$. The annual catches of $A$. rochei by traps throughout Spain vary widely. Catches at Barbate in some years are very low and fall below 2,000 fish/yr but in other years they may be very high. Table 26 gives the annual production of Auxis in Spain and Table 27 gives a partial breakdown of the catches by type of gear. In 1953-76, the annual landings varied from 500 to $10,000 \mathrm{t}$ and averaged $3,100 \mathrm{t}$ (Rodriguez-Roda 1966, 1967).

Auxis are taken in Moroccan waters mostly by trap fishermen, but surface gear is also employed (Table 27). Lamboeuf (1972) stated that both bait boats and seiners operate as a team in fishing. The bait boat, which is usually an old, low tonnage sardine boat converted to carry bait, chums fish to the surface and keeps them there long enough for the seiner to set the net around the school. Lacking such a bait boat frequently results in an unsuccessful purse seine set. Along the Atlantic Moroccan coast, boats landed $69 \%$ of the Auxis whereas traps contributed less than half or $31 \%$ (Lamboeuf 1973). Along the Mediterranean Moroccan coast, however, traps contributed $91 \%$ of the Auxis landed with the remaining $9 \%$ produced by boats. In 1953-76, the annual catches of Auxis fluctuated between 100 and 4,000 t and averaged 1,400 t (Table 26). Auxis landings in Morocco rose from about $15 \%$ to $20 \%$ of the total tuna landings in $1963-65$, fell to about $12 \%$ in 1966 , then rose steadily to about 27\% of the total catch in 1969 (Lamboeuf 1972). The change in the relative importance of Auxis in the total tuna landings resulted from a very sharp decline in bluefin tuna landings in Morocco. It should be noted that slight discrepancies exist in the catch data for Auxis; only $200 \mathrm{t}$ in Table 26 versus a 1969 catch of $588 \mathrm{t}$, according to Lamboeuf (1972).

In Portugal, traps, which are the principal tuna-fishing gear, are usually fished off the southern coast whereas pole-and-line boats operate along the north and west coasts and off the islands of Azores and Madeira (Dias and Barraca 1972). In the Portuguese overseas province of Angola where the yield of tuna is much higher, the fishery is carried on by small, pole-and-line boats (De

Table 27.-Annual catches of Auxis (in units of 1,000 metric tons) in the Atlantic Ocean, by country and type of gear, 1960-74'

\begin{tabular}{|c|c|c|c|c|c|c|c|c|c|c|c|c|c|c|c|c|}
\hline & Type of gear & 1960 & 1961 & 1962 & 1963 & 1964 & 1965 & 1966 & 1967 & 1968 & 1969 & 1970 & 1971 & 1972 & 1973 & 1974 \\
\hline Total & & 9.0 & 8.1 & 8.3 & 7.9 & 6.8 & 9.3 & 7.1 & 9.2 & 9.5 & 11.0 & 12.3 & 10.7 & 12.8 & 9.3 & (10.7) \\
\hline \multicolumn{17}{|l|}{ By type of gear } \\
\hline Total surface & & 4.2 & 2.8 & 4.3 & 4.3 & 2.6 & 5.1 & 3.4 & 5.8 & 4.7 & 5.5 & 6.2 & 1.1 & 1.5 & 5.9 & $(8.5)$ \\
\hline Bait boats & & - & - & - & 1.3 & 0.9 & 2.6 & 1.8 & 1.8 & 2.2 & 4.0 & 3.1 & 0.2 & 0.2 & 1.2 & $(0.5)$ \\
\hline Purse seiners & & - & - & - & - & - & - & - & 0.4 & 1.3 & 0.2 & 0.7 & 0.8 & 1.2 & 1.8 & - \\
\hline Unspecified & & 4.2 & 2.8 & 4.3 & 3.0 & 1.7 & 2.5 & 1.6 & 3.6 & 1.2 & 1.3 & 2.4 & 0.1 & 0.1 & 2.9 & $(8.0)$ \\
\hline Total traps & & 1.0 & 0.8 & 0.7 & 1.8 & 2.3 & 1.7 & 1.4 & 1.1 & 1.4 & 0.9 & 1.1 & 0.7 & 1.1 & 0.3 & $(0.9)$ \\
\hline Total unclassified & & 3.8 & 4.5 & 3.3 & 1.8 & 1.9 & 2.5 & 2.3 & 2.3 & 3.4 & 4.6 & 5.0 & 8.9 & 10.2 & 3.1 & $(1.3)$ \\
\hline \multicolumn{17}{|l|}{ By country } \\
\hline \multirow[t]{2}{*}{ Ghana } & Purse seine & 一 & - & 一 & - & 一 & - & - & - & - & - & 一 & - & - & 1.6 & - \\
\hline & Unclassified & - & - & - & - & - & - & - & - & 1.8 & 3.0 & 3.0 & 2.7 & 5.3 & - & 6.3 \\
\hline \multirow[t]{2}{*}{ Japan } & Purse seine & - & 一 & - & - & 一 & - & - & 0.4 & 1.3 & 0.2 & 0.7 & 0.7 & 1.2 & 0.2 & 0.0 \\
\hline & Bait boat & - & - & - & - & - & 0.9 & 0.4 & 0.6 & 1.6 & 3.2 & 3.1 & - & 0.0 & 1.2 & 0.5 \\
\hline \multirow[t]{2}{*}{ Morocco $^{2}$} & Traps & 1.8 & 0.2 & 0.6 & 1.2 & 1.4 & 1.2 & 0.6 & 0.6 & 0.8 & 0.1 & 0.5 & 0.2 & 0.4 & 0.3 & 0.4 \\
\hline & Surface gear & - & - & - & 0.5 & 0.1 & 0.5 & 0.1 & 0.6 & 0.1 & 0.1 & 0.5 & 0.1 & 0.1 & 1.3 & 0.1 \\
\hline \multirow[t]{4}{*}{ Portugal (Angola) } & Traps & - & - & - & - & - & - & - & - & - & - & 0.3 & 0.4 & 0.4 & - & - \\
\hline & Bait boat & 1.9 & 2.7 & 1.6 & 1.3 & 0.9 & 1.7 & 1.4 & 1.2 & 0.6 & 0.8 & 0.0 & 0.2 & 0.2 & - & - \\
\hline & $\begin{array}{l}\text { Unclassified } \\
\text { (surface) }\end{array}$ & & & & & & & & & & & & & & & \\
\hline & gear & - & 一 & - & - & - & - & - & - & - & - & 0.2 & 0.5 & 1.0 & 1.6 & 1.6 \\
\hline \multirow[t]{3}{*}{ Spain $^{3}$} & Traps & 1.0 & 0.8 & 0.7 & 0.6 & 0.9 & 0.5 & 0.8 & 0.5 & 0.6 & 0.8 & 0.3 & 0.1 & 0.3 & - & 0.5 \\
\hline & Unclassified & 4.2 & 2.6 & 3.7 & 2.5 & 1.6 & 2.0 & 1.5 & 3.0 & 1.1 & 1.2 & 1.9 & 3.6 & 1.6 & 1.9 & - \\
\hline & Purse seine & - & - & - & - & - & - & - & - & - & - & - & 01 & 一 & - & 一 \\
\hline
\end{tabular}

${ }^{2}$ Data for 1960-62 from Miyake and Tibbo (see footnote 1 in Table 26); for 1963-73 from Miyake et al. (see text footnote 13); for 1974 from Miyake (personal communication with R. S. Shomura, Southwest Fish. Cent., Natl. Mar. Fish. Serv., Honolulu, HI 96812).

${ }^{2}$ Catch in 1960 includes bonito.

${ }^{3}$ Catches in 1960 and 1961 include a small amount of little tunny. 
Campos Rosado 1972). Landings of Auxis from Angola in 1953-76 varied from 500 to $7,300 \mathrm{t}$ and averaged 2,000 $\mathrm{t}$ (Table 26).

Ghana's modern fishing fleet and industry, which developed only since the early 1960 's, are probably the best among African nations (Di Palma 1968). Di Palma observed that confusion exists in the catch statistics on mackerels and scads because some boats do not differentiate between the various species. For example, several species may be reported together including mackerel, Scomber japonicus, various species of horse mackerels of the family Carangidae, Auxis, and mackerel scad, Decapterus rhoncus. Miyake et al. ${ }^{12}$ reported that Ghana's landings of Auxis by unclassified gear varied between 1,800 and $5,300 \mathrm{t}$ and averaged $3,160 \mathrm{t}$ in 196872. In 1965-76, Ghana's annual catch of Auxis varied from 1,600 to 6,300 $\mathrm{t}$ and averaged 3,400 $\mathrm{t}$ (Table 26).

Japan's resurgence as a fishing power after World War II was not restricted to the Pacific and Indian Oceans. Japanese tuna longliners first made their appearance in the Atlantic in 1957 and by 1961 at least 60 vessels were fishing there for yellowfin tuna and albacore (Borgstrom 1964). In 1962, the Japanese placed pole-and-line fishing boats of 239 gross tons each in Ghana to fish for surface schools of tuna. Yellowfin and skipjack tunas are the main species landed by these Japanese bait boats but Auxis and bigeye tuna are also taken in limited quantities (Shomura 1966; Hayasi 1973). Three or four Japanese purse seiners and five to seven pole-and-line (14 in 1972) boats operated in the Atlantic Ocean in 1962-63 and in 1967-72.

Tema, with excellent shore facilities, including cold storage, serves as a base for Japanese purse seiners, pole-and-line boats, and longliners (Di Palma 1968). Auxis as well as yellowfin, skipjack, and bigeye tunas are caught along the coast of Africa and in coastal waters of the offshore islands in the eastern Atlantic.

In 1967-73, Japanese seiners landed from 177 to 1,256 $\mathrm{t}$ of Auxis and averaged $670 \mathrm{t}$ annually (Hayasi 1973, 1974). The proportion of the purse seine tuna catch consisting of Auxis, however, was small varying from $3 \%$ to $15 \%$ in 1969-72.

Auxis catches by Japanese pole-and-line boats also fluctuated widely in 1967-70 varying between 675 and $3,200 \mathrm{t}$ and averaging 1,375 $\mathrm{t}$ annually (Hayasi 1973, 1974). The proportion of the pole-and-line tuna catch which constitutes Auxis varied widely from an insignificant part of the total pole-and-line tuna landings in 1972 to nearly one-third in the 1969 catch.

Japanese boats fish not only in the eastern but also in the western Atlantic Ocean. The Caribbean region is an important fishing ground for tuna and tunalike fishes including Auxis. Wise and Jones (1971) pointed out that the catches of several species of tunas and related fishes occurring in the Caribbean region are shared by several

Miyake, M. P., A. De Boisset, and J. Manning (compilers). 1974. Statistical bulletin. International Commission for the Conservation of Atlantic Tunas, Vol. 4. ST/Total/74/2 - 13-15 Rev. [No pagination.] countries. Japan lands about two-thirds, Cuba and Venezuela each take about one-tenth, and the remaining countries, each with $<2,000 \mathrm{t}$ annually, land the balance of the catch. Among the species landed, yellowfin tuna is the most important, contributing slightly over a third of the total landings. Second most important is the "bonitos" but this category includes few true bonitos and is made up largely of skipjack tuna and blackfin tuna, Thunnus atlanticus, with small amounts of other species such as little tunny and Auxis. Bigeye tuna is third in importance followed by bluefin tuna and albacore. The total landings of Auxis by all Japanese fishing boats operating in the Atlantic varied from 400 to $3,200 \mathrm{t}$ and averaged $1,200 \mathrm{t}$ (Table 26).

In Venezuela, scombrids of commercial interest are Sarda sarda, Auxis, Scomberomorus maculatus (= S. brasiliensis), S. cavalla, and Scomber japonicus (Griffiths 1971). The catches of Sarda and Auxis, primarily by baited hooks ("cordel") and gill nets along eastern Venezuela, are grouped in the official statistics into "cabañas." Unfortunately, the proportion of each species in this category is unknown. Griffiths noted that the proportions may be variable among the fishing areas and also with time. "Cabañas" are usually sold fresh locally or salted and sometimes canned as "tuna" or "bonito." In 1953-76, the landings of Auxis fluctuated between 400 and 1,800 t and averaged 1,000 t (Table 26).

A number of other countries, given in Table 26, lists Auxis as among the species they land. Cyprus, Malta, and Yugoslavia are among them but their landings appear to be insignificant. Greece also lands Auxis, but its annual catches are small and appear to be erratic, varying from 500 to $1,200 \mathrm{t}$ and averaging $700 \mathrm{t}$. Italy's landings are also quite small fluctuating between 400 and $1,700 \mathrm{t}$ and averaging $1,000 \mathrm{t}$ annually.

\section{LITERATURE CITED}

AHLSTROM, E. H.

1971. Kinds and abundance of fish larvae in the eastern tropical Pacific, based on collections made on EASTROPAC I. Fish. Bull., U.S. 69:3-77.

ALVERSON, F. G.

1963. The food of yellowfin and skipjack tunas in the eastern tropical Pacific Ocean. [In Engl. and Span.] Bull. Inter-Am. Trop. Tuna Comm. 7:293-396.

ANDERSON, A. W., W. H. STOLTING, and ASSOCIATES. 1953. Survey of the domestic tuna industry. U.S. Fish Wildl. Serv., Spec. Sci. Rep. Fish. 104, 436 p.

BARRETT, I., and A. A. WILLIAMS.

1965. Hemoglobin content of the blood of fifteen species of marine fishes. Calif. Fish Game 51:216-218.

BAS, C.

1967. La pesca de los escombridos en el litoral Mediterraneo Español. [In Span.] Symp. Scombroid Fishes, Part III. Mlar. Biol. Assoc. India, Symp. Ser. 1:1009-1011.

BATTS, B. S.

1972. Food habits of the skipjack tuna, Katsuu onus pelamis, in North Carolina waters. Chesapeake Sci. 13:193-200.

BELLOC, G.

1954. Les thons de la Méditerraneé. Première note: germon, pélamide et melva. Proc. Tech. Pap. Gen. Fish. Counc. Mledit., FAO 2:283-318. 
BEN-TUVIA, A.

1968. Report on the fisheries investigations of the Israel South Red Sea Expedition, 1962. Sea Fish. Res. Stn. Bull., Israel 52, p. 2155.

BLEEKER, P.

1854. Faunae ichthyologicae japonicae species novae. Natuurkd. Tijdschr. Ned.-Ind. 6:395-426.

1855. Vijfde bijdrage tot de kennis der ichthyologische fauna van Ternate. Natuurkd. Tijdschr. Ned.-Ind. 8:295-304.

BOGOROV, V. G., and T. G. RASS.

1961. On the productivity and the prospects of fishing in the waters of the Indian Ocean. [In Russ.] Okeanologiya 1:107-109.

BORGSTROM, G.

1964. Japan's world success in fishing. Fish. News (Books) Ltd., Lond., $312 \mathrm{p}$.

CADENAT, J.

1950. Poissons de mer du Sénégal. Inst. Fr. Afr. Noire. Initiations Afr. III, $345 \mathrm{p}$.

CENDRERO, O., and C. GARCIA-CABRERA.

1972. Spanish national report. I. Report on tuna fisheries. International commission for the Conservation of Atlantic Tunas. Report for biennial period, 1970-71. Part III:191-193, Madrid.

Cl.EMENS, H. B.

1956. Rearing larval scombrid fishes in shipboard aquaria. Calif. Fish Game 42:69-72.

COLLETTE, B. B.

1978. II. Adaptations and systematics of the mackerels and tunas. In G. D. Sharp and A. E. Dizon (editors), The physiological ecology of tunas, p. 7-39. Acad. Press, N.Y.

COLLETTE, B. B. and L. H. CHAO.

1975. Systematics and morphology of the bonitos (Sarda) and their relatives (Scombridae, Sardini). Fish. Bull., U.S. 73:516-625.

COLLETTE, B. B., and R. N. GIBBS, JR.

1963a. Preliminary field guide to the mackerel- and tuna-like fishes of the Indian Ocean (Scombridae). Smithson. Inst., $48 \mathrm{p}$.

1963b. A preliminary review of the fishes of the family Scombridae. FAO Fish. Rep. 6:23-32.

CUVIER, G.

1829. Le règne animal. Nouvelle ed. tom. II. Deterville, Paris, 406 p.

CUVIER, G., and A. VALENCIENNES

1831. Histoire naturelle des poissons, Vol 8. F. G. Levrault, Paris, $375 \mathrm{p}$.

DAVIES, J. H., and S. A. BORTONE.

1976. Partial food list of three species of Istiophoridae (Pisces) from the northeastern Gulf of Mexico. Fla. Sci. 39:249-253.

De BEAUFORT, L. F., and W. M. CHAPMAN.

1951. The fishes of the Indo-Australian Archipelago. IX. Percomorphi (concluded), Blennoidea. E. J. Brill, Leiden, $484 \mathrm{p}$.

De CAMPOS RASADO, J. M.

1972. Portuguese national report. II. Tuna fisheries in Angola. International Commission for the Conservation of Atlantic Tunas. Report for biennial period, 1970-71. Part III:187-189, Madrid.

de JAGER, B. van D., C. S. de V. NEPGEN, and R. J. van WY'K.

1963. A preliminary report on South African west coast tuna. S. Afr. Sea Fish. Br., Invest. Rep. 47, 40 p.

de SYLVA, D. P

1955. The osteology and phylogenetic relationships of the blackfin tuna, Thunnus atlanticus (Lesson). Bull. Mar. Sci. Gulf Caribb. $5: 1-41$.

DIAS, M. L., and Y. F. BARRACA.

1972. Portuguese national report. I. Considerations on tuna fisheries off the coast of Continental Portugal and the Islands of Madeira and the Azores between 1961 and 1970. International Commission for the Conservation of Atlantic Tunas. Report for biennial period, 1970-71. Part III:181-187, Madrid.

Di PALMA, S.

1968. The fisheries of Ghana. U.S. Wildl. Serv., Foreign Fish. Leafl. $77,74 \mathrm{p}$.

DRAGOVICH, A.

1969. Review of studies of tuna food in the Atlantic Ocean. U.S. Fish Wildl. Serv., Spec. Sci. Rep. Fish. 593, 21 p.
DUCLERC, J., J. SACCHI, C. PICCINETTI, G. PICCINETTIMANFRIN, A. DICENTA, AND J.-M. BARROIS.

1973. Nouvelles données sur la reproduction du thon rouge (Thunnus thynnus L.) et d'autres espèces de thonidés en Méditerranée. [In Fren., Engl. summ.] Rev. Trav. Inst. Pêches Marit. 37:163-176.

EHRENBAUM, E.

1924. Scombriformes. Rep. Dan Oceanogr. Exped. 1908-1910, Medit., II (Biology) A, 11, 42 p.

ERDMAN, D. S.

1962. The sport fishery for blue marlin off Puerto Rico. Trans. Am. Fish. Soc. 91:225-227.

FIEDLER, R. H.

1945. Fishery statistics of the United States, 1941. U.S. Fish Wildl. Serv., Stat. Dig. 7, 174 p.

FITCH, J. E., and P. M. ROEDEL.

1963. A review of the frigate mackerels (genus Auxis) of the world. FAO Fish. Rep. 6:1329-1342

FOOD AND AGRICULTURE ORGANIZATION OF THE UNITED NA TIONS.

1959. Yearbook of fishery statistics, production and fishing craft, 1958. FAO Yearb. Fish. Stat. 9:c32-c38.

1960. Catalogue of the names of fishes of commercial importance in the Mediterranean. FAO, $250 \mathrm{p}$. + index.

1964. Yearbook of fishery statistics, catches and landings, 1963. FAO Yearb. Fish. Stat. 16:c44-c47.

1967. Yearbook of fishery statistics, catches and landings, 1966. FAO Yearb. Fish. Stat. 22:c45-c48.

1969. Yearbook of fishery statistics, catches and landings, 1968. FAO Yearb. Fish. Stat. 26:c47-c50.

1974. Yearbook of fishery statistics, catches and landings, 1973. FAO Yearb. Fish. Stat. 36:412-434.

1976. The biology and status of stocks of small tunas. Report of an Ad Hoc Committee of Specialists, Honolulu, Hawaii, U.S.A., 15-18 December 1975. FAO Fish. Tech. Pap. 154, 21 p.

1977. Yearbook of fishery statistics, catches and landings, 1976. FAO Yeab. Fish. Stat. 42:92-101.

FRADE, F., and E. POSTEL.

1955. Contribution à l'etude de la reproducton des scombroidés et thonidés de l'Atlantique tropical. Rapp. P.-V. Réun. Cons. Perm. Int. Explor. Mer 137:33-35.

FRASER-BRUNNER, A.

1950. The fishes of the family scombroidae. Ann. Mag. Nat. Hist., Ser. 12, 3:131-163.

GILL, T. N.

1862. On the limits and arrangement of the family of scombroids. Proc. Acad. Nat. Sci. Phila. 1862:124-127.

GODSIL, H. C.

1954. A descriptive study of certain tuna-like fishes. Calif. Dep. Fish. Game, Fish. Bull. 97, 185 p.

GORBUNOVA, N. N.

1963. Larvae of scombroid fishes (Pisces, Scombriformes) from the Indian Ocean. [In Russ., Engl. summ.] Tr. Inst. Okeanol. Akad. Nauk SSSR 62:68-95. [Engl. transl. available, U.S. Dep. Commer., Off. Tech. Serv., Wash., D.C.]

1965a. On the distribution of scombroid larvae (Pisces, Scombroidei) in the eastern part of the Indian Ocean. [In Russ., Engl. summ.] Tr. Inst. Okeanol. Akad. Nauk SSSR 80:32-35.

1965b. Seasons and conditions of spawning of the scombroid fishes (Pisces. Scombroidei). |ln Russ., Engl. summ.| Tr. Inst. Okeanol Akad. Nauk SSSR 80:36-61. IEngl. transl. available, U.S. Dep. Commer., Off Tech. Serv.. Wash., D.C.I

1965c. On spawning of scombroid fishes (Pisces, Scombroidei) in the Gulf of Tonkin (South China Sea). [In Russ., Engl. summ.] Tr. Inst. Okeanol. Akad. Nauk SSSR 80:167-176.

1969. Two types of larvae of frigate mackerel of the genus Auxio (Pisces, Scombroidei). Probl. Ichthyol. 9:833-840.

GOSLINE, W. A., and V. E. BROCK.

1960. Handbook of Hawaiian fishes. Univ. Hawaii Press, Honolulu, $372 \mathrm{p}$.

GRIFFITHS, R. C.

1971. The tuna fishery of Venezuela with notes on other scombroids of potential commercial value. In Symposium on 
Investigations and Resources of the Caribbean Sea and Adjacent Regions. FAO Fish. Rep. 71.2:95-109.

GUNTHER, A

1860. Catalogue of the acanthopterygian fishes in the collection of the British Museum, Vol. II. Taylor and Francis, Lond., 548 p.

HAMADA, H., Y. ISHIDA, M. MORITA, Y. TAKEZAWA, S. OKABAYASHI, and I. ISHII.

1973. Investigation of long-corseletted frigate mackerels (Auxis rochei) tagged. [In Jpn.] Rep. Kochi Pref. Fish. Exp. Stn. 69:1327. [Unedited Engl. transl. in files of Southwest Fish. Cent., Natl. Mar Fish. Serv., NOAA, Honolulu, HI 96812.]

HAMADA, H., M. MORITA, Y. ISHIDA, and Y. TAKEZAWA.

1973. Investigation of long-corseletted frigate mackerels (Auxis rachei). [In Jpn.] Rep. Kochi Pref. Fish. Exp. Stn. 69:112. [Unedited Engl. transl. in files of Southwest Fish. Cent., Natl. Mar. Fish. Serv., NOAA, Honolulu, HI 96812.]

1974. Investigation of long-corseletted frigate mackerel (Auxis rochei). [In Jpn.] Rep. Kochi Pref. Fish. Exp. Stn. 70:5-12. [Unedited Engl. transl. in files of Southwest Fish. Cent., Natl. Mar. Fish. Serv., NOAA, Honolulu, HI 96812.]

HARADA, T., O. MURATA, and H. FURUTANI.

1973. On the artificial fertilizaion and rearing of larvae in marusōda, Auxis tapeinosoma. [In Jpn., Engl. synop.] Mem. Fac. Agric. Kinki Univ. 6:113-116.

HARADA, T., O. MURATA, and S. MIYASHITA.

1973. On the artificial fertilization and rearing of larvae in hirasōda, A uxis thazard. [In Jpn., Engl. synop.] Mem. Fac. Agric. Kinki Univ. 6:109-112.

HAYASI, $\mathrm{S}$.

1972. Japanese fisheries and research activities on tunas and tunalike fishes in the Atlantic Ocean, 1970. International Commission for the Consevation of Atlantic Tunas. Report for biennial period, 1970-71. Part III:156-172, Madrid.

1973. Japanese fisheries and research activities on tunas and tunalike fishes in the Atlantic Ocean. 1970 - 1972. International Commission for the Conservation of Atlantic Tunas. Report for biennial period, 1972-73. Part I:126-136, Madrid.

1974. Japanese fisheries and research activities on tunas and tunalike fishes in the Atlantic Ocean, 1971-1973. International Commission for the Conservation of Atlantic Tunas. Report for biennial period, 1973-73. Part II:163-175, Madrid.

HERRE, A. W.

1953. Checklist of Philippine fishes. U.S. Fish Wildl. Serv., Res. Rep. 20, 977 p.

HERRE, A. W., and E. S. HERALD.

1951. Noteworthy additions to the Philippine fish fauna with descriptions of a new genus and species. Philipp. J. Sci. 79:309340.

HIEBERT, R. A., and D. L. ALVERSON.

1971. Harvesting: Experimental fishing and introduction of alternative techniques. FAO Indian Ocean Fishery Commission, Indian Ocean Programme. IOFC/DEV/71/7, p. 15-18.

HIGGINS, B. E.

1970. Juvenile tunas collected by midwater trawling in Hawaiian waters, July-September 1967. Trans. Am. Fish. Soc. 99:60-69.

HOTTA, H.

1955. Seasonal distribution and growth of the "frigate mackerel" Auxis tapeinosoma Bleeker along the Pacific coast of Japan. [In Jpn., Engl. abstr.] Bull. Tohoku Reg. Fish. Res. Lab. 4:120-126.

IDYLL, C. P., and D. P. de SYLVA.

1963. Synopsis of biological data on the frigate mackerel Auxis thazard (Lacépède) 1802 (western Atlantic). FAO Fish. Rep. 6:778-781.

IMAMURA, Y.

1949. The skipjack fishery. [In Jpn.] In Suisan Kòza, The text of the fishery. Jpn. Fish. Assoc. Vol. 6, Fishing section, p. 1794. [Engl. transl., by W. G. Van Campen. 1951. The Japanese skipjack fishery. U.S. Fish Wildl. Serv., Spec. Sci. Rep. Fish. 49, $67 \mathrm{p.}]$

INOUE, M., Y. IWASAKI, R. AMANO, M. AOKI, and M. YAMAUTI. 1970. Ecology of various tuna under captivity-II. Behavior of tuna shown against light and darkness. [In Jpn., Engl. abstr.] J. Coll. Mar. Sci. Technol., Tokai Univ. 4:53-58.
ISHIDA, Y

1971. Investigation of frigate mackerel (Auxis rochei), 1968 season. [In Jpn.] Rep. Kochi Pref. Fish. Expo. Stn. 66 and 67:119140. [Unedited Engl. transl. in files of Southwest Fish. Cent., Natl. Mar. Fish. Serv., NOAA, Honolulu, HI 96812.|

1972a. Frigate mackerel fishery off Ashizurimisaki (Cape Ashizuri) - A consideration of fishing reports. [In Jpn.] Rep. Kochi Pref. Fish. Exp. Stn. 68:37-41. [Unedited Engl. transl. in files of Southwest Fish. Cent., Natl. Mar. Fish. Serv., NOAA, Honolulu, HI 96812.]

1972b. Some consideration on the frigate mackerel fishery off Ashizurimisaki (Cape Ashizuri). [In Jpn.] Rep. Kochi Pref Fish. Exp. Stn. 68:42-51. [Unedited Engl. transl. in files of Southwest Fish. Cent., Natl. Mar. Fish. Serv., NOAA, Honolulu, HI 96812.]

JONES, S.

1958. Notes on the frigate mackerels, Auxis thazard (Lacépede) and A. tapeinosoma Bleeker, from Indian waters. Indian J. Fish. 5:189-194.

1961. Notes on eggs, larvae and juveniles of fishes from Indian waters. VI. Genus Auxis Cuvier. VII. Sarda orientalis (Temminck \& Schlegel). Indian J. Fish. 7:337-347.

1963. Notes on eggs, larvae and juveniles of fishes from Indian waters. XI. Further observations on the genus Auxis Cuvier. Indian J. Fish. 8:413-421.

1963. Synopsis of biological data on the long corseletted frigate mackerel Auxis thynnoides Bleeker 1855. FAO Fish. Rep. 6:782 810.

1967. The scrombroid fishery of India - present and future. Proc. Symp. Scombroid Fishes, Part III. Mar. Biol. Assoc. India, Symp. Ser. 1:994-1000.

JONES, S., and M. KUMARAN.

1963. Distribution of larval tuna collected by the Carlsberg Founda tion's Dana Expedition (1928-30) from the Indian Ocean. FAO Fish. Rep. 6:1753-1774.

1964. Eggs, larvae and juveniles of Indian scombroid fishes. Proc Symp. Scombroid Fishes, Part I. Mar. Biol. Assoc. India, Symp. Ser. 1:343-378.

JONES, S., and E. G. SILAS.

1964. A systematic review of the scombroid fishes of India. Proc Symp. Scombroid Fishes, Part I. Mar. Biol. Assoc. India, Symp. Ser. 1:1-105.

JORDAN, D. S.

1923. A classification of fishes, including families and genera as far as known. Stanford Univ. Publ., Univ. Ser., Biol. Sci. 3:7T-243.

JORDAN, D. S., and B. W. EVERMANN.

1896. The fishes of north and middle America. U.S. Natl. Mus. Bull. 47:867.

1905. The aquatic resources of the Hawaiian Islands. Part I.-The shore fishes. Bull. U.S. Fish Comm., 1903, 23:170-171.

JORDAN, D. S., and C. H. GILBERT.

1882. Synopsis of the fishes of North America. U.S. Natl. Mus. Bull. 16, $1018 \mathrm{p}$.

JORDAN, D. S., and A. SEALE.

1906. The fishes of Samoa. Description of the species found in the archipelago, with a provisional check-list of the fishes of Oceania. Bull. [U.S.] Bur. Fish. 25:173-455.

JUNE, F. C.

1953. Spawning of yellowfin tuna in Hawaiian waters. U.S. Fish Wildl. Serv., Fish. Bull. 54:47-64.

KASANOVA, I. I.

1962. Tuna larvae of the tropical zone of the Atlantic Ocean. [In Russ.] Vopr. Ikhtiol. 24(3):452-462. [Translated by Kr. Fr. Wiborg; Engl. transl. available U.S. Dep. Commer., Off. Int. Fish.. Wash., D.C.]

KING, J. E., and I. I. IKEHARA.

1956. Comparative study of food of bigeye and yellowfin tuna in the central Pacific. U.S. Fish Wildl. Serv., Fish. Bull. 57:61-85.

KINKI UNIVERSITY FISHERY EXPERIMENTAL STATION

1974. Artificial fertilization and rearing experiments conducted on tunas in 1973-A progress report. Preliminary progress report prepared for a special meeting of cooperating agencies working on tune culture research, 26 February 1974. Kinki Univ. Fish. Exp. Stn. 
Shimizu, 23 p. (Mimeogr.) [Engl. transl. by T. Otsu, 1974, 18 p., transl. No. 3; available Southwest Fish. Cent., Natl. Mar. Fish. Serv., NOAA, Honolulu, HI 96812.]

KISHINOUYE, K.

1915. A study of the mackerels, cybiids, and tunas. [In Jpn.] Suisan Gakkai Hō 1:1-24. [Engl. transl. by W. G. Van Campen, 1950, U.S. Fish Wildl. Serv., Spec. Sci. Rep. Fish. 24, 14 p.]

1917. The food of tunas. [In Jpn.] Suisan Gakkai Hō 2:106108. [Engl. transl. by W. G. Van Campen, 1949, 3 p., transl. No. 29; available Southwest Fish. Cent., Natl. Mar. Fish. Serv., NOAA, Honolulu, HI 96812.]

1923. Contributions to the comparative study of the so-called scombroid fishes. J. Coll. Agric., Imp. Univ., Tokyo 8:293475 .

1924. Observations on the skipjack fishing grounds. [In Jpn.] Suisan Gakkai Hō 4:87-92. [Engl. transl. by W. G. Van Campen. 1950. Larval and juvenile tunas and skipjacks. U.S. Fish. Wildl. Serv., Spec. Sci. Rep. Fish. 19:12-14.]

KLAWE, W. L

1961. Young scombroids from the waters between Cape Hatteras and Bahama Islands. Bull. Mar. Sci. Gulf Caribb. 11:150-157.

1963. Observations on the spawning of four species of tuna (Neothunnus macropterus, Katsuwonus pelamis, Auxis thazard and Euthynnus lineatus) in the eastern Pacific Ocean, based on the distribution of their larvae and juveniles. Inter-Am. Trop. Tuna Comm. Bull. 6:447-540.

1977. What is a tuna? Mar. Fish. Rev. 39(11):1-5.

KLAWE, W. L., I. BARRETT, and B. M. HILLSDON KLAWE

1963. Haemoglobin content of the blood of six species of scombroid fishes. Nature (Lond.) 198:96.

KLAWE, W. L., J. J. PELLA, and W. S. LEET.

1970. The distribution, abundance and ecology of larval tunas from the entrance to the Gulf of California. Inter-Am. Trop. Tuna Comm. Bull. 14:507-544.

KLAWE, W. L., and B. M. SHIMADA

1959. Young scombroid fishes from the Gulf of Mexico. Bull. Mar. Sci. Gulf Caribb. 9:100-115.

KRUMHOLZ, L. A., and D. P. de SYLVA.

1958. Some foods of marlins near Bimini, Bahamas. In On the biology of the Atlantic marlins, Makaira ampla (Poey) and Makaira albida (Poey). Bull. Am. Mus. Nat. Hist. 114:406-411.

KUMARAN, M.

1964. Studies on the food of Euthynnus affinis aftinis (Cantor), Auxis thazard (Lacépède), Auxis thynnoides Bleeker and Sarda orientalis (Temminck and Schlegel). Proc. Symp. Scombroid Fishes, Part II. Mar. Biol. Assoc. India, Symp. Ser. 1:599-606.

KUME, S.

1973. Tuna resources in the South China Sea. S. China Sea Fish. Develop. Coord. Programme, Indo-Pac. Fish. Counc., SCS/DEV/73/4/Rome, 18 p.

LACEPEDE, B. G. E.

1802. Histoire naturelle des poissons. Paris, Plassan. 3, 558 p.

LAEVASTU, T., and H. ROSA, JR

1963. Distribution and relative abundance of tunas in relation to their environment. FAO Fish. Rep. 6:1835-1851.

LAMBOEUF, M.

1972. Tuna fisheries in Morocco. International Commission for the Conservation of Atlantic Tunas. Report for biennial period, 1970-71. Part III:176-180, Madrid.

1973. Status of tuna fisheries and research program in Morocco. International Commission for the Conservation of Atlantic Tunas. Report for biennial period, 1972-73. Part I:140-145, Madrid.

LENARZ, W. H.

1974. Length-weight relations for five eastern tropical AtIantic scombrids. Fish. Bull., U.S. 72:848-851.

LEWIS, A. G.

1967. Copepod crustaceans parasitic on teleost fishes of the Hawaiian Islands. Proc. U.S. Natl. Mus. 121(3574):1-204.

LINTON, E.

1940. Trematodes from fishes mainly from the Woods Hole region,

Massachusets. Proc. U.S. Natl. Mus. 88(3078):1-172.
LOPEZ. R. B.

1961. La presencia del Auxis thazard en Mar del Plata (Teleostomi, Thunnidae). Actas Trab. I. Congr. Sudamer. Zool. 4:91-98.

LORD, C. E

1927. A list of the fishes of Tasmania. J. Pan-Pac. Res. Inst. 2(4):11-16

MacCALLUM, G. A., and W. G. MacCALLUM.

1916. The family Koellikeriadae (Didymozoidae Mont.). Zool. Jahrb. Abt. Syst., Geogr. BioI. Tiere 39:141-168.

MAGNUSON, J. J., and J. G. HEITZ.

1971. Gill raker apparatus and food selectivity among mackerels, tunas, and dolphins. Fish. Bull., U.S. 69:361-370.

MAHDI, N

1971. Additions to the marine fish fauna of Iraq. Iraq Nat. Hist. Mus. Publ. 28, 47 p.

MAKINODAN, Y., and S. IKEDA.

1969. Studies on fish muscle protease-I. On the existence of two kinds of proteinases active in acid and in slightly alkaline $\mathrm{pH}$ range. Bull. Jpn. Soc. Fish. 35:672-676.

MAMAEV, Yu. L.

1968. Helminths of tunas of the South China Sea. [In Russ.] Izv. Acad. Nauk, SSSR, p. 5-27.

MANTER, H. W.

1940. The geographical distribution of digenetic trematodes of marine fishes of the tropical American Pacific. Allan Hancock Pac. Exped. 2:531-547.

1947. The digenetic trematodes of marine fishes of Tortugas, Florida. Am. Midl. Nat. 38:257-416.

1954. Trematoda of the Gulf of Mexico. In P. S. Galtsoff (coordinator), Gulf of Mexico, its origin, waters, and marine life, p. 335-350. U.S. Fish Wildl. Serv., Fish. Bull. 55.

MATHER, F. J., III, and R. H. GIBBS, JR.

1957. Distributional records of fishes from waters off New England and the middle Atlantic states. Copeia 1957:242-244.

MATSUMOTO, W. M.

1958. Description and distribution of larvae of four species of tuna in central Pacific waters. U.S. Fish Wildl. Serv., Fish. Bull. 58:31-72.

1959. Descriptions of Euthynnus and Auxis larvae from the Pacific and Atlantic Oceans and adjacent seas. Dana Rep. 50, 34 p.

1960a. Notes on the Hawaiian frigate mackerel of the genus Auxis. Pac. Sci. 14:173-177.

$1960 \mathrm{~b}$. The application of paper chromatography in identifying tuna larvae. U.S. Fish Wildl. Serv., Spec. Sci. Rep. Fish. 337, 9 p.

1962. Collection and descriptions of juvenile tunas from the central Pacific. Deep-Sea Res. 8:279-286.

MATTHEWS, F. D., D. M. DAMKAER, L. W. KNAPP, and B. B. COLLETTE.

1977. Food of western North Atlantic tunas (Thunnus) and lancetfishes (Alepisaurus). U.S. Dep. Commer., NOAA Tech. Rep. NMFS SSRF-706, 19 p.

MAYO, C. A

1973. Rearing, growth, and development of the eggs and larvae of seven scombrid fishes from the Straits of FIorida. Ph.D. Thesis, Univ. Miami, 138 p.

MEAD, G. W.

1951. PostlarvaI Neothunnus macropterus, Auxis thazard, and Euthynnus lineatus from the Pacific coast of Central America. U.S. Fish Wildl. Serv., Fish. Bull. 52:121-127.

MITO, S.

1961. Pelagic fish eggs and larvae from Japanese waters-II. Lamprida, Zeida, Mugilina, Scombrina, Čarangina and Stromateina. [In Jpn., EngI. resumé.] Sci. Bull. Fac. Agric. Kyushu Univ. 18:451-466.

MIYAKE, M., and S. HAYASI

1972. Field manual for statistics and sampling of Atlantic tunas and tuna-like fishes. InternationaI Commission for the Conservation of AtIantic Tunas. Part III:29-32.

MORIO, T., and A. SUZUKI.

1959. Biochemical studies on the growth and maturation of fish bodies. XI. The contents of molybdenum and nickeI in the livers of tunas and marlins. [In Jpn., Engl. summ.] Rep. Nankai Reg Fish. Res. Lab. 11:32-40. 
NIORITA, M.

1972. Investigation of frigate mackerel (Auxis rochei). [In Jpn.] Rep. Kochi Pref. Fish. Exp. Stn. 68:2-15. [Unedited Engl. transl. in files of Southwest Fish. Cent., Natl. Mar. Fish. Serv., NOAA, Honolulu, HI 96812.]

NAIR, R. V., K. V. RAO, and K. DORAIRAJ.

1970. The tunas and tuna-like fishes of India. Bull. Cent. Mar. Fish. Res. Inst. 23, 93 p.

NAKAMURA, E. L., and J. J. MAGNUSON.

1965. Coloration of the scombrid fish Euthynnus affinis (Cantor). Copeia 1965:234-235.

NAKAMURA, E. L., and W. M. MATSUMOTO.

1967. Distribution of larval tunas in Marquesan waters. U.S. Fish Wildl. Serv., Fish. Bull. 66:1-12.

NAKAMURA, $\mathrm{H}$.

1936. The food habit of yellowfin tuna Neothunnus macropterus (Schlegel) from the Celebes Sea. [In Jpn.] Trans. Nat. Hist. Soc., Formosa 26(148):1-8. [Engl. Trans. by W. G. Van Campen. 1950. The food habits of the yellowfin tuna (Neothunnus). U.S. Fish Wildl. Serv., Spec. Sci. Rep. Fish. 23, 8 p.]

1938. Report of an investigation of the spearfishes of Formosan waters. [In Jpn.] Rep. Taiwan Gov., Gen. Fish. Exp. Stn. 10:134. [Engl. transl. by W. G. Van Campen, 1955, U.S. Fish Wildl. Serv., Spec. Sci. Rep. Fish. 153, 46 p.]

1942. On the ecology of the istiophorid fishes of Taiwan waters. [In Jpn.] Suisan Gakkai Hō 9:45-51.

NIWA, H., T. TAMURA, and I. HANYU.

1975. Spectral sensitivity curves of the skipjack tuna and the frigate mackerel. [In Engl.] Bull. Jpn. Soc. Sci. Fish. 41:923-927.

OKACHI, l.

1958. Studies on the distribution and structure of the fish fauna in the Japan Sea by catch statistics-I. Seasonal distribution and fishing condition of the fishes in the Tsushima warm current system. Annu. Rep. Jpn. Sea Reg. Fish. Res. Lab. 4:1-13.

OKADA, Y.

1955. Fishes of Japan. Maruzen Co., Ltd., Tokyo, 462 p.

PERRIN, W. F., R. R. WARNER, C. H. FISCUS, and D. B. HOLTS. 1973. Stomach contents of porpoise, Stenella spp., and yellowfin tuna. Thunnus albacares, in mixed-species aggregations. Fish. Bull., U.S. 71:1077-1092.

PHILIPPINE BUREAU OF FISHERIES.

1973. Country report - Philippines. Technical seminar on South China Sea fisheries resources. Southeast Asian Fisheries Development Center, Bangkok. Thailand, 21-25 May 1973. SEAFDEC/SCS 73:S-23, 31 p.

PILLAI, N. K.

1967. Copepods parasitic on Indian marine fishes-a review. Proc. Symp. Crustacea, Part 5. Mar. Biol. Assoc. India, Symp. Ser. $2: 1556-1680$.

POSTEL, E.

1964. Les thonides d'Afrique du Nord. Proc. Symp. Scombroid Fishes, Part I. Mar. Biol. Assoc. India, Symp. Ser. 1:211-220.

POTTHOFF, T., and W. J. RICHARDS.

1970. Juvenile bluefin tuna, Thunnus thynnus (Linnaeus), and other scombrids taken by terns in the Dry Tortugas, Florida. Bull. Mar. Sci. 20:389-413.

RABINDRA NATH, P.

1962. Feeding habits and seasonal distribution of the frigate mackeral, Auxis thazard (Lacèpede). (Abstr.) Proc. First AllIndia Congr. Zool. 1959, Part 3:6.

RADOVICH, J.

1961. Relationships of some marine organisms of the northeast $\mathrm{Pa}$ cific to water temperatures particularly during 1957 through 1959. Calif. Dep. Fish Game, Fish. Bull. 112, 62 p.

RAE, B. B.

1963. Rare fish. Scott. Fish. Bull. 19:26.

RAFINESQUE, C. S.

1810. Caratteri di alcuni nuovi generi e nuove specie d'animali e piante della Sicilia. San Filippo, Palermo, 105 p.

RAO, K. V. N.

1964. An account of the ripe ovaries of some Indian tunas. Proc. Symp. Scombroid Fishes, Part II. Mar. Biol. Assoc. India, Symp. Ser. 1:733-743.
RAWLINGS, J. E.

1953. A report on the Cuban tuna fishery. Commer. Fish. Rev. 15(1):8-21.

RICHARDS, W. J.

1969. Distribution and relative apparent abundance of larval tunas collected in the tropical Atlantic during Equalant surveys I and II. In Proceedings of the Symposium on the Oceanography and Fisheries Resources of the Tropical AtIantic, p. 289-315. UNESCO, Paris.

RICHARDS, W. J., and G. R. DOVE.

1971. Internal development of young tunas of the genera Katsuwonus, Euthynnus, Auxis, and Thunnus (Pisces, Scombridae). Copeia 1971:72-78.

RICHARDS, W. J., and J. E. RANDALL.

1967. First Atlantic records of the narrow-corseleted frigate mackerel, Auxis thazard. Copeia 1967:245-247.

RICHARDS, W. J., and D. C. SIMMONS.

1971. Distribution of tuna larvae (Pisces, Scombridae) in the northwestern Gulf of Guinea and off Sierra Leone. Fish. Bull., U.S. 69:555-568.

RISSO, A.

1810. Ichthyologie de Nice ou histoire naturelle des poissons du département des Alpes Maritimes. F. Schoell, Paris, 388 p.

1826. Histoire naturelle des poissons de la Méditerranée qui fréquentent less côtes des Alpes Maritimes, et qui vivent dans le Golfe de Nice. In Histoire naturelle des principales productions de l'Europe méridionale, 3:97-480. Levrault, Paris and Strasbourg.

RIVAS, L. R.

1951. A Preliminary review of the western North Atlantic fishes of the family Scombridae. Bull. Mar. Sci. Gulf Caribb. 1:209-230.

ROBERTS, P. E., D. EGGLESTON, and G. D. JAMES.

1977. Frigate tuna Auxis thazard in New Zealand waters. N.Z. J. Mar. Freshwater Res. 11:163-167.

RODRIGUEZ-RODA, J.

1966. Estudio de la bacoreta, Euthynnus a'lleteratus (Raf.), bonito, Sarda sarda (Bloch) y melva, Auxis thazard (Lac.), capturados por las almadrabas españolas. [In Span., Engl. surnm.] Invest. Pesq. 30:247-292.

1967. La bacoreta, el bonito y la melva, de las almadrabas españolas. Publ. Tech. Junta Estud. Pesca 6:235-245.

RONQUILLO, I. A.

1954. Food habits of tunas and dolphins based upon the examination of their stomach contents. Philipp. J. Fish. 2:71-83.

ROSA, H., JR.

1950. Scientific and common names applied to tunas, mackerels and spear fishes of the world with notes on their geographic distribution. FAO, Wash., D.C., 235 p.

ROSE, C. D., and W. W. HASSLER.

1974. Food habits and sex ratios of dolphin Coryphaena hippurus captured in the western Atlantic Ocean off Hatteras, North Carolina. Trans. Am. Fish. Soc. 103:94-100.

ROUNSEFELL, G. A., and W. H. EVERHART.

1953. Fishery science-its methods and applications. John Wiley \& Sons, Inc., N.Y., 444 p.

ROYCE, W. F.

1957. Observations on the spearfishes of the central Pacific. U.S. Fish Wildl. Serv., Fish. Bull. 57:497-554.

SAUNDERS, D. C.

1966. Differential blood cell counts of 121 species of marine fishes of Puerto Rico. Trans. Am. Microsc. Soc. 85:427-449.

SCHAEFER, M. B., and J. C. MARR.

1948. Juvenile Euthynnus lineatus and Auxis thazard from the Pacific Ocean off Central America. Pac. Sci. 2:262-271.

SCOTT, T. D.

1962. The marine and fresh water fishes of South Australia. W. L. Hawes, Gov. Printer, Adelaide, 338 p.

SERVENTY, D. L.

1941. The Australian tunas. Counc. Sci. Ind. Res., Div. Fish. Rep. $4,48 \mathrm{p}$.

SHARP, G. D., and S. PIRAGES.

1978. Ill. The distribution of red and white swimming muscles, their biochemistry, and the biochemical phylogeny of selected scombrid fishes. In G. D. Sharp and A. E. Dizon (editors), The physiological ecology of tunas, p. 41.78. Acad. Press, N.Y. 
SHOMURA, R. S,

1966. The Atlantic tuna fisheries, 1963. Commer. Fish. Rev. $28(5): 1-11$

SILAS, E. G.

1967a. Parasites of scombroid fishes. Part I. Mongenetic trematodes, digenetic trematodes, and cestodes. Proc. Symp. Scombroid Fishes, Part III. Mar. Biol. Assoc. India, Symp. Ser. 1:799-875.

1967b. Tuna fishery of the Tinnevelly Coast, Gulf of Mannar. Proc. Symp. Scombroid Fishes, Part III. Mar. Biol. Assoc. India, Symp. Ser. 1:1083-1118

1969. Exploratory fishing by R. V. Varuna. Bull. Cent. Mar. Fish. Res. Inst. 12, $86 \mathrm{p}$.

SILAS, E. G., and A. N. P. UMMERKUTTY.

1967. Parasites of scombroid fishes. Part II. Parasitic Copepoda. Proc. Symp. Scombroid Fishes, Part III. Mar. Biol. Assoc. India, Symp. Ser. 1:876-993.

SIVASUBRAMANIAM, $\mathrm{K}$.

1965. Exploitation of tunas in Ceylon's coastal waters. Bull. Fish. Res. Stn., Ceylon 18:59-73.

1966. Distribution and length-weight relationships of tunas and tuna-like fishes around Ceylon. Bull. Fish. Res. Stn., Ceylon $19: 27-46$.

1973. Co-occurrence and the relative abundance of narrow and broad corseletted frigate mackerels Auxis thazard (Lacepede) and Auxis rochei (Risso), around Ceylon. In Proceedings of the Symposium on Living Resources of the Seas Around India, p. 537-547. Cent. Mar. Fish. Res. Inst., Cochin.

STARKS, E. C.

1910. The osteology and mutual relationships of the fishes belonging to the family Scombridae. J. Morphol. 21:77-99.

STRASBURG, D. W.

1959. An instance of natural mass mortality of larval frigate mackerel in the Hawaiian Islands. J. Cons. 24:255-263.

1960. Estimates of larval tuna abundance in the central Pacific. U.S. Fish Wildl. Serv., Fish. Bull. 60:231-255.

SUZUKI, A., and T. MORIO

1957. Biochemical studies on the growth and maturation of fish bodies. V. The relation between the maturation of "Marusöda", Auxis tapeisoma (Bleeker) and the contents of iron, copper and zinc in their body. [In Jpn., Engl. summ.] Rep. Nankai Reg. Fish. Res. Lab. 6:29-40.

TAKAHASHI, N.

1924. On the order Plecostei established by Dr. Kishinouye. [In Jpn.] Zool. Mag., Tokyo 36(432):397-408. [Engl. transl. by W. G. Van Campen. 1951. Kishinouye's order Plecostei. U.S. Fish Wildl. Serv., Spec. Sci. Rep. Fish. 50, p. 3-16.]

TALBOT, F. H.

1964. The South African tunas. Proc. Symp. Scombroid Fishes, Part I. Mar. Biol. Assoc. India, Symp. Ser. 1:187-209.

TAMURA, T., I. HANYU, and H. NIWA.

1972. Spectral sensitivity and color vision in skipjack tuna and related species. [In Engl.] Bull. Jpn. Soc. Sci. Fish. 38:799802.

TANIGUCHI, N., and Y. KONISHI

1971. Muscle protein polymorphism in frigate mackerel collected from the coastal region of Kochi Pref., Japan [In Engl.] Bull. Jpn. Soc. Sci. Fish. 37:571-576.

TANIGUCHI, N., and I. NAKAMURA.

1970. Comparative electropherograms of two species of frigate mackerel. [In Engl.] Bull. Jpn. Soc. Sci. Fish. 36:173-176.

TESTER, A. L., and E. L. NAKAMURA

1957. Catch rate, size, sex, and food of tunas and other pelagic fishes taken by trolling off Oahu, Hawaii, 1951-55. U.S. Fish Wildl. Serv., Spec. Sci. Rep. Fish. 250, 25 p.

THOMAS, P. T.

1967. Size composition of the oceanic skipjack Katsuwonus pelamis (Linnaeus) and the yellowfin tuna Neothunnus macropterus (Temminck and Schlegel) from the Laccadive Sea around Minicoy during the season 1960-61. Proc. Symp. Scombroid Fishes, Part III. Mar. Biol. Assoc. India, Symp. Ser. 1:1146-1153.

THOMAS, P. T., and M. KUMARAN. 1963. Food of Indian tunas. FAO Fish. Rep. 6:1659-1667.
TIBBO, S. N., and J. S. BECKETT.

1972. Canadian research activities on tunas and tuna-like tishes in the Atlantic Ocean, 1970-71. International Commission for the Conservation of Atlantic Tunas. Report for biennial period, 1970 . 71. Part IIl:148-151.

TORTONESE, E.

1965. La popolazione Mediterranea di Auxis (Pisces Thunnidae) in rapporto alla sistematica del genera. Ann. Mus. Civ. Stor. Nat. Genova 74:140-155.

UCHIDA, R. N

1963. Synopsis of biological data on frigate mackerel Auxis thazard (Lacépède) 1802 (Pacitic Ocean). FAO Fish. Rep. 6:241-273.

UCHIHASHI, $\mathrm{K}$.

1953. Ecological study of the Japanese teleosts in relation to brain morphology. [In Jpn.] Bull. Jpn. Sea Reg. Fish. Res. Lab. 2, 166

UEYANAGI, $\mathrm{S}$

1964. Methods of identification for the young stages of tunas and spearfishes. 1. Methods of identifying larval and post-larval tunas. [In Jpn.] Material for the Tuna Fisheries Research Council, Nankai Reg. Fish. Res. Lab. [Engl. transl. by W. G. Van Campen, 1964, 10 p.; available Southwest Fish. Cent., Natl. Mar. Fish. Serv., NOAA, Honolulu. HI 96812.I

UEYANAGI, S., K. MORI, Y. NISHIKAWA, and A. SUDA

1973. Report on experiments on the development of tuna culturing techniques (April, 1970-March, 1973). [In Jpn., Engl. summ.] Far Seas Fish. Res. Lab., S Ser. 8, 165 p.

VERVOORT, $W$.

1965. Three new species of Bomolochidae (Copepoda, Cyclopoida) from tropical Atlantic tunnies. Zool. Verh. (Leiden) 76:1-40.

WADE, C. B.

1949. Notes on the Philippine frigate mackerels, family Thunnidae, genus Auxis. U.S. Fish Wildl. Serv., Fish. Bull. 51:229-240.

1951. Larvae of tuna and tuna-like fishes from Philippine waters. U.S. Fish Wildl. Serv., Fish. Bull. 51:445-485.

WATANABE, $\mathrm{H}$

1964. Frigate mackerels (genus Auxis) from the stomach contents of tunas and marlins. Proc. Symp. Scombroid Fishes, Part II. Mar. Biol. Assoc. India, Symp. Ser. 1:631-642.

WENT, A. E. J.

1955. The plain bonito, Auxis rochei Risso, and other members of the mackerel family in Irish waters. Ir. Nat. J. 11:339-342.

1956. Recent records of species of fishes rare to Irish coastal waters. Ir. Nat. J. 12:68-70.

1958. Reflections on the "List of Irish fishes (1957)." Ir. Nat. J. 12:255-259.

1967. Rare fishes taken in Irish waters in 1966. Ir. Nat. J. 15:280283.

WENT, A. E. J., and M. KENNEDY.

1969. List of lrish fishes. 2d ed. Natl. Mus., Stationary Office, Dublin, p. 6-44.

WHEELER. A., and R. W. BLACKER.

1969. Rare and little-known fishes in British Seas in 1966 and 1967. J. Fish Biol. 1:311-331.

WHEELER, J. F. G., and F. D. OMMANNEY.

1953. Report on the Mauritius-Seychelles fisheries survey, 19481949. Part IV. General considerations and conclusions. Fish. Publ. (Lond.) 1(3):120-143.

WHITLEY, G. P.

1964. Scombroid fishes of Australia and New Zealand. Proc. Symp. Scombroid Fishes, Part I. Mar. Biol. Assoc. India, Symp. Ser. 1:221-253

WHITNEY, R. R.

1969. Inferences on tuna behavior from data in fishermen's logbooks. Trans. Am. Fish. Soc. 98:77-93.

WILLIAMS, F.

1963. Synopsis of biological data on frigate mackerel Auxis thazard (Lacépède) 1802 (Indian Ocean).

FAO Fish. Rep. 6:157166.

WHSE, J. P., and A. C. JONES.

1971. Tunas and tuna fisheries of the Caribbean region. FAO Fish. Rep. 71.2:331-338. 
YABE, H., and S. UEYANAGI.

1962. Contributions to the study of the early life history of the tunas. [In Engl.] Occas. Rep., Nankai Reg. Fish. Res. Lab. 1:5772.

YABE, H., Y. YABUTA, and S. UEYANAGI.

1963. Comparative distribution of eggs, larvae and adults in relation to biotic and abiotic environmental factors. FAO Fish. Rep. 6:979-1009.

YAMASHIGE, $M$.

1974. Some consideration on forecasting [catches] in the long-corseletted frigate mackerel (A. rochei) fishery off Ashizurimisaki (Cape Ashizure). Relation between fishing or sea conditions in the Izu area and fishing conditions in Kochi Prefecture. [In Jpn.] Rep. Kochi Pref. Fish. Exp. Stn. 70:239-244. [Unedited
Engl. transl. in files of Southwest Fish. Cent., Natl. Mar. Fish. Serv., NOAA, Honolulu, HI 96812.1

YASUI, M

1975. Some observations on the frigate mackerel which migrates into Japanese coastal waters. [In Jpn.] Proceedings of the 1974 Tuna Research Conference, Shimizu, Japan, February 4-6. 1975, p. 219-225. Fish. Agency, Far Seas Fish. Res. Lab.

YOKOTA, T., M. TORIYAMA, F. KANAI, and S. NOMLRA 1961. Studies on the feeding habit of fishes. [In Jpn.] Rep. Nankai Reg. Fish. Res. Lab. 14:1-234.

YOSHIDA, H. O., and E. L. NAKAMURA.

1965. Notes on schooling behavior, spawning, and morphology of Hawaiian frigate mackerels, Auxis thazard and Auxis rochei. Copeia 1965:111-114. 


\section{FISHERIES SYNOPSES}

This series of documents, Issued by FAO, CSIRO, INP, and NMFS, contalns comprehenslve revlews of present knowledge on species and stocks of aquatlc organisms of present or potentlal economlc Interest. The Flshery Resources and Environmient Division of FAO is responsible for the overall coordination of the serles. The prlmary purpose of thls serles is to make exlsting Information readily available to fishery sclentists accordlng to a standard pattern, and by so dolng also to draw attentlon to gaps In knowledge. It Is hoped that synopses in this series will be useful to other scientlsts InItlating Investlgatlons of the specles concerned or of related ones, as a means of exchange of knowledge among those already working on the specles, and as the basis for comparative study of fisherles resources. They will be brought up to date from time to time as further Informatlon becomes available.

The documents of this series are Issued under the following tltles:

$\begin{array}{lll} & & \text { Symbol } \\ \text { FAO } & \text { Flsherles Synopsis No. } & \text { FIR/S } \\ \text { CSIRO } & \text { Flsherles Synopsls No. } & \text { DFO/S } \\ \text { INP } & \text { Sinopsls sobre la Pesca No. } & \text { INP/S } \\ \text { NMFS } & \text { Fisherles Synopsls No. } & \text { NMFS/S }\end{array}$

Synopses in this series are complled according to a standard outllne descrlbed In Flb/S1 Rev. 1 (1965). FAO, CSIRO, INP, and NMFS are working to secure the cooperatlon of other organlzatlons and of Individual sclentlsts In drafting synopses on species about which they have knowledge, and welcome offers of help In this task. Additlons and correctlons to synopses already issued will also be most welcome. Comments on indlvidual synopses and requests for Informatlon should be addressed to the coordinators and editors of the issuing organizations, and suggestlons regarding the expanslon or modification of the outline to FAO:

\section{FAO:}

Fishery Resources and Environment Dlvision Aquatic Resources Survey and Evaluation Service Food and Agriculture Organization of the United Nations Via delle Terme di Caracalla 00100 Rome, Italy

INP:

Instituto Nacional de Pesca

Subsecretaria de Pesca

Secretaria de Pesca

Secretaria de Industria y Comercio

Carmona y Valle 101-403

Mexico 7, D.F.

\section{CSIRO:}

CSIRO Divislon of Flsherles and Oceanography

Box 21

Cronulla, N.S.W. 2230

Australia

NMFS:

Scientlfic Editor

National Marine Flsherles Servlce, NOAA

Auke Bay Fisherles Laboratory

P.O. Box 155

Auke Bay, AK 99821

U.S.A.

Consolidated lists of species or groups covered by synopses issued to date or In preparation will be Issued from time to time. Requests for copies of synopses should be addressed to the Issuing organization; except for NMFS/S coples, these can be purchased from National Technical Information Service, U.S. Department of Commerce, 5285 Port Royal Road, Springfleld, VA 22151.

The following synopses in this series have been issued since January 1978:

NMFS/S 116 NMFS/S 117

NMFS/S 123 NMFS/S 118 NMFS/S 122 NMFS/S 121
Synopsis of biologlcal data on the red porgy, Pagrus pagrus (Linnaeus) Synopsis of biologlcal data for the winter flounder, Pseudopleuronectes americanus (Walbaum)

Synopsis of blologlcal data on the rock crab, Cancer irroratus Say

Synopsis of biological data on bonitos of the genus Sarda

Synopsls of biologlcal data on tunas of the genus Euthynnus

Synopsis of biological data on striped bass, Morone sexatilis (Walbaum)
May 1978

November 1978

May 1979

May 1980

October 1979

June 1980 


\section{UNITED STATES}

DEPARTMENT OF COMMERCE

NATIONAL OCEANIC AND ATMOSPHERIC ADMINISTRATION

NATIONAL MARINE FISHERIES SERVICE

SCIENTIFIC PUBLICATIONS STAFF

1700 WESTLAKE AVE. N., ROOM 336

SEATTLE, WA 98109

OFFICIAL BUSINESS
PENN STATE UNIVERSITY LIBRARIES

II

POSIAGE AND FEES PAID US DEPARTMENT OF COMMERCE $\operatorname{COM} 210$

THIRD CLASS BULK RATE

\section{NOAA SCIENTIFIC AND TECHNICAL PUBLICATIONS}

The National Oceanic and Aimospheric Administration was cstablished as part of the Department of Commeree on October 3. 1970. The nission responsibilitice of NOAA are to assess the sociocconnmic impact of natural and technological changes in the environment and to monitor and predict the state of the solid Earth, the occans and their living resources, the atmosphere, ind the space environment of the Earth

The major components of NOAA regularly producc various types of scientific and technical information in the following kinds of publications:

PROFESSIONAI. P.APERS - Important definitive research results, major techniques, and special investigations.

CONTRACT AND GRANT REPORTS - Rcports prepared by contractors or grantces under NOAA sponsorship.

ATLAS - Presentation of analyzed data gencrally in the form of maps showing distribution of rainfall. chemical and physical conditions of occans and atmosphere, distribution of fishes and marine mammals, ionospheric conditions, ctc.
TECHNICAI. SERIICE PUBLICATIONS - Reports comtaining dilta. observations, instructions, etc. A partial listing includes data serials; prediction and nutlook periodicils; technical manuals. training papers, planning reports, and information serials; and miscellancous technical publications.

TECHNICAL REPORTS - Journal quality with extensive details, mathematical developments, or data listings.

TECHNICAL MEMORANDUMS - Reports of prcliminary, partial, or negative rescarch or technology results, interim instructions, and the like.

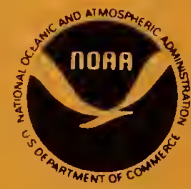

Information on availability of NOAA publications can be obfained from:

ENVIRONMENTAL SCIENCE INFORMATION CENTER (D822)

ENVIRONMENTAL DATA AND INFORMATION SERVICE

NATIONAL OCEANIC AND ATMOSPHERIC ADMINISTRATION

U.S. DEPARTMENT OF COMMERCE

6009 Executive Boulevard

Rockville, MD 20852 